\title{
Naar een HRM portfolio : Universiteit Maastricht
}

\author{
Citation for published version (APA):
}

de Grip, A., Kriechel, B., Sieben, I. J. P., \& Smits, W. (2006). Naar een HRM portfolio : Universiteit

Maastricht. Researchcentrum voor Onderwijs en Arbeidsmarkt, Faculteit der Economische

Wetenschappen. ROA Reports No. 4 https://doi.org/10.26481/umarep.2006004

Document status and date:

Published: 01/01/2006

DOI:

10.26481/umarep.2006004

Document Version:

Publisher's PDF, also known as Version of record

\section{Please check the document version of this publication:}

- A submitted manuscript is the version of the article upon submission and before peer-review. There can be important differences between the submitted version and the official published version of record.

People interested in the research are advised to contact the author for the final version of the publication, or visit the DOI to the publisher's website.

- The final author version and the galley proof are versions of the publication after peer review.

- The final published version features the final layout of the paper including the volume, issue and page numbers.

Link to publication

\footnotetext{
General rights rights.

- You may freely distribute the URL identifying the publication in the public portal. please follow below link for the End User Agreement:

www.umlib.nl/taverne-license

Take down policy

If you believe that this document breaches copyright please contact us at:

repository@maastrichtuniversity.nl

providing details and we will investigate your claim.
}

Copyright and moral rights for the publications made accessible in the public portal are retained by the authors and/or other copyright owners and it is a condition of accessing publications that users recognise and abide by the legal requirements associated with these

- Users may download and print one copy of any publication from the public portal for the purpose of private study or research.

- You may not further distribute the material or use it for any profit-making activity or commercial gain

If the publication is distributed under the terms of Article $25 \mathrm{fa}$ of the Dutch Copyright Act, indicated by the "Taverne" license above, 


\section{Naar een HRM Portfolio Universiteit Maastricht}

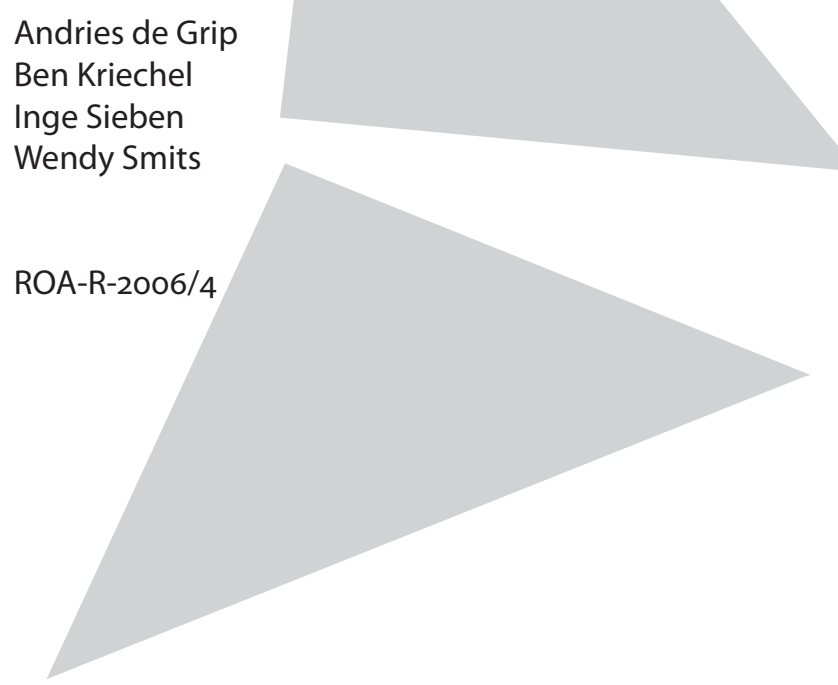




\section{Colofon}

(C) Researchcentrum voor Onderwijs en Arbeidsmarkt. Niets uit deze uitgave mag op enige manier worden verveelvoudigd zonder voorafgaande schriftelijke toestemming van de directeur van het ROA.

\section{Researchcentrum voor Onderwijs en Arbeidsmarkt}

Faculteit der Economische Wetenschappen en Bedrijfskunde

Universiteit Maastricht

\section{Vormgeving}

ROA secretariaat, Maastricht

\section{Verkoop}

Researchcentrum voor Onderwijs en Arbeidsmarkt

email: secretary@roa.unimaas.nl

website: www.roa.unimaas.nl

ISBN-IO: 90-532I-433-X

ISBN-I3: 978-90-532I-433-6

april 2006 


\section{Inhoud}

Voorwoord

Management samenvatting vii

1 Inleiding 1

1.1 Inleiding 1

2 Het HRM beleid in faculteiten en ondersteunende diensten 5

2.1 Inleiding 5

2.2 Faculteiten $\quad 5$

$\begin{array}{lll}2.3 \text { Servicecentra } & 20\end{array}$

3 Inventarisatie van de beschikbare data $\quad 27$

$\begin{array}{ll}3.1 \text { Data beschikbaar op centraal niveau } & 27\end{array}$

3.2 Beschikbare informatie bij faculteiten en ondersteunende diensten $\quad 30$

4 Enquête onder beherend bazen 31

5 Beschikbare Human Resources 35

5.1 Inleiding 35

5.2 Functies binnen de capaciteitsgroepen en de ondersteunende diensten 36

5.3 Werkervaring en aard dienstverband van medewerkers 39

5.4 Vergrijzing en emancipatie 43

$\begin{array}{ll}5.5 & \text { Internationalisering } \\ 5.6 & \text { Ziekteverzuim }\end{array}$

$\begin{array}{ll}5.6 \text { Ziekteverzuim } & 48\end{array}$

5.7 Samenvatting: indicatoren voor de HRM portfolio 48

6 Instroom, uitstroom en interne doorstroom 51

6.1 De instroom en uitstroom en personeel $\quad 51$

6.2 De interne doorstroom van medewerkers $\quad 54$

6.3 Interne promotie of extern werven van wetenschappelijke staf 62

6.4 Samenvatting: indicatoren voor de HRM portfolio 63

7 HRM beleid $\quad 65$

7.1 Beherend bazen van capaciteitsgroepen en ondersteunende diensten 66

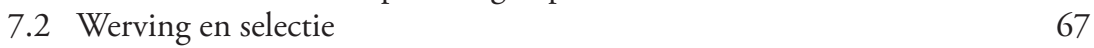


7.3 Arbeidsvoorwaardenbeleid voor medewerkers

7.4 Personeelsontwikkelingsbeleid 7

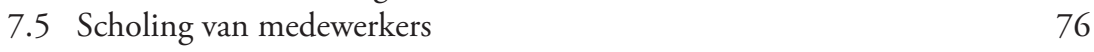

7.6 Ervaren belemmeringen bij personeelsbeleid 79

7.7 Samenvatting: indicatoren voor de HRM portfolio 79

8 Prestatiemaatstaven $\quad 83$

$\begin{array}{ll}8.1 \text { Onderwijsperformance } & 84\end{array}$

$\begin{array}{ll}8.2 \text { Onderzoeksperformance } & 92\end{array}$

8.3 Samenvatting: Indicatoren voor de HRM-portfolio 97

Bijlage I Eerste invulling HRM Portfolio UM 99

Bijlage II Vragenlijsten enquêtes onder de beherend bazen van de capaciteitsgroepen en de ondersteunende diensten 


\section{Voorwoord}

In opdracht van de Stuurgroep HRM van de Universiteit Maastricht heeft het ROA een verkennende studie gedaan naar de mogelijke invulling van een HRM portfolio, waarin de ontwikkeling van beschikbare human resources, het gevoerde HRM beleid en verschillende performance indicatoren in kaart worden gebracht. Bij het opstellen van deze HRM portfolio voor de Universiteit Maastricht is zoveel mogelijk gebruik gemaakt van de informatie die binnen de instelling reeds beschikbaar is. Op grond van deze informatie zijn voor de verschillende onderdelen van de HRM portfolio enkele kernindicatoren geconstrueerd, die in dit rapport worden gepresenteerd.

Flycatcher Internet research verzorgde de enquête onder de leidinggevenden. Onze dank gaat uit naar de Stuurgroep HRM, onder leiding van respectievelijk Dr. Anne Flierman en Drs. André Postema, die dit project heeft begeleid. Drs. Rina van den Brandt, Drs. Michiel Foppen Prof. dr. Gerjo Kok en Mr. Appie Leurmans droegen daarbij zorg voor de directe begeleiding. Verder gaat onze dank uit naar Dr. Lex Borghans, Prof. dr. Hans Heijke, Prof. dr. Anita Jansen, Prof. dr. Robert Roe, Ann Spaas, Ir. Peter Thuis en Janny de Vries, die ons waardevolle adviezen gaven voor de vragenlijst die is voorgelegd aan de leidinggevenden. 


\section{Management samenvatting}

Algemeen

- Er bestaat een grote diversiteit van strategieën met betrekking tot het personeelsbeleid tussen de faculteiten en de ondersteunende diensten van de UM.

- De servicecentra zijn bezig zich te heroriënteren omdat zij te maken hebben met directere methoden van afrekenen. Hierdoor wordt gezocht naar een meer bedrijfsmatige aanpak.

- Bijlage I geeft een overzicht van de HRM portfolio's voor de UM en de verschillende faculteiten en ondersteunende diensten. Deze indicatoren bieden de bouwstenen voor een planning-en-control cyclus met betrekking tot het HRM.

\section{Beschikbare data}

- Het op centraal niveau beschikbare SAP informatiesysteem biedt mogelijkheden om inzicht te krijgen in de beschikbare human resources en de interne mobiliteit van het personeel. Het bestaande SAP systeem heeft de potentie om zich te ontwikkelen tot het centrale managementinformatiesysteem voor het HRM beleid van de UM. Om dit te realiseren zal een aantal stappen moeten worden gezet, gericht op:

- - het verbeteren van de kwaliteit van de reeds beschikbare data;

- het verbeteren van de gebruikswaarde van de reeds beschikbare data;

- het opnemen van data met betrekking tot de personeelsontwikkeling en het gevoerde HRM beleid.

- Het METIS systeem van de universiteitsbibliotheek geeft op centraal niveau vergelijkbare informatie over de onderzoeksprestaties van de verschillende faculteiten en capaciteitsgroepen. Het METIS systeem geeft echter onvoldoende inzicht in de kwaliteit van wetenschappelijke publicaties, terwijl dit voor de meeste faculteiten juist steeds belangrijker wordt. Op meerdere faculteiten wordt de onderzoeksoutput ook structureel gemeten. Daarbij wordt wel sterk gelet op de kwaliteit van de tijdschriften waarin wordt gepubliceerd. Meestal gebeurt dit op basis van de "impact factor" van de tijdschriften. 
- Over het arbeidsvoorwaardenbeleid is weinig informatie op centraal niveau beschikbaar. Zo is niet bekend hoeveel medewerkers gebruik maken van de aangeboden secundaire arbeidsvoorwaarden en het keuzemodel arbeidsvoorwaarden UM.

- Ook is er vrijwel geen informatie beschikbaar over het binnen faculteiten en ondersteunende diensten gevoerde HRM beleid. Om deze lacune op te vullen is er een enquête gehouden onder de beherende bazen van capaciteitsgroepen en ondersteunende diensten. Vanwege de geringe respons op deze enquête is het helaas niet mogelijk de uitkomsten van de enquête te verbijzonderen naar de verschillende faculteiten en ondersteunende diensten.

- Met betrekking tot de onderwijsprestaties van de verschillende faculteiten is er op centraal niveau met name informatie beschikbaar over de ontwikkeling van studentenaantallen en het studierendement. Op faculteitair niveau wordt er structureel informatie verzameld op basis van de onderwijsevaluaties. Deze informatie verschilt echter tussen de faculteiten in zowel vorm als inhoud. Er was bij de meeste faculteiten echter grote terughoudendheid om onderwijs- en onderzoeksprestaties ter beschikking te stellen voor de HRM portfolio. Alleen de economisch faculteit heeft deze informatie beschikbaar willen stellen.

- In het kader van het INK project is gezocht naar adequate prestatiemaatstaven voor de ondersteunende diensten. De prestatiemeting wordt daarbij met name geoperationaliseerd door het in kaart brengen van de waardering voor de geleverde diensten bij UM medewerkers en studenten. Om dergelijke subjectieve indicatoren adequaat in te kunnen vaststellen is echter een representatieve respons vereist onder de potentiële gebruikers van de verschillende diensten.

\section{Beschikbare human resources}

- De helft van alle medewerkers die bij de UM werkzaam zijn, bestaat uit wetenschappelijk personeel. Dit is iets minder dan het landelijke gemiddelde. Vanzelfsprekend is het percentage WP'ers in de capaciteitsgroepen (78\%) veel hoger dan bij de ondersteunende diensten (7\%). De verhouding tussen WP en OBP is de afgelopen vijf jaar veranderd: in de capaciteitsgroepen is het percentage WP'ers met 9 procentpunt toegenomen, terwijl er bij de ondersteunende diensten - relatief gezien - juist minder WP'ers zijn gaan werken.

- Het WP is gemiddeld genomen ruim acht jaar in dienst van de UM, terwijl het OBP ruim elf jaar bij de universiteit werkzaam is. De personeelsopbouw van het wetenschappelijk personeel laat een duidelijk duaal karakter zien met aan de ene kant veel onervaren medewerkers ( $52 \%$ van de WP'ers is minder dan twee jaar in dienst) en aan de andere kant medewerkers die lange tijd bij de universiteit in dienst zijn (30\% is langer dan tien jaar bij de UM werkzaam). De eerste groep zorgt voor de nodige vernieuwing in de universiteit,maar is ook onervaren, terwijl de laatste groep het risico loopt op ervaringsconcentratie en een verlies aan inzetbaarheid. 
- Er is sprake van een toenemende vergrijzing van het personeelsbestand van de UM. Het percentage medewerkers dat ouder is dan 55 jaar is in vijf jaar tijd bijna verdubbeld tot zo'n I2\%. De gemiddelde leeftijd van WP'ers is 39 jaar. Het OBP is met gemiddeld 42 jaar over het algemeen genomen wat ouder.

- Van het WP is $42 \%$ vrouw. Ten opzichte van 2000 , toen nog slechts eenderde van het WP vrouw was, is dit percentage flink toegenomen. Wel blijkt dat het aantal vrouwen duidelijk afneemt met de hoogte van de functie. Van de hoogleraren is slechts $3 \%$ vrouw, terwijl een kwart van de universitair hoofddocenten en eenderde van de universitair docenten vrouw is. Bij het OBP is de meerderheid vrouw. Al met al springt de UM boven de andere universiteiten uit. Landelijk is $4 \mathrm{I} \%$ van het personeel dat werkzaam is bij universiteiten vrouw, terwijl dit percentage bij de UM op $52 \%$ ligt.

- De UM is een internationaal georiënteerde universiteit. Zo heeft $20 \%$ van de WP'ers in de capaciteitsgroepen een niet-Nederlandse nationaliteit. Het gaat dan met name om Belgen, Duitsers, Britten, Amerikanen, Italianen, Polen, Russen, Fransen en Chinezen. In 2000 lag het percentage niet-Nederlandse WP'ers nog op I2\%. Van het OBP is 6\% van buitenlandse afkomst.

- De groei de werkgelegenheid bij de UM de afgelopen jaren afgenomen. Terwijl het aantal mensen dat bij de UM werkt in 2000 nog toenam met $5,6 \%$, is er in 2004 zelfs sprake geweest van een lichte daling van de personeelsomvang met $0,3 \%$. De instroom van nieuw personeel is dan ook sterk afgenomen van $19,7 \%$ in 2000 naar $13,5 \%$ in 2004 . Daarentegen is de personeelsuitstroom de afgelopen jaren vrijwel niet beïnvloed door de minder gunstige werkgelegenheidsontwikkeling.

- Onder de medewerkers die nog maar kort bij de UM werkzaam zijn, is de uitstroom relatief hoog. Van degenen die in 2000 bij de UM zijn gaan werken is vier jaar later dan ook nog maar $45 \%$ bij de UM werkzaam. Dit hoge verloop onder het nieuw aangetrokken personeel verklaart ook het duale karakter van de personeelsopbouw van de UM.

- Van de UD'ers die in 1999 reeds bij de UM werkzaam waren en daar ook in 2004 nog werkten is $20 \%$ in deze jaren doorgestroomd naar een UHD functie, terwijl $3 \%$ van deze UD'ers is doorgestroomd naar een hoogleraarsfunctie

- Er is een aanzienlijke opwaartse mobilteit van OBP'ers. Bijna de helft van de OBP'ers is in de periode 1999-2004 éen of meer schalen hoger ingeschaald. $13 \%$ van de OBP'ers heeft zelfs twee of meer salarisschalen promotie gemaakt. De opwaartse schaalmobiliteit is vooral groot geweest voor degenen die oorspronkelijk in de laagste schalen waren aangesteld. Overigens zijn er tussen faculteiten en ondersteunende diensten aanzienlijke verschillen in de mate waarin het OBP doorstroomt naar hogere salarisschalen.

- $23 \%$ van het wetenschappelijk personeel en $33 \%$ van het OBP zat in 2004 aan het eind van een salarisschaal. In de voorgaande jaren lagen deze percentages vrijwel op hetzelfde niveau.

- Met name de Economische faculteit is een 'stepping-stone' binnen de interne arbeidsmarkt voor OBP'ers van de UM. Vanuit de Geneeskundefaculteit is de 
mobiliteit van OBP'ers naar andere organisaties binnen de UM daarentegen zeer beperkt. Voor de OBP'ers blijken dit dan ook vaker eindplekken te zijn. Het Bureau van de Universiteit trekt ook relatief veel OBP'ers uit de andere organisaties binnen de UM aan. Dit komt waarschijnlijk mede doordat er in het Bureau relatief veel hogere functies voorkomen.

- UD posities worden meestal extern ingevuld, al is er de laatste jaren een toename van de doorstroom van eigen promovendi naar UD functies. UHD functies worden daarentegen veel vaker intern ingevuld. De UHD functie fungeert hierdoor duidelijk als een interne carrièrestap voor het wetenschappelijk personeel. Bij het benoemen van hoogleraren wordt echter weer meer extern geworven, al neemt dit de laatste jaren sterk af.

- De beherend bazen van de capaciteitsgroepen geven gemiddeld hoge (rapport)cijfers voor de kwaliteit van hun medewerkers: vakspecifieke kennis: 8,3; beheersing engels: 7,9 en IT vaardigheden: 7,2. De beherend bazen van de ondersteunende diensten zijn over het algemeen wat kritischer over het competentieniveau van hun dienst: vakspecifieke kennis: 7,6; beheersing engels: 6,4 en IT vaardigheden: 6,7.

\section{HRM beleid}

- Beherend bazen van de ondersteunende diensten hebben een sterkere focus op het leidinggeven dan de beherend bazen van de capaciteitsgroepen. Dit blijkt onder andere uit het feit dat de beherend bazen van de ondersteunende diensten zich meer leidinggevende kwaliteiten toedichten (bijvoorbeeld het consistent uitdragen van de strategie, waardering uiten voor successen en inspanningen, nee kunnen zeggen) en meer gebruik maken van HRM instrumenten dan de beherend bazen van de capaciteitsgroepen.

- In sommige faculteiten worden vacatures voor wetenschappelijk personeel met name vanuit de onderwijsbehoeften ingevuld, terwijl andere faculteiten juist de onderzoekskwaliteiten van sollicitanten belangrijker vinden. Binnen de capaciteitsgroepen bestaat er echter een duidelijke voorkeur voor onderzoek boven onderwijs. Hoewel de beherend bazen aangeven evenveel bezig te zijn met het versterken van de onderzoeksreputatie als met de onderwijsreputatie van hun capaciteitsgroep, krijgen kandidaten met onderzoekskwaliteiten over het algemeen bij een vacature voor een UD de voorkeur boven kandidaten met onderwijskwaliteiten. Ook zien de beherend bazen het liefst dat UD's de meeste tijd aan onderzoek besteden. Opvallend hierbij is dat bijna alle beherend bazen het maximum percentage boven de standaard binnen hun faculteit leggen.

- De beherend bazen vinden functioneringsgesprekken het belangrijkste instrument om hun personeel verder te ontwikkelen. Ook coaching van individuele medewerkers, beoordelingsgesprekken en bij- en nascholing worden belangrijk gevonden. Instrumenten die door de beherend bazen van de capaciteitsgroepen spontaan genoemd worden zijn sabbatical leaves en het stimuleren 
van een tijdelijk verblijf aan een buitenlandse universiteit, terwijl de beherend bazen van de ondersteunende diensten wijzen op het belang van samenwerking met soortgelijke organisaties.

- Prestatiebeloning is geen gemeengoed binnen de UM, en komt nog het meeste voor bij de ondersteunende diensten. Daarbij is er veel vaker sprake van prestatiebeloning op individueel niveau dan van prestatiebeloning op teamniveau. Zo heeft een kwart van de medewerkers in 2004 een gratificatie heeft ontvangen. Wel worden er op 'teamniveau' vaak concrete prestatiedoelen geformuleerd. In de capaciteitsgroepen gaat het dan vooral om onderzoeks- en onderwijsdoelen.

- Gemiddeld genomen heeft 4I\% van de UM-medewerkers in 2004 minimaal één interne of externe cursus of training gevolgd. Het meest wordt aan cursussen op het eigen vakgebied en managementcursussen deelgenomen. Door het personeel in de capaciteitsgroepen worden ook veel trainingen gericht op het geven van onderwijs gevolgd, terwijl cursussen communicatieve vaardigheden en algemene IT vaardigheden bij de ondersteunende diensten populair zijn.

- Ruim $80 \%$ van de beherend bazen van de capaciteitsgroepen en $60 \%$ van de beherend bazen van de ondersteunende diensten geeft aan bij het voeren van het personeelsbeleid bepaalde belemmeringen te ervaren. Meestal gaat het dan om onvoldoende financiële middelen, maar de beherend bazen van de capaciteitsgroepen noemen ook de starheid van het formatiebeginsel en de beperkte doorgroeimogelijkheden voor medewerkers. De beherend bazen in de ondersteunende diensten voelen zich in hun personeelsbeleid belemmerd door het ontbreken van voldoende flexibiliteit (bijvoorbeeld om tijdelijke krachten in te huren of slecht functionerende medewerkers te ontslaan) en de lage mobiliteit van medewerkers. Ten slotte worden zaken genoemd als bureaucratie, de top-down benadering van het bestuur, de starheid van de organisatie en het tegelijkertijd doorvoeren van teveel veranderingen.

\section{Performance indicatoren}

- Het ziekteverzuim op de UM bedroeg in 2004 slechts 3,2\%. Dit is veel lager dan het landelijk gemiddelde van 4,7\% (CBS cijfer voor 2003). Met name op de faculteiten is het ziekteverzuim zeer laag. Mogelijk is er echter sprake van een onderregistratie van het feitelijke verzuim.

- De UM scoort, in vergelijking met het landelijk beeld, goed op het interne rendement van het onderwijs. Bij de meeste faculteiten ligt zowel het propedeuse- als het studierendement hoger dan het landelijk gemiddelde.

- Het externe rendement van het onderwijs verschilt sterk tussen de faculteiten. De arbeidsmarktpositie van afgestudeerden van de faculteit Geneeskunde is het gunstigst: ze hebben de grootste kans op betaald werk, het hoogste bruto uurloon en de beste carrièremogelijkheden. De positie van afgestudeerden van de faculteit Psychologie is het minst gunstig, met name voor wat betreft 
de kans op werk en de loonhoogte. De verschillen in het externe rendement tussen de UM faculteiten weerspiegelen overigens het landelijke beeld.

- De instroom van eerstejaars studenten is sterk gestegen bij de faculteiten Cultuurwetenschappen, Geneeskunde en Psychologie en de UCM. Bij de faculteiten Rechten en Gezondheidswetenschappen is het aantal eerstejaars studenten daarentegen sterk gedaald. Bij de faculteiten Economie en bedrijfskunde en Algemene wetenschappen is er sprake van een lichte daling van de instroom.

- De instroom van buitenlandse studenten is relatief groot bij de faculteiten Cultuurwetenschappen, Economie en bedrijfskunde, Geneeskunde en Psychologie.

- Er is een aanzienlijk verschil in de wetenschappelijke output van de verschillende faculteiten. In 2003 waren er bij de faculteit Geneeskunde 4,5 wetenschappelijke publicaties per mensjaar wetenschappelijk personeel, tegenover slechts I,6 bij de faculteit Economie en bedrijfskunde. Op centraal niveau ontbreekt echter informatie over de kwaliteit van de publicaties, terwijl verschillende faculteiten hieraan steeds meer waarde hechten. Het aantal dissertaties per fte begeleidingscapaciteit (Hoogleraren/UHD's en UD's) liep in 2003 uiteen van 0,36 bij de faculteit Geneeskunde tot 0,13 bij de faculteit Rechten.

- Met name de faculteit Cultuurwetenschappen scoort goed op het aantal vakpublicaties: 3,7 per mensjaar WP. De omzet aan tweede en derde geldstroom per mensjaar is het hoogst aan de faculteit Gezondheidswetenschappen, namelijk 64.500 euro per mensjaar WP. 


\section{Inleiding}

\section{$1.1 \quad$ Inleiding}

De prestaties van een universiteit worden in belangrijke mate bepaald door de kwaliteit van de medewerkers en de mate waarin de universiteit de ontwikkeling van haar medewerkers onderkent. De Universiteit Maastricht (UM) is er zich van bewust dat dit betekent dat er een goed werkklimaat moet zijn waar mensen met plezier werken en hun bijdrage leveren aan de prestaties van de organisatie op het terrein van onderzoek en onderwijs. Een goed Human Resource Management (HRM) kan hier een belangrijke bijdrage aan leveren. De noodzaak tot het voeren van een adequaat HRM beleid wordt momenteel nog versterkt door (I) de krapte op verschillende segmenten van de arbeidsmarkt voor hoger opgeleiden, (2) de voortschrijdende vergrijzing van de medewerkers van de UM en (3) de sterk toegenomen internationale concurrentie op zowel de hogere onderwijsmarkt, als op het terrein van het wetenschappelijk onderzoek.

Een goed HRM beleid stelt zich als doel om voor het personeel optimale omstandigheden te creëren om goed te functioneren, maar ook om aantrekkelijk te zijn als werkgever voor nieuw aan te trekken personeel. In de praktijk wordt het HRM beleid in een organisatie op verschillende niveaus gevoerd. ${ }^{\mathrm{I}}$ Hierbij gaat het enerzijds om het beleid dat bepalend is voor het niveau van de human resources:

- het wervings- en selectie beleid;

- het personeelsontwikkelingsbeleid (HRD);

- het beleid dat van invloed is op het personeelsverloop.

Anderzijds gaat het om het beleid dat bepalend is voor de allocatie van de human resources:

- de onderscheiden functies (job design);

- de personeelsplanning;

- het loopbaanbeleid;

- het competentiemanagement.

Een goed HRM beleid dient daarnaast aandacht te besteden aan wat tegenwoordig vaak wordt aangeduid als de employability van de medewerkers. Centraal daarbij

I. Een verdere uitwerking van dit overzicht is te vinden in J. van Loo en A. de Grip, Loont HRM? Een literatuurverkenning, ROA-R-2002/15, Maastricht, 2002. 
staan de mogelijkheden die medewerkers worden geboden met betrekking tot hun competentie-ontwikkeling en loopbaanperspectieven.

De laatste jaren is er veel onderzoek verricht naar de effecten van de zogenaamde 'High Performance Workplace' op de productiviteit van organisaties. ${ }^{2}$ In deze studies is veel aandacht voor het belang van zelfsturende teams van professionals, die een relatief grote vrijheid van handelen hebben en gefaciliteerd worden door het HRM beleid van de organisatie. Ondanks het feit dat de universiteit hierbij welhaast het 'rolmodel' voor het bedrijfsleven is ${ }^{3}$, hebben ook universiteiten weinig inzicht in de effectiviteit van hun HRM beleid en de effecten daarvan op de employability van het personeel.

\section{HRM Portfolio}

De HRM portfolio zal idealiter op drie verschillende terreinen de relevante ontwikkelingen moeten monitoren en aan elkaar kunnen relateren: ${ }^{4}$

- beschikbare human resources;

- het gevoerde HRM beleid en het gebruik van de aangeboden HRM faciliteiten;

- performance indicatoren

In de eerste plaats gaat het daarbij om indicatoren met betrekking tot de beschikbare human resources, zoals: het werkgelegenheidsaandeel van het wetenschappelijk personeel, het aantal werkenden in de verschillende functies, het aantal dienstjaren, leeftijd en vergrijzing deeltijdwerk, de aard van het dienstverband, het percentage vrouwelijke werknemers en de internationalisering van het personeel. In de tweede plaats gaat het om indicatoren met betrekking tot het gevoerde HRM beleid en het gebruik van de aangeboden HRM faciliteiten, zoals externe versus interne werving, functioneringsgesprekken, persoonlijke ontwikkelingsplannen (POP's), opleidingsbeleid, feedback/ coaching, trainingsparticipatie (vakspecifieke cursussen en trainingen gericht op het vergroten van iemands competenties op het terrein van onderwijs of management), interne promoties, functieroulatie e.d. In de derde plaats zou de HRM portfolio indicatoren moeten bevatten die inzicht geven in bepaalde aspecten van de performance van de organisatie. Hierbij gaat het zowel om vanuit organisatieoogpunt intermediaire prestatiemaatstaven als werknemerstevredenheid, verzuim, personeelsverloop, de loopbaanmogelijkheden en wervingskracht, als om indicatoren die inzicht geven in de prestaties op het terrein van onderwijs en onderzoek. Het spreekt overigens voor zich dat de prestatiemaatstaven die vanuit organisatieoogpunt als 'intermediaire' maat-

2. Een overzicht is bijvoorbeeld te vinden in C. Ichniowski \& K. Shaw, 'Beyond incentive pay: Insiders' estimates of the value of complementary human resource management practices', Journal of Economic Perspectives, I7, I55-I80, 2003.

3. Zie A. de Grip, Van tweedekansonderwijs naar een leven lang leren. De veranderende betekenis van postinitiële scholing, oratie, Universiteit Maastricht, 2000.

4. Zie ook A. de Grip en J. Sanders, Employability Portfolio voor bedrijfssectoren en bedrijven, ROA-R2003/2, Maastricht, 2003 en A. de Grip et al., 'The Industry Employability Index: Taking Acount of Supply and Demand Characteristics', International Labour Review, vol. I43, p. 21I-233, 2004. 
staven kunnen worden gezien, vanuit het oogpunt van de medewerkers tot de 'finale' prestatiemaatstaven van de organisatie kunnen worden gerekend.

De HRM portfolio zal mogelijkheden moeten bieden voor een jaarlijkse benchmarking op verschillende beheersniveaus van de organisatie. Hierbij gaat het in principe om het generen van indicatoren op drie niveaus: het centrale niveau, het facultaire c.q. beheerseenheid niveau en het niveau van de departementen/capaciteitsgroepen. Enkele kernindicatoren uit de HRM portfolio kunnen daarbij ook worden toegevoegd aan de indicatoren met betrekking tot de bedrijfsvoering, ten behoeve van de reguliere planning en control cyclus.

De HRM Portfolio UM beoogt op een viertal aan elkaar gerelateerde punten toegevoegde waarde te bieden ten opzichte van de bestaande dataverzameling binnen de UM:

I. Het biedt een integratiekader voor de opzet van een managementinformatiesysteem op het terrein van HRM, employability en loopbaanontwikkeling.

2. Het maakt de monitoring van HRM en employability in het kader van de jaarlijkse planning en control cyclus mogelijk.

3. Er zijn mogelijkheden voor benchmarking op het gebied van HRM en employability op capaciteitsgroep-/ departementsniveau.

4. Het verkrijgen van inzicht in de effectiviteit van het HRM beleid op centraal niveau en het signaleren van eventuele knelpunten die zich voordoen.

Bij het opstellen van de HRM portfolio UM is zoveel mogelijk gebruik gemaakt van de informatie die reeds beschikbaar is. Op grond van deze informatie is geprobeerd voor de verschillende onderdelen van de HRM portfolio een aantal kernindicatoren te construeren, die een beeld geven van de beschikbare human resources en de ontwikkeling hierin in de afgelopen jaren. Door middel van een enquête onder de leidinggevenden ('beherend bazen') van de capaciteitsgroepen en de ondersteunende diensten is aanvullende informatie verzameld over het in de verschillende organisatieonderdelen gevoerde HRM beleid. Hierbij is ingegaan op de werving en selectie van nieuwe medewerkers, het personeelsontwikkelingsbeleid en de managementstijl van de beherend bazen. Naast deze enquête onder beherend bazen, vereist een optimale invulling van de HRM portfolio ook een enquête onder de UM-medewerkers. Deze enquête is echter dit jaar nog niet uitgezet.

De verder opzet van dit rapport is als volgt. Eerst zal in hoofdstuk 2, op basis van verkennende gesprekken met de directeuren van de verschillende faculteiten en vier ondersteunende diensten, een overzicht worden gegeven van de doelstellingen van de verschillende organisatie-onderdelen en het gevoerde HRM beleid. Daarna wordt in hoofdstuk 3 een overzicht gegeven van de beschikbare databronnen op centraal niveau en op het niveau van de faculteiten en de ondersteunende diensten. In hoofdstuk 4 wordt vervolgens ingegaan op de opzet en inhoud van de enquêtes onder de beherend bazen van de capaciteitsgroepen en ondersteunende diensten. De hoofdstukken 
5 tot en met 8 beschrijven de voor de invulling van de HRM portfolio beschikbare informatie. In deze hoofdstukken worden achtereenvolgens in kaart gebracht: de beschikbare human resources (hoofdstuk 5), de instroom, doorstroom en uitstroom van personeel (hoofdstuk 6), het gevoerde HRM beleid (hoofdstuk 7) en de prestatiemaatstaven met betrekking tot onderwijs en onderzoek (hoofdstuk 8). Ten slotte wordt in Bijlage I een overzicht gegeven van de eerste invulling van de HRM Portfolio voor de UM en de mogelijke verbijzonderingen naar de verschillende faculteiten en ondersteunende diensten. 


\section{Het HRM beleid in faculteiten en ondersteunende diensten}

\section{$2.1 \quad$ Inleiding}

Om een beeld te krijgen van de doelstellingen van de verschillende faculteiten en ondersteunende diensten en het in het verlengde daarvan gevoerde HRM beleid voor wetenschappelijk (WP) en ondersteunend personeel (OBP), zijn er verkennende gesprekken gevoerd met de directeuren en/of decanen van alle faculteiten en vier servicecentra. In dit hoofdstuk zal verslag worden gedaan van deze gesprekken. Daarbij zal achtereenvolgens worden ingegaan op de strategie, de onderwijs- en onderzoeksevaluatie, het wervings- en selectiebeleid, de personeelsontwikkeling en het loopbaanbeleid.

\subsection{Faculteiten}

\section{Faculteit der Geneeskunde (FdG)}

\section{Strategie}

De FdG wil zich zowel binnen als buiten Nederland op onderwijs en onderzoeksgebied meten met andere geneeskundefaculteiten. Zowel bij onderwijs als bij onderzoek is het streven tot de Europese top te behoren. Het onderzoek is in zes instituten ondergebracht en er zijn speerpunten geformuleerd. Er is voor gekozen om deze speerpunten te verdiepen, wat betekent dat onderzoek dat niet binnen de speerpunten past op termijn steeds minder plaats kan krijgen binnen de desbetreffende onderzoekslijn.

In een planning en control cyclus komen eens per jaar de decaan, directeur, wetenschappelijke directeur en de capaciteitsgroepsvoorzitter bij elkaar om de behaalde onderzoeksoutput te bespreken. Hierbij wordt gekeken naar het aantal promovendi, ze en ze geldstroommiddelen en het aantal publicaties. Bij het bepalen of publicaties worden meegewogen in het behaalde resultaat is de aanwezigheid van een impactfactor geldend. Een soortgelijke planning en controle cyclus zal naar alle waarschijnlijkheid ook in het komende jaar voor het onderwijs starten. Hierbij wordt gekeken 
naar welke blokken (per groep) gegeven worden, hoeveel uren hiermee gemoeid zijn en de resultaten en evaluaties. Als laatste stap wordt aan een aanpak van planning en controle richting bedrijfsvoering gedacht. Hierbij zouden cijfers over onder meer ziekteverzuim, personeelsverloop, doorstroom van medewerkers en door de medewerkers gevolgde trainingen aan de orde kunnen komen.

\section{Onderwijs-en Onderzoeksevaluatie}

Bij de Faculteit Geneeskunde zijn de WP medewerkers aangesteld bij de capaciteitsgroepen. Volgens de matrixorganisatie participeren zij in de onderzoekslijnen die ondergebracht zijn bij de onderzoeksinstituten. Het onderwijs wordt geregisseerd door het onderwijsinstituut dat hiervoor formatie beschikbaar stelt aan de capaciteitsgroepen. De capaciteitsgroepen leveren vervolgens de benodigde WP'ers ten behoeve van de invulling van het curriculum. De beherend baas van WP'ers is normaal gesproken de capaciteitsgroepvoorzitter. Deze kan een aantal van zijn managementtaken verder uitbesteden aan werkbazen (HL en UHD), die zo voor het voeren van bijvoorbeeld functioneringsgesprekken verantwoordelijk worden.

Onderwijslast ten opzichte van onderzoekstijd varieert van $40 \%$ onderwijs en $60 \%$ onderzoek tot $50 \%$ onderwijs en $50 \%$ onderzoek. Deze verhoudingen kunnen op capaciteitsgroepniveau ingevuld worden. Bij UHD en HL functies wordt enige tijd voor management taken beschikbaar gesteld.

Het afrekenen op wetenschappelijke publicaties verschilt binnen de capaciteitsgroepen. In sommige groepen zijn vaste afspraken over het aantal te behalen vakpublicaties op bijvoorbeeld jaarbasis gemaakt. Het onderwijs wordt door studentevaluaties beoordeeld. Deze worden door O\&O verzameld en teruggekoppeld aan de docent en/of capaciteitsgroepvoorzitter. In het skills lab wordt door docenten onderwijs gegeven die in vaste dienst zijn aangesteld. Voor het overgrote deel betreft dit artsen. Een aantal van hen is daarnaast nog werkzaam in de praktijk. Zowel onderwijs als ook onderzoek is belangrijk voor een carrière. Wel was onderzoek zeker in het verleden de doorslaggevende factor. Er is op dit moment een werkgroep ingesteld die de mogelijkheid tot het maken van een onderwijscarrière (na promotie) onderzoekt. Het betreft hier dan tevens een onderzoek naar de mogelijkheid om met een (zware) onderwijstaakstelling te kunnen doorstromen naar de functie van UHD.

\section{Werving en selectie}

Een van de HRM problemen voor geneeskunde heeft betrekking op medewerkers die op (tijdelijke) ze geldstroomprojecten werken. Deze medewerkers kunnen in principe slechts voor de periode van een bepaald project bekostigd worden, terwijl na verloop van tijd wel een vaste aanstelling aangeboden moet worden. Hier moet per functie bekeken worden hoeveel mensen er daadwerkelijk een vaste aanstelling kunnen krijgen. Dit is afhankelijk van de gemiddelde verwachte ze geldstromen. 
Vacatures zijn over het algemeen makkelijk in te vullen. Carrières van OBP'ers worden in eerste instantie binnen de faculteit gemaakt.

\section{Personeelsontwikkeling en loopbaanbeleid}

Men is begonnen om het houden van functioneringsgesprekken structureel te inventariseren, maar hierover zijn nog geen cijfers beschikbaar. Trainingen kunnen worden bekostigd uit opleidingsbudgetten op decentraal (capaciteitsgroep)niveau. Daarnaast worden er trainingen gevolgd die op centraal niveau door het loopbaancentrum en door het ICTS worden aangeboden in het kader van het HRM programma. Over de deelname aan de op decentraal niveau bekostigde trainingen wordt niet structureel informatie verzameld.

Er wordt bij het WP ook uitgegaan van een carrièrebeginsel. Uitgangspunt is dat het belangrijk is om talent te behouden: universitaire docenten, die voldoen aan de eisen voor universitair hoofddocent komen in principe in aanmerking voor deze hogere positie. Bij een dergelijke promotie op persoonlijke titel wordt wel gekeken naar de consequenties die de promotie voor de capaciteitsgroep heeft.

In de onderzoeksinstituten is de directeur verantwoordelijk voor het OBP dat voor de instituten werkt. Hij of zij voert POP- en functioneringsgesprekken. Voor het OBP wordt gekeken welke trainingen noodzakelijk zijn. Dit kan een training zijn die verplicht is voor bepaalde functies, ter ontwikkeling van een medewerker of om een functie beter te kunnen vervullen.

\section{Faculteit der Gezondheidswetenschappen (FdGW)}

\section{Strategie}

Het onderzoeksthema van de Faculteit der Gezondheidswetenschappen is de bevordering van gezondheid in algemene zin. Hierbij kan worden gedacht aan public health en geestelijke gezondheidszorg. Het onderzoek is gemeenschappelijk met de Faculteit der Geneeskunde ondergebracht in de onderzoeksscholen CAPRI, NUTRIM, en EPP. Wetenschappelijk personeel is lid van een capaciteitsgroep en voor de onderzoekstijd verbonden aan minimaal één van de onderzoeksinstituten.

\section{Onderwijs-en Onderzoeksevaluatie}

De druk vanuit het onderwijs is hoog, zodat (tijdelijk) een hogere onderwijsformatie met toegevoegde docenten soelaas moet bieden. Capaciteitsgroepvoorzitters kunnen de verdeling van onderwijs ten opzichte van onderzoeksuren per medewerker variëren indien men gemiddeld op de vastgelegde verdeling uitkomt. Formatieplaatsen hebben een aandeel van $50 \%$ onderzoekstijd en $50 \%$ voor onderwijstaken (met een variatie van $60-40$ of $40-60)$. 
Onderzoeksoutput wordt bij gezondheidswetenschappen aan de hand van de "van Raan" Methode bekeken. Hiervoor wordt een wereldgemiddelde voor citaties uit publicaties berekend. De onderzoeksinstituten kunnen dan zien hoe hun wetenschappelijke impact ten opzichte van de rest van de wereld is. Als geheel is de faculteit niet direct vergelijkbaar met andere faculteiten in de wereld; hiervoor is het bestreken vakgebied te breed. Er is derhalve ook niet gekozen voor een faculteitsbrede onderzoeksbenchmark.

\section{Werving en selectie}

Vacatures worden normaal gesproken door capaciteitsgroepen ingevuld. Zij bepalen in overleg met de onderzoeksdirecteuren het profiel van een vacature. Bij functies die bekostigd worden uit de Ie geldstromen staat de invulling vanuit het onderwijs centraal. Hiervoor worden over het algemeen medewerkers met specifieke onderzoeks- en onderwijsprofielen gezocht. Er wordt bij invulling van de vacature dan ook gekeken naar onderwijs- en onderzoeksprestaties. Medewerkers op projecten vanuit de 2 e en 3 e geldstroom worden vooral op hun onderzoeksprofiel uitgezocht.

Vacatures zijn - afhankelijk van de functie - gemakkelijk of moeilijk in te vullen. Zo was de invulling van AiO plekken in de afgelopen jaren moeilijk. Dit is in de laatste jaren echter volledig veranderd. Ook bij OBP functies is er volop keuze voor nieuw personeel. Functies voor universitaire docenten zijn soms moeilijker in te vullen, omdat hier doorgaans naar een heel specifieke invulling van een bepaalde vacature gezocht wordt. UHD posities worden over het algemeen intern door promotie van UD's ingevuld. Voor hoogleraarposities is het soms moeilijk om een geschikte kandidaat te vinden. Hiervoor geldt hetzelfde als voor UD's: specifieke eisen aan de functie en de vakinhoudelijke kennis maken de pool van mogelijke kandidaten klein. Het vrouwenbeleid zorgt er soms voor dat procedures om vacatures in te vullen langer lopen. Flexibele werktijden worden in beperkte mate aangeboden. Er wordt een terughoudend beleid met betrekking tot het keuzemodel-arbeidsvoorwaarden en meer in het bijzonder de tijd-voor-geld arrangementen gevoerd.

\section{Personeelsontwikkeling en loopbaanbeleid}

Carrières van het WP worden bepaald door een combinatie van onderzoeks- en onderwijsprestaties. Afhankelijk van de capaciteitsgroep zijn kwalitatieve en kwantitatieve doelen voor het publiceren vastgesteld. Hierbij wordt gekeken naar de kwaliteit van een publicatie in termen van het prestige van de tijdschriften waarin men publiceert. Vooral wordt gekeken naar de impactscore van het tijdschrift.

Onderwijsprestaties worden ook meegenomen. Hier is het belangrijk dat het gegeven onderwijs goed geëvalueerd wordt. Ook de zwaarte (Bachelor of Master, coördinator of tutor) van het gegeven onderwijs is voor het bereiken van sommige posities (UHD/ HL) van belang. Door jonge medewerkers meer en meer verantwoordelijkheid te 
geven in onderwijs en het ontwikkelen van vakken, worden zij in staat gesteld hun onderwijscompetenties op te bouwen. Binnen de faculteit wordt ook een discussie gevoerd of onderwijscarrières binnen de faculteit gewenst zijn. Dat wil zeggen dat zeer goed functionerende docenten ook de wetenschappelijke carrièreladder kunnen doorlopen zonder aan de strikte eisen voor wetenschappelijke output te voldoen.

Functioneringsgesprekken worden regelmatig gehouden. Er is gekozen om jaarlijks een functioneringsgesprek aan te bieden en om de drie jaar een beoordelingsgesprek. Dit wordt voor meer dan $80 \%$ van alle gesprekken gehaald. Er wordt strikt op gelet dat functioneringsgesprekken voor Aio's (eerstejaarsgesprekken) zeker gehouden worden. Binnen de capaciteitsgroep BEOZ worden ook persoonlijke ontwikkelingsplannen (POPs) gemaakt. Dit wordt gezien als een pilot voor een eventuele structurele invoering van POPs onder het wetenschappelijk personeel.

Functies voor het OBP volgen de UFO profielen. Er zijn nog geen duidelijke resultaatafspraken, wel worden de taakgebieden beoordeeld. Voor het OBP is binnen de faculteit een bedrag van EUR 400 per persoon per jaar beschikbaar voor trainingen.

Buiten de door de universiteit aangeboden trainingen, zijn er geen facultaire middelen beschikbaar voor trainingen van wetenschappelijke medewerkers. Wel zijn er coaching en trainingstrajecten voor leidinggevenden. Voor wetenschappelijk personeel wordt de vakgerelateerde ontwikkeling als veel belangrijker gezien. Deze ontwikkeling vindt niet plaats via formele trainingen maar door congresbezoek e.d. Hiervoor worden capaciteitsgroepsmiddelen gebruikt.

Wel wordt jong wetenschappelijk talent ondersteund. Zo zijn drie studenten en twee $\mathrm{AiOs}$ in staat gesteld om binnen tien maanden een onderzoeksvoorstel voor externe financiering te ontwikkelen. Dit wordt uit Ie geldstroommiddelen gefinancierd.

Uit het tevredenheidsonderzoek van het IVA zijn afspraken per capaciteitsgroep naar voren gekomen. De al bestaande professionalisering van leiderschap kwam zo in een stroomversnelling. Hiervoor wordt aan leidinggevenden coaching en trainingen aangeboden.

Binnen de faculteit wordt wel gekeken naar een mogelijk carrièrebeleid voor het OBP, maar er is weinig personeelsmobiliteit. Wel is er een beperkte mobiliteit tussen vergelijkbare functies van geneeskunde, het AZM en gezondheidswetenschappen. Binnen functies wordt wel eens gekeken of er functieverbreding kan plaatsvinden.

Men streeft ernaar om binnen de vaste formatie van het OBP IO\% flexibel te houden. Een van de belemmeringen bij deze flexibiliteit is echter dat er weinig verloop onder het ondersteunend personeel is. Zowel voor het OBP als voor het WP wordt het formatiebeginsel toegepast. 


\section{Faculteit der Rechtsgeleerdheid (FdR)}

\section{Strategie}

In het afgelopen jaar heeft er in de $\mathrm{FdR}$ een reorganisatie plaatsgevonden onder het WP en OBP. Alle OBP'ers moesten, aan de hand van UFO en de bijbehorende competenties, opnieuw solliciteren naar functies. In totaal werd overigens slechts 3 FTE afgebouwd. Onder het WP betekende de reorganisatie dat alleen onderzoek behouden blijft dat in één van de twee onderzoeksscholen, Ius commune of Rechten van de mens, verricht wordt.

\section{Onderwijs- en Onderzoeksevaluatie}

Er bestaat een formatieplan per capaciteitsgroep. Deze geeft de samenstelling van het WP weer. Alle wetenschappelijke medewerkers zijn lid van een van de twee onderzoeksscholen. Dit is ook het resultaat van de specialisering van het onderzoek op de twee bovengenoemde trajecten.

Het WP dient ten minste drie wetenschappelijke publicaties (3x 30 punten, totaal 90 punten) binnen één jaar te hebben. Maar voor het maken van een handboek (270 punten) kan het soms noodzakelijk zijn om over een iets langere termijn te kijken (3 jaren). Dit wordt daarom meegenomen in de functionerings- en beoordelingsgesprekken. Uiteindelijk wordt een medewerker om de drie jaar afgerekend op zijn publicaties. Deze kunnen echter ook tussentijds bij de jaarlijkse functioneringsgesprekken geëvalueerd worden. De beoordeling van publicaties vindt in eerste instantie plaats door de werkbaas. In geval van geschillen zal de voorzitter van de wetenschapscommissie een oordeel vellen. De doelstelling van drie vakpublicaties per jaar is een richtlijn die als minimum geldt. Van UHD's en hoogleraren wordt wel verwacht dat zij zich met meer publicaties of op andere manier wetenschappelijk profileren. Rechten gebruikt voor het bijhouden van de onderzoeksprestaties het METIS systeem.

WP'ers houden zelf onderwijsdossiers bij, waarin de door hen gegeven blokken, gemakkte toetsvragen, de beoordeling door een referent, blokboeken en het oordeel van de studentenevaluaties verzameld worden. De evaluaties worden verzameld door de sectie onderwijsontwikkeling.

De verschillende studierichtingen van de faculteit worden nationaal en internationaal geëvalueerd. Deze evaluaties worden ook gebruikt om zich met andere rechtenfaculteiten te vergelijken. Er bestaat derhalve geen behoefte om nog additionele benchmarks in te voeren. 


\section{Werving en selectie}

Carrières en vacatures worden op basis van een voorstel van de capaciteitsgroep ingevuld. De faculteit vindt talent scouting bij jonge onderzoekers belangrijk. Tot nu toe wordt dit gedaan door getalenteerde promovendi vanuit de studentenpopulatie aan te trekken, maar in toekomst moet dit ook gebruikt worden om jonge, gepromoveerde onderzoekers van elders aan te trekken. Vacatures worden over het algemeen gemakkelijk ingevuld.

\section{Personeelsontwikkeling en loopbaanbeleid}

Elke functie is in wezen een eindfunctie. Maar als iemand na 5 jaar nog in dezelfde functie werkzaam is, wordt er wel een carrièregesprek gevoerd, om te kijken of zowel de medewerker als de faculteit met de invulling van de positie tevreden is. Over het algemeen is het verloop van personeel redelijk laag, maar dit was vroeger duidelijk hoger.

Alle medewerkers krijgen eens per jaar een functioneringsgesprek. Bij het WP wordt dit na drie jaar vervangen door een beoordelingsgesprek waarin de prestaties op onderzoek en onderwijs worden beoordeeld. Voor het OBP wordt jaarlijks een functioneringsgesprek, POP en beoordelingsgesprek gehouden. Hierin worden het functioneren, de mogelijke ontwikkeling en de carrièreperspectieven van een medewerker besproken. Vooral voor het OBP kan bij trainingen teruggekoppeld worden naar de 360 graden evaluatie en de in het POP genoemde ontwikkelpunten.

Trainingen kunnen via $\mathrm{P} \& \mathrm{O}$ aangevraagd worden en hiervan wordt ook volop gebruik gemaakt. De faculteit wil met name de IT vaardigheden van docenten (WP) uitbreiden, zodat deze goed op de nieuwe onderwijsvormen (blackboard) voorbereid zijn . Ook wordt van alle medewerkers verwacht dat zij tweetalig zijn (Nederlands en Engels). Voorzover nodig zullen hiervoor trainingen aangeboden worden. Ook bestaan er onderwijstrainingen. Alle andere trainingen moeten worden aangevraagd. Vervolgens wordt getoetst of deze trainingen noodzakelijk of wenselijk zijn voor de in te vullen functie.

Het OBP ziet voornamelijk de eigen faculteit als werk- en carrièreplek. Voor hogere functies wordt echter ook buiten de faculteit gekeken en in sommige gevallen ook buiten de universiteit. Aanstellingsgesprekken met OBP'ers worden door de directeur en de werkbaas gevoerd. 


\section{Faculteit der Economische Wetenschappen en Bedrijfskunde (FdEWB)}

\section{Strategie}

Doel van de faculteit is om haar kwaliteit door accreditaties en het behalen van hoge scores in vergelijkend onderzoek op Nederlands en Europees niveau te bewijzen. Daarbij is het doel om niet alleen op onderwijs- maar ook op onderzoeksgebied duidelijk aan de bovenkant van de Europese economische faculteiten mee te draaien. Voor onderzoeksinstituten die vooral door $2 \mathrm{e}$ en $3 \mathrm{e}$ geldstromen functioneren, ROA en MERIT, is de doelstelling dat zij voor de faculteit interessant (contract-)onderzoek verrichten.

De onderzoeksstrategie, breed of diep, verschilt per departement. Zo is de opzet binnen Algemene Economie redelijk breed te noemen, terwijl bij Marketing voor een duidelijk meer specifieke strategie gekozen wordt. In de nabije toekomst zal bij de afrekening op onderzoek vooral op publicaties in de hoger geclassificeerde tijdschriften worden gelet; op departementsniveau zijn hieraan ook financiële prikkels verbonden. Onderzoekspresentatie en -publicatie buiten de wetenschappelijke tijdschriften is echter zeer gewenst. Zo kunnen krantenartikelen en deelname aan publieke discussies door wetenschappers een uithangbord zijn voor de faculteit. Hieraan zijn op departementsniveau nog geen financiële prikkels verbonden.

De faculteit streeft ernaar om op onderwijsgebied een hoog studierendement te halen. Ook een spreiding van de herkomst van studenten van binnen en buiten de EU wordt als doel gezien. Dit vooral om de internationale studierichtingen ook een duidelijk internationaal karakter te geven. De faculteit maakt gebruik van de studentenpanels (Flycatcher) en de onderwijsevaluaties die ook structureel worden verzameld. Een ander punt waarop vanuit de faculteit gelet wordt, is het arbeidsmarktrendement van de afgestudeerden. Hiervoor wordt de monitor onder afgestudeerden van het ROA gebruikt.

\section{Onderwijs- en Onderzoeksevaluatie}

Wetenschappelijk personeel wordt geacht voor de helft van de tijd met onderwijs bezig te zijn. 40\% van de tijd is te besteden aan onderzoek en IO\% aan administratieve taken. Deze afspraken zijn met de departementen gemaakt via de bekostigingsregels van onderzoek en onderwijs. Departementen hebben wel de vrijheid om op individueel niveau van deze regel af te wijken. Zo gebeurt het redelijk vaak dat binnen een departement leden van de onderzoeksschool meer tijd voor onderzoek krijgen en minder onderwijsuren.

Op personeelsgebied wordt met functie- en beoordelingsgesprekken gewerkt. Onderwijs is slechts in beperkte mate belangrijk voor iemands carrière. Vooral de wetenschappelijke ontwikkeling is belangrijk, al moet het onderwijs wel als voldoende 
gewaardeerd worden. Dit is enigszins anders voor de graduate school GSIM. Hier vraagt het onderwijs bijzondere vaardigheden van potentiële docenten, ook al blijft een degelijke onderzoekservaring belangrijk.

\section{Werving en selectie}

Vacatures op UD en AiO niveau zijn makkelijk te vervullen. Op UHD en HL niveau is dit vaak moeilijker. Belemmerende factoren kunnen, naast het salaris en bijkomende faciliteiten, ook het ontbreken van "matchende" aanbiedingen zijn voor de partner van een beoogde hoogleraar of UHD. Zeker gezien de ligging van Maastricht buiten de Randstad wordt vanuit het partnerperspectief door kandidaten nog al eens afgehaakt. Een "partnerbeleid” voor de gehele universiteit zou wellicht ook voor andere faculteiten soelaas bieden.

\section{Personeelsontwikkeling en loopbaanbeleid}

Voor het WP wordt een combinatie van het formatie- en carrièrebeginsel gehanteerd. In beginsel moet voor een bevordering een formatieplaats beschikbaar zijn. Als een departement middelen heeft, kan promotie ook op persoonlijke titel plaatsvinden. Dit is zeker van belang om wetenschappers, die elders aanbiedingen krijgen, te behouden. Bij de samenstelling van het wetenschappelijk personeel wordt ernaar gestreefd om een kwart van de UHD/HL posities door vrouwelijke wetenschappers te bezetten. Vacatures kunnen vaak niet zoals gewenst door vrouwelijke kandidaten ingevuld worden omdat deze vaak minder geografische mobiliteit vertonen.

Bij carrièrebeslissingen zijn beoordelingsgesprekken belangrijk. Voor hogere posities worden beoordelingen gegeven vanuit een commissie. In het geval van UHD posities bestaat deze commissie uit leden van binnen en buiten het betreffende departement. In het geval van hoogleraren bestaat de commissie uit de decaan en oud-decanen. Er wordt gestreefd om op korte termijn duidelijke criteria voor UHD benoemingen te hanteren voor de gehele faculteit.

Ondersteunend en beheerspersoneel (OBP) wordt tot nu toe op ad-hoc basis geëvalueerd. Productiviteitsmaatstaven zijn nog niet volledig geïmplementeerd. Het INK biedt aanknopingspunten om de geleverde prestaties beter terug te kunnen koppelen. Er worden wel zo veel mogelijk concrete afspraken met de afdelingshoofden gemaakt en tussen afdelingshoofden en hun personeel. Hierdoor is een indirecte afrekening op output al mogelijk. Er wordt hierbij gebruik gemaakt van de terugkoppeling vanuit het studentenpanel, visitatiecommissies en benchmarks voor zover zij betrekking hebben op het OBP.

Vanuit de faculteit worden de intra-universitaire carrières van OBP medewerkers ondersteund. Ook bestaan er binnen de faculteit voldoende mogelijkheden voor het OBP. Talentvolle OBP'ers worden ondersteund en daardoor voorbereid op een 
carrière binnen de faculteit. Tevens komen bij functioneringsgesprekken regelmatig persoonlijke ontwikkelingsplannen (POP) aan bod.

Training voor wetenschappelijk personeel vindt incidenteel plaats, wanneer medewerkers zelf aangeven dat er behoefte aan bestaat. Wel worden trainingen en individuele coaching aangeboden aan leidinggevenden. Het opleidingsbudget van de faculteit blijkt tot nu toe toereikend te zijn voor het bekostigen van de trainingen.

Het belang van het onderzoek naar de werknemerstevredenheid (IVA-enquête) leeft nog niet. Er wordt ook nog niet structureel naar cijfers over het verloop gekeken.

\section{Faculteit der Cultuurwetenschappen (FdCW)}

\section{Strategie}

$\mathrm{Na}$ een fase van verandering en consolidatie in het afgelopen jaar is de faculteit druk bezig om de nieuwe, Engelstalige studierichtingen (Bachelor European Studies, masters EPA en ESST) vorm te geven. Het aantal studenten is gegroeid van 400 in 2000 tot 1.200 in 2005 . Verder stond het onderwijs vanaf september 2005 in het teken van de zes nieuwe masteropleidingen. De faculteit heeft wel aandacht voor de beroepsuitoefening na de studie. De studie is echter geen beroepsopleiding. Daarom is de faculteit niet structureel bezig met de vraag waar hun studenten werk vinden en hoe hun opleiding aansluit op de arbeidsmarkt. De studie CW en ES is ook niet bedoeld om directe vaardigheden voor de arbeidsmarkt te vergaren. De ervaring leert dat de afgestudeerden (van de oude studierichting CW) goed bij (semi-) overheden terecht komen, vaak in functies op een cultureel terrein. Verder zijn er weinig studies en faculteiten waarmee de FdCW haar functioneren kan vergelijken. Alleen de Universiteit van Osnabrück heeft een enigszins met European Studies vergelijkbare studie. Het onderzoek van de faculteit is interdisciplinair gericht en in drie afdelingen, maar ook in zeven themata geordend. Het onderzoek wordt versterkt via de breedtestrategie.

\section{Onderwijs- en Onderzoeksevaluatie}

De functioneringsgesprekken met de hoogleraren worden door de decaan gevoerd, de overige door de voorzitters van de capaciteitsgroepen respectievelijk het hoofd van het bureau. De onderwijsevaluatie is de taak van de onderwijsdirecteur, respectievelijk van de opleidingsdirecteuren. De evaluatie van de tutoren is bekend bij de opleidingsdirecteuren en wordt doorgegeven aan de voorzitters van de capaciteitsgroepen. Op dit terrein worden echter nog weinig data structureel verwerkt of gebruikt. De onderwijsevaluatie wordt wel teruggekoppeld naar de tutoren en de blokcoördinator en wordt in principe ook meegewogen in de functioneringsgesprekken. Onderwijsevaluaties zijn beschikbaar per tutor en worden bewaard door Bureau Onderwijs. 
Ook evaluaties van de facultaire studentenvereniging worden gebruikt bij het beoordelen van blokken en zo indirect bij het beoordelen van medewerkers.

De verantwoordelijkheid voor de evaluatie van het onderzoek ligt bij de onderzoeksdirecteur. Per medewerker worden de onderzoeksresultaten verzameld, waarbij er wel een onderscheid wordt gemakt tussen tijdschriften, boeken, boekbijdragen enz., maar niet in de zin van "puntentelling". Artikelen in "peer-reviewde" tijdschriften worden wel belangrijk geacht. De disciplines van cultuurwetenschappen verschillen echter te veel van de andere disciplines in hun manier van "wetenschappelijk publiceren" om een dergelijk onderscheid te rechtvaardigen.

\section{Werving en selectie}

In de Faculteit der Cultuurwetenschappen is het personeel georganiseerd volgens een matrixstructuur. Basis is de disciplinaire capaciteitsgroep. Het wetenschappelijk personeel neemt van daaruit deel aan een van de drie onderzoeksafdelingen en geeft onderwijs in een van de studierichtingen. Bij de aanstelling van nieuwe (universitaire) docenten is op dit moment, gezien het begin van de European Studies, de behoefte vanuit het onderwijs doorslaggevend. Het onderzoek van de nieuwe medewerker wordt dan bij een passende onderzoeksgroep geplaatst. Dit is vanzelfsprekend anders voor ze geldstroom projecten, waar de inhoud van het project het onderzoeksprofiel van een medewerker bepaalt. Doelstelling van de faculteit is om onderwijs en onderzoek op UD/UHD/HL gecombineerd te houden. Toegevoegde docenten worden ingeschakeld, maar voor ongeveer IO $\%$. $\mathrm{Zij}$ worden voor 2 tot 3 jaar in dienst genomen (voor $0,8 \mathrm{fte}$ ) en geven alleen maar onderwijs. Het wetenschappelijk personeel dient zijn tijd voor $55 \%$ aan onderwijs te besteden, $40 \%$ van de tijd is voor onderzoek gereserveerd en $5 \%$ voor administratieve functies. Verantwoordelijk voor het onderwijs zijn de opleidingsdirecteuren, die in overleg met de capgroepvoorzitters de inzet van het wetenschappelijk personeel in de verschillende blokken bepalen. Bij capaciteitsproblemen van de opleidingsdirecteuren en de capgroepvoorzitters wenden zij zich tot de decaan die dan eventueel vacatures openstelt.

Nieuwe medewerkers worden voorgedragen door een ad hoc adviescommissie (benoemd door de decaan). Een voordracht wordt ter advisering voorgelegd aan de onderwijs- en onderzoeksdirecteur en vervolgens benoemt de decaan. Tot nu toe blijkt het redelijk gemakkelijk om bestaande vacatures in te vullen (voornamelijk op UD niveau), omdat de faculteit in het kader van de internationalisering tracht meer buitenlandse medewerkers aan te trekken. Een grote belemmering voor het werven van buitenlandse (vooral niet-EU) medewerkers is de bureaucratie rond het verkrijgen van een werkvergunning voor deze medewerkers. AiO plekken zijn soms moeilijker in te vullen. Men wil hier een combinatie hebben van AiO's uit "eigen huis" - dus voormalige studenten - en van buitenaf. 


\section{Personeelsontwikkeling en loopbaanbeleid}

Promotie van een UD naar een UHD functie gaat normaal gesproken volgens het formatiebeginsel: er moet een functie vacant zijn. In uitzonderingsgevallen kan een promotie ook op persoonlijke titel plaatsvinden. Interne kandidaten voor een promotie worden intern beoordeeld op hun onderwijs en extern op hun onderzoek door drie deskundigen uit hetzelfde vakgebied. Verder moet een kandidaat voldoende managementkwaliteiten voor deze functie hebben. Overgangen van een lagere UD2 naar een hogere UDi functie worden door "goed" functioneren bepaald. Hetzelfde geldt voor de overgang van $\mathrm{UHD}_{2}$ naar UHDI.

AiO's die niet binnen vier jaar hun promotie afronden, kunnen een verlenging krijgen als daarvoor gegronde redenen aanwezig zijn, anders bijvoorbeeld een toegevoegd docent (TD) positie gebruiken om in hun (eigen) tijd de promotie af te ronden. Deze AiO's kunnen pas na afronding van de promotie aangesteld worden als UD.

De faculteit hecht grote waarde aan het integreren van buitenlandse docenten en verplicht deze dan ook om Nederlands te leren. Hiervoor worden cursussen gegeven door het talencentrum. Ook een tutortraining behoort tot de vaste training van nieuwe medewerkers. Verder moet het WP zelf de trainingen aandragen die zij willen volgen. Men wil vaardigheden niet afdwingen. Alleen leidinggevenden wordt in het kader van het UM/HRM project aangeraden om de aangeboden "Krauthammer" trainingen of een ander training te volgen.

Het OBP heeft een heel andere dynamiek. Hier wordt de hele universiteit als "interne arbeidsmarkt" beschouwd waarbinnen carrière kan worden gemaakt. Functieroulatie - voor zover gewenst vanuit de medewerker - vindt universiteitsbreed plaats. Voor OBP'ers wordt het belangrijk geacht om duidelijke functioneringsgesprekken met bijbehorende POP's te maken. Bij het OBP is het volgen en inpassen van trainingen in hun POP veel belangrijker dan bij het WP. De directeur bedrijfsvoering is hiervoor verantwoordelijk en koppelt dit terug naar de decaan.

\section{Faculteit der Psychologie (FdP)}

\section{Strategie}

De faculteit bestaat nu ruim tien jaar en richt zich vooral op cognitieve en biologische psychologie. De beginfase kenmerkte zich door het opzetten van het onderwijs. Het onderzoek werd in eerste instantie "erbij gedaan", omdat in de opbouwfase de volledige aandacht gericht moest worden op het ontwikkelen en uitvoeren van vakken en curricula.

De personeelsformatie stond dus volledig in het kader van het onderwijs, waarbij ook veel gebruik werd gemaakt van toegevoegde docenten. Inmiddels is de opbouwfase 
afgesloten en is de studenteninstroom gestabiliseerd. Pas in 1999 kon meer aandacht worden besteed aan onderzoeksprestaties.

Het verkrijgen van 2 e geldstroommiddelen wordt gestimuleerd. Standaard wordt het binnenhalen van grotere onderzoeksbeurzen gematched met onder meer het financieren van een $\mathrm{AiO}$ plek voor een onderzoeksproject. Voor een onderzoeker kan het binnenhalen van geld behalve vrijstelling van (sommige) onderwijsverplichtingen ook een opstapje in de carrière betekenen. Maar het is niet zo dat de faculteit aan alle wensen van succesvolle onderzoekers tegemoet wil en kan komen. ze geldstroommiddelen spelen in mindere mate een rol. Er zijn slechts enkele opdrachten vanuit de industrie voor een deelgebied van het onderzoeksterrein.

Voor het creëren van $\mathrm{AiO}$ posities is men ten dele afhankelijk van het binnenhalen van 2 e geldstroommiddelen. Er wordt wel getracht om talentvolle jonge studenten en onderzoekers een "startfinanciering" te geven waarmee zij een onderzoeksvoorstel kunnen uitwerken. Zo maken zij kans op financiering van hun promotieonderzoek.

\section{Onderwijs- en Onderzoeksevaluatie}

De verdeling van werktijd voor onderwijs, onderzoek en administratieve taken varieert van $55 \%$ onderwijs en $45 \%$ onderzoek voor TD, $50 \%$ onderwijs en $50 \%$ onderzoek voor UD, naar $45 \%$ onderwijs, $45 \%$ onderzoek en IO $\%$ administratieve taken voor UHD en $40 \%$, 40\% en $20 \%$ voor HL. Deze verdeling wordt gestuurd door het geven van middelen en vorderingen van onderwijsuren aan capaciteitsgroepen. De interne verdeling kan daardoor licht variëren. Verschuivingen binnen de capaciteitsgroepen zijn mogelijk en vinden ook geregeld plaats, bijvoorbeeld als wetenschappelijk personeel door het verkrijgen van middelen uit bijvoorbeeld de 2 e geldstoom meer tijd voor onderzoek kan uittrekken. Zo is door het behalen van enkele grotere beurzen een aantal onderzoekers voor een groot deel vrijgesteld van hun onderwijs.

Binnen de capaciteitsgroepen vinden ook afspraken plaats over het verwachte outputniveau van het onderzoek. Bij één van de capaciteitsgroepen worden zelfs expliciete afspraken gemaakt ten opzichte van het minimum aantal publicaties en hun kwaliteit. Hierop worden medewerkers afgerekend. Dit wordt onder meer gebruikt bij vraagstukken over bevordering en voor beslissingen over verlenging dan wel omzetting van een tijdelijk contract in een vast contract. Onderwijsprestaties van docenten komen ook in functioneringsgesprekken ter sprake en zijn mede bepalend voor het bereiken van een volgende carrièrestap.

De faculteit vindt het behalen van goede resultaten op onderwijsgebied van groot belang. Dit komt onder meer tot uitdrukking in het formatiebeginsel dat gericht is op de te geven vakken en de onderwijsspecialismen. De formatie is primair gericht op het te geven onderwijs. Opleidingsdirecteuren bepalen in samenwerking met het bureau onderwijs en de onderwijscommissie de te geven vakken. Deze worden gevuld 
met medewerkers van de capaciteitsgroepen die zo de norm-uren per capaciteitsgroep invullen.

Onderzoekers zochten in beginsel aansluiting bij onderzoeksscholen buiten de faculteit. Inmiddels is een "virtueel" onderzoeksinstituut opgericht, dat het onderzoek van de faculteit in alle onderzoeksscholen moet bundelen.

Bij het ondersteunende personeel kan onderscheid worden gemaakt tussen secretariële ondersteuning, medewerkers financiën, personele zaken, bureau onderwijs - waarin ook PR en voorlichting en internationalisering zijn ondergebracht - ICT en onderzoeksondersteuning. Het niveau van de onderzoeksondersteuning wordt naar afspraak met de onderzoeksraad vastgesteld. ICT en secretariële ondersteuning hebben geen vaste afspraken maar worden op "klachtenbasis" gecontroleerd. Als weinig klachten binnenkomen, kan aangenomen worden dat het serviceniveau voldoende is.

\section{Werving en selectie}

De organisatie is in een "steady-state". Hierdoor kan in mindere mate gebruik worden gemaakt van tijdelijke contractanten op TD en UD niveau. Dit maakt het makkelijker om mensen aan te trekken en aan zich te binden.

\section{Tabel 2.1}

Allocatie en trainingen WP

\begin{tabular}{|c|c|c|c|}
\hline & $\begin{array}{l}\text { Tijdsverdeling WP: } \\
\text { Onderwijs/ } \\
\text { Onderzoek/ } \\
\text { Administratieve } \\
\text { taken } \\
\%\end{array}$ & $\begin{array}{l}\text { Opvullen vacature vanuit } \\
\text { behoefte m.b.t. }\end{array}$ & Trainingsbeleid \\
\hline $\mathrm{FdG}$ & $40 / 60-50 / 50$ & Onderzoek & $\begin{array}{l}\text { Trainingsbudgetten op decentraal niveau. } \\
\text { Managementtrainingen voor UHD / HL. }\end{array}$ \\
\hline FdGW & $50 / 50$ & Onderwijs & $\begin{array}{l}\text { Trainingsbudgetten op facultair niveau slechts voor OBP. WP heeft } \\
\text { vooral baat bij vakspecifieke trainingen die uit capgroepmiddelen } \\
\text { betaald worden. Trainingstrajecten voor leidinggevenden. }\end{array}$ \\
\hline $\mathrm{FdR}$ & $50 / 50$ & Onderwijs en onderzoek & $\begin{array}{l}\text { Aanvraag centraal via P\&0. Met name behoefte aan } \\
\text { onderwijsgerelateerde IT trainingen voor WP. }\end{array}$ \\
\hline FdEWB & $50 / 40 / 10$ & Verschillend per capgroep & $\begin{array}{l}\text { Trainingen voor WP incidenteel. Wel structureel voor } \\
\text { leidinggevenden en OBP. }\end{array}$ \\
\hline $\mathrm{FdCW}$ & $55 / 40 / 5$ & Onderwijs & $\begin{array}{l}\text { Initiatief van medewerker. Vanuit de faculteit wordt slechts tutor } \\
\text { en talentraining actief aangeboden aan WP. OBP wordt training } \\
\text { binnen POP besproken. }\end{array}$ \\
\hline $\mathrm{FdP}$ & $\begin{array}{l}50 / 50 \text { (UD) } \\
40 / 40 / 20 \text { (HL) }\end{array}$ & Onderwijs & $\begin{array}{l}\text { Initiatief van medewerker bij WP. Trainingstrajecten voor } \\
\text { leidinggevenden. Actief trainingsbeleid voor OBP. }\end{array}$ \\
\hline
\end{tabular}


Bij het wetenschappelijk personeel is het niet al te moeilijk om geschikte kandidaten aan te trekken. Promovendi worden veelal uit de eigen studentenpopulatie geworven. $\mathrm{Er}$ is eerder sprake van te weinig middelen voor $\mathrm{AiO}$ plekken dan te weinig geschikte kandidaten. Onderzoekers komen graag in Maastricht werken omdat de faculteit een hoog voorzieningsniveau kent, onderzoek wordt zo ondersteund. De onderwijslast is inmiddels op een aantrekkelijk niveau, zodat de onderzoeksmogelijkheden niet worden beperkt.

\section{Personeelsontwikkeling en loopbaanbeleid}

Wetenschappelijk personeel krijgt alleen op eigen initiatief trainingen. Slechts de leiderschapstraining voor leidinggevend WP wordt structureel aan de betrokkenen aangeboden. Het OBP heeft een bredere oriëntatie. Zij zien de hele universiteit als hun werkgever voor toekomstige carrièrestappen. Er wordt ook getracht om binnen functioneringsgesprekken ondersteuning te geven voor een verdere ontwikkeling. Voor het OBP wordt wel actief over te volgen trainingen nagedacht. Er wordt binnen de faculteit geen functieroulatie toegepast, aangezien er vooral gespecialiseerde functies zijn; wel wordt geprobeerd om in teamverband overlappende kennis op te bouwen.

Tabel 2.2

Evaluatie WP

\begin{tabular}{|c|c|c|}
\hline & Onderwijsevaluatie & Onderzoeksevaluatie \\
\hline $\mathrm{FdG}$ & Structureel door $0 \& 0$ & Vaste afspraken \\
\hline FdGW & Structureel door $0 \& 0$ & Afhankelijk van capgroep vaste afspraken \\
\hline $\mathrm{FdR}$ & $\begin{array}{l}\text { Door medewerker zelf en verzameling } \\
\text { door } 0 \& 0\end{array}$ & Vaste afspraken ( 3 jaren) \\
\hline FdEWB & Structureel door $0 \& 0$ & Verschillend per capgroep \\
\hline $\mathrm{FdCW}$ & $\begin{array}{l}\text { Terugkoppeling, maar geen structrurele } \\
\text { verzameling }\end{array}$ & Vaste afspraken, maar geen puntentelling \\
\hline $\mathrm{FdP}$ & Terugkoppeling van $0 \& 0$ & Vaste afspraken per capgroep \\
\hline
\end{tabular}

Tabel 2.I en 2.2 laten zien welke uitgangspunten die de verschillende faculteiten hanteren. Het betreft onze interpretaties van de gesprekken met de faculteiten. Tabel 2.I geeft een overzicht met betrekking tot de tijdbesteding van het wetenschappelijk personeel, vacature- en trainingsbeleid. In tabel 2.2 worden de onderwijs- en onderzoeksevaluaties kort samengevat. 


\subsection{Servicecentra}

\section{Studentenservicecentrum (SSC)}

\section{Strategie}

Het studentenservicecentrum omvat tien verschillende kleinere organisaties die voornamelijk diensten aan studenten aanbieden. Gedeeltelijk zijn deze diensten echter ook voor medewerkers toegankelijk dan wel direct op medewerkers gericht. Zo geeft het loopbaancentrum loopbaanadvies voor studenten en is er een afdeling die zich volledig op loopbaanadvies voor medewerkers richt. De afdeling communicatie en relatie is een ander voorbeeld. Deze afdeling richt zich op de werving van nieuwe studenten, maar verzorgt ook de persberichten voor zowel studentenwerving als onderzoek. Tevens wordt de interne communicatie binnen de universiteit door deze afdeling verzorgd. Het SSC is bezig om de verschillende eenheden tot een bedrijfsmatig en kostenbewust handelen te brengen. Ook is er aandacht voor onderliggende uitwisselbaarheid van banen en expertise, om zo de interne mobiliteit maar ook de breedte van de functies te bevorderen.

\section{Werving en selectie}

Het afdelingshoofd is verantwoordelijk voor het budget, het aantal formatieplaatsen en de communicatie, onder randvoorwaarden die afgesproken zijn met de directeur. Afdelingshoofden sturen de mensen aan en kunnen conform de UFO regeling zelf vacatures invullen of periodieken toekennen.

Vacatures zijn momenteel niet moeilijk in te vullen. Na één à twee jaar krijgen nieuwe medewerkers een vast dienstverband. Er is eerder sprake van te weinig dan van te veel verloop, ook omdat een aantal medewerkers hoog is ingeschaald. Hierdoor is er weinig flexibiliteit onder het personeel.

\section{Personeelsontwikkeling en loopbaanbeleid}

Het wordt een belangrijk aandachtspunt gevonden dat functioneringsgesprekken jaarlijks plaatsvinden. In deze functioneringsgesprekken wordt altijd gesproken over de eventuele wenselijkheid om bepaalde trainingen te volgen. Hierbij gaat het vooral om trainingen die zwakke plekken bijschaven. Afdelingshoofden kunnen ook gebruik maken van een coach, die inspeelt op de actuele situatie, en zo situatiegebonden feedback en training geeft. Het zou wenselijk zijn om de trainingen, die door medewerkers zijn gevolgd, systematisch vast te leggen.

Loopbaanontwikkeling wordt binnen de POP-gesprekken behandeld. Hierbij wordt gekeken naar carrières binnen het SSC, binnen de universiteit en ook naar mogelijkheden buiten de universiteit. Omdat in veel functies gespecialiseerde professio- 
nals werkzaam zijn, is de interne mobiliteit beperkt. Functieroulatie is dan ook heel gering; van de IO-I5 medewerkers die open staan voor functieroulatie zullen slechts enkelen daadwerkelijk de mogelijkheid van functieroulatie aangrijpen.

Flexibele werktijden uit de CAO waren problematisch omdat hierdoor de bereikbaarheid van bepaalde afdelingen tijdens kantooruren niet altijd gegarandeerd kon worden. Hierover zijn nu duidelijke afspraken gemaakt zodat de aan- en afwezigheidperiodes van medewerkers duidelijk in beeld gebracht zijn.

Men zou het, vanuit het SSC, wenselijk vinden als er duidelijker voor één werkgeverschap binnen de universiteit gekozen wordt. Regelingen voor het OBP zouden universiteitsbreed moeten worden vastgelegd en zo voor iedereen in gelijke mate van toepassing zijn.

\section{Universiteitsbibliotheek (UB)}

\section{Strategie}

In het UB bedrijfsplan voor de komende jaren staat resultaatgericht werken voor de bibliotheek centraal. De bibliotheek vergelijkt zich landelijk met de andere universiteitsbibliotheken van Nederland. Dit is een landelijk initiatief. Men bevindt zich in een fase waar een eerste vergelijking van managementcijfers mogelijk is. Zo kan bijvoorbeeld binnen de UB gekeken worden welk gedeelte van het budget opgaat aan training, hoeveel medewerkers men binnen de UB heeft in relatie met het aantal studenten / medewerkers van de UM en het aandeel van het UB budget in het totale UM budget.

De UB werkt inmiddels met dienstverleningsovereenkomsten. Middelen worden vanuit de faculteiten beschikbaar gesteld waaraan bepaalde overeenkomsten gekoppeld worden. Men is bezig om dit nog verder uit te werken, zodat in de toekomst faculteiten zelf kunnen beslissen welke diensten zij van de UB willen afnemen. Dit is een volledige verandering van de financiële afrekening omdat de diensten eerder geleverd werden voor een vast bedrag (bekostigingsmodel). De nieuwe dienstenovereenkomsten zijn voor faculteiten flexibeler. Ook werd de kwaliteit van de dienstverlening hieraan gekoppeld: zoals bijvoorbeeld de verwerkingssnelheid van boeken, het aantal studieplekken en de maximale wachttijd op studieplekken.

METIS wordt ook door de UB beheerd. Het doel van METIS is om de expertise en publicaties van de gehele universiteit in kaart te brengen. Dit wordt mede gebruikt om onderzoeksoutput van de universiteit te meten. 


\section{Personeelsontwikkeling en loopbaanbeleid}

De medewerkers van de UB zijn redelijk honkvast. Zij blijven er graag werken en zoeken weinig naar werk buiten de UB. Dit heeft mede te maken met de specifieke bibliothecarisopleiding. Maar ook onder medewerkers die deze opleiding niet hebben gevolgd is er geen groot verloop. Er waren verrassend weinig problemen met de internationalisering van de UM, waardoor andere eisen aan het personeel gesteld moesten worden. Van de UB medewerkers werd ineens verwacht, dat zij ook makkelijk buitenlandse studenten en medewerkers kunnen helpen.

Voor trainingen van medewerkers is er een structurele aanpak. Elk jaar zijn er verplichte trainingen voor alle medewerkers. Trainingen worden per medewerker met het afdelingshoofd besproken en vastgesteld. Het gaat vooral om taalcursussen, trainingen voor klantgericht werken, vakgerichte opleidingen gericht op automatisering of om een bibliothecarisopleiding.

Er is vanuit de bibliotheek behoefte aan een centrale inventarisatie van de gevolgde trainingen en cursussen. Ook zou het handig zijn om de "management" gegevens zoals ziekteverzuim van de eigen medewerkers gemakkelijk beschikbaar te hebben. Vanuit de cursussen die aangeboden worden binnen de UM maar ook het P\&O beleid zou men graag zien dat niet alleen op de wensen en behoeftes van de faculteiten maar ook van de servicecentra ingegaan wordt.

\section{ICT Servicecentrum (ICTS)}

\section{Strategie \& Evaluatie}

ICTS is een van de vijf servicecentra van de Universiteit Maastricht. In de afgelopen jaren zijn diverse reorganisaties van het servicecentra uitgevoerd. De resultaten van de verschillende binnen de UM uitgevoerde onderzoeken naar de kosten en de efficiëntie van de IT voorzieningen, hebben aanleiding gegeven om de organisatie van de IT opnieuw onder de loep te nemen. Om dit te doen heeft het CvB een (externe) manager aangesteld die in het inmiddels tot PISMA gedoopte project voorstellen uitwerkt voor de meest gewenste IT organisatie voor de universiteit.

\section{Werving en selectie}

Vacatures zijn niet gemakkelijk in te vullen, omdat voor vacatures eerst intern geworven moet worden, via de herplaatsingpool. Deze sollicitanten ontbreekt vaak de benodigde expertise, zeker als het om nieuwe ideeën en een nieuwe manier van aanpak gaat. $Z_{o}$ is het voor de organisatie op het ogenblik interessant om ook medewerkers te hebben, die een bedrijfsmatige aanpak van werken geleerd hebben in het bedrijfsleven. De organisatie zal namelijk in de toekomst veel meer bedrijfsmatig te 
werk gaan, waarbij de faculteiten als klanten bepaalde diensten inkopen. Hiervoor is het belangrijk om vacatures ook van buiten de UM in te vullen.

\section{Personeelsontwikkeling en loopbaanbeleid}

Men is bezig de UFO indeling van het personeel te vertalen in competenties en vakinhoudelijke eisen. Binnen de organisatie wordt gestreefd om een piramide opbouw te handhaven. Functioneringsgesprekken met medewerkers worden regelmatig gehouden, waarbij vaak ook POP's opgesteld worden. $85 \%$ van de medewerkers heeft jaarlijks een functioneringsgesprek. Binnen deze gesprekken geven de medewerkers ook aan welke trainingen zij noodzakelijk achten voor hun functie of ontwikkeling. Het management stelt prioriteiten aan de trainingen en het bijbehorend budget aan de hand van de behoeftes van de organisatie en de wensen van de medewerkers. In het trainingsbeleid wil men de vrijblijvendheid eruit halen. Het trainingsbeleid zal er meer en meer op gericht zijn om een medewerker aan alle eisen van een functieprofiel te laten voldoen. Daarnaast kan er ook trainingsbeleid gevoerd worden om personeel ontwikkelingsmogelijkheden en loopbaanperspectief te bieden. Dit moet echter wel perspectief bieden voor de organisatie. In feite komt dit neer op een tweedeling van de gevolgde trainingen: ten eerste ontwikkeltrainingen, die nieuwe vaardigheden en competenties aanleren, en ten tweede trainingen die gericht zijn op het bijhouden van bestaande competenties.

De door medewerkers gevolgde trainingen worden bijgehouden door de beherend bazen en de medewerkers zelf. Een informatiesysteem met de gevolgde trainingen en de trainingsresultaten zou hier echter meer structuur aan kunnen geven.

Beslissingen over carrières en de invulling van arbeidscontracten liggen in eerste instantie bij het afdelingshoofd, die hiervoor een voorstel voor de directie opstelt. De uiteindelijke beslissing ligt bij de directie. Het verloop van medewerkers is relatief laag. Men heeft weinig last van job-hopping. Voor het carrièrebeleid binnen het ICTS wordt binnen het afdelingshoofdoverleg gekeken welke personen voor hogere (openstaande) functies in aanmerkingen komen. Deze worden dan actief benaderd. Andere medewerkers worden ook op de hoogte gesteld van vacatures via de interne nieuwsbrief.

Flexibele werktijden liggen binnen de verantwoordelijkheid van de medewerker en de afspraken binnen de groep. Het is een van de arbeidsvoorwaarden waardoor de UM aantrekkelijk is voor IT'ers.

Functieroulatie vindt alleen plaats waar dit mogelijk is. Er wordt wel gestreefd om medewerkers nieuwe uitdagingen aan te laten gaan. Ook kan een kortstondige functieroulatie (enkele dagen) een verbreding en verdieping van de kennis van medewerkers met zich meebrengen. Zo kan een helpdeskmedewerker die een aantal keren bij 
verschillende andere afdelingen meewerkt veel duidelijker gerichte vragen stellen, uit eigen ervaring, om problemen van klanten op te lossen.

\section{Administratief Servicecentrum (ASC)}

\section{Strategie}

Het administratief service centrum - samengevoegd in de huidige samenstelling in oktober 2000 (MODI) - bestaat uit twee onderdelen: MFin en AP. Onder MFin wordt de Debiteuren en Crediteurenafdelingen, de centrale personeelsadministratie (SAP) en de Salarisadministratie samengevat. AP omvat de centrale archivering van documenten en de afdeling postzaken. Deze afdeling heeft relatief veel oudere medewerkers in dienst, die al lang aan de universiteit verbonden zijn. De afdeling documentenopslag omvat veel hoger opgeleide medewerkers, die voor de specifieke functie opgeleid zijn, terwijl postzaken geen specifieke opleidingsvereisten heeft. Binnen de financiële afdelingen is een relatief jonge opbouw van medewerkers waarvoor ook bewust gekozen is.

De doelstelling van het ASC is om binnen de dienstverlening voor de UM resultaatgericht te werken. Het ASC heeft een laag ziekteverzuim. Hiervoor wordt ook uitgebreid feedback aan de medewerkers gegeven; in de functioneringsgesprekken wordt gebruik gemaakt van $360^{\circ}$ feedback. Hierbij wordt zowel onder collega's, klanten en beherend bazen een beoordeling gevraagd.

\section{Werving en selectie}

Het invullen van vacatures was een aantal jaren geleden moeilijk, omdat de toen goed draaiende economie MEAO'ers en HEAO'ers veel keuzemogelijkheden bood. Daarom werden toen ontwikkelplannen voor interne doorstroom en vervolgopleidingen gemaakt. In de huidige (slechtere) economische situatie is het invullen van vacatures makkelijker. Toch blijken sollicitanten voor functies binnen het ASC een duidelijk ander profiel te hebben dan sollicitanten voor soortgelijke functies in het bedrijfsleven. Ook hier wil men met indirecte werving experimenteren.

\section{Personeelsontwikkeling en loopbaanbeleid}

Trainingen en opleidingen worden gegeven voor zover er behoefte bestaat en zijn niet budgetgebonden. Elk jaar zijn er bepaalde speerpunten in het trainingsbeleid. Zo stond 2004 in het kader van competentieontwikkeling en staat 2005 in het kader van de werving en selectie.

Met name bij de financiële afdeling is er een actief carrièrebeleid. Dit komt mede door hun behoefte aan een loopbaanbeleid (jongere medewerkers). Ook is er door het carrièrebeleid de nodige flexibiliteit in de organisatie. Zo zijn er carrièrepaden 
geïntroduceerd die het mogelijk maken om MEAO'ers door te laten stromen naar hogere HEAO functies, waarbij tegelijkertijd een opleiding HEAO gevolgd wordt. HEAO'ers wordt een ontwikkelingsmogelijkheid richting accountant of controller aangeboden, zodat deze zich ook voor de externe arbeidsmarkt kunnen kwalificeren. Het is een duidelijke doelstelling om het ASC als een "trainingspool" voor jonge medewerkers te profileren, waardoor zij de ervaring en certificering kunnen krijgen om binnen of buiten de universiteit naar hogere functies door te kunnen stromen. Dit geeft de organisatie als geheel flexibiliteit, omdat medewerkers door vrijwillig verloop weggaan. Ook kunnen zo goedkopere jonge medewerkers aangetrokken worden weliswaar met hogere kosten voor trainingen. Deze doorstroom is gewenst en wordt ook actief ondersteund door medewerkers tijdelijk te detacheren binnen en buiten de universiteit.

Een verder experiment is het aanwijzen van mentoren aan nieuwe HEAO'ers. De bedoeling is om zo sneller feedback aan nieuwe medewerkers te kunnen geven en de inwerktijd in de organisatie te verkorten.

Tabel 2.3 geeft een overzicht van de uitgangspunten die de servicecentra hanteren m.b.t. vacatures, trainingsbeleid en benchmarking.

Tabel 2.3

HRM beleid en Benchmarks Servicecentra

\begin{tabular}{|c|c|c|c|}
\hline & Vacatures & Trainingsbeleid & Benchmark \\
\hline SSC & Makkelijk in te vullen & Afspraken in Functioneringsgesprekken & $\begin{array}{l}\text { Streven naar bedrijfsmatig en } \\
\text { kostenbewust werken }\end{array}$ \\
\hline UB & n.v.t. & $\begin{array}{l}\text { Structurele, thematische aanpak en } \\
\text { individuele afspraken over trainingen }\end{array}$ & $\begin{array}{l}\text { Landelijke vergelijking van } \\
\text { universiteitsbibliotheken }\end{array}$ \\
\hline ICTS & $\begin{array}{l}\text { Niet snel in te vullen door interne } \\
\text { herplaatsings-procedures }\end{array}$ & $\begin{array}{l}\text { Individuele wensen van medewerkers } \\
\text { worden getoetst aan behoeftes van } \\
\text { organisatie }\end{array}$ & $\begin{array}{l}\text { Begin vergelijking met andere rekencentra } \\
\text { aan universiteiten (maar ook vergelijkbare } \\
\text { organisaties) }\end{array}$ \\
\hline ASC & Momenteel makkelijk in te vullen & $\begin{array}{l}\text { Afhankelijk van de afdeling. Afspraken in } \\
\text { functioneringsgesprekken. } 0 \text { ok structurele } \\
\text { opleidingen voor carrièrepaden. }\end{array}$ & Resultaatgericht werken. \\
\hline
\end{tabular}





\section{Inventarisatie van de beschikbare data}

In dit hoofdstuk zal een globaal overzicht worden gegeven van de binnen de UM beschikbare databronnen op basis waarvan de HRM portfolio zou kunnen worden ingevuld voor wat betreft de beschikbare human resources, het gevoerde HRM beleid en de performance indicatoren. Vanwege de vergelijkbaarheid van de informatie tussen de verschillende organisaties binnen de UM, gaat de voorkeur vanzelfsprekend uit naar informatie die op centraal niveau beschikbaar is. Daarom zal eerst in paragraaf 3.I worden ingegaan op de op centraal niveau beschikbare data. Vervolgens wordt in paragraaf 3.2 aangeven welke aanvullende data nog beschikbaar zijn op facultair niveau en bij de ondersteunende diensten.

\subsection{Data beschikbaar op centraal niveau}

\section{De beschikbare human resources}

Het SAP informatiesysteem van de UM is een waardevolle databron voor het in kaart brengen van verschillende kenmerken van de beschikbare human resources, zoals:

- de verhouding tussen wetenschappelijk personeel en OBP'ers;

- de verschillende functiegroepen binnen het WP;

- het aantal jaren dat medewerkers bij de UM in dienst zijn;

- de aard van het arbeidscontract;

- de mate waarin er in deeltijd wordt gewerkt;

- de leeftijdsopbouw en de daaraan gerelateerde vergrijzingproblematiek;

- het percentage vrouwelijke medewerkers;

- het percentage buitenlandse medewerkers.

Bovendien is het mogelijk om de informatie te verbijzonderen naar de verschillende faculteiten en ondersteunende diensten. Ook is het in principe mogelijk om op basis van het SAP informatiesysteem de informatie te verbijzonderen naar de verschillende capaciteitsgroepen. Doorgaans is dit echter weinig zinvol, omdat in dat geval relatief grote verschillen in de praktijk slechts betrekking hebben op een erg klein aantal medewerkers. 
De beschikbare informatie gaat helaas niet verder terug dan 1999. Ook is er geen informatie beschikbaar over de werkervaring van medewerkers voordat ze bij de UM zijn komen werken en ook geen informatie over de 'bestemming' van medewerkers die de UM hebben verlaten en de redenen voor dit vertrek. ${ }^{5}$ De beschikbare SAP-data maken het echter wel mogelijk om enige loopbaaninformatie te generen, die inzicht geeft in de instroom, doorstroom en uitstroom op de verschillende functieniveaus. ${ }^{6}$ Op grond hiervan is het mogelijk om over de afgelopen vijf jaar de loopbaanontwikkeling van de medewerkers van de UM te analyseren. Zowel de functiemobiliteit van het WP en het OBP, als ook de interfacultaire mobiliteit van OBP'ers, geven inzicht in het functioneren van de verticale ('promoties') en horizontale interne mobiliteitsprocessen, c.q. het carrièreverloop van werknemers. Dergelijke informatie biedt een goed startpunt voor de invulling van het HRM beleid en het analyseren van de effecten van het op departementsniveau, facultair niveau en centraal niveau gevoerde HRM beleid.

Het bestaande SAP systeem heeft de potentie om zich te ontwikkelen tot het centrale managementinformatiesysteem voor het HRM beleid van de UM. Om dit te realiseren zal een aantal stappen moeten worden gezet, gericht op:

- het verbeteren van de kwaliteit van de reeds beschikbare data;

- het verbeteren van de gebruikswaarde van de reeds beschikbare data;

- het opnemen van data met betrekking tot de personeelsontwikkeling en het gevoerde HRM beleid.

\section{HRM beleid en performance indicatoren}

Op centraal niveau is er geen goede informatiebron beschikbaar over het binnen de UM gevoerde HRM beleid. Wel kan uit het SAP informatiesysteem worden afgeleid in hoeverre UM medewerkers een arbeidsmarkttoeslag krijgen. Ook is er informatie beschikbare over de deelname aan scholingen die worden aangeboden door het loopbaancentrum en ICTS. Dit geeft echter een onvolledig beeld van de aanvullende scholing die door UM medewerkers wordt gevolgd. Om de lacunes in de beschikbare data op dit punt op te vullen, is er een enquête gehouden onder de beherend bazen van de capaciteitsgroepen en ondersteunende diensten. Hiervan zal in hoofdstuk 7 verslag worden gedaan.

Het METIS systeem van de universiteitsbibliotheek geeft op centraal niveau vergelijkbare informatie over de onderzoeksprestaties van de verschillende faculteiten en capaciteitsgroepen. Daarbij wordt een onderscheid gemaakt tussen bijdragen in boeken en

5. Momenteel worden er binnen de UM wel steeds vaker exitgesprekken gevoerd. Het zou wenselijk zijn als op basis van deze gesprekken ook systematisch informatie aan het SAP informatiesysteem wordt aangeleverd.

6. Zie ook T. Dohmen, B. Kriechel, G.A. Pfann: "Monkey Bars and Ladders: The Importance of Lateral and Vertical Job Mobility in Internal Labor Market Careers”, Journal of Population Economics, Vol. I7(2), I93-228, 2004. 
tijdschriften, waarbij een verder onderscheid gemaakt wordt tussen peer-reviewed en non-refereed tijdschriften. Dit systeem wordt door enkele faculteiten als de databron voor het meten van hun publicatie output aangehaald. Doelstelling van METIS is dan ook om dit voor de gehele universiteit mogelijk te maken. Het METIS systeem geeft echter onvoldoende inzicht in de kwaliteit van wetenschappelijke publicaties, terwijl dit voor de meeste faculteiten juist steeds belangrijker wordt. Ook is er geen koppeling mogelijk aan het personeelsnummer, waardoor het niet mogelijk is de relatie tussen de beschikbare human resources, het HRM beleid en de onderzoeksprestaties nader te onderzoeken.

In het bestaande managementsysteem is reeds informatie beschikbaar over het aantal succesvolle proefschriftstudies in de verschillende faculteiten. Daarbij wordt ook verbijzonderd naar intern en extern voorbereide promoties. Daarnaast is informatie beschikbaar over de tijdsduur van het promotietraject.

Ten aanzien van de onderwijsprestaties van de verschillende faculteiten is er op centraal niveau reeds managementinformatie beschikbaar over de ontwikkeling van studentenaantallen en het studierendement in termen van de duur van de studie, slaagpercentages voor propedeuse en doctoraal, en de uitval. Ook is er op centraal niveau informatie beschikbaar over het percentage buitenlandse studenten, uitwisselingsstudenten, e.d.

In het kader van het INK project wordt momenteel gezocht naar adequate prestatiemaatstaven voor de ondersteunende diensten. Vooralsnog zijn deze prestatiemaatstaven echter met name geoperationaliseerd door het meten van de waardering voor de geleverde diensten bij UM medewerkers en studenten. Om dergelijke subjectieve indicatoren adequaat te kunnen vaststellen, is een representatieve respons vereist onder de potentiële gebruikers van de verschillende diensten.

Ten slotte kan de in het SAP informatiesysteem beschikbare informatie over het personeelsverloop en de loopbaanontwikkelingen van zowel het OBP als het WP vanuit organisatieoogpunt beschouwd worden als 'intermediaire' prestatiemaatstaven. Hetzelfde geldt voor het ziekteverzuim. Hoewel de informatie uit het SAP systeem niet direct gebruikt kan worden, bewerkt de afdeling personeelszorg de SAP-data tot een indicator voor het ziekteverzuim, verbijzonderd naar de diverse faculteiten en ondersteunende diensten.

In 2002 is er ook een grootschalig onderzoek uitgezet naar de werkbeleving en tevredenheid van de medewerkers van de UM. In dit rapport zullen we geen gebruik maken van de gegevens van dit onderzoek, omdat de onderzoeksresultaten niet meer recent zijn. Het zou goed zijn om een beperkt aantal vragen uit dit onderzoek op te nemen in een twee- of driejaarlijkse enquête onder de UM medewerkers. 


\subsection{Beschikbare informatie bij faculteiten en ondersteunende diensten}

Op facultair niveau wordt reeds veel informatie verzameld met betrekking tot de prestaties op het terrein van onderwijs en onderzoek. Deze databronnen zouden een goede basis kunnen vormen voor het genereren van de prestatie-indicatoren voor faculteiten en capaciteitsgroepen. Wel is er hierbij sprake van separate informatiesystemen, die een vergelijkingen tussen faculteiten niet mogelijk maken.

De onderzoeksprestaties worden op meerdere faculteiten structureel gemeten. In tegenstelling tot de op centraal niveau beschikbare METIS data, wordt daarbij ook sterk gelet op de kwaliteit van de tijdschriften waarin wordt gepubliceerd. Meestal gebeurt dit op basis van de "impact factor" van de tijdschriften.

Onderwijsprestaties worden op alle faculteiten bijgehouden in de vorm van onderwijsevaluaties en onderwijsrendementen. Deze informatie wordt gebruikt ten behoeve van jaarlijkse functioneringsgesprekken en studentenevaluaties en voor het onderzoek van de capaciteitsgroepen onderwijs en onderzoek (O\&O). De informatie die beschikbaar is op basis van de onderwijsevaluaties verschilt echter tussen de faculteiten in zowel vorm als inhoud. Het gebruik van de data wordt bovendien vaak belemmerd doordat de gegevens niet eenvoudig gerelateerd kunnen worden aan de data uit de personeelsbestanden en de data met betrekking tot de onderzoeksprestaties. Een dergelijke koppeling zou overigens vrij gemakkelijk te realiseren zijn wanneer er systematisch gebruik gemaakt wordt van het personeelsnummer van medewerkers. $\mathrm{Er}$ is bij de meeste faculteiten echter ook grote terughoudendheid om onderwijs- en onderzoeksprestaties op personenniveau ter beschikking te stellen. Alleen de economisch faculteit heeft deze informatie voor ons onderzoek beschikbaar willen stellen. Ook bij deze faculteit is het koppelen van onderwijsprestaties en onderzoeksgegevens echter nog in ontwikkeling. 


\section{Enquête onder beherend bazen}

Zoals uit het vorige hoofdstuk bleek, is er op centraal niveau weliswaar personeelsinformatie beschikbaar die een indicatie geeft van de aanwezige human resources, zoals de leeftijdsopbouw van het personeel, de verhouding WP/OBP, het percentage buitenlandse stafleden, de werkervaring van medewerkers, e.d., maar geen informatie over de trainingsparticipatie van medewerkers, knelpunten in de personeelswerving en kwesties rondom personeelsverloop. Ook op het terrein van het gevoerde HRM beleid en het gebruik van de aangeboden HRM faciliteiten, is er binnen de bestaande informatiesystemen vrijwel geen informatie beschikbaar die gebuikt zou kunnen worden voor het genereren van indicatoren voor de HRM portfolio. Weliswaar zijn er verslagen van functionerings- en beoordelingsgesprekken, maar er wordt niet systematisch informatie verzameld over het aantal medewerkers waarmee deze gesprekken gevoerd worden en de frequentie van deze gesprekken.

Om deze lacunes in de beschikbare personeelsinformatie en informatie over het gevoerde HRM beleid op te vullen, is er een enquête gehouden onder de leidinggevenden ('beherend bazen') binnen de verschillende faculteiten en ondersteunende diensten. Er is gekozen voor een enquête, omdat dit de snelste weg was om aan de informatie te kunnen komen. Het ligt echter voor de hand om een deel van de gevraagde informatie in de toekomst langs administratieve weg te verzamelen.

\section{Opzet en inhoud enquête}

Om de enquêtevragen zoveel mogelijk af te stemmen op de specifieke groepen medewerkers waaraan de beherend bazen leiding geven, zijn er afzonderlijke vragenlijsten ontwikkeld voor de beherend bazen die met name leiding geven aan wetenschappelijk personeel (capgroepvoorzitters en directeuren van onderzoeksinstituten) en de beherend bazen van de ondersteunende diensten (waaronder de faculteitsbureaus). In de vragenlijsten wordt in het bijzonder ingegaan op:

- voorkeuren bij selectie;

- moeilijk vervulbare vacatures;

- personeelsverloop;

- HRM instrumenten gericht op de personeelsontwikkeling;

- prestatiedoelen;

- cursus- en trainingsparticipatie;

- kwaliteit van medewerkers; 
- belemmeringen bij het personeelsbeleid;

- managementstijl van de beherend baas.

De volledige vragenlijsten zijn te vinden in Bijlage 2.

Voordat de vragenlijsten aan de beherend bazen zijn voorgelegd, zijn eerst conceptvragenlijsten besproken met een personeelsconsulent, drie capgroepvoorzitters en twee beherend bazen van ondersteunende diensten. Uit deze gesprekken kwam onder andere naar voren dat het belangrijk is om in de vraagstelling veel oog te hebben voor de personeelsproblematiek vanuit het perspectief van de beherend bazen zelf en de specifieke problemen waarmee zij kampen. Dit heeft onder andere geleid tot het opnemen van enkele aanvullende vragen met betrekking tot de problemen die zij ondervinden in hun personeelsmanagement en de belemmeringen die zij ervaren bij hun personeelsbeleid.

De vragenlijsten zijn door Flycatcher Internet Research via internet uitgezet. De enquête is eerst aangekondigd in een brief van het College van Bestuur. Vervolgens zijn de beherend bazen op I4 april 2005 per e-mail benaderd om de enquête in te vullen. $\mathrm{Na}$ een week zijn degenen die de vragenlijst nog niet hadden beantwoord opnieuw per e-mail benaderd. Eind april is het veldwerk afgerond.

Deze on-line dataverzameling heeft een aantal belangrijke voordelen:

- de beherend bazen worden direct op hun werkplek benaderd;

- het invullen en opsturen van de vragenlijst kost de respondenten betrekkelijk weinig moeite;

- de kosten van dataverwerking zijn beperkt;

- de data worden meteen verwerkt, hetgeen de snelheid ten goed komt.

In totaal zijn II3 beherend bazen benaderd; 69 beherend bazen die met name leiding geven aan wetenschappelijk personeel (de "capaciteitsgroepen") en 44 beherend bazen van ondersteunende diensten (de "dienstverleners").?

De namen van beherend bazen zijn via de personeelsconsulenten verzameld. Op basis van de beschikbare personeelsinformatie in het SAP informatiesysteem kon door middel van de WP/OBP verhoudingen worden vastgesteld in hoeverre een bepaalde organisatie-eenheid als een capaciteitsgroep of een ondersteunende dienst moest worden getypeerd. Hierbij zijn we tegen een aantal probleempunten aangelopen, die aangeven dat de basisinfrastructuur voor een goed HRM informatiesysteem nog op een aantal punten tekortschiet:

- op centraal niveau is er geen overzicht beschikbaar van de beherend bazen binnen de organisatie;

7. In een aantal gevallen, waarbij de aard van de diensten zeer divers is (bijvoorbeeld bij de facilitaire diensten en het ASC), is er voor gekozen om bij de ondersteunende diensten ook de werkbazen te enquêteren. 
- ook op decentraal niveau is deze informatie lang niet altijd systematisch beschikbaar en soms ook onvoldoende geactualiseerd;

- de organisatie-eenheden die in het SAP systeem worden onderscheiden zijn vaak sterk verouderd: medewerkers zijn ingedeeld bij capgroepen en instituten die niet meer bestaan en capgroepen en instituten die al enkele jaren bestaan komen er niet in voor.

Vanwege de onduidelijkheid over de afbakening van de organisatie-eenheden, hebben we in de enquête gevraagd naar het aantal medewerkers waarvan de respondent beherend baas is en het personeelsverloop binnen de organisatie-eenheid. Wellicht heeft het opnemen van deze vragen, die soms enig opzoekwerk vereisen, de respons negatief beïnvloed. Afgezien van dit eventuele opzoekwerk kon de vragenlijst in circa vijftien minuten (bij de capaciteitsgroepen) en tien minuten (bij de ondersteunende diensten) ingevuld worden.

\section{Tabel 4.1}

Totaal aantal beherend bazen met aantal medewerkers en deelname aan enquête bij de capaciteitsgroepen

\begin{tabular}{|c|c|c|c|c|c|c|}
\hline & & Totaal aar & & & name aan enqu & \\
\hline & $\begin{array}{l}\text { Aantal } \\
\text { beherend } \\
\text { bazen }\end{array}$ & $\begin{array}{l}\text { Aantal } \\
\text { mede- } \\
\text { werkers } \\
\text { WP }\end{array}$ & $\begin{array}{l}\text { Aantal } \\
\text { medewerkers } \\
\text { OBP }\end{array}$ & $\begin{array}{l}\text { Aantal } \\
\text { beherend } \\
\text { bazen }\end{array}$ & $\begin{array}{l}\text { Aantal } \\
\text { mede- } \\
\text { werkers WP }\end{array}$ & $\begin{array}{l}\text { Aantal } \\
\text { mede- } \\
\text { werkers OBP }\end{array}$ \\
\hline FdAW & 3 & 48 & 13 & 1 & 10 & 2 \\
\hline $\mathrm{FdCW}$ & 5 & 101 & 17 & 4 & 64 & 7 \\
\hline FdEWB & 9 & 261 & 47 & 5 & 115 & 29 \\
\hline $\mathrm{FdG}$ & 32 & 490 & 185 & 8 & 269 & 172 \\
\hline FdGW & 10 & 329 & 112 & 5 & 160 & 54 \\
\hline $\mathrm{FdP}$ & 2 & 107 & 15 & 1 & 78 & 12 \\
\hline $\mathrm{FdR}$ & 7 & 163 & 24 & 1 & 14 & 0 \\
\hline UCM & 1 & 7 & 10 & 0 & 0 & 0 \\
\hline Totaal & 69 & 1.506 & 423 & 25 & 710 & 276 \\
\hline
\end{tabular}

Tabel 4.I geeft een overzicht van de respons op de enquête onder de beherend bazen van de capaciteitsgroepen. Van de 69 aangeschreven capgroepvoorzitters hebben slechts 25 de enquête ingevuld. Hierdoor is het helaas niet mogelijk om de uitkomsten van de enquête te verbijzonderen naar de verschillende faculteiten. Door de geringe respons is het ook niet mogelijk om relaties te leggen tussen het gevoerde HRM beleid en de prestaties van de verschillende organisatie-eenheden. De beherend bazen die de enquête wel hebben ingevuld zijn tezamen verantwoordelijk voor $47 \%$ van het WP en $65 \%$ van het OBP dat bij de verschillende capaciteitsgroepen werkzaam is. In hoofdstuk 7 zal verder worden ingegaan op de HRM indicatoren die uit de enquête kunnen worden gegenereerd. Deze indicatoren hebben - zoals gezegd - betrekking op de totale UM. Vanzelfsprekend geven ze ook aan welke informatie er op faculteitsni- 
veau beschikbaar kan komen, wanneer er representatieve gegevens op facultair niveau worden verzameld.

\section{Tabel 4.2}

Totaal aantal beherend bazen met aantal medewerkers en deelname aan enquêteij de ondersteunende diensten

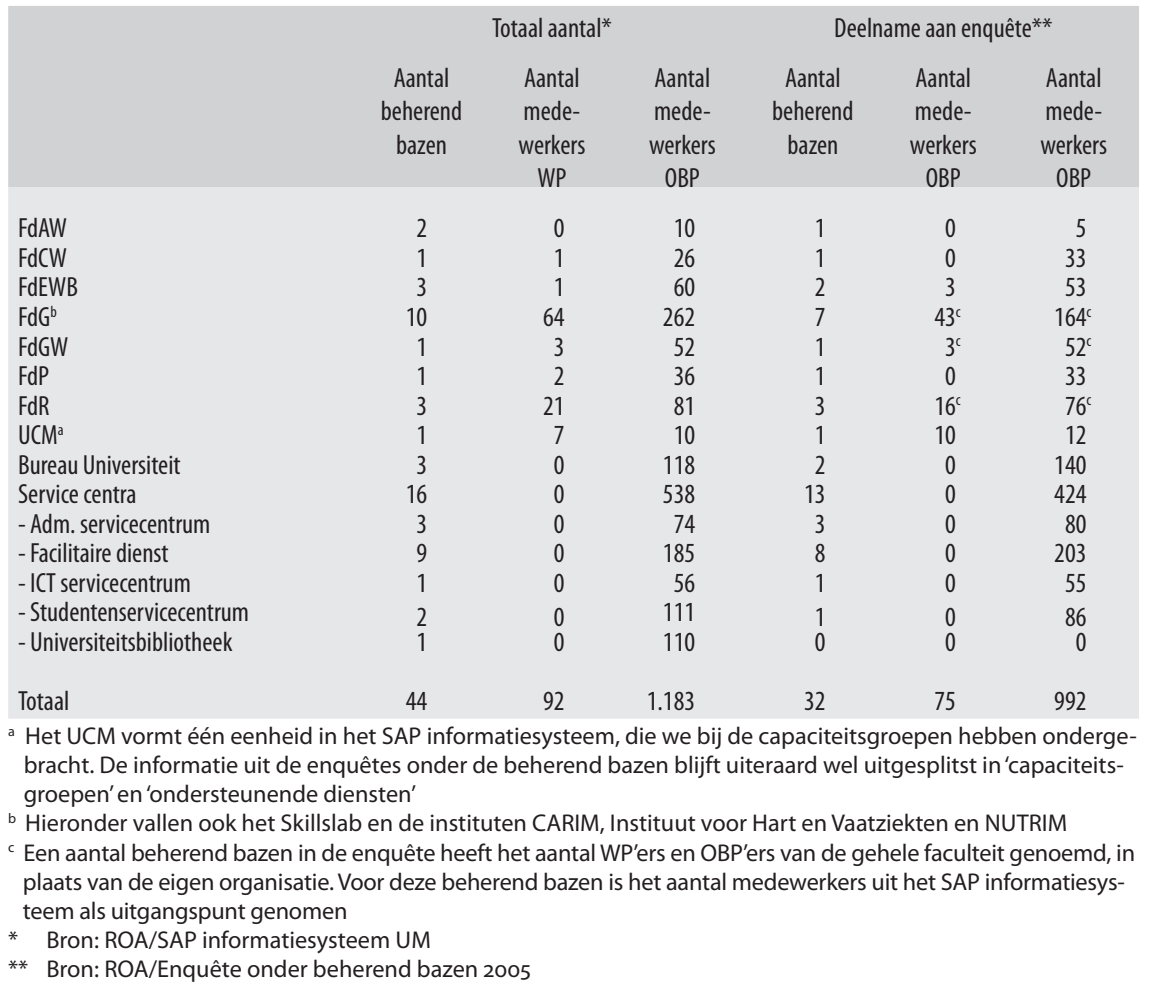

Zoals tabel 4.2 laat zien, ligt de respons op de vragenlijst onder de beherend bazen van de ondersteunende diensten verhoudingsgewijs veel hoger: 32 van de 44 beherend bazen vulden de enquête in. Deze 32 beherend bazen geven tezamen leiding aan bijna I.000 OBP'ers, dat is ruim $80 \%$ van het totaal aantal OBP'ers dat bij de ondersteunende diensten werkzaam is. Het aantal beherend bazen binnen de verschillende organisatieeenheden dat aan de enquête heeft deelgenomen, is echter te klein om op dit niveau te kunnen rapporteren. Daarom zal in hoofdstuk 7 alleen een totaalbeeld van de HRM indicatoren voor de ondersteunende diensten van de UM worden gepresenteerd. Gezien de hoge dekkingsgraad bij de servicecentra, zouden er eventueel ook HRM indicatoren kunnen worden gegenereerd die een totaalbeeld geven van de service centra. Gezien de sterk uiteenlopende aard van de verschillende servicecentra voegt dit echter weinig toe aan het nu geschetste algemene beeld voor de ondersteunende diensten. 


\section{Beschikbare Human Resources}

\section{$5.1 \quad$ Inleiding}

Het eerste terrein waarin deze HRM portfolio inzicht wil geven zijn de beschikbare human resources binnen de Universiteit Maastricht. De werknemers vormen immers het belangrijkste kapitaal van een universiteit. Veel indicatoren met betrekking tot de human resources zijn te destilleren uit het SAP informatiesysteem van de UM. Volgens dit informatiesysteem werkten er op I april 20053.204 mensen bij de Universiteit Maastricht. ${ }^{8}$ Omdat het systeem de personeelsgegevens over verschillende jaren bijhoudt, is het mogelijk om eventuele trends in de beschikbare human resources te signaleren. In dit hoofdstuk zal de huidige situatie dan ook telkens worden vergeleken met de stand van zaken vijf jaar eerder, op I april 2000, toen de Universiteit Maastricht 2.792 medewerkers telde.

Bij de beschrijving van de beschikbare human resources zal telkens een onderscheid worden gemaakt tussen de capaciteitsgroepen en de ondersteunende diensten, en daarbinnen tussen het wetenschappelijk personeel (WP) en het ondersteunend en beheers personeel (OBP). Omdat het aantal WP'ers binnen de ondersteunende diensten zeer gering is, kunnen hiervoor geen gegevens gepresenteerd worden. Daar waar dat mogelijk is, worden de gegevens ook per faculteit of servicecentrum getoond. Wanneer er in de tekst over verschillen tussen organisaties, groepen medewerkers of tijdstippen gesproken wordt, dan betreft dit statisch significante verschillen.

We zullen in dit hoofdstuk eerst aandacht besteden aan de functies die werknemers binnen de capaciteitsgroepen en de ondersteunende diensten vervullen. Daarna komt hun werkervaring binnen de Universiteit Maastricht en een aantal aspecten van hun dienstverband (zoals een vaste aanstelling en het werken in deeltijd) aan bod. Ook gaan we in op de mate waarin vergrijzing, emancipatie en internationalisering een rol spelen binnen de UM. Ten slotte geven we een overzicht van het ziekteverzuim onder het UM personeel. We sluiten dit hoofdstuk af met een overzicht van de belangrijkste indicatoren op het gebied van de beschikbare human resources. De gedachte achter deze indicatoren is dat organisaties of organisatie-eenheden op deze gebieden meetbare doelen kunnen formuleren. Hierbij moet wel worden opgemerkt dat er nog andere

8. We hebben voor deze datum gekozen omdat de enquête onder beherend bazen van de capaciteitsgroepen en de ondersteunende diensten in april 2005 heeft plaatsgevonden. 
relevante indicatoren met betrekking tot de beschikbare human resources zijn, die op dit moment niet ingevuld kunnen worden, omdat deze gegevens niet centraal geregistreerd worden. Zo is er bijvoorbeeld geen informatie in het SAP informatiesysteem beschikbaar over de door werknemers gevolgde opleidingen, hun werkervaring buiten de UM en meer in het algemeen over de inzetbaarheid van het personeel. Informatie hierover zou wellicht in de toekomst verzameld kunnen worden, om zo een vollediger beeld van de beschikbare human resources binnen de Universiteit Maastricht op te leveren.

\subsection{Functies binnen de capaciteitsgroepen en de ondersteunende diensten}

Een eerste indicatie van de beschikbare human resources wordt gevormd door de verhouding wetenschappelijk personeel en ondersteunend beheer personeel. Tabel 5.I laat zien dat $78 \%$ van het personeel in de capaciteitsgroepen tot het WP behoort. Met name bij de faculteiten FdP, FdR, FdCW en FdEWB werken relatief gezien veel WP'ers. De ondersteunende diensten hebben veel minder WP'ers in dienst. Gemiddeld genomen gaat het hier om $7 \%$ van het personeel. Opvallend is wel dat dit percentage voor de ondersteunende diensten binnen de FdR en de FdG met ongeveer $20 \%$ veel hoger ligt. Dit heeft vooral te maken met een aantal instituten dat onder deze diensten valt.

Tabel 5.1

Percentage wetenschappelijk personeel (WP), 1 april 2000 en 1 april 2005

\begin{tabular}{|c|c|c|c|c|c|c|}
\hline & \multicolumn{2}{|c|}{ Capaciteitsgroepen } & \multicolumn{2}{|c|}{ Ondersteunende diensten } & \multicolumn{2}{|c|}{ Totaal } \\
\hline & $\begin{array}{c}2000 \\
\%\end{array}$ & $\begin{array}{c}2005 \\
\%\end{array}$ & $\begin{array}{c}2000 \\
\%\end{array}$ & $\begin{array}{c}2005 \\
\%\end{array}$ & $\begin{array}{c}2000 \\
\%\end{array}$ & $\begin{array}{c}2005 \\
\%\end{array}$ \\
\hline FdAW & 66 & 79 & - & - & 62 & 68 \\
\hline $\mathrm{FdCW}$ & 78 & 86 & 14 & 4 & 64 & 70 \\
\hline FdEWB & 84 & 85 & 0 & 2 & 73 & 71 \\
\hline FdG & 54 & 73 & 48 & 20 & 53 & 55 \\
\hline FdGW & 70 & 75 & 7 & 6 & 63 & 67 \\
\hline $\mathrm{FdP}$ & 96 & 88 & 9 & 5 & 75 & 68 \\
\hline $\mathrm{FdR}$ & 84 & 87 & 2 & 21 & 69 & 64 \\
\hline UCM & & - & & & & - \\
\hline Bureau Universiteit & & & 2 & 0 & 2 & 0 \\
\hline Servicecentra & & & 0 & 0 & 0 & 0 \\
\hline - Administratief servicecentrum & & & 0 & 0 & 0 & 0 \\
\hline - Facilitaire dienst & & & 0 & 0 & 0 & 0 \\
\hline - ICT servicecentrum & & & 0 & 0 & 0 & 0 \\
\hline - Studenten servicecentrum & & & 2 & 0 & 2 & 0 \\
\hline - Universiteitsbibliotheek & & & 0 & 0 & 0 & 0 \\
\hline Totaal & 69 & 78 & 12 & 7 & 48 & 50 \\
\hline
\end{tabular}


De tabel laat ook duidelijk zien dat de verhouding tussen het WP en het OBP de afgelopen vijf jaar veranderd is. In de capaciteitsgroepen is het percentage WP'ers met 9 procentpunt toegenomen, terwijl er bij de ondersteunende diensten - relatief gezien - juist minder WP'ers zijn gaan werken. Al met al schommelt het percentage WP'ers rond de $50 \%$. Dit is iets lager dan het landelijke gemiddelde. ${ }^{9}$

In tabel 5.2 is het wetenschappelijk personeel in de capaciteitsgroepen verder verbijzonderd naar functie. Hieruit blijkt dat hoogleraren gemiddeld genomen $7 \%$ van het personeelsbestand in de capaciteitsgroepen uitmaken. Bij de FdEWB en de FdR ligt dit percentage echter twee keer zo hoog. De overige staf wordt gevormd door universitair hoofddocenten (UHDs - 9\%) en universitair docenten (UDs - I7\%). Deze laatste groep is met name goed vertegenwoordigd bij de FdP (25\%) en de FdCW (24\%). Daarnaast zijn er in de capaciteitsgroepen promovendi werkzaam; zij maken ongeveer $21 \%$ van het personeelsbestand uit. Enige voorzichtigheid is bij de interpretatie van dit laatste cijfer wel geboden, aangezien een aantal faculteiten hun promovendi tot het overig wetenschappelijk personeel rekent. Dit is bijvoorbeeld het geval bij de FdR. Het overig WP, waartoe naast promovendi ook bijvoorbeeld toegevoegde docenten worden gerekend, maakt $24 \%$ van het personeel in de capaciteitsgroepen uit.

Tabel 5.2

Functies in de capaciteitsgroepen, 1 april 2005

\begin{tabular}{|c|c|c|c|c|c|c|c|}
\hline & $\begin{array}{c}\text { Hoogleraar } \\
\%\end{array}$ & $\begin{array}{l}\text { UHD } \\
\%\end{array}$ & $\begin{array}{l}\text { UD } \\
\%\end{array}$ & $\begin{array}{c}\text { Promovendus } \\
\%\end{array}$ & $\begin{array}{c}\text { Overig WP } \\
\%\end{array}$ & $\begin{array}{l}\text { OBP } \\
\%\end{array}$ & $\begin{array}{c}\text { Totaal } \\
\%\end{array}$ \\
\hline FdAW & 10 & 8 & 12 & 31 & 18 & 21 & 100 \\
\hline $\mathrm{FdCW}$ & 5 & 11 & 24 & 14 & 31 & 14 & 100 \\
\hline FdEWB & 15 & 11 & 15 & 19 & 25 & 15 & 100 \\
\hline $\mathrm{FdG}$ & 4 & 9 & 16 & 21 & 22 & 27 & 100 \\
\hline FdGW & 4 & 6 & 18 & 24 & 22 & 25 & 100 \\
\hline $\mathrm{FdP}$ & 4 & 6 & 25 & 43 & 9 & 12 & 100 \\
\hline $\mathrm{FdR}$ & 14 & 10 & 21 & 1 & 42 & 13 & 100 \\
\hline UCM & - & - & - & - & - & - & - \\
\hline Totaal & 7 & 9 & 17 & 21 & 24 & 22 & 100 \\
\hline
\end{tabular}

Binnen de ondersteunende diensten komt een veelvoud aan functies voor. Omdat het niet mogelijk is deze functies op een overzichtelijke manier te groeperen, is in tabel 5.3 een overzicht te zien van het percentage OBP'ers naar salarisschaal. Deze schalen geven inzicht in het niveau waarop de functies vervuld worden. Zo hebben de salarisschalen 8 en 9 betrekking op functies op HBO niveau, terwijl salarisschaal ro en hoger hoort bij een functie op academisch niveau.

9. Landelijk ligt het percentage WP'ers op 54\% (stand van zaken op 3I december 2004, Wetenschappelijk Onderwijs Personeelsinformatie VSNU). Dit percentage is gebaseerd op fte's. 
Tabel 5.3

Percentage OBP'ers naar salarisschaal in de ondersteunende diensten, 1 april 2005

$\begin{array}{lccc} & & & \\ & \text { Schaal } 1-7 & \text { Schaal } 8 \text { of } 9 & \text { Schaal } 10+ \\ & \% & \% & \\ & & & - \\ \text { FdAW } & & - & 31 \\ \text { FdCW } & 39 & 31 & 35 \\ \text { FdEWB } & 28 & 37 & 16 \\ \text { FdG } & 53 & 31 & 37 \\ \text { FdGW } & 39 & 25 & 31 \\ \text { FdP } & 39 & 31 & 38 \\ \text { FdR } & 46 & 16 & 65 \\ \text { Bureau Universiteit } & 22 & 13 & 27 \\ \text { Service centra } & 44 & 30 & 14 \\ \text { - Administratief servicecentrum } & 43 & 43 & 54 \\ \text { - Facilitaire dienst } & 67 & 16 & 37 \\ \text { - ICT servicecentrum } & 7 & 39 & 26 \\ \text { - Studenten servicecentrum } & 23 & 40 & 30 \\ \text { - Universiteitsbibliotheek } & 47 & 27 & \\ \text { Totaal } & & & \\ & 42 & 27 & \end{array}$

\section{Tabel 5.4}

Percentage WP'ers en OBP'ers in salarisschaal 10 en hoger, 1 april 2000 en 1 april 2005

\begin{tabular}{|c|c|c|c|c|c|c|}
\hline & \multirow{2}{*}{\multicolumn{3}{|c|}{ Capaciteitsgroepen }} & & \multirow{2}{*}{\multicolumn{2}{|c|}{$\begin{array}{l}\text { Ondersteunende diensten } \\
\text { OBP }\end{array}$}} \\
\hline & & & & & & \\
\hline & $\begin{array}{c}2000 \\
\%\end{array}$ & $\begin{array}{c}2005 \\
\%\end{array}$ & $\begin{array}{c}2000 \\
\%\end{array}$ & $\begin{array}{c}2005 \\
\%\end{array}$ & $\begin{array}{l}2000 \\
\%\end{array}$ & $\begin{array}{c}2005 \\
\%\end{array}$ \\
\hline FdAW & 100 & 100 & - & - & - & - \\
\hline $\mathrm{FdCW}$ & 100 & 100 & - & - & - & 31 \\
\hline FdEWB & 100 & 100 & 4 & 15 & 29 & 35 \\
\hline $\mathrm{FdG}$ & 100 & 100 & 8 & 12 & 23 & 16 \\
\hline FdGW & 100 & 100 & 5 & 10 & 38 & 37 \\
\hline $\mathrm{FdP}$ & 100 & 100 & - & - & - & 31 \\
\hline $\mathrm{FdR}$ & 100 & 100 & 19 & 8 & 48 & 38 \\
\hline UCM & & - & & - & & \\
\hline Bureau Universiteit & & & & & 47 & 65 \\
\hline Servicecentra & & & & & 21 & 27 \\
\hline - Administratief servicecentr. & & & & & 23 & 14 \\
\hline - Facilitaire dienst & & & & & 9 & 17 \\
\hline - ICT servicecentrum & & & & & 28 & 54 \\
\hline - Studenten servicecentrum & & & & & 27 & 37 \\
\hline - Universiteitsbibliotheek & & & & & 29 & 26 \\
\hline Totaal & 100 & 100 & 9 & 12 & 28 & 30 \\
\hline \multicolumn{7}{|c|}{$\begin{array}{l}\text { - onvoldoende waarnemingen } \\
\text { Bron: ROA/SAP informatiesyste }\end{array}$} \\
\hline \multicolumn{7}{|c|}{$\begin{array}{l}\text { Gemiddeld genomen krijgt } 42 \% \text { van het OBP in de ondersteunende diensten } \\
\text { conform salarisschaal I tot en met } 7 \text { uitbetaald. Dit zijn functies op MBO niveau } \\
\text { of lager. Vooral bij de facilitaire dienst en de FdG zijn veel OBP'ers werkzaam die }\end{array}$} \\
\hline
\end{tabular}


in deze salarisschalen vallen (respectievelijk $67 \%$ en $53 \%$ ). Daarnaast heeft $27 \%$ van het OBP een functie op HBO niveau in salarisschaal 8 of 9. Deze medewerkers zijn vooral veel bij het administratief servicecentrum (43\%) en het studenten servicecentrum $(40 \%)$ te vinden. $30 \%$ van het OBP ten slotte heeft een functie waar een salarisschaal van Io of meer bij hoort. Deze academische functies komen het meest voor bij het bureau van de universiteit $(65 \%)$ en het ICT servicecentrum (54\%).

Het percentage medewerkers in functies op academisch niveau, is overigens een goede indicator voor een kennisinstelling als de UM. In totaal werkt $62 \%$ van het personeel van de UM in een functie op academisch niveau. Uit tabel 5.4 komt duidelijk naar voren dat het OBP binnen de capaciteitsgroepen veel minder vaak een functie op academisch niveau (I2\%) heeft dan het OBP in de ondersteunende diensten (30\%). Deze laatste groep heeft dan ook veel meer een staffunctie, terwijl het OBP binnen de capaciteitsgroepen meestal directe ondersteuning geeft aan het wetenschappelijk personeel.

\subsection{Werkervaring en aard dienstverband van medewerkers}

Een andere belangrijke indicator voor de beschikbare human resources is de werkervaring van medewerkers. In het SAP systeem is alleen informatie opgeslagen over de werkervaring binnen de Universiteit Maastricht. Onbekend is hoeveel werkervaring medewerkers buiten de UM hebben opgedaan en waar deze werkervaring uit bestaat.

\section{Tabel 5.5}

Gemiddeld aantal dienstjaren voor WP en OBP, 1 april 2005

\begin{tabular}{|c|c|c|c|}
\hline & \multicolumn{2}{|c|}{ Capaciteitsgroepen } & \multirow{2}{*}{$\begin{array}{c}\text { Ondersteunende diensten } \\
\text { OBP } \\
\text { Gemiddelde }\end{array}$} \\
\hline & $\begin{array}{c}\text { WP } \\
\text { Gemiddelde }\end{array}$ & $\begin{array}{c}\text { OBP } \\
\text { Gemiddelde }\end{array}$ & \\
\hline FdAW & 6,9 & - & - \\
\hline $\mathrm{FdCW}$ & 7,3 & - & 11,5 \\
\hline FdEWB & 8,3 & 10,0 & 7,6 \\
\hline FdG & 9,7 & 13,3 & 10,9 \\
\hline FdGW & 7,9 & 10,1 & 11,2 \\
\hline $\mathrm{FdP}$ & 6,0 & - & 9,4 \\
\hline $\mathrm{FdR}$ & 8,6 & 7,8 & 10,4 \\
\hline UCM & - & - & \\
\hline Bureau Universiteit & & & 13,0 \\
\hline Service centra & & & 12,7 \\
\hline - Administratief servicecentrum & & & 14,0 \\
\hline - Facilitaire dienst & & & 13,0 \\
\hline - ICT servicecentrum & & & 9,7 \\
\hline - Studenten servicecentrum & & & 10,2 \\
\hline - Universiteitsbibliotheek & & & 15,3 \\
\hline Totaal & 8,4 & 11,1 & 11,7 \\
\hline
\end{tabular}


Tabel 5.5 geeft aan dat het WP in de capaciteitsgroepen gemiddeld genomen ruim acht jaar in dienst van de $\mathrm{UM}$ is. Bij de FdG is het gemiddeld aantal dienstjaren van het WP bijna tien jaar, terwijl dit bij de FdP zes jaar is. Het OBP is over het algemeen wat langer werkzaam bij de UM: ruim elf jaar. Uitschieter hier is de universiteitsbibliotheek, waar het gemiddeld aantal dienstjaren van medewerkers op ruim vijftien jaar ligt.

Wanneer werknemers lang binnen een bepaalde organisatie werkzaam zijn, dan bestaat het risico dat zij steeds meer weten en kunnen op een steeds smaller vakgebied. Dit leidt tot een steeds minder gevarieerd pakket aan ervaringen, waardoor ze niet alleen binnen de eigen organisatie minder inzetbaar zijn, maar ook het risico lopen dat ze op de externe arbeidsmarkt geen kans meer maken op een andere baan. Dit geheel aan risico's wordt ook wel ervaringsconcentratie genoemd. ${ }^{\text {Io }}$ We spreken hier van ervaringsconcentratie wanneer medewerkers langer dan tien jaar bij de UM in dienst zijn.

Tabel 5.6 laat zien dat dit voor 30\% van het WP en maar liefst $45 \%$ van het OBP geldt. Bij de servicecentra (met uitzondering van het ICT servicecentrum en het studenten servicecentrum) en het bureau van de universiteit is zelfs meer dan de helft van het OBP langer dan tien jaar in dienst van de UM.

Tabel 5.6

Percentage WP'ers en OBP'ers langer dan 10 jaar in dienst, 1 april 200 en 1 april 2005

\begin{tabular}{|c|c|c|c|c|c|c|}
\hline & \multicolumn{4}{|c|}{ Capaciteitsgroepen } & \multirow{2}{*}{\multicolumn{2}{|c|}{$\begin{array}{c}\text { Ondersteunende diensten } \\
\text { OBP }\end{array}$}} \\
\hline & \multicolumn{2}{|c|}{ WP } & \multicolumn{2}{|c|}{ OBP } & & \\
\hline & $\begin{array}{c}2000 \\
\%\end{array}$ & $\begin{array}{c}2005 \\
\%\end{array}$ & $\begin{array}{c}2000 \\
\%\end{array}$ & $\begin{array}{c}2005 \\
\%\end{array}$ & $\begin{array}{c}2000 \\
\%\end{array}$ & $\begin{array}{c}2005 \\
\%\end{array}$ \\
\hline FdAW & 17 & 25 & - & - & - & - \\
\hline $\mathrm{FdCW}$ & 30 & 29 & - & - & - & 39 \\
\hline FdEWB & 29 & 32 & 31 & 43 & 18 & 25 \\
\hline FdG & 44 & 33 & 40 & 54 & 50 & 40 \\
\hline FdGW & 40 & 26 & 44 & 41 & 45 & 44 \\
\hline $\mathrm{FdP}$ & 19 & 14 & - & - & - & 33 \\
\hline $\mathrm{FdR}$ & 33 & 34 & 41 & 17 & 52 & 36 \\
\hline UCM & & - & & - & & \\
\hline Bureau Universiteit & & & & & 59 & 53 \\
\hline Servicecentra & & & & & 46 & 50 \\
\hline - Administratief servicecentr. & & & & & 41 & 52 \\
\hline - Facilitaire dienst & & & & & 47 & 54 \\
\hline - ICT servicecentrum & & & & & 49 & 32 \\
\hline - Studenten servicecentrum & & & & & 35 & 37 \\
\hline - Universiteitsbibliotheek & & & & & 59 & 67 \\
\hline Totaal & 36 & 30 & 39 & 44 & 47 & 45 \\
\hline
\end{tabular}

Io. J.G.L. Thijssen, Ervaringsconcentratie: drempel voor kwalificatievernieuwing in de tweede loopbaanhelft, Gedrag en Organisatie, 5 (6), 428-447, 1992. 
Uit de tabel blijkt ook dat de ervaringsconcentratie onder het wetenschappelijk personeel de afgelopen 5 jaar is afgenomen: in 2000 was $36 \%$ van het WP langer dan IO jaar bij de UM in dienst, in 2005 is dit gedaald tot $30 \%$. Deze daling heeft zich met name voorgedaan bij de faculteiten Gezondheidswetenschappen, Geneeskunde en Psychologie. Daarentegen is er bij het OBP dat werkzaam is in de capaciteitsgroepen de laatste jaren sprake geweest van een relatieve toename van medewerkers met ervaringsconcentratie.

Tabel 5.7 laat de keerzijde van de medaille zien: hoeveel werknemers er juist pas sinds kort (minder dan twee jaar) bij de UM werken. Dit kan als een indicator voor de vernieuwing van het personeelsbestand worden beschouwd. Het blijkt dat iets meer dan de helft van alle WP'ers minder dan twee jaar bij de universiteit in dienst is. Bij de FdGW gaat het zelfs om 60\% van het wetenschappelijk personeel. Van de OBP'ers is ongeveer eenderde minder dan twee jaar werkzaam bij de UM. Vergeleken met vijf jaar geleden is het WP en het OBP op dit vlak ook wat meer uit elkaar gegroeid: het percentage WP'ers dat minder dan twee jaar in dienst is van de UM is licht toegenomen, terwijl het percentage OBP'ers juist wat gedaald is.

\section{Tabel 5.7}

Percentage WP'ers en OBP'ers korter dan 2 jaar in dienst, 1 april 2000 en 1 april 2005

\begin{tabular}{|c|c|c|c|c|c|c|}
\hline & \multicolumn{4}{|c|}{ Capaciteitsgroepen } & \multirow{2}{*}{\multicolumn{2}{|c|}{$\begin{array}{c}\text { Ondersteunende diensten } \\
\mathrm{OBP}\end{array}$}} \\
\hline & \multicolumn{2}{|c|}{ WP } & \multicolumn{2}{|c|}{ OBP } & & \\
\hline & $\begin{array}{l}2000 \\
\%\end{array}$ & $\begin{array}{c}2005 \\
\%\end{array}$ & $\begin{array}{c}2000 \\
\%\end{array}$ & $\begin{array}{c}2005 \\
\%\end{array}$ & $\begin{array}{c}2000 \\
\%\end{array}$ & $\begin{array}{c}2005 \\
\%\end{array}$ \\
\hline FdAW & 59 & 48 & - & - & - & - \\
\hline $\mathrm{FdCW}$ & 43 & 56 & - & - & - & 35 \\
\hline FdEWB & 52 & 48 & 39 & 26 & 57 & 38 \\
\hline FdG & 44 & 50 & 39 & 26 & 37 & 39 \\
\hline FdGW & 46 & 60 & 36 & 44 & 33 & 35 \\
\hline FdP & 69 & 56 & - & - & - & 47 \\
\hline $\mathrm{FdR}$ & 46 & 41 & 44 & 33 & 43 & 43 \\
\hline UCM & & - & & - & & \\
\hline Bureau Universiteit & & & & & 25 & 25 \\
\hline Servicecentra & & & & & 35 & 25 \\
\hline - Administratief servicecentr. & & & & & 43 & 27 \\
\hline - Facilitaire dienst & & & & & 33 & 21 \\
\hline - ICT servicecentrum & & & & & 31 & 38 \\
\hline - Studenten servicecentrum & & & & & 43 & 34 \\
\hline - Universiteitsbibliotheek & & & & & 24 & 16 \\
\hline Totaal & 48 & 52 & 41 & 34 & 36 & 31 \\
\hline
\end{tabular}

Wanneer we de cijfers van de tabellen 5.6 en 5.7 met elkaar combineren, kunnen we concluderen dat slechts I $\%$ van het wetenschappelijk personeel tussen de twee en tien jaar bij de UM werkzaam is, tegenover $24 \%$ van het OBP. Deze cijfers weerspiegelen duidelijk het duale karakter van de personeelsopbouw van het wetenschappelijk 
personeel met aan de ene kant veel onervaren medewerkers en aan de andere kant medewerkers die lange tijd bij de universiteit in dienst zijn.

\section{Tabel 5.8}

Percentage WP'ers en OBP'ers met een vast contract, 1 april 2000 en 1 april 2005

\begin{tabular}{|c|c|c|c|c|c|c|}
\hline & & Capac & roepen & & Onderste & diensten \\
\hline & & & & & & \\
\hline & $\begin{array}{c}2000 \\
\%\end{array}$ & $\begin{array}{c}2005 \\
\%\end{array}$ & $\begin{array}{c}2000 \\
\%\end{array}$ & $\begin{array}{c}2005 \\
\%\end{array}$ & $\begin{array}{c}2000 \\
\%\end{array}$ & 2005 \\
\hline FdAW & 38 & 44 & - & - & - & - \\
\hline $\mathrm{FdCW}$ & 65 & 50 & - & - & - & 100 \\
\hline FdEWB & 42 & 49 & 77 & 83 & 76 & 82 \\
\hline $\mathrm{FdG}$ & 60 & 53 & 65 & 86 & 76 & 72 \\
\hline FdGW & 50 & 37 & 57 & 62 & 91 & 81 \\
\hline FdP & 43 & 36 & - & - & - & 81 \\
\hline $\mathrm{FdR}$ & 60 & 61 & 69 & 88 & 86 & 88 \\
\hline UCM & & - & & - & & \\
\hline Bureau Universiteit & & & & & 84 & 92 \\
\hline Servicecentra & & & & & 81 & 92 \\
\hline - Administratief servicecentr. & & & & & 86 & 92 \\
\hline - Facilitaire dienst & & & & & 89 & 98 \\
\hline - ICT servicecentrum & & & & & 92 & 96 \\
\hline - Studenten servicecentrum & & & & & 69 & 78 \\
\hline - Universiteitsbibliotheek & & & & & 76 & 94 \\
\hline Totaal & 53 & 48 & 63 & 77 & 91 & 86 \\
\hline
\end{tabular}

Hoeveel medewerkers van de UM hebben nu een vast contract? Tabel 5.8 laat zien dat $48 \%$ van het WP in de capaciteitsgroepen een dienstverband voor onbepaalde tijd heeft. Bij de FdGW en de FdP hebben beduidend minder WP'ers een vast contract (ongeveer 37\%). Daarentegen heeft het merendeel van het WP bij de FdR een vast contract: $6 \mathrm{I} \%$. Bij de wetenschappelijke staf van de capaciteitsgroepen (hoogleraren, UHDs en UDs) ligt dit percentage overigens een stuk hoger; 88\% van de wetenschappelijke staf van de UM heeft een vast contract. Ook van het OBP heeft een ruime meerderheid een vaste aanstelling. Bij de capaciteitsgroepen gaat het om $77 \%$ van de OBP'ers, terwijl dit percentage bij de ondersteunende diensten $88 \%$ bedraagt. Het is opmerkelijk dat, terwijl het percentage WP'ers met een vast contract de afgelopen 5 jaar is afgenomen, het percentage OBP'ers met een vast dienstverband binnen de capaciteitsgroepen sterk is toegenomen. 
Tabel 5.9

Percentage parttime werkende WP'ers en OBP'ers, 1 april 2000 en 1 april 2005

\begin{tabular}{|c|c|c|c|c|c|c|}
\hline & \multicolumn{4}{|c|}{ Capaciteitsgroepen } & \multirow{2}{*}{\multicolumn{2}{|c|}{$\begin{array}{l}\text { Ondersteunende diensten } \\
\text { OBP }\end{array}$}} \\
\hline & \multicolumn{2}{|c|}{ WP } & \multicolumn{2}{|c|}{ OBP } & & \\
\hline & $\begin{array}{c}2000 \\
\%\end{array}$ & $\begin{array}{l}2005 \\
\%\end{array}$ & $\begin{array}{c}2000 \\
\%\end{array}$ & $\begin{array}{c}2005 \\
\%\end{array}$ & $\begin{array}{c}2000 \\
\%\end{array}$ & $\begin{array}{l}2005 \\
\%\end{array}$ \\
\hline FdAW & 32 & 23 & - & - & - & - \\
\hline $\mathrm{FdCW}$ & 31 & 38 & - & - & - & 65 \\
\hline FdEWB & 38 & 35 & 51 & 62 & 47 & 47 \\
\hline FdG & 48 & 41 & 51 & 57 & 43 & 44 \\
\hline $\begin{array}{l}\text { FdGW } \\
\text { FdP }\end{array}$ & $\begin{array}{l}43 \\
37\end{array}$ & $\begin{array}{l}33 \\
18\end{array}$ & 67 & 63 & 45 & $\begin{array}{l}48 \\
53\end{array}$ \\
\hline $\mathrm{FdR}$ & 32 & 36 & 38 & 58 & 52 & 74 \\
\hline UCM & & - & & - & & \\
\hline Bureau Universiteit & & & & & 54 & 48 \\
\hline Servicecentra & & & & & 52 & 50 \\
\hline - Administratief servicecentrum & & & & & 23 & 26 \\
\hline - Facilitaire dienst & & & & & 47 & 50 \\
\hline - ICT servicecentrum & & & & & 26 & 23 \\
\hline - Studenten servicecentrum & & & & & 77 & 71 \\
\hline - Universiteitsbibliotheek & & & & & 64 & 58 \\
\hline Totaal & 41 & 35 & 53 & 59 & 50 & 51 \\
\hline
\end{tabular}

Wanneer we de beschikbare human resources binnen de Universiteit Maastricht in kaart willen brengen, is een antwoord op de vraag of medewerkers al dan niet in deeltijd werken ook van belang. Tabel 5.9 geeft aan dat ongeveer eenderde van het wetenschappelijk personeel in de capaciteitsgroepen in deeltijd werkt. Deze parttime WP'ers werken gemiddeld genomen 20 uur per week, terwijl de gemiddelde deeltijdfactor voor alle WP'ers in de capaciteitsgroepen o,82 bedraagt. Parttime WP'ers zijn veel minder vaak te vinden bij de FdAW (23\%) en de FdP (I8\%). Het OBP werkt veel vaker in deeltijd dan het WP. 59\% van de OBP'ers in de capaciteitsgroepen en $5 \mathrm{I} \%$ van de OBP'ers in de ondersteunende diensten heeft een parttime aanstelling. Deze parttimers werken over het algemeen wel iets meer uren dan de WP'ers met een deeltijdaanstelling, zo'n 23 uur per week. Bij de FdR en het studenten servicecentrum werken overigens relatief veel OBP'ers in deeltijd, terwijl dit bij het administratief servicecentrum en het ICT servicecentrum juist minder vaak het geval is. Ten slotte blijkt uit de tabel dat er vergeleken met vijf jaar geleden niet zoveel veranderd is. Binnen de capaciteitsgroepen heeft het WP wat minder vaak een deeltijd aanstelling dan in 2000 en is het percentage OBP'ers dat parttime werkt licht gestegen.

\subsection{Vergrijzing en emancipatie}

Naast functie, werkervaring en aard van het dienstverband, zeggen de achtergrondkenmerken van medewerkers ook iets over de beschikbare human resources. Tabel 
5.IO geeft een overzicht van de gemiddelde leeftijd van WP'ers en OBP'ers. Het valt op dat het wetenschappelijk personeel gemiddeld genomen een paar jaar jonger is dan het ondersteunend en beheers personeel. OBP'ers werkzaam bij de facilitaire dienst zijn het oudst: zij zijn gemiddeld 47 jaar.

\section{Tabel 5.10}

Gemiddelde leeftijd van WP'ers en OBP'ers, 1 april 2005

\begin{tabular}{|c|c|c|c|}
\hline & Capaci & epen & Ondersteunende diensten \\
\hline & $\begin{array}{l}\text { WP } \\
\text { Gemiddelde } \\
\text { jaren }\end{array}$ & $\begin{array}{l}\text { OBP } \\
\text { Gemiddelde } \\
\text { jaren }\end{array}$ & $\begin{array}{c}\text { OBP } \\
\text { Gemiddelde } \\
\text { jaren }\end{array}$ \\
\hline FdAW & 37,1 & - & - \\
\hline $\mathrm{FdCW}$ & 40,6 & - & 44,2 \\
\hline FdEWB & 37,3 & 39,1 & 39,3 \\
\hline $\mathrm{FdG}$ & 40,6 & 44,1 & 39,6 \\
\hline FdGW & 37,1 & 39,4 & 43,7 \\
\hline FdP & 34,1 & - & 39,4 \\
\hline $\mathrm{FdR}$ & 39,7 & 38,8 & 42,4 \\
\hline UCM & - & - & \\
\hline Bureau Universiteit & & & 44,8 \\
\hline Service centra & & & 44,0 \\
\hline - Administratief servicecentr. & & & 43,1 \\
\hline - Facilitaire dienst & & & 47,0 \\
\hline - ICT servicecentrum & & & 39,5 \\
\hline - Studenten servicecentrum & & & 41,2 \\
\hline - Universiteitsbibliotheek & & & 44,8 \\
\hline Totaal & 38,6 & 41,2 & 42,6 \\
\hline
\end{tabular}

Belangrijker nog dan de gemiddelde leeftijd is het percentage medewerkers dat ouder is dan 55 jaar. Deze medewerkers zullen immers in de komende jaren met (vervroegd) pensioen gaan en - bij een gelijkblijvende werkgelegenheid - vervangen moeten worden. Tabel 5.II laat zien dat er sprake is van een toenemende vergrijzing van het personeelsbestand van de UM. Het percentage medewerkers dat ouder is dan 55 jaar is in vijf jaar tijd bijna verdubbeld. Op I april 2005 was II\% van het WP in de capaciteitsgroepen ouder dan 55 jaar. Bij de FdG gaat het zelfs om $17 \%$ van het wetenschappelijk personeel. De jongste faculteiten FdCW en de FdP hebben minder last van vergrijzing; hier is maar $5 \%$ van het wetenschappelijk personeel ouder dan 55 jaar.

Ook het OBP van de UM vergrijst. I3\% van het OBP, zowel in de capaciteitsgroepen als in de ondersteunende diensten, is ouder dan 55 jaar. Bij de facilitaire dienst werken de meeste ouderen: $27 \%$ van het OBP is ouder dan 55 jaar. 
Tabel 5.11

Percentage WP'ers en OBP'ers ouder dan 55 jaar, 1 april 2000 en 1 april 2005

\begin{tabular}{|c|c|c|c|c|c|c|}
\hline & \multicolumn{4}{|c|}{ Capaciteitsgroepen } & \multirow{2}{*}{\multicolumn{2}{|c|}{$\begin{array}{l}\text { Ondersteunende diensten } \\
\text { OBP }\end{array}$}} \\
\hline & \multicolumn{2}{|c|}{ WP } & \multicolumn{2}{|c|}{ OBP } & & \\
\hline & $\begin{array}{l}2000 \\
\%\end{array}$ & $\begin{array}{c}2005 \\
\%\end{array}$ & $\begin{array}{c}2000 \\
\%\end{array}$ & $\begin{array}{l}2005 \\
\%\end{array}$ & $\begin{array}{l}2000 \\
\%\end{array}$ & $\begin{array}{c}2005 \\
\%\end{array}$ \\
\hline FdAW & 0 & 13 & - & - & - & - \\
\hline $\mathrm{FdCW}$ & 0 & 5 & - & - & - & 8 \\
\hline FdEWB & 3 & 7 & 4 & 6 & 2 & 8 \\
\hline FdG & 11 & 17 & 6 & 19 & 4 & 9 \\
\hline FdGW & 5 & 10 & 7 & 12 & 7 & 12 \\
\hline $\mathrm{FdP}$ & 5 & 5 & - & - & - & 8 \\
\hline $\mathrm{FdR}$ & 5 & 12 & 9 & 4 & 14 & 9 \\
\hline UCM & & - & & - & & \\
\hline Bureau Universiteit & & & & & 17 & 13 \\
\hline Servicecentra & & & & & 8 & 16 \\
\hline - Administratief servicecentr. & & & & & 7 & 12 \\
\hline - Facilitaire dienst & & & & & 14 & 27 \\
\hline - ICT servicecentrum & & & & & 3 & 2 \\
\hline - Studenten servicecentrum & & & & & 8 & 11 \\
\hline - Universiteitsbibliotheek & & & & & 5 & 16 \\
\hline Totaal & 6 & 11 & 6 & 13 & 9 & 13 \\
\hline
\end{tabular}

Tabel 5.12

Percentage vrouwelijke WP'ers en OBP'ers, 1 april 2000 en 1 april 2005

\begin{tabular}{|c|c|c|c|c|c|c|}
\hline & \multicolumn{4}{|c|}{ Capaciteitsgroepen } & \multirow{2}{*}{\multicolumn{2}{|c|}{$\begin{array}{c}\text { Ondersteunende diensten } \\
\text { OBP }\end{array}$}} \\
\hline & \multicolumn{2}{|c|}{ WP } & \multicolumn{2}{|c|}{ OBP } & & \\
\hline & $\begin{array}{c}2000 \\
\%\end{array}$ & $\begin{array}{c}2005 \\
\%\end{array}$ & $\begin{array}{c}2000 \\
\%\end{array}$ & $\begin{array}{c}2005 \\
\%\end{array}$ & $\begin{array}{l}2000 \\
\%\end{array}$ & $\begin{array}{l}2005 \\
\%\end{array}$ \\
\hline FdAW & 23 & 17 & - & - & - & - \\
\hline $\mathrm{FdCW}$ & 33 & 55 & - & - & - & 65 \\
\hline FdEWB & 19 & 22 & 88 & 75 & 69 & 75 \\
\hline $\mathrm{FdG}$ & 30 & 39 & 69 & 69 & 57 & 60 \\
\hline FdGW & 49 & 60 & 69 & 72 & 62 & 67 \\
\hline FdP & 34 & 48 & - & - & - & 64 \\
\hline FdR & 43 & 41 & 88 & 92 & 79 & 77 \\
\hline UCM & & - & & - & & \\
\hline Bureau Universiteit & & & & & 51 & 59 \\
\hline Servicecentra & & & & & 48 & 47 \\
\hline - Administratief servicecentrum & & & & & 46 & 34 \\
\hline - Facilitaire dienst & & & & & 40 & 44 \\
\hline - ICT servicecentrum & & & & & 26 & 23 \\
\hline - Studenten servicecentrum & & & & & 56 & 61 \\
\hline - Universiteitsbibliotheek & & & & & 60 & 62 \\
\hline Totaal & 33 & 42 & 72 & 72 & 53 & 57 \\
\hline
\end{tabular}


Tabel 5.I2 laat zien hoe het gesteld is met de verhouding tussen het aantal mannen en vrouwen dat werkzaam is aan de universiteit. Van het WP werkzaam in de capaciteitsgroepen is $42 \%$ vrouw. Ten opzichte van 2000 , toen nog slechts eenderde van het WP vrouw was, is dit percentage flink toegenomen. Vooral bij de FdGW werken veel vrouwelijke wetenschappers: 60\%. De FdEWB en de FdAW blijven met respectievelijk $22 \%$ en $17 \%$ vrouwelijke WP'ers achter. Van het OBP is de meerderheid vrouw. Met name bij de FdR werken veel vrouwen in ondersteunende functies. Het administratief servicecentrum en het ICT servicecentrum daarentegen hebben relatief weinig vrouwelijke medewerkers. Alles bij elkaar genomen springt de Universiteit Maastricht overigens boven de andere universiteiten uit. Landelijk is het percentage vrouwen werkzaam bij universiteiten namelijk 4I\%, terwijl dit bij de UM op 52\% ligt.

Tabel 5.I3 laat zien dat het percentage vrouwelijke WP'ers binnen de capaciteitsgroepen duidelijk afneemt met de hoogte van de functie. Van de hoogleraren is slechts $3 \%$ vrouw, terwijl een kwart van de universitair hoofddocenten en eenderde van de universitair docenten vrouw is. Bij promovendi ligt het percentage vrouwen met $60 \%$ nog hoger. Vergeleken met 2000, is met name het percentage vrouwelijke UHDs flink gestegen (van I4\% naar 25\%). Het percentage vrouwelijke hoogleraren en UDs is de afgelopen vijf jaar niet veel veranderd.

\section{Tabel 5.13}

Percentage vrouwelijke WP' ers in de capaciteitsgroepen naar functie, 1 april 2005

$\begin{array}{lc} & \% \\ \text { Hoogleraar } & 3 \\ \text { UHD } & 25 \\ \text { UD } & 32 \\ \text { Promovendus } & 60 \\ \text { Overig WP } & 51 \\ \text { Totaal } & 42 \\ \text { Bron: ROA/SAP informatiesysteem UM } & \end{array}$

\subsection{Internationalisering}

De Universiteit Maastricht profileert zich als een internationale universiteit. Dit weerspiegelt zich niet alleen in de aantallen studenten die uit allerlei delen van de wereld komen, maar ook in het aantal medewerkers van buitenlandse afkomst. Op I april 2005 waren 67 nationaliteiten - van Australisch tot Zwitsers - in het personeelsbestand van de UM vertegenwoordigd. Tabel 5.I4 laat zien dat 20\% van de WP'ers in de capaciteitsgroepen een niet-Nederlandse nationaliteit heeft. Naast Belgen (8\%) en Duitsers ( $5 \%)$, zijn Britten, Amerikanen, Italianen, Polen, Russen, Fransen en 
Chinezen het meest vertegenwoordigd. Bij het OBP werken minder niet-Nederlanders; het gaat dan vooral om Belgische medewerkers.

Tabel 5.14

Nationaliteiten binnen de UM, 1 april 2005

\begin{tabular}{lccc} 
& \multicolumn{2}{c}{ Capaciteitsgroepen } & Ondersteunende diensten \\
& WP & OBP & OBP \\
& $\%$ & $\%$ & $\%$ \\
Nederlands & 80 & 92 & 95 \\
Belgisch & 8 & 6 & 4 \\
Duits & 5 & 1 & 0 \\
Overig Europees & 4 & 1 & 1 \\
Overig & 4 & 1 & 0 \\
Totaal & 100 & 100 & 100 \\
Bron: ROA/SAP informatiesysteem UM & & &
\end{tabular}

\section{Tabel 5.15}

Percentage WP'ers en OBP'ers met een niet-Nederlandse nationaliteit, 1 april 2000 en 1 april 2005

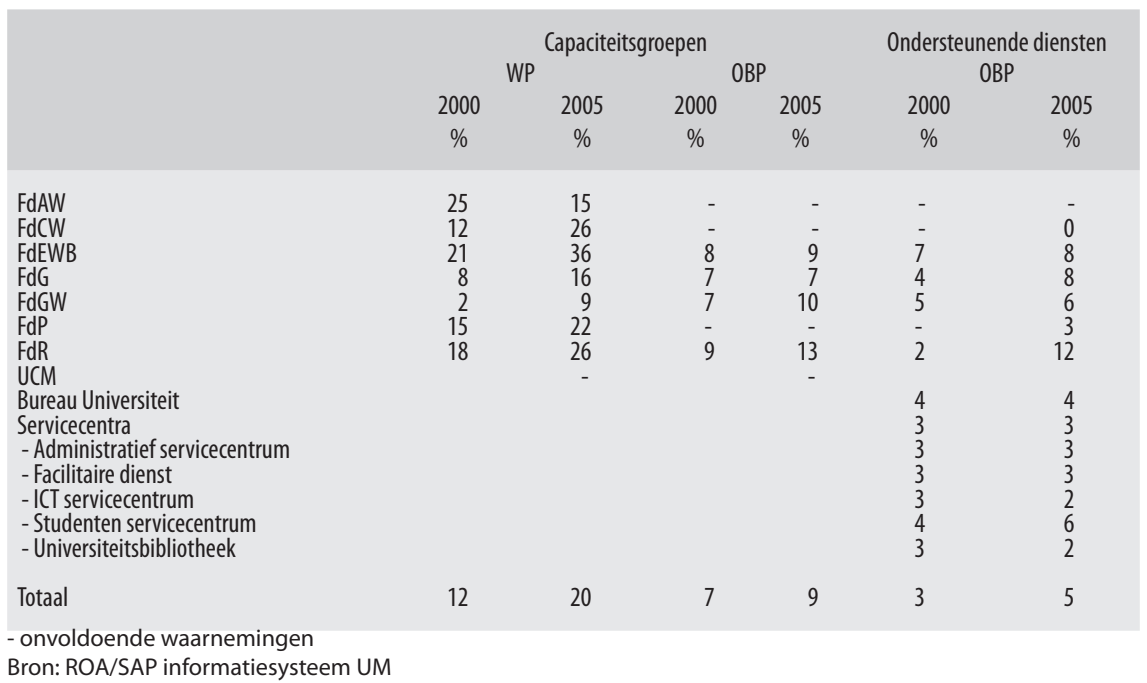

Het percentage niet-Nederlandse medewerkers is een belangrijke maat voor de internationalisering van de universiteit. Tabel 5.15 laat zien dat de internationalisering van het wetenschappelijk personeel de afgelopen vijf jaar sterk is toegenomen: het percentage niet-Nederlandse WP'ers steeg van $\mathrm{I} 2 \%$ in 2000 naar $20 \%$ in 2005 . Met name bij de FdEWB werken veel buitenlanders. Zo heeft maar liefst 36\% van het WP van deze faculteit een niet-Nederlandse nationaliteit. Bij het OBP springt de FdR eruit: zo'n I2\% van het OBP is van buitenlandse afkomst. 


\subsection{Ziekteverzuim}

Tabel 5.I6 geeft een overzicht van het ziekteverzuim onder het UM personeel. Uit de tabel blijkt dat het ziekteverzuim op de UM veel lager ligt dan het landelijk gemiddelde van 4,7\% (CBS cijfer voor 2003). Met name op de faculteiten is het ziekteverzuim zeer laag. Mogelijk is hier nog steeds sprake van een onderregistratie van het feitelijke verzuim. Opmerkelijk is het hoge ziekteverzuim onder de medewerkers van het ICTS, met name in 2003. Aangenomen mag worden dat dit samenhangt met de reorganisatie van deze ondersteunende dienst.

Tabel 5.16

Percentage ziekteverzuim, 2003-2004

$\begin{array}{lcc} & 2003 & 2004 \\ & \% & \% \\ \text { UM } & & \\ \text { FdAW } & 3,6 & 3,2 \\ \text { FdCW } & 2,7 & 2,8 \\ \text { FdEWB } & 2,9 & 4,0 \\ \text { FdG } & 2,4 & 2,2 \\ \text { FdGW } & 2,9 & 3,0 \\ \text { FdP } & 3,6 & 4,0 \\ \text { FdR } & 3,5 & 2,9 \\ \text { UCM } & 3,6 & 3,2 \\ \text { BU } & 5,7 & 3,8 \\ \text { FD } & 5,4 & 4,1 \\ \text { ICTS } & 4,9 & 4,8 \\ \text { UB } & 11,1 & 6,4 \\ \text { ASC } & 7,1 & 4,9 \\ \text { SSC } & 2,9 & 4,0 \\ & 6,1 & 2,6\end{array}$

\subsection{Samenvatting: indicatoren voor de HRM portfolio}

In dit hoofdstuk is een overzicht gegeven van de beschikbare human resources binnen de UM. We willen nu de belangrijkste indicatoren op dit terrein op een rijtje zetten. Samen vormen deze indicatoren een eerste onderdeel van de HRM portfolio. Aan de hand van deze indicatoren kunnen organisaties en/of organisatie-eenheden zich doelen stellen en de haalbaarheid van deze doelen monitoren. Tabel 5.I7 geeft een overzicht van de belangrijkste indicatoren voor zowel de capaciteitsgroepen als de ondersteunende diensten. Bovendien wordt aangegeven of er de afgelopen vijf jaar significante veranderingen hebben plaatsgevonden.

Een eerste indicator heeft te maken met de verhouding wetenschappelijk personeel en ondersteunend beheerspersoneel. Het mag duidelijk zijn dat het percentage WP'ers veel groter is in de capaciteitsgroepen $(78 \%)$ dan in de ondersteunende diensten $(7 \%)$. Hetzelfde geldt voor het aandeel academische functies, hier gemeten aan de hand 
van het percentage medewerkers dat salarisschaal io of meer uitgekeerd krijgt. Beide percentages zijn de afgelopen vijf jaar voor de capaciteitsgroepen toegenomen.

Een ander aspect van de beschikbare human resources wordt gevormd door de mate van ervaringsconcentratie, dat wil zeggen het percentage werknemers dat al langere tijd in de organisatie werkzaam is. Zowel de capaciteitsgroepen (33\%) als de ondersteunende diensten $(43 \%)$ kennen een grote groep medewerkers die langer dan tien jaar in dienst is bij de UM. Daar staat tegenover dat er ook een groot aandeel medewerkers is dat korter dan twee jaar bij de UM werkzaam is: $48 \%$ bij de capaciteitsgroepen en $34 \%$ bij de ondersteunende diensten. Naast het aantal dienstjaren zegt ook de aard van het dienstverband (vast contract, deeltijdwerk) iets over de beschikbare human resources. Het percentage medewerkers met een aanstelling voor onbepaalde tijd loopt uiteen van $54 \%$ bij de capaciteitsgroepen tot $82 \%$ bij de ondersteunende diensten. Ook parttimers zijn wat vaker te vinden bij de ondersteunende diensten (50\%) dan bij de capaciteitsgroepen (4I\%). Het percentage medewerkers dat in deeltijd werkt is de afgelopen vijf jaar overigens niet toegenomen.

De mate van vergrijzing is gemeten door te kijken naar het percentage medewerkers dat ouder is dan 55 jaar. Dit blijkt op ongeveer I2\% te liggen. Vrouwelijke medewerkers zijn met name werkzaam in de ondersteunende diensten $(57 \%)$ en minder bij de capaciteitsgroepen (48\%). Internationalisering in de vorm van medewerkers met een niet-Nederlandse nationaliteit is vooral te vinden bij de capaciteitsgroepen. Hier is $17 \%$ van de medewerkers van buitenlandse afkomst, tegen $7 \%$ bij de ondersteunende diensten. Het percentage vrouwen en niet-Nederlandse medewerkers is ten opzichte van 2000 toegenomen, zowel bij de capaciteitsgroepen als de ondersteunende diensten. Het ziekteverzuim op de UM is relatief laag. In 2004 ging hierdoor slechts 3,2\% van de werktijd verloren. Overigens ligt het ziekteverzuim bij de faculteiten op een lager niveau dan bij de ondersteunende diensten.

Zoals we in het begin van dit hoofdstuk al aangaven, zijn er nog andere indicatoren te onderscheiden die belangrijk zijn wanneer het gaat om een inventarisatie van de beschikbare human resources van een organisatie. Informatie hierover wordt op dit moment nog niet op centraal niveau binnen de UM verzameld. Het gaat dan met name om informatie over de gevolgde opleidingen van medewerkers, de werkervaring buiten de UM en de inzetbaarheid van het OBP. Een enquête onder de UM medewerkers zou op deze punten meer inzicht kunnen geven. 


\section{Tabel 5.17}

Indicatoren met betrekking tot de beschikbare human resources, 1 april 2005

\begin{tabular}{|c|c|c|c|c|}
\hline & \multicolumn{2}{|c|}{ Capaciteitsgroepen } & \multicolumn{2}{|c|}{ Ondersteunende diensten } \\
\hline & $\%$ & $\begin{array}{l}\text { Verandering } \\
\text { t.o.v. } 2000\end{array}$ & $\%$ & $\begin{array}{c}\text { Verandering } \\
\text { t.o.v. } 2000\end{array}$ \\
\hline $\begin{array}{l}\text { Verhouding WP en OBP: } \\
\% \text { WP'ers }\end{array}$ & 78 & + & 7 & - \\
\hline Academische functies: & & & & \\
\hline$\%$ medewerkers in salarisschaal 10 of hoger & 80 & + & 35 & 0 \\
\hline Ervaringsconcentratie: & & & & \\
\hline$\%$ medewerkers meer dan 10 jaar in dienst & 33 & - & 43 & 0 \\
\hline Vernieuwing: & & & & \\
\hline$\%$ medewerkers korter dan 2 jaar in dienst & 48 & 0 & 34 & - \\
\hline Zekerheid: & & & & \\
\hline$\%$ medewerkers met een vast contract & 54 & 0 & 82 & + \\
\hline Parttimers: & & & & \\
\hline$\%$ medewerkers in deeltijd & 41 & - & 50 & 0 \\
\hline Vergrijzing: & & & & \\
\hline$\%$ medewerkers ouder dan 55 & 12 & + & 13 & 0 \\
\hline Emancipatie: & & & & \\
\hline$\%$ vrouwelijke medewerkers & 48 & + & 57 & + \\
\hline Internationalisering: & & & & \\
\hline$\%$ medewerkers met niet-Nederlandse nationaliteit & 17 & + & 7 & + \\
\hline $\begin{array}{l}\text { Ziekteverzuim: } \\
\text { \% ziekteverzuim (zie cijfers tabel } 5.16 \text { ) }\end{array}$ & & & & \\
\hline $\begin{array}{l}\text { + significante toename ten opzichte van } 2000 \\
\text { o geen verandering } \\
\text { Bron: ROA/SAP informatiesysteem UM } \\
\text { Brificante afname ten opzichte van } 2000\end{array}$ & & & & \\
\hline
\end{tabular}




\section{Instroom, uitstroom en interne doorstroom}

Informatie over de loopbaanontwikkeling van het personeel is vanzelfsprekend een belangrijk element van de HRM portfolio. Hierbij gaat het om informatie over de instroom, de interne doorstroom en de uitstroom van personeel op de verschillende functieniveaus. Deze informatie geeft inzicht in wat wordt wel aangeduid als de 'omloopsnelheid' van het personeel. Informatie over de personeelsverloop kan ook inzicht geven in de mate waarin medewerkers zich oriënteren op functies buiten de UM. In hoofdstuk 3 werd reeds aangegeven dat er helaas geen informatie beschikbaar is over de 'bestemming' van de medewerkers die bij de UM vertrekken. Daarom zullen we ons in deze paragraf met name richten op de interne mobiliteitsprocessen.

Eerst zal echter in paragraaf 6.I de jaarlijkse instroom en uitstroom van personeel. Ook wordt in deze paragraaf een indicator gepresenteerd voor de 'omloopsnelheid' van het personeel. Vervolgens wordt in paragraaf 6.2 de interne doorstroom van medewerkers in kaart gebracht. Hierbij wordt gekeken naar de functiemobiliteit van het WP en het OBP en de schaalmobiliteit van het OBP. Deze informatie geeft inzicht in de verticale mobiliteit van het WP en OBP. In aansluiting daarop wordt een indicator gepresenteerd die het percentage medewerkers dat aan het eind van een salarisschaal zit in beeld brengt. Ook wordt in deze paragraaf een overzicht gegeven van de interfacultaire mobiliteit van OBP'ers. Deze informatie geeft een beeld van de feitelijke inzetbaarheid van het OBP. Vervolgens wordt in paragraaf 6.3 ingegaan op de mate waarin vacatures voor wetenschappelijk personeel intern of extern worden ingevuld. We sluiten het hoofdstuk af met een overzicht van de belangrijkste indicatoren met betrekking tot de instroom, uitstroom en interne doorstroom van het personeel.

\subsection{De instroom en uitstroom en personeel}

Zoals tabel 6.I laat zien is de groei van de werkgelegenheid bij de UM de afgelopen jaren afgenomen. Terwijl het aantal mensen dat in dienst is bij de UM in 2000 nog toenam met $5,6 \%$, is er in 2004 sprake geweest van een lichte daling van de personeelsomvang met $0,3 \%$. De instroom van nieuw personeel ligt vanzelfsprekend op een veel hoger niveau dan de netto-werkgelegenheidsgroei, omdat er ook sprake is van 'vervangingsvraag' die ontstaat door de uitstroom van vertrekkend personeel. De afgelopen 
jaren is echter ook de instroom van nieuw personeel sterk afgenomen van $19,7 \%$ in 2000 naar $13,5 \%$ in 2004 . De personeelsuitstroom is daarentegen de afgelopen jaren vrijwel niet beïnvloed door de minder gunstige werkgelegenheidsontwikkeling.

De laatste kolom van tabel 6.I geeft een indicatie van de omloopsnelheid van het personeel van de UM. ${ }^{\text {II }}$ Deze omloopsnelheid wordt gemeten als de som van de instroom en uitstroom (de bruto-stromen) gecorrigeerd van de werkgelegenheidsontwikkeling. Men spreekt hier ook wel over de 'verversingsgraad'. ${ }^{2}$ Uit deze indicator blijkt dat de omloopsnelheid van het personeel de afgelopen jaren enigszins is teruggelopen. Het is onduidelijk in hoeverre dit een meer structurele ontwikkeling aangeeft, of dat dit samenhangt met de minder gunstige conjuncturele economische ontwikkeling, waarbij de arbeidsmobiliteit op een lager niveau ligt dan in een economische hoogconjunctuur.

\section{Tabel 6.1}

Jaarlijkse instroom en uitstroom van personeel, werkgelegenheidsgroei en omloopsnelheid van het personeel*, 2000-2004

\begin{tabular}{|c|c|c|c|c|}
\hline & Instroom & Uitstroom & $\begin{array}{l}\text { Werkgelegen- } \\
\text { heidsgroei* }^{*}\end{array}$ & $\begin{array}{c}\text { Omloopsnelheid } \\
\text { personeel }^{* *}\end{array}$ \\
\hline & $\%$ & $\%$ & $\%$ & $\%$ \\
\hline 2000 & 20,8 & 15,2 & 5,6 & 30,5 \\
\hline 2001 & 18,3 & 14,6 & 3,7 & 29,3 \\
\hline 2002 & 19,4 & 14,3 & 5,1 & 28,6 \\
\hline 2003 & 14,3 & 13,0 & 1,3 & 26,0 \\
\hline 2004 & 13,4 & 13,8 & $-0,3$ & 26,7 \\
\hline
\end{tabular}

Tabel 6.2 geeft een overzicht van de gemiddelde omloopsnelheid van het personeel in de verschillende faculteiten en ondersteunende diensten in de jaren 2003 en 2004. Voor het WP is de omloopsnelheid het hoogst bij de faculteiten Geneeskunde en Gezondheidswetenschappen; voor het OBP in de faculteit Psychologie. Bij de ondersteunende diensten is de omloopsnelheid van het personeel duidelijk lager dan in de faculteiten. Allen het studentenservicecentrum vormt hierop een uitzondering. Ook laat de tabel zien dat de omloopsnelheid van het personeel de afgelopen jaren in vrijwel alle faculteiten is afgenomen.

II. Zie A. Dilger, Ökonomik betrieblicher Mitbestimmung: die wirtschaftlichen Folgen von Betriebsräten, Rainer Hampp Verlag, Mering 2002.

I2. Zie J.G.L. Thijssen, Zicht op ouderenbeleid. Van afvloeiing naar inzetbaarheid, Kluwer, Deventer, I997. 
Tabel 6.2

Gemiddelde omloopsnelheid van het personeel 2003-'04 en ontwikkeling 2000-2004*

\begin{tabular}{|c|c|c|c|c|}
\hline Faculteit & WP & Trend WP & $\mathrm{OBP}$ & Trend OBP \\
\hline FdAW & 14 & dalend & 7 & dalend \\
\hline $\mathrm{FdCW}$ & 22 & dalend & 37 & gelijk \\
\hline FdEWB & 26 & dalend & 18 & gelijk \\
\hline $\mathrm{FdG}$ & 31 & gelijk & 21 & dalend \\
\hline FdGW & 37 & gelijk & 24 & dalend \\
\hline $\mathrm{FdP}$ & 21 & dalend & 27 & stijgend \\
\hline $\mathrm{FdR}$ & 21 & dalend & 21 & gelijk \\
\hline $\mathrm{BU}$ & . & . & 9 & dalend \\
\hline ASC & . & . & 3 & dalend \\
\hline FD & . & . & 9 & dalend \\
\hline ICTS & . & . & 9 & dalend \\
\hline SSC & . & . & 35 & gelijk \\
\hline UB & & . & 16 & gelijk \\
\hline Totaal UM & 32 & gelijk & 22 & dalend \\
\hline
\end{tabular}

Tabel 6.3

Jaarlijkse uitstroom naar jaar van instroom, 1999-2004

\begin{tabular}{|c|c|c|c|c|c|c|}
\hline \multirow[t]{3}{*}{ Jaar van indiensttrede } & \multicolumn{3}{|c|}{ Uit dienst } & \multicolumn{3}{|c|}{ Nog in dienst in } \\
\hline & 1999 & 2000 & 2001 & 2002 & 2003 & 2004 \\
\hline & $\%$ & $\%$ & $\%$ & $\%$ & $\%$ & $\%$ \\
\hline (voor) 1999 & 15 & 10 & 8 & 6 & 5 & 56 \\
\hline 2000 & 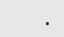 & 26 & 12 & 8 & 12 & 42 \\
\hline 2001 & . & . & 26 & 12 & 9 & 53 \\
\hline 2002 & . & . & . & 24 & 12 & 64 \\
\hline 2003 & . & . & . & 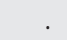 & 25 & 75 \\
\hline
\end{tabular}

Tabel 6.3 geeft een overzicht van het percentage werknemers van verschillende instroomcohorten die in een bepaald jaar uittreden. De laatste kolom geeft aan welk deel van de desbetreffende groep in 2004 nog steeds in dienst van de UM was. Van de werknemers die reeds voor oktober 1999 bij de UM in dienst zijn getreden, heeft $15 \%$ de universiteit in 1999 verlaten. In de jaren daarna neemt deze uitstroom af tot $5 \%$ in 2003. In 2004 was nog $58 \%$ van deze medewerkers in dienst van de UM. De tabel laat ook duidelijk zien dat van het personeel dat in 2000 of in de jaren daarna bij de UM is gaan werken, ongeveer een kwart binnen een jaar de UM weer heeft verlaten. Ook onder de medewerkers die nog maar twee of drie jaar bij de UM werkzaam zijn, is de uitstroom relatief hoog. Van degenen die in 2000 bij de UM zijn gaan werken is vier jaar later dan ook nog maar $45 \%$ bij de UM werkzaam. Deze cijfers verklaren ook het in hoofdstuk 5 geconstateerde duale karakter van de personeelsopbouw van de UM: 
$37 \%$ van de medewerkers is korter dan 2 jaar in dienst zijn van de UM, terwijl $43 \%$ van de medewerkers reeds langer dan io jaar bij de UM werkzaam is.

\subsection{De interne doorstroom van medewerkers}

Een belangrijk aspect van het personeelsbeleid heeft betrekking op de doorstroom van medewerkers naar andere functies binnen de organisatie. In alle organisaties is er sprake van natuurlijk verloop. Deze uitstroom geeft de mogelijkheid om de interne mobiliteit en de carrièreperspectieven binnen de organisatie te bevorderen door vrijkomende plekken binnen de organisatie op te vullen. Een dergelijke interne arbeidsmarkt versterkt de binding en loyaliteit tussen de organisatie en haar medewerkers. ${ }^{13}$ Tegenvallende interne carrièreperspectieven zijn voor goede medewerkers immers belangrijke redenen om voor een dienstverband elders te kiezen. Daar staat echter tegenover dat door de instroom van nieuwe werknemers 'vers bloed' wordt verkregen, met nieuwe ideeën en nieuwe inzichten die de organisatie scherp kunnen houden.

In deze paragraaf zal de interne mobiliteit van het personeel in kaart worden gebracht, zowel voor de universiteit als geheel, als ook voor de faculteiten en ondersteunende diensten. Daarbij vergelijken we de doorstoompercentages van werknemers die in de periode 1999-2004 in dienst zijn gebleven met de interne doorstroom van werknemers die de UM intussen hebben verlaten. Deze data zijn afkomstig uit het SAP informatiesysteem van de UM. ${ }^{14}$ Achtereenvolgens zal worden ingegaan op de interne mobiliteit van het wetenschappelijk personeel en de OBP'ers.

\section{Wetenschappelijke staf}

Tabel 6.4 geeft een overzicht van de interne doorstroom van de wetenschappelijke staf tussen de drie basisfuncties Universitaire Docent (UD), Universitaire Hoofddocent (UHD) en Hoogleraar (HGL) in de periode 1999-2004. De doorstroom van UDnaar UHD en hoogleraarposities is het grootst voor de WP'ers die in 1999 reeds bij de UM werkzaam waren en daar ook in 2004 nog werkten ( de "stayers"). Van deze groep is ruim $20 \%$ doorgestroomd naar een UHD functie, terwijl $3 \%$ van deze UD'ers zelfs is doorgestroomd naar een hoogleraarfunctie. Van de nieuw ingestroomde UD' $\operatorname{ers}^{15}$ (de "nieuwkomers") is $4 \%$ doorgestroomd naar een UHD functie. De interne functiemobiliteit voor deze instromers is logischerwijs veel lager dan voor de stayers, omdat zij niet de volledige vijf jaar in dienst van de UM zijn geweest en bovendien meestal minder werkervaring hebben dan de UD'ers die reeds langer in dienst waren. De

I3. Zie bijvoorbeeld P.B. Doeringer \& M.J. Piore, Internal Labor Markets and Manpower Analyses, Heath Lexington Books, Lexington, I97I.

I4. Uit het SAP-informatiesysteem zijn 'snapshots' gemaakt van de standcijfers op I oktober van de jaren I999 tot en met 2004 .

15. Het wetenschappelijk personeel dat na 1999 bij de UM is komen werken en binnen de onderzochte periode weer is vertrokken, is hierin niet opgenomen. 
UD'ers die tussen oktober 1999 en oktober 2004 de UM hebben verlaten (de "uitstromers") hebben voor vertrek duidelijk minder carrière gemaakt. Voor een deel is dit toe te schrijven aan de kortere tijdsperiode waarin ze intern mobiel konden zijn, maar in het algemeen zal de uitstroom ook met hun carrière te maken hebben: vaak zullen zij elders in een hogere functie zijn gaan werken, of een beter uitzicht hebben op een hogere functie, dan ze bij de UM hadden.

Bij de UHD's is bijna $20 \%$ van de stayers in de jaren $1999-2004$ doorgestroomd naar een hoogleraarpositie, tegenover 6\% van de recent ingestroomde UHD's en $4 \%$ van de uitstromers.

\section{Tabel 6.4}

Interne doorstroom van 'stayers', nieuwkomers en uitstromers voor UD'ers en UHD'ers, 1999-2004

\begin{tabular}{|c|c|c|c|c|c|}
\hline & & \multicolumn{4}{|c|}{ Doorstroom naar } \\
\hline & & UD & UHD & HGL & Overig \\
\hline \multicolumn{2}{|c|}{ Uitgangsfunctie } & $\%$ & $\%$ & $\%$ & $\%$ \\
\hline \multirow[t]{3}{*}{ UD } & Stayers & 74 & 20 & 3 & 3 \\
\hline & Nieuwkomers & 96 & 4 & 0 & 1 \\
\hline & Uitstromers & 89 & 10 & 0 & 1 \\
\hline \multirow[t]{3}{*}{ UHD } & Stayers & 0 & 79 & 20 & 1 \\
\hline & Nieuwkomers & - & 81 & 6 & - \\
\hline & Uitstromers & 0 & 96 & 4 & 0 \\
\hline
\end{tabular}

Tabel 6.5 toont de loopbaanmobiliteit van het wetenschappelijk personeel in de verschillende faculteiten. De cijfers hebben betrekking op alle functieveranderingen van zowel de stayers, nieuwkomers als uitstromers. In de economische faculteit en de faculteit der Algemene Wetenschappen is de doorstroom van universitaire docenten naar hogere functies het grootst. In vijf jaar tijd is in deze faculteiten circa $30 \%$ van de UD'ers doorgestroomd naar een UHD positie. Duidelijk lager zijn de doorstoompercentages van de Randwyck faculteiten Gezondheidswetenschappen, Psychologie en Geneeskunde. De doorstroom van UHD'ers naar een hoogleraarpositie is het hoogst bij Cultuur Wetenschappen, gevolgd door de faculteiten Algemene wetenschappen en Economie en Bedrijfskunde. Ook hier ligt de doorstroom bij de Randwyck faculteiten op een duidelijk lager niveau. 
Tabel 6.5

Interne doorstroom van 'stayers', nieuwkomers en uitstromers voor UD'ers en UHD'ers, per faculteit 1999-2004

\begin{tabular}{|c|c|c|c|c|c|}
\hline \multirow[b]{3}{*}{ Uitgangsfunctie } & \multicolumn{5}{|c|}{ Doorstroom naar } \\
\hline & & UD & UHD & HGL & Overig \\
\hline & & $\%$ & $\%$ & $\%$ & $\%$ \\
\hline \multirow[t]{7}{*}{ UD } & FdAW & 62 & 29 & 10 & 0 \\
\hline & $\mathrm{FdCW}$ & 71 & 24 & 3 & 1 \\
\hline & FdEWB & 58 & 31 & 8 & 4 \\
\hline & $\mathrm{FdG}$ & 90 & 9 & 0 & 1 \\
\hline & FdGW & 86 & 11 & 1 & 2 \\
\hline & $\mathrm{FdP}$ & 89 & 10 & 0 & 1 \\
\hline & $\mathrm{FdR}$ & 72 & 17 & 2 & 8 \\
\hline \multirow[t]{7}{*}{ UHD } & FdAW & 0 & 73 & 27 & 0 \\
\hline & $\mathrm{FdCW}$ & 0 & 68 & 32 & 0 \\
\hline & FdEWB & 0 & 74 & 25 & 2 \\
\hline & FdG & 0 & 84 & 16 & 0 \\
\hline & FdGW & 0 & 83 & 17 & 0 \\
\hline & $\mathrm{FdP}$ & 0 & 100 & 0 & 0 \\
\hline & $\mathrm{FdR}$ & 5 & 77 & 12 & 6 \\
\hline
\end{tabular}

\section{Het OBP}

Voor het OBP is gekeken naar een andere loopbaanindicator. Er zijn immers veel uiteenlopende OBP functies die moeilijk hiërarchisch gerangschikt kunnen worden. ${ }^{16}$ Daarom zal de interne doorstroom van OBP'ers in kaart gebracht worden door te kijken naar de doorstroom naar andere salarisschalen. Hierbij richten wij ons op alle onderscheiden schalen van 3 tot en met I8, waarbij alle schalen boven de $\mathrm{I} 2$ uit privacyoverwegingen samengevoegd zijn. Om de celvulling van de tabellen niet te klein te maken worden de percentages slechts voor groepen van salarisschalen gerapporteerd.

Zoals tabel 6.6 laat zien is bijna de helft van de OBP'ers in de periode 1999-2004 éen of meer schalen hoger ingeschaald. I3\% van de OBP'ers heeft zelfs twee of meer salarisschalen promotie gemaakt. Deze opwaartse schaalmobiliteit is vooral groot geweest voor degenen die oorspronkelijk in de laagste schalen (schaal 3 tot en met 5) werkzaam waren.

Bij de FdAW en FdCW zijn relatief veel OBP'ers twee of meer schalen vooruit gegaan. Daarentegen zijn met name bij de faculteiten Geneeskunde en Gezondheidswetenschappen veel minder OBP'ers zo snel in schaal gestegen. De faculteiten Economie en Psychologie zijn de faculteiten met de meeste OBP'ers die ten minste één

I6. Dit is met de invoering van het UFO systeem overigens verbeterd. Hierdoor zijn de functienamen en functieomschrijvingen binnen de hele universiteit op elkaar afgestemd. Hierdoor kunnen de verschillende functies ook aan hiërarchische niveau's gekoppeld worden. Deze data zijn echter pas vanaf 2004 beschikbaar. 
schaal naar boven zijn opgeschoven. In de faculteiten Geneeskunde en gezondheidswetenschappen zijn daarentegen relatief veel OBP'ers binnen dezelfde schaal gebleven.

\section{Tabel 6.6}

Doorstroom van OBP'ers naar hogere of lagere salarisschalen in de periode 1999-2004

\begin{tabular}{|c|c|c|c|c|c|}
\hline \multicolumn{6}{|c|}{ Doorstroom naar } \\
\hline & $\begin{array}{l}\text { lagere } \\
\text { schaal }\end{array}$ & $\begin{array}{l}\text { dezelfde } \\
\text { schaal }\end{array}$ & $\begin{array}{l}\text { één } \\
\text { schaal } \\
\text { hoger }\end{array}$ & $\begin{array}{l}\text { twee } \\
\text { schalen } \\
\text { hoger }\end{array}$ & $\begin{array}{c}\text { drie schalen } \\
\text { hoger of } \\
\text { meer }\end{array}$ \\
\hline & $\%$ & $\%$ & $\%$ & $\%$ & $\%$ \\
\hline \multicolumn{6}{|c|}{ Universiteit Maastricht } \\
\hline Schaal 3-5 & 0 & 46 & 37 & 12 & 5 \\
\hline Schaal 6-7 & 0 & 53 & 33 & 10 & 3 \\
\hline Schaal 8-9 & 1 & 53 & 35 & 8 & 3 \\
\hline Schaal $10-11$ & 1 & 54 & 38 & 6 & 1 \\
\hline Schaal 12 of hoger & 0 & 66 & 22 & 10 & 1 \\
\hline Totaal & 1 & 53 & 34 & 10 & 3 \\
\hline \multicolumn{6}{|c|}{ Faculteit der Algemene Wetenschappen } \\
\hline Schaal 3-5 & 0 & 81 & 19 & 0 & 0 \\
\hline Schaal 6-7 & 0 & 27 & 45 & 25 & 3 \\
\hline Schaal 8-9 & 2 & 51 & 29 & 6 & 12 \\
\hline Schaal $10-11$ & - & - & - & - & . \\
\hline Schaal 12 of hoger & 0 & 70 & 0 & 14 & 24 \\
\hline Totaal & 1 & 50 & 29 & 13 & 8 \\
\hline \multicolumn{6}{|c|}{ Faculteit der Culturele Wetenschappen } \\
\hline Schaal 3-5 & 0 & 25 & 32 & 32 & 11 \\
\hline Schaal 6-7 & 0 & 57 & 19 & 17 & 6 \\
\hline Schaal 8-9 & 0 & 31 & 29 & 37 & 2 \\
\hline Schaal 10-11 & 0 & 81 & 19 & 0 & 0 \\
\hline Schaal 12 of hoger & 35 & 50 & 15 & 0 & 0 \\
\hline Totaal & 3 & 52 & 23 & 18 & 4 \\
\hline \multicolumn{6}{|c|}{ Faculteit der Economische Wetenschappen } \\
\hline Schaal 3-5 & 0 & 16 & 59 & 19 & 6 \\
\hline Schaal 6-7 & 2 & 39 & 41 & 15 & 3 \\
\hline Schaal 8-9 & 2 & 45 & 40 & 13 & 0 \\
\hline Schaal 10-11 & - & 45 & 47 & 7 & 0 \\
\hline Schaal 12 of hoger & 0 & 63 & 16 & 21 & 0 \\
\hline Totaal & 1 & 39 & 42 & 14 & 2 \\
\hline \multicolumn{6}{|c|}{ Faculteit der Geneeskunde } \\
\hline Schaal 3-5 & 0 & 40 & 43 & 14 & 3 \\
\hline Schaal 6-7 & 0 & 61 & 31 & 6 & 3 \\
\hline Schaal 8-9 & 0 & 62 & 33 & 4 & - \\
\hline Schaal 10-11 & 1 & 66 & 33 & 0 & 0 \\
\hline Schaal 12 of hoger & 0 & 58 & 40 & 2 & 0 \\
\hline Totaal & 0 & 58 & 34 & 6 & 2 \\
\hline \multicolumn{6}{|c|}{ Faculteit der Gezondheidswetenschappen } \\
\hline Schaal 3-5 & 0 & 50 & 22 & 20 & 9 \\
\hline Schaal 6-7 & 0 & 66 & 28 & 3 & 3 \\
\hline Schaal 8-9 & 0 & 69 & 25 & 6 & - \\
\hline Schaal 10-11 & 0 & 67 & 32 & - & - \\
\hline Schaal 12 of hoger & 0 & 100 & 0 & 0 & 0 \\
\hline Totaal & 0 & 66 & 26 & 6 & 2 \\
\hline
\end{tabular}


Tabel 6.6 (vervolg)

Doorstroom van OBP'ers naar hogere of lagere salarisschalen in de periode 1999-2004

\begin{tabular}{|c|c|c|c|c|c|}
\hline & $\begin{array}{c}\text { lagere } \\
\text { schaal } \\
\%\end{array}$ & $\begin{array}{c}\text { Do } \\
\text { dezelfde } \\
\text { schaal } \\
\%\end{array}$ & $\begin{array}{l}\text { ar één } \\
\text { schaal } \\
\text { hoger } \\
\%\end{array}$ & $\begin{array}{l}\text { twee } \\
\text { schalen } \\
\text { hoger } \\
\%\end{array}$ & $\begin{array}{c}\text { drie schalen } \\
\text { hoger of } \\
\text { meer } \\
\%\end{array}$ \\
\hline \multicolumn{6}{|c|}{ Faculteit der Psychologie } \\
\hline Schaal 3-5 & 0 & 37 & 58 & - & - \\
\hline Schaal 6-7 & 0 & 54 & 32 & 6 & 8 \\
\hline Schaal 8-9 & 0 & 12 & 61 & 27 & 0 \\
\hline Schaal $10-11$ & 0 & 64 & 36 & 0 & 0 \\
\hline Schaal 12 of hoger & 0 & 0 & 60 & 40 & 0 \\
\hline Totaal & 0 & 45 & 41 & 10 & 4 \\
\hline \multicolumn{6}{|c|}{ Faculteit der Rechten } \\
\hline Schaal 3-5 & 0 & 25 & 60 & 13 & 2 \\
\hline Schaal 6-7 & 2 & 61 & 23 & 10 & 3 \\
\hline Schaal 8-9 & 0 & 23 & 57 & 20 & 0 \\
\hline Schaal $10-11$ & 0 & 76 & 24 & 0 & 0 \\
\hline Schaal 12 of hoger & 0 & 74 & 13 & 13 & 0 \\
\hline Totaal & 1 & 52 & 34 & 11 & 2 \\
\hline \multicolumn{6}{|c|}{ Bureau Universiteit } \\
\hline Schaal 3-5 & 0 & 20 & 55 & 17 & 8 \\
\hline Schaal 6-7 & 0 & 66 & 27 & 2 & 4 \\
\hline Schaal 8-9 & 0 & 38 & 38 & 18 & 6 \\
\hline Schaal 10-11 & 3 & 38 & 48 & 11 & 0 \\
\hline Schaal 12 of hoger & 0 & 70 & 20 & 10 & 0 \\
\hline Totaal & 1 & 51 & 36 & 11 & 2 \\
\hline \multicolumn{6}{|c|}{ Servicecentra (totaal) } \\
\hline Schaal 3-5 & 0 & 54 & 31 & 10 & 5 \\
\hline Schaal 6-7 & 0 & 37 & 42 & 18 & 3 \\
\hline Schaal 8-9 & 2 & 48 & 39 & 6 & 5 \\
\hline Schaal $10-11$ & 0 & 46 & 41 & 10 & 1 \\
\hline Schaal 12 of hoger & 0 & 64 & 25 & 11 & 0 \\
\hline Totaal & 0 & 48 & 37 & 11 & 4 \\
\hline \multicolumn{6}{|c|}{ Administratief Servicecentrum } \\
\hline Schaal 3-5 & 0 & 29 & 33 & 31 & 8 \\
\hline Schaal 6-7 & 0 & 8 & 51 & 29 & 12 \\
\hline Schaal 8-9 & - & 17 & 50 & 8 & 24 \\
\hline Schaal 10-11 & 0 & 63 & 32 & - & 0 \\
\hline Schaal 12 of hoger & 0 & 68 & 16 & 16 & 0 \\
\hline Totaal & - & 23 & 41 & 22 & 13 \\
\hline \multicolumn{6}{|c|}{ Facilitaire dienst } \\
\hline Schaal 3-5 & 0 & 66 & 27 & 4 & 4 \\
\hline Schaal 6-7 & 0 & 43 & 35 & 21 & 0 \\
\hline Schaal 8-9 & 0 & 47 & 53 & 0 & 0 \\
\hline Schaal 10-11 & 0 & 50 & 32 & 18 & 0 \\
\hline Schaal 12 of hoger & 0 & 57 & 21 & 21 & 0 \\
\hline Totaal & 0 & 58 & 31 & 8 & 2 \\
\hline \multicolumn{6}{|c|}{ ICTS } \\
\hline Schaal 3-5 & 0 & 40 & 40 & 0 & 20 \\
\hline Schaal 6-7 & 0 & 42 & 31 & 16 & 11 \\
\hline Schaal 8-9 & 0 & 49 & 40 & 11 & 0 \\
\hline Schaal 10-11 & 0 & 41 & 48 & 12 & 0 \\
\hline Schaal 12 of hoger & 0 & 100 & 0 & 0 & 0 \\
\hline Totaal & 0 & 48 & 38 & 11 & 3 \\
\hline
\end{tabular}


Tabel 6.6 (vervolg)

Doorstroom van OBP'ers naar hogere of lagere salarisschalen in de periode 1999-2004

\begin{tabular}{|c|c|c|c|c|c|}
\hline \multicolumn{6}{|c|}{ Doorstroom naar } \\
\hline & $\begin{array}{l}\text { lagere } \\
\text { schaal }\end{array}$ & $\begin{array}{l}\text { dezelfde } \\
\text { schaal }\end{array}$ & $\begin{array}{l}\text { één } \\
\text { schaal } \\
\text { hoger }\end{array}$ & $\begin{array}{l}\text { twee } \\
\text { schalen } \\
\text { hoger }\end{array}$ & $\begin{array}{c}\text { drie schalen } \\
\text { hoger of } \\
\text { meer }\end{array}$ \\
\hline & $\%$ & $\%$ & $\%$ & $\%$ & $\%$ \\
\hline \multicolumn{6}{|c|}{ Studentenservicecentrum } \\
\hline Schaal 3-5 & 0 & 22 & 48 & 7 & 22 \\
\hline Schaal 6-7 & 0 & 62 & 25 & 11 & 2 \\
\hline Schaal 8-9 & 0 & 62 & 31 & 5 & 2 \\
\hline Schaal $10-11$ & 0 & 50 & 42 & 2 & 6 \\
\hline Schaal 12 of hoger & 0 & 74 & 14 & 12 & 0 \\
\hline Totaal & 0 & 57 & 32 & 7 & 4 \\
\hline \multicolumn{6}{|c|}{ Universiteitsbibliotheek } \\
\hline Schaal 3-5 & 0 & 36 & 46 & 15 & 2 \\
\hline Schaal 6-7 & 0 & 30 & 54 & 15 & 2 \\
\hline Schaal 8-9 & 18 & 53 & 21 & 9 & 0 \\
\hline Schaal 10-11 & 1 & 42 & 44 & 13 & 0 \\
\hline Schaal 12 of hoger & 0 & 38 & 62 & 0 & 0 \\
\hline Totaal & 2 & 36 & 47 & 13 & 1 \\
\hline
\end{tabular}

Bij de ondersteunende diensten van de universiteit is er een grote diversiteit in de loopbaanontwikkeling van het OBP. De verschillende diensten hebben overigens ook een sterk verschillende functiestructuur en hebben daardoor ook mensen met sterk uiteenlopende opleidingsachtergronden en loopbaanperspectieven in dienst. Opvallend is dat het ASC relatief veel medewerkers in lagere salarisschalen naar salarisschalen promoveert die twee of meer schalen boven de oorspronkelijke schaal in 1999 liggen. Dit zou het resultaat kunnen zijn van de in hoofdstuk 2 genoemde opleidingstrajecten die ASC medewerkers volgen. Hierdoor zijn medewerkers in staat om naar een hogere functie door te stromen. Alleen in de laagste schalen ziet men een soortgelijke opwaartse mobiliteit bij het ICTS en SSC. Bij de andere servicecentra zijn er erg weinig medewerkers die in vijf jaar tijd meer dan twee salarisschalen promotie hebben gemaakt. Alleen bij de Universiteitsbibliotheek is er sprake geweest van demotie naar een lagere schaal.

\section{Stagnerende doorstroom of eindfunctie}

Tabel 6.7 geeft een overzicht van het percentage medewerkers dat aan het eind van een salarisschaal zit. Men kan verwachten dat dit vaker voorkomt bij organisaties waar veel werknemers al langer in dienst zijn en hierdoor intussen in de voor hen hoogst haalbare functie terecht zijn gekomen. Het kan echter ook een aanduiding zijn voor het stagneren van iemands loopbaanontwikkeling. Immers, wanneer er geen hogere functies vrij komen, blijven medewerkers op hun oude positie hangen. Dit kan leiden tot onvrede en het vertrek van bekwame medewerkers. 
De tabel laat zien dat $23 \%$ van het WP aan het eind van een salarisschaal zit. Bij het OBP ligt dit percentage veel hoger: $33 \%$. Dit verschil weerspiegelt het hogere percentage OBP'ers dat reeds lang bij de UM werkzaam is (zie tabel 5.6). Het percentage medewerkers dat aan het eind van een salarisschaal zit, is de afgelopen jaren overigens vrij stabiel gebleven. Met name bij het Bureau van de Universiteit zitten veel medewerkers aan het eind van een salarisschaal. Daarentegen zitten er in de jonge faculteit Psychologie relatief weinig medewerkers aan het eind van een schaal. Overigens geldt dat met name voor het WP.

Tabel 6.7

Percentage werknemers dat aan het eind van een salarisschaal zit, 1999-2004

\begin{tabular}{|c|c|c|c|c|c|c|}
\hline & $\begin{array}{c}1999 \\
\%\end{array}$ & $\begin{array}{c}2000 \\
\%\end{array}$ & $\begin{array}{c}2001 \\
\%\end{array}$ & $\begin{array}{c}2002 \\
\%\end{array}$ & $\begin{array}{c}2003 \\
\%\end{array}$ & $\begin{array}{c}2004 \\
\%\end{array}$ \\
\hline \multicolumn{7}{|c|}{ Totaal } \\
\hline FdAW & 16 & 17 & 16 & 22 & 20 & 31 \\
\hline $\mathrm{FdCW}$ & 18 & 21 & 23 & 29 & 23 & 22 \\
\hline FdEWB & 21 & 20 & 21 & 22 & 21 & 22 \\
\hline $\mathrm{FdG}$ & 36 & 33 & 32 & 33 & 29 & 31 \\
\hline FdGW & 24 & 25 & 25 & 27 & 21 & 21 \\
\hline FdP & 15 & 13 & 16 & 16 & 14 & 13 \\
\hline $\mathrm{FdR}$ & 22 & 23 & 23 & 30 & 26 & 28 \\
\hline BU & 52 & 41 & 36 & 36 & 34 & 38 \\
\hline SC & 34 & 35 & 28 & 34 & 30 & 35 \\
\hline Totaal & 29 & 28 & 27 & 30 & 26 & 28 \\
\hline \multicolumn{7}{|c|}{ WP } \\
\hline FdAW & 14 & 19 & 21 & 21 & 19 & 29 \\
\hline $\mathrm{FdCW}$ & 16 & 16 & 21 & 25 & 22 & 19 \\
\hline FdEWB & 21 & 19 & 20 & 18 & 19 & 20 \\
\hline $\mathrm{FdG}$ & 37 & 33 & 30 & 32 & 32 & 31 \\
\hline FdGW & 14 & 17 & 19 & 20 & 16 & 16 \\
\hline $\mathrm{FdP}$ & 15 & 12 & 13 & 10 & 10 & 8 \\
\hline $\mathrm{FdR}$ & 17 & 19 & 19 & 25 & 26 & 24 \\
\hline BU & . & . & . & . & . & . \\
\hline $\begin{array}{l}\text { SC } \\
\text { Totaal }\end{array}$ & $\dot{24}$ & $\dot{23}$ & $\dot{23}$ & $\dot{24}$ & $\dot{23}$ & 23 \\
\hline \multicolumn{7}{|c|}{ OBP } \\
\hline FdAW & 21 & 14 & 6 & 26 & 25 & 35 \\
\hline $\mathrm{FdCW}$ & 23 & 31 & 29 & 36 & 24 & 27 \\
\hline FdEWB & 22 & 24 & 24 & 33 & 27 & 28 \\
\hline FdG & 34 & 33 & 34 & 34 & 26 & 32 \\
\hline FdGW & 41 & 39 & 38 & 41 & 34 & 32 \\
\hline $\mathrm{FdP}$ & 16 & 17 & 27 & 30 & 21 & 25 \\
\hline $\mathrm{FdR}$ & 34 & 32 & 30 & 39 & 28 & 36 \\
\hline BU & 52 & 41 & 36 & 36 & 34 & 38 \\
\hline SC & 34 & 35 & 28 & 34 & 30 & 35 \\
\hline Totaal & 34 & 33 & 31 & 35 & 28 & 33 \\
\hline
\end{tabular}

\section{Mobiliteit van OBP'ers binnen de UM}

Het OBP is in principe inzetbaar binnen de gehele universiteit. De verschillende faculteiten en ondersteunende diensten kennen immers vergelijkbare functies. Bovendien 
wil de UM de carrièreperspectieven van het personeel verbeteren en hun employability vergroten. Vooral de kleinere faculteiten en diensten geven aan dat er veel interesse bestaat voor mobiliteitsmogelijkheden naar andere organisaties binnen de UM. Juist binnen de kleinere organisaties zijn de mogelijkheden om intern hoger op te komen immers vaak het kleinst.

Uit tabel 6.8 blijkt dat niet alleen bij de OBP'ers in de kleine faculteiten de mobiliteit naar andere organisaties binnen de UM gering is. Bij de faculteiten Psychologie en Economie is de mobiliteit van OBP'ers naar andere organisaties binnen de UM zelfs het grootst. Daarna volgen de Servicecentra en de faculteiten Cultuurwetenschappen, Rechten, Algemene wetenschappen en Gezondheidswetenschappen. ${ }^{17}$ Bij Psychologie is de relatief hoge mobiliteit van OBP'ers overigens met name een gevolg van de overplaatsing van OBP'ers naar het UCM. Bij Economie verspreiden de mobiele OBP'ers zich over de gehele organisatie. Vanuit de Geneeskundefaculteit is de mobiliteit van OBP'ers naar andere organisaties binnen de UM daarentegen zeer beperkt. Voor de OBP'ers blijken dit dan ook vaker eindplekken te zijn.

Tabel 6.8

Mobiliteit van OBP naar andere organisaties binnen de UM, 1999-2004

\begin{tabular}{|c|c|c|c|c|c|c|c|c|c|}
\hline \multirow[b]{3}{*}{ Functie in 1999} & \multicolumn{9}{|c|}{ Doorstroom naar } \\
\hline & FdAW & FdCW & FdEWB & $\mathrm{FdG}$ & FdGW & $\mathrm{FdP}$ & $\mathrm{FdR}$ & SC & BU \\
\hline & $\%$ & $\%$ & $\%$ & $\%$ & $\%$ & $\%$ & $\%$ & $\%$ & $\%$ \\
\hline FdAW & 92 & 4 & 0 & 0 & 0 & 0 & 0 & - & - \\
\hline $\mathrm{FdCW}$ & 0 & 91 & 0 & - & 0 & 0 & 0 & 3 & 5 \\
\hline FdEWB & - & 0 & 86 & 2 & - & - & 2 & 4 & 2 \\
\hline $\mathrm{FdG}$ & 0 & - & - & 97 & 2 & - & 0 & 1 & 0 \\
\hline FdGW & - & 1 & 0 & 3 & 93 & 0 & - & 2 & - \\
\hline $\mathrm{FdP}$ & 0 & 0 & 0 & - & 1 & 87 & 0 & 0 & 3 \\
\hline $\mathrm{FdR}$ & 0 & 0 & 0 & 0 & - & 0 & 92 & 8 & 0 \\
\hline SC & 0 & 0 & 0 & 0 & 1 & - & 0 & 88 & $9^{*}$ \\
\hline BU & 0 & 0 & 0 & - & 0 & - & 0 & $18^{*}$ & 81 \\
\hline
\end{tabular}

Het Bureau van de Universiteit trekt ook relatief veel OBP'ers uit de andere organisaties binnen de UM aan. Dit komt waarschijnlijk mede doordat er in het Bureau relatief veel hogere functies voorkomen. De hoge instroom vanuit de servicecentra is echter het gevolg van een reorganisatie van functies die onder de Servicecentra vielen. Ook trekken de Servicecentra vaker OBP'ers van andere faculteiten aan. De Economische faculteit is daarentegen vooral een 'stepping-stone' binnen de interne arbeidsmarkt voor OBP'ers van de UM. Deze faculteit trekt daarentegen vrijwel geen OBP'ers uit de andere organisaties binnen de UM aan.

I7. Deze mobiliteit van het Bureau van de Universiteit is louter het gevolg geweest van het verplaatsen van een deel van een afdeling naar het Servicecentrum. 


\subsection{Interne promotie of extern werven van wetenschappelijke staf}

Voor UD, UHD of hoogleraarfuncties kunnen zowel externe als interne kandidaten worden aangetrokken. Interne promoties van het eigen personeel bieden een duidelijk intern carrièreperspectief voor de eigen wetenschappelijke staf. Dit loopbaanperspectief geeft niet alleen een meer algemene prestatieprikkel, maar medewerkers zullen ook eerder geneigd zijn om te investeren in de voor de UM relevante onderzoeks- en onderwijsgebieden en een grotere loyaliteit hebben naar de eigen organisatie. De economische wetenschap heeft hierover een aantal theorieën ontwikkeld. Met name het toernooimodel laat op een aansprekende manier zien hoe de vooruitzicht op carrière een wedstrijd tussen de werknemers tot hogere productiviteit leidt. ${ }^{18}$ Dit model veronderstelt dat op de interne arbeidsmarkt werknemers met elkaar concurreren om een hogere functie. Deze concurrentiestrijd zorgt er voor dat iedereen zich optimaal inspant. De motivatie van medewerkers neemt echter af naarmate de kansen op interne promotie kleiner worden. Daar staat echter tegenover dat vooral de wetenschappelijke arbeidsmarkt in principe een zeer open arbeidsmarktsegment is. Het is daarom voor de organisatie ook aantrekkelijk om UHD's of hoogleraren van buitenaf aan te trekken. Men zou derhalve ook de academische arbeidsmarkt als één groot toernooi kunnen zien, waarin medewerkers met name een grote loyaliteit hebben naar hun vakgebied.

Tabel 6.9

Mate waarin UD, UHD en hoogleraarposities intern zijn ingevuld, 1999-2004

$\begin{array}{lccccc} & 2000 & 2001 & 2002 & 2003 & 2004 \\ & \% & \% & \% & \% & \% \\ \text { UD } & 23 & 35 & 24 & 33 & 44 \\ \text { UHD } & 83 & 83 & 82 & 60 & 72 \\ \text { HGL }^{*} & 36 & 43 & 30 & 55 & 73\end{array}$

* Het gaat hier jaarlijks om een gering aantal vacatures

Bron: ROA/SAP informatiesysteem UM

Tabel 6.9 geeft een overzicht van de mate waarin functies voor de wetenschappelijke staf in de jaren 1999-2004 intern zijn opgevuld. UD posities blijken relatief weinig intern te worden ingevuld, al is er de laatste jaren duidelijk sprake van een toename van de doorstroom van eigen promovendi naar UD functies. UHD functies worden daarentegen veel vaker intern ingevuld. De UHD functie fungeert hierdoor duidelijk als een interne carrièrestap voor het wetenschappelijk personeel. Bij het benoemen van hoogleraren wordt echter weer meer extern geworven, al neemt dit de laatste jaren sterk af.

Tabel 6.Io laat de verschillen op dit punt tussen de diverse faculteiten zien. Bij het aantrekken van UD is er een opmerkelijke tweedeling tussen aan de ene kant de facul-

I8. E. Lazear \& Sherwin Rosen (1981), "Rank-Order Tournaments as Optimum Labor Contracts", Journal of Political Economy, 89, pp. 84I-864. 
teiten Algemene Wetenschappen, Economie en Bedrijfskunde, Rechten en Gezondheidswetenschappen, die (bijna) de helft van de UD vacatures intern opvullen, en aan de andere kant de faculteiten Psychologie, Cultuurwetenschappen en Geneeskunde, die voor UD posities vrijwel altijd extern personeel aantrekken. In de meeste faculteiten worden vacatures voor UHD's voor het overgrote deel intern ingevuld. Alleen bij de relatief jonge faculteit Psychologie wordt slechts de helft van de UHD posities via interne promotie ingevuld. De faculteiten Psychologie en Rechten zijn de faculteiten waar hoogleraarposities met name extern worden ingevuld.

Tabel 6.10

Mate waarin UD, UHD en hoogleraarposities in de periode 1999-2004 intern zijn ingevuld, naar faculteit

$\begin{array}{lcccccccc} & \text { FdAW } & \text { FdCW } & \text { FdEWB } & \text { FdG } & \text { FdGW } & \text { FdP } & \text { FdR } & \text { UM } \\ & \% & \% & \% & \% & \% & \% & \% & \% \\ \text { UD } & 50 & 7 & 48 & 9 & 43 & 6 & 48 & 29 \\ \text { UHD } & 100 & 100 & 93 & 61 & 69 & 50 & 77 & 78 \\ \text { HGL } & 83 & 40 & 50 & 41 & 46 & 0 & 23 & 43 \\ \text { Bron: ROA/SAP informatiesysteem UM } & & & \end{array}$

Bron: ROA/SAP informatiesysteem UM

\subsection{Samenvatting: indicatoren voor de HRM portfolio}

In dit hoofdstuk is een overzicht gegeven van de instroom, uitstroom en interne doorstroom van het UM personeel. Van de gepresenteerde cijfers zou een aantal indicatoren kunnen worden opgenomen in de HRM portfolio. De geconstrueerde indicator van de 'omloopsnelheid' van het personeel geeft, zoals gezegd, een goed beeld van de mate waarin er sprake is van verversing van het personeel. Uit deze indicator blijkt dat de omloopsnelheid van het WP veel groter is dan de omloopsnelheid van het OBP. Ook blijkt dat de omloopsnelheid van het UM personeel de afgelopen jaren duidelijk is afgenomen. Het is vooralsnog niet duidelijk of dit het gevolg is van de conjuncturele ontwikkeling, of dat hier sprake is van een meer structurele trend.

Het zou ook interessant zijn om in de HRM portfolio een indicator op te nemen met betrekking tot de 'bestemming' van de personeelsuitstroom, verbijzonderd naar pensionering, arbeidsongeschiktheid, gaan werken bij andere universiteit en gaan werken in andere sector. Zoals in hoofdstuk 3 reeds werd aangegeven, wordt deze informatie echter nog niet systematisch verzameld.

Andere indicatoren die zouden kunnen worden opgenomen in de HRM portfolio hebben betrekking op de interne arbeidsmarkt. In de eerste plaats is het belangrijk om een indicator te hebben van de mate waarin vacatures voor de wetenschappelijke staf intern of extern worden opgevuld. Daarbij is het zinvol om een onderscheid te maken naar de verschillende functieniveaus: UD, UHD en hoogleraar. Uit deze indicator 
blijkt dat met name UD functies extern worden ingevuld, terwijl UHD functies voor het overgrote deel intern worden ingevuld. Deze functie fungeert hierdoor duidelijk als een interne carrièrestap voor het WP. Bij het benoemen van hoogleraren wordt echter weer meer extern geworven, al neemt dit de laatste jaren sterk af.

Voor het OBP is het percentage OBP'ers dat in vijf jaar tijd minstens één salarisschaal is gestegen een goede samenvattende indicator voor de verticale mobiliteit. Uit deze indicator blijkt dat bijna de helft van het OBP in de jaren 1999-2004 een dergelijke promotie heeft gehad. Daarbij is er wel een duidelijk verschil tussen het OBP dat werkzaam bij de ondersteunende diensten (64\% opwaarts mobiel) en het meestal secretariële personeel dat werkzaam is (gebleven) binnen de capaciteitsgroepen $(39 \%$ opwaarts mobiel).

Ten slotte zou er in de HRM portfolio een indicator kunnen worden opgenomen van de mobiliteit van het OBP tussen de verschillende faculteiten, het bureau van de universiteit en de servicecentra. Deze indicator betreft het percentage OBP'ers dat in vijf jaar tijd bij een andere organisatie van de UM is gaan werken. Uit deze indicator blijkt dat OBP'ers die werkzaam zijn bij de faculteiten Economie en Psychologie de hoogste mobiliteit naar andere organisaties binnen de UM hebben. Deze indicator wordt echter wel vervuild door de 'schijnmobiliteit' als gevolg van het verplaatsen van afdelingen of functies van de ene naar de andere organisatie binnen de UM. 


\section{HRM beleid}

Het tweede terrein waarin deze HRM portfolio inzicht wil geven is het binnen de Universiteit Maastricht gevoerde HRM beleid. De beherend bazen van de capaciteitsgroepen en de ondersteunende diensten staat immers een groot aantal instrumenten ter beschikking om hun personeelsbeleid optimaal in te richten. Informatie over het gebruik van deze HRM instrumenten wordt echter niet structureel verzameld, laat staan dat hiervan op centraal niveau een overzicht is (zie ook hoofdstuk 3). Om toch uitspraken te kunnen doen over het gevoerde HRM beleid binnen de UM, hebben we in de enquête onder beherend bazen ${ }^{19}$ een aantal vragen over dit onderwerp gesteld. We zullen in dit hoofdstuk achtereenvolgens ingaan op de volgende vier facetten van het gevoerde HRM beleid:

- werving en selectie;

- arbeidsvoorwaardenbeleid;

- personeelsontwikkelingsbeleid;

- scholing van medewerkers.

Ook zullen we aandacht besteden aan de belemmeringen bij het personeelsbeleid, zoals die door de beherend bazen van de capaciteitsgroepen en de ondersteunende diensten ervaren worden. We sluiten dit hoofdstuk af met een overzicht van de belangrijkste indicatoren op het gebied van het gevoerde HRM beleid. Deze indicatoren kunnen deel uit gaan maken van de HRM portfolio UM.

We beginnen dit hoofdstuk echter met informatie over de beherend bazen zelf. Opgemerkt moet worden dat het aantal beherend bazen dat de enquête heeft ingevuld, met name bij de capaciteitsgroepen, niet groot is. In totaal hebben 25 van de 69 beherend bazen van de capaciteitsgroepen en 32 van de 44 beherend bazen (en enkele werkbazen) van de ondersteunende diensten de vragenlijsten ingevuld (zie tabel 4.I). Door de vrij lage respons dienen de in dit hoofdstuk gepresenteerde resultaten met enige voorzichtigheid geïnterpreteerd te worden.

19. Meer informatie over de enquête onder beherend bazen is te vinden in hoofdstuk 4 . 


\subsection{Beherend bazen van capaciteitsgroepen en ondersteunende diensten}

Voordat we nader ingaan op het in de capaciteitsgroepen en de ondersteunende diensten gevoerde HRM beleid, willen we eerst een beeld schetsen van degenen die leiding geven aan de verschillende organisatie-eenheden. Tabel 7.I geeft een overzicht van de leeftijd en de werkervaring van de ondervraagde beherend bazen. Hun leeftijd loopt uiteen van 37 tot 62 jaar, maar zowel bij de capaciteitsgroepen als bij de ondersteunende diensten zijn de beherend bazen gemiddeld 50 jaar oud. Ze zijn gemiddeld zo'n 6 jaar werkzaam als beherend baas van hun capaciteitsgroep of dienst, al verschilt dit zeer per organisatie-eenheid. Zo zijn er beherend bazen die minder dan een jaar in hun huidige functie werkzaam zijn, maar ook die al meer dan I8 jaar op hun plek zitten. De tabel laat ten slotte ook zien dat de beherend bazen gemiddeld genomen zo'n I3 à I4 jaar ervaring hebben met het leidinggeven aan personeel. Ook hier zijn weer grote verschillen te vinden en loopt de ervaring uiteen van o tot 33 jaar.

Tabel 7.1

Kenmerken van beherend bazen

$\begin{array}{lcc} & \begin{array}{c}\text { Capaciteitsgroepen } \\ \text { Gemiddelde }\end{array} & \begin{array}{c}\text { Ondersteunende } \\ \text { diensten } \\ \text { Gemiddelde }\end{array} \\ \text { Leeftijd (in jaren) } & 50,6 & 49,2 \\ \text { Aantal jaren beherend baas van huidige organisatie-eenheid } & 6,2 & 6,0 \\ \text { Aantal jaren in leidinggevende functie } & 12,8^{*} & 14,4 \\ & & \\ \text { * Het betreft hier het leidinggeven aan WP'ers } & & \\ \text { Bron: ROA/Enquête onder beherend bazen 2005 } & \end{array}$

Om na te gaan hoe de beherend bazen hun eigen leidinggevende kwaliteiten waarderen, hebben we hen enkele vragen over hun managementstijl voorgelegd. Deze vragen zijn een selectie uit een langere reeks vragen uit de Krauthammer vragenlijst, die de beherend bazen tijdens de cursussen "UM leiderschap" voorgelegd hebben gekregen, en die bedoeld zijn om een beeld te verkrijgen van de eigen kwaliteiten op een aantal terreinen in vergelijking met collega's in vergelijkbare posities.

Tabel 7.2 geeft aan dat de beherend bazen over het algemeen vinden dat ze het beter doen dan hun collega's ${ }^{20}$, vooral wanneer het gaat om het beschikbaar zijn en luisteren naar anderen en het stimuleren van medewerkers en collega's om zich beroepsmatig te ontwikkelen. Minder goed scoren ze op het nee kunnen zeggen wanneer dat nodig is. De beherend bazen van de capaciteitsgroepen geven zichzelf ook een relatief lage score voor het uiten van waardering voor successen en inspanningen. De tabel maakt duidelijk dat de beherend bazen van de ondersteunende diensten zichzelf betere leidinggevende kwaliteiten toedichten wanneer ze zich vergelijken met collega's dan de beherend bazen van de capaciteitsgroepen. Dit wijst er op dat de beherend bazen

20. Een score van 3 geeft aan dat men zichzelf evenveel kwaliteiten toedicht als collega's in een vergelijkbare positie. 
van de ondersteunende diensten een sterkere focus op hun leidinggevende rol hebben dan de beherend bazen van de capaciteitsgroepen.

\section{Tabel 7.2}

Managementstijl van beherend bazen; zelfrapportage op een schaal van 1 (veel slechter) tot en met 5 (veel beter) in vergelijking met collega's in vergelijkbare posities

$\begin{array}{lcc} & \begin{array}{c}\text { Capaciteits- } \\ \text { groepen } \\ \text { Gemiddelde }\end{array} & \begin{array}{c}\text { Ondersteunende } \\ \text { diensten } \\ \text { Gemiddelde }\end{array} \\ \text { Ik ben beschikbaar en luister naar anderen } & 4,0 & 3,9 \\ \text { Ik stimuleer mijn medewerkers en collega's zich beroepsmatig te ontwikkelen } & 3,7 & 4,0 \\ \text { Ik bereid me voor op vergaderingen en gesprekken } & 3,7 & 3,6 \\ \text { Ik creëer draagvlak voor mijn beslissingen } & 3,6 & 3,8 \\ \text { In onderhandelingen streef ik naar " win-win" overeenkomsten } & 3,6 & 3,7 \\ \text { Ik draag visie en strategie op een consistente wijze uit } & 3,5 & 3,8 \\ \text { Ik uit waardering voor successen en inspanningen } & 3,4 & 3,8 \\ \text { Ik kan nee zeggen } & 2,8 & 3,2 \\ \text { Bron: ROA/Enquête onder beherend bazen 2005 } & & \end{array}$

Bron: ROA/Enquête onder beherend bazen 2005

Aan de beherend bazen van de capaciteitsgroepen is ook een aantal vragen voorgelegd over de mate waarin ze gericht zijn op het versterken van de onderzoeks- en onderwijsreputatie van hun groep. Tabel 7.3 laat zien dat de capgroepvoorzitters gemiddeld genomen vinden dat ze hier meer aandacht aan besteden dan collega's in vergelijkbare posities. Ook stimuleren zij discussies over het onderzoek. Opvallend is dat de scores voor het versterken van de onderzoeksreputatie even hoog zijn als de scores voor het versterken van de onderwijsreputatie. Later in dit hoofdstuk zullen we immers zien dat de beherend bazen van de capaciteitsgroepen de voorkeur geven aan onderzoek boven onderwijs.

\section{Tabel 7.3}

Managementstijl van beherend bazen van de capaciteitsgroepen; zelfrapportage op een schaal van 1 (veel minder) tot en met 5 (veel meer) in vergelijking met collega's in vergelijkbare posities

$\begin{array}{lc} & \begin{array}{c}\text { Capaciteits- } \\ \text { groepen } \\ \text { Gemiddelde }\end{array} \\ \text { Ik stimuleer discussies over het onderzoek } & 3,5 \\ \text { Ik ben gericht op het versterken van de onderzoeksreputatie van mijn capgroep } & 3,5 \\ \text { Ik ben gericht op het verstreken van de onderwijsreputatie van mijn capgroep } & 3,5 \\ \text { Bron: ROA/Enquête onder beherend bazen } 2005 & \end{array}$

\subsection{Werving en selectie}

Een eerste facet van het HRM beleid wordt gevormd door het wervings- en selectiebeleid. Aan de beherend bazen van de capaciteitsgroepen is gevraagd hoe ze de functies van universitair docenten (UD's), uitgaande van de huidige personeelssa- 
menstelling van hun groep, graag zouden willen invullen. Tabel 7.4 geeft een overzicht van de antwoorden. De beherend bazen zien UD's het liefst de meeste tijd aan onderzoek besteden. Gemiddeld genomen zouden ze minimaal $36 \%$ en maximaal $64 \%$ van hun werktijd onderzoek moeten doen. Deze percentages lopen overigens uiteen van o tot $75 \%$ (minimale tijd) tot 35 tot Ioo\% (maximale tijd). Opvallend hierbij is dat bijna alle beherend bazen het maximum percentage boven de standaard binnen hun faculteit leggen. In de FdEWB geldt bijvoorbeeld een standaardverdeling tussen onderwijs, onderzoek en bestuurlijke taken van 50-40-IO, terwijl de beherend bazen van deze faculteit de gewenste maximale tijd voor onderzoek gemiddeld genomen bij bijna $70 \%$ leggen. Wat het onderwijs betreft, is de maximale tijd juist gelijk aan de afgesproken standaard. De beherend bazen zien voor onderwijs idealiter gemiddeld genomen $26 \%$ (minimaal) tot $53 \%$ (maximaal) van de werktijd van UD's ingeruimd. Ook hier variëren de percentages sterk tussen de verschillende capaciteitsgroepen. Bestuurlijke taken ten slotte zouden gemiddeld 3\% (minimaal) tot I6\% (maximaal) van de werktijd van UD's moeten innemen.

Tabel 7.4

Gewenste invulling van de functie voor universitair docent binnen capaciteitsgroepen

\begin{tabular}{lcccc} 
& \multicolumn{2}{c}{ Minimaal } & \multicolumn{2}{c}{ Maximaal } \\
& $\begin{array}{c}\text { Gemiddelde } \\
\%\end{array}$ & $\begin{array}{c}\text { Range } \\
\text { Gemiddelde }\end{array}$ & $\begin{array}{c}\text { Range } \\
\%\end{array}$ \\
Onderwijstaken & 26 & $0-50$ & 53 & $15-90$ \\
Onderzoekstaken & 36 & $0-75$ & 64 & $35-100$ \\
Bestuurlijke taken & 3 & $0-20$ & 16 & $0-40$ \\
Bron: ROA/Enquête onder beherend bazen 2005 & & & &
\end{tabular}

De voorkeur voor onderzoek boven onderwijs blijkt ook uit de afwegingen die gemaakt worden bij de selectie van nieuw personeel. Bij een vacature voor een UD krijgen kandidaten met onderzoekskwaliteiten namelijk over het algemeen de voorkeur boven kandidaten met onderwijskwaliteiten. Dit blijkt wanneer de beherend bazen keuzes voorgelegd krijgen met fictieve kandidaten die verschillen in onderzoeks- en onderwijskwaliteiten. ${ }^{21} \mathrm{Op}$ basis van de antwoorden zijn twee indexen te construeren die duidelijk de voorkeur van beherend bazen voor medewerkers met goede onderzoekskwaliteiten weergeven. Gemeten op een schaal van I tot 6 hebben beherend bazen een voorkeur van gemiddeld 4,o voor een UD met onderzoekskwaliteiten en een voorkeur van 2,5 voor een UD met onderwijskwaliteiten. Ten opzichte van een kandidaat met gemiddelde onderzoeks- en onderwijskwaliteiten wordt dus eerder iemand met bovengemiddelde onderzoekskwaliteiten aangenomen dan iemand met bovengemiddelde onderwijskwaliteiten. Sterker gezegd, $68 \%$ van de beherend bazen verkiest een kandidaat met bovengemiddelde onderzoekskwaliteiten en matige onderwijskwaliteiten boven een kandidaat met gemiddelde kwaliteiten, terwijl omge-

2I. Het gaat om een reeks van keuzes tussen kandidaten met slechte, matige, bovengemiddelde en uitmuntende onderzoeks- of onderwijskwaliteiten, versus kandidaten met gemiddelde onderzoeks- of onderwijskwaliteiten, die op andere punten geheel gelijkwaardig zijn. 
keerd slechts $36 \%$ een kandidaat met bovengemiddelde onderwijskwaliteiten en matige onderzoekskwaliteiten verkiest.

Vergelijkbare vragen zijn aan de beherend bazen van de ondersteunende diensten gesteld. Gevraagd is naar hun voorkeur voor vakspecifieke kwaliteiten en communicatieve kwaliteiten bij een vacature voor een functie die belangrijk is voor de kwaliteit van de dienstverlening. De beherend bazen van de ondersteunende diensten laten een veel minder duidelijke voorkeur zien, maar kiezen over het algemeen wel voor personeel met vakspecifieke kwaliteiten boven communicatieve kwaliteiten. Hun voorkeur voor vakspecifieke kwaliteiten is gemiddeld 2,I tegenover een voorkeur van I,5 voor communicatieve kwaliteiten (beide gemeten op een schaal van I tot 6).

\section{Moeilijk vervulbare vacatures}

Vier van de tien beherend bazen van de capaciteitsgroepen geven aan dat er de afgelopen twee jaar moeilijk vervulbare vacatures voor wetenschappelijk personeel zijn geweest. Dit werd met name veroorzaakt door een gebrek aan geschikte kandidaten. Slechts iets meer dan de helft van de beherend bazen geeft aan dat er bepaalde aanpassingen hebben plaatsgevonden om deze moeilijk vervulbare vacatures voor wetenschappelijk personeel ingevuld te krijgen. Gezien de aard van de moeilijk vervulbare vacatures is het niet vreemd dat men er vooral toe overging om mogelijk geschikte kandidaten actiever persoonlijk te benaderen of een collegiaal netwerk inschakelde. In geen enkele capaciteitsgroep zijn er om een moeilijk vervulbare vacature ingevuld te krijgen betere arbeidsvoorwaarden geboden, zoals een hoger salaris of arbeidsmarkttoeslagen, betere secundaire arbeidsvoorwaarden, meer tijd voor onderzoek of meer faciliteiten als een reisbudget e.d.

In eveneens $40 \%$ van de ondersteunende diensten hebben zich de afgelopen twee jaar moeilijk vervulbare vacatures voorgedaan. De beherend bazen noemen ook hier het gebrek aan geschikte kandidaten als de belangrijkste reden, maar geven even vaak aan dat er gewoon geen sollicitanten waren, of dat er wel een goede kandidaat was, maar dat het aanbod dat zij deze kandidaat deden niet concurrerend genoeg was. In tegenstelling tot de capaciteitsgroepen, heeft de overgrote meerderheid van de beherend bazen van de ondersteunende diensten maatregelen genomen om moeilijk vervulbare vacatures ingevuld te krijgen. Ook hier ging men vooral mogelijk geschikte kandidaten actiever persoonlijk benaderen. Daarnaast wordt het afzwakken van de functieeisen, het bieden van een hoger salaris of arbeidsmarkttoelagen en betere secundaire arbeidsvoorwaarden genoemd. Ook werd in sommige gevallen een commercieel wervingsbureau ingeschakeld. 


\subsection{Arbeidsvoorwaardenbeleid voor medewerkers}

Het HRM beleid aan de UM wordt ook gevormd door het arbeidsvoorwaardenbeleid. In de CAO Nederlandse Universiteiten zijn alle salarisschalen vastgelegd. Een medewerker wordt afhankelijk van het niveau van de functie en zijn of haar kennis en ervaring in deze schalen ingepast.

Aanvullend kan een arbeidsmarkttoelage worden toegekend. Deze toelages worden verstrekt om redenen van werving en behoud en kunnen bestaan uit een maandelijkse toelage bovenop het salaris (koop- of behoudtoelage) of uit een bedrag ineens na een bepaalde tijd (bindingspremie). Uit het SAP informatiesysteem valt op te maken dat een arbeidsmarkttoelage momenteel slechts zeer sporadisch verstrekt wordt. Bij de Faculteit der Geneeskunde komen arbeidsmarkttoelagen wat vaker voor, maar ook hier betreft het slechts enkele medewerkers. In het verleden werden deze toelagen veel vaker verstrekt, met name om promovendi te compenseren voor hun relatief lage salaris.

Ook kan er incidenteel een gratificatie worden toegekend. Een dergelijke gratificatie is met name bedoeld als beloning voor uitzonderlijke prestaties en kwaliteiten. Gegevens verkregen uit het SAP informatiesysteem laten zien dat bijna een kwart van de medewerkers in 2005 een gratificatie heeft gekregen. Daarbij is er een opmerkelijk verschil tussen de medewerkers in de capaciteitsgroepen - $17 \%$ kreeg een gratificatie - en de medewerkers in de ondersteunende diensten, waarvan $31 \%$ een gratificatie ontving. ${ }^{22}$ OBP'ers krijgen ook vaker een gratificatie dan WP'ers.

Naast het arbeidsvoorwaardenbeleid, zijn secundaire arbeidsvoorwaarden van belang. De mate waarin medewerkers gebruik maken van aangeboden faciliteiten geeft derhalve ook een indicatie van het gevoerde HRM beleid. Het gaat dan om zaken als reiskostenvergoedingen, spaarloonregeling, tegemoetkoming in de kinderopvang, ouderschapsverlof en de seniorenregeling, waarbij werknemers ouder dan 59 jaar onder bepaalde voorwaarden hun werktijd kunnen verminderen.

Per I januari 2005 is bovendien het Keuzemodel Arbeidsvoorwaarden UM ingegaan, waarbij werknemers de mogelijkheid hebben om arbeidsvoorwaarden tegen elkaar uit te wisselen en zo hun arbeidsvoorwaarden aan te passen aan eigen wensen en privéomstandigheden. In dit keuzemodel kunnen bronnen in tijd (bijvoorbeeld vakantiedagen) of geld (bijvoorbeeld een deel van het loon) uitgewisseld worden tegen doelen, die ook weer in tijd (zoals vakantiedagen, flexibele werkduur, sabbatical leave, verlenging van ouderschapsverlof en studieverlof) of geld (extra opbouw FPU, fiets in het kader van de fietsregeling UM, salaris, vakbondscontributie en contributie van een vakvereniging) uitgedrukt worden.

22. Het percentage medewerkers dat een gratificatie heeft ontvangen liggen vrij hoog omdat enkele faculteiten of organisatie-eenheden geen individuele maar collectieve gratificaties hebben uitgekeerd. 
Op dit moment wordt niet centraal bijgehouden hoe populair deze secundaire arbeidsvoorwaarden bij het personeel zijn. We kunnen hierover dan ook geen gegevens in deze HRM portfolio presenteren. Het is immers weinig zinvol om dergelijke informatie via een enquête onder de beherend bazen boven tafel te krijgen, omdat zij veelal niet op de hoogte zijn van de individuele keuzes van medewerkers.

\subsection{Personeelsontwikkelingsbeleid}

In de enquête is ook gevraagd of men het belangrijk vindt om de ontwikkeling van het personeel te stimuleren. Nagenoeg alle beherend bazen van de capaciteitsgroepen vinden dit altijd belangrijk; slechts één beherend baas antwoordt dat de ontwikkeling van het personeel belangrijk is, maar alleen wanneer er op dit punt problemen zijn. De beherend bazen van de ondersteunende diensten vinden de ontwikkeling van het personeel allemaal belangrijk, maar alleen wanneer er op dit punt problemen zijn.

Tabel 7.5

Belang van HRM instrumenten voor de ontwikkeling van medewerkers

$\begin{array}{lcc} & \begin{array}{c}\text { Capaciteits- } \\ \text { groepen* }\end{array} & \begin{array}{c}\text { Ondersteunende } \\ \text { diensten }\end{array} \\ & \% & \% \\ \text { Functioneringsgesprekken } & 84 & 94 \\ \text { Beoordelingsgesprekken } & 52 & 75 \\ \text { Coaching van individuele werknemers } & 64 & 81 \\ \text { Persoonlijke ontwikkelingsplannen (POPs) } & 40 & 63 \\ \text { Bij- en nascholing } & 52 & 75 \\ \text { Prestatiebeloning op individueel niveau } & 44 & 44 \\ \text { Prestatiebeloning op teamniveau } & 4 & 16 \\ \text { Anders } & 20 & 14 \\ \text { * Het betreft hier de ontwikkeling van WP'ers } & & \\ \text { Bron: ROA/Enquête onder beherend bazen 2005 } & & \end{array}$

Daarnaast is gevraagd welke HRM instrumenten men belangrijk vindt voor de ontwikkeling van het personeel waaraan men leiding geeft. Tabel 7.5 laat zien dat beherend bazen met name het voeren van functioneringsgesprekken belangrijk vinden. $84 \%$ van de beherend bazen van de capaciteitsgroepen vindt deze gesprekken belangrijk voor de ontwikkeling van hun wetenschappelijk personeel, terwijl maar liefst $94 \%$ van de beherend bazen van de ondersteunende diensten functioneringsgesprekken belangrijk vindt voor de ontwikkeling van hun personeel. Ook de coaching van individuele werknemers, beoordelingsgesprekken en bij- en nascholing worden belangrijk gevonden. Opvallend is dat de beherend bazen van de ondersteunende diensten al deze HRM instrumenten vaker belangrijk vinden voor de ontwikkeling van hun personeel dan de beherend bazen van capaciteitsgroepen. Bovendien vinden zij vaker de persoonlijk ontwikkelingsplannen (POPs) belangrijk voor hun medewerkers: 63\% tegenover $40 \%$ van de beherend bazen van de capaciteitsgroepen. Prestatiebeloning, en met name prestatiebeloning op teamniveau, wordt minder van belang geacht 
voor de personeelsontwikkeling. Wel wordt prestatiebeloning op teamniveau door de beherend bazen van de ondersteunende diensten wat vaker belangrijk gevonden dan door de capgroepvoorzitters. Dit laatste heeft waarschijnlijk te maken met het feit dat er binnen de ondersteunende diensten vaker in een team gewerkt wordt dan binnen de capaciteitsgroepen, terwijl men wetenschappelijk personeel toch vooral op individuele prestaties wil afrekenen.

Eén op de vijf beherend bazen van de capaciteitsgroepen noemt een ander instrument dat volgens hen van belang is voor de ontwikkeling van WP'ers, zoals een sabbatical leave en het stimuleren van een tijdelijk verblijf aan een buitenlandse universiteit. De beherend bazen van de ondersteunende diensten noemen de samenwerking met andere instituten en geregeld werkoverleg waarin ook het welbevinden van medewerkers wordt besproken. In dit opzicht zou het dus interessant zijn om gegevens te verzamelen over de uitwisseling van medewerkers met andere wetenschappelijke instituten en ondersteunende diensten, zowel binnen als buiten de UM, en het verblijf van medewerkers in het buitenland, bijvoorbeeld tijdens een sabbatical leave.

\section{Inzet van HRM instrumenten door beherend bazen}

Het is de vraag in hoeverre de door de beherend bazen belangrijk gevonden HRM instrumenten ook daadwerkelijk worden ingezet. Tabel 7.6 geeft aan dat alle beherend bazen van de capaciteitsgroepen functionerings- en beoordelingsgesprekken met hun wetenschappelijk personeel voeren. Functioneringsgesprekken worden in $84 \%$ van de capaciteitsgroepen met alle WP'ers gehouden. Slechts $4 \%$ van de beherend bazen voert maar met enkele medewerkers functioneringsgesprekken. Beoordelingsgesprekken komen wat minder vaak voor. $74 \%$ van de beherend bazen geeft aan met alle WP'ers beoordelingsgesprekken te voeren, terwijl 22\% dit slecht met enkele WP'ers doet.

\section{Tabel 7.6}

Inzet van HRM instrumenten voor het WP bij de capaciteitsgroepen

$\begin{array}{lcccc} & \begin{array}{c}\text { Voor alle } \\ \text { WP'ers }\end{array} & \begin{array}{c}\text { Voor de } \\ \text { meeste } \\ \text { WP'ers }\end{array} & \begin{array}{c}\text { Voor enkele } \\ \text { WP'ers }\end{array} & \text { Niet } \\ \text { Functioneringsgesprekken } & \% & \% & \% & \% \\ \text { Beoordelingsgesprekken } & 84 & 12 & 4 & 0 \\ \text { Coaching van individuele werknemers } & 74 & 4 & 22 & 0 \\ \text { Persoonlijke ontwikkelingsplannen (POPs) } & 13 & 22 & 52 & 13 \\ \text { Bij- en nascholing } & 15 & 10 & 35 & 40 \\ \text { Prestatiebeloning op individueel niveau } & 22 & 17 & 30 & 30 \\ \text { Prestatiebeloning op teamniveau } & 0 & 0 & 45 & 55 \\ \text { Bron: ROA/Enquête onder beherend bazen 2005 } & 6 & 0 & 6 & 89\end{array}$

De overige HRM instrumenten worden (lang) niet in alle capaciteitsgroepen ingezet. Coaching van individuele medewerkers is wel redelijk populair, maar in de meeste capgroepen wordt dit slechts bij enkele WP'ers toegepast (52\%). Dit is vrij opmer- 
kelijk, aangezien $64 \%$ van de beherend bazen coaching van individuele medewerkers belangrijk vindt voor de ontwikkeling van hun personeel. Persoonlijke ontwikkelingsplannen (POPs) komen in 60\% van de capaciteitsgroepen voor, maar ook deze worden meestal slechts voor enkele WP'ers opgesteld. Bij- en nascholing wordt daarentegen wel vaker door alle (22\%) of de meeste WP'ers (I7\%) gevolgd. Ten slotte laat de tabel zien dat prestatiebeloning slechts bij een minderheid van de capaciteitsgroepen wordt ingezet, zeker wanneer het om prestatiebeloning op teamniveau gaat (II\%). Zoals uit tabel 7.5 bleek, vinden de beherend bazen dit instrument ook het minst belangrijk voor de ontwikkeling van hun personeel. In $45 \%$ van de capaciteitsgroepen wordt prestatiebeloning op individueel niveau toegepast. Dit heeft in alle gevallen slechts betrekking op enkele WP'ers. Andere instrumenten, die de beherend bazen van de capaciteitsgroepen noemen wanneer er gevraagd wordt naar hun HRM beleid voor WP'ers zijn gratificaties, het creëren van tijdelijke (extra) onderzoeksruimte en het faciliteren en stimuleren van een buitenlands verblijf.

Uit tabel 7.7 blijkt dat de beherend bazen van de ondersteunende diensten over het algemeen meer gebruik maken van HRM instrumenten dan de beherend bazen van de capaciteitsgroepen. Dit weerspiegelt de sterkere focus op hun leidinggevende rol. Zo vinden in $94 \%$ van de ondersteunende diensten functioneringsgesprekken met alle medewerkers plaats, en in $87 \%$ beoordelingsgesprekken. Ook coaching van individuele medewerkers en persoonlijke ontwikkelingsplannen komen in de meerderheid van de ondersteunende diensten voor, al gaat het daarbij veelal slechts om enkele medewerkers. Alle beherend bazen geven daarnaast aan dat hun medewerkers bij- en nascholing volgen. In ruim de helft van de gevallen geldt dit voor de meeste of zelfs alle medewerkers. Ten slotte vindt er bij de ondersteunende diensten ook vaker prestatiebeloning plaats dan bij de capaciteitsgroepen. Evenals bij de capaciteitsgroepen is er daarbij veel vaker sprake van prestatiebeloning op individueel niveau dan van prestatiebeloning op teamniveau. Andere instrumenten die de beherend bazen van de ondersteunende diensten bij hun HRM beleid inzetten zijn bijvoorbeeld op maat gemaakte afspraken over loopbaanontwikkeling.

\section{Tabel 7.7}

Inzet van HRM instrumenten voor medewerkers bij de ondersteunende diensten

$\begin{array}{lcccc} & \begin{array}{c}\text { Voor alle } \\ \text { medewerkers } \\ \%\end{array} & \begin{array}{c}\text { Voor de meeste } \\ \text { medewerkers } \\ \%\end{array} & \begin{array}{c}\text { Voor enkele } \\ \text { medewerkers } \\ \%\end{array} & \text { Niet } \\ \text { Functioneringsgesprekken } & 94 & 3 & 3 & 0 \\ \text { Beoordelingsgesprekken } & 87 & 7 & 7 & 0 \\ \text { Coaching van individuele werknemers } & 16 & 13 & 61 & 10 \\ \text { Persoonlijke ontwikkelingsplannen (POPS) } & 28 & 0 & 43 & 29 \\ \text { Bij- en nascholing } & 20 & 37 & 43 & 0 \\ \text { Prestatiebeloning op individueel niveau } & 13 & 4 & 35 & 48 \\ \text { Prestatiebeloning op teamniveau } & 10 & 5 & 5 & 80\end{array}$


Zoals gezegd zijn functioneringsgesprekken het meest populaire HRM instrument, zowel voor wat betreft het belang voor de ontwikkeling van het personeel, als het daadwerkelijke gebruik van dit instrument. Tabel 7.8 laat zien dat in $76 \%$ van de capaciteitsgroepen jaarlijks (of vaker) functioneringsgesprekken gevoerd worden. Bij de ondersteunende diensten ligt dit percentage nog hoger: bij $88 \%$ van de diensten worden minstens jaarlijks functioneringsgesprekken gevoerd. De overige groepen of diensten hebben tweejaarlijkse functioneringsgesprekken.

Tabel 7.8

Frequentie van de functioneringsgesprekken

$\begin{array}{lccc} & \text { Jaarlijks (of vaker) } & \text { Tweejaarlijks } & \text { Minder } \\ & \% & \% & \% \\ \text { Capaciteitsgroepen } & 76 & 24 & 0 \\ \text { Ondersteunende diensten } & 88 & 13 & 0 \\ \text { Bron: ROA/Enquête onder beherend bazen } 2005 & & & \end{array}$

$84 \%$ van de beherend bazen van de capaciteitsgroepen makt altijd een schriftelijk verslag van de functioneringsgesprekken, de rest doet dit meestal (zie tabel 7.9). Bij de ondersteunende diensten liggen deze percentages opnieuw hoger. Hier wordt door 9I\% van de beherend bazen altijd een functioneringsgesprekverslag gemaakt.

Tabel 7.9

Schriftelijk verslag van de functioneringsgesprekken

$\begin{array}{lcccc} & \text { Ja, altijd } & \text { Meestal } & \text { Soms } & \text { Nooit } \\ & \% & \% & \% & \% \\ \text { Capaciteitsgroepen } & 84 & 16 & 0 & 0 \\ \text { Ondersteunende diensten } & 91 & 9 & 0 & 0 \\ \text { Bron: ROA/Enquête onder beherend bazen 2005 } & & & \end{array}$

Uit het bovenstaande kunnen we concluderen dat de beherend bazen van de ondersteunende diensten meer gebruik maken van de standaard HRM instrumenten dan de beherend bazen van de capaciteitsgroepen. Waarschijnlijk heeft dit te maken met de meer op hun managementrol gerichte oriëntatie van de beherend bazen bij de ondersteunende diensten. Beherend bazen van de capaciteitsgroepen daarentegen zijn doorgaans hoogleraren die op grond van hun onderzoeks- en onderwijsprestaties manager zijn geworden. Zij hebben wellicht meer oog voor het direct faciliteren van onderzoek en onderwijs dan voor het inzetten van de standaard HRM instrumenten. In de enquête is dan ook aan de beherend bazen van de capaciteitsgroepen gevraagd in hoeverre het wetenschappelijk personeel deelneemt aan wetenschappelijke congressen, interne seminars en internationale uitwisseling. Voor de ontwikkeling van WP'ers zijn dit immers de HRM instrumenten pur sang.

Tabel 7.IO laat zien dat in $56 \%$ van de capaciteitsgroepen deelname aan wetenschappelijke congressen als instrument voor alle WP'ers wordt ingezet, terwijl dit in 
de overige capgroepen voor de meeste WP'ers geldt. Presentaties op interne seminars wordt iets minder vaak ingezet: in $\mathrm{I} 3 \%$ van de capaciteitsgroepen zelfs helemaal niet. Ook internationale uitwisseling wordt vaak gestimuleerd, al geldt dit bij eenderde van de capaciteitsgroepen slechts voor enkele WP'ers.

Tabel 7.10

Inzet van instrumenten als deelname aan congressen, seminars en internationale uitwisseling voor het WP bij de capaciteitsgroepen

$\begin{array}{lcccc} & \begin{array}{c}\text { Voor alle } \\ \text { WP'ers }\end{array} & \begin{array}{c}\text { Voor de } \\ \text { meeste } \\ \text { WP'ers }\end{array} & \begin{array}{c}\text { Voor enkele } \\ \text { WP'ers }\end{array} & \text { Niet } \\ & \% & \% & \% & \% \\ \text { Deelname aan wetenschappelijke congressen } & 56 & 44 & 0 & 0 \\ \text { Presentaties op interne seminars } & 46 & 29 & 13 & 13 \\ \text { Stimuleren van internationale uitwisseling } & 32 & 20 & 32 & 8 \\ \text { Bron: ROA/Enquête onder beherend bazen } 2005 & & & \end{array}$

In 2004 heeft overigens, gemiddeld genomen, $53 \%$ van het wetenschappelijk personeel een of meerdere papers op een international congres gepresenteerd. Het is opmerkelijk dat dit percentage tussen de verschillende capaciteitsgroepen sterk varieert van I $4 \%$ tot $100 \%$ van de WP'ers in de capgroep. De beherend bazen vinden deelname aan wetenschappelijke congressen $(84 \%)$ en internationale uitwisseling $(72 \%)$ belangrijk voor de ontwikkeling van hun wetenschappelijk personeel. Aan het presenteren op interne seminars wordt over het algemeen beduidend minder waarde gehecht; $48 \%$ van de beherend bazen vindt dit belangrijk. Het is opvallend dat de beherend bazen van de FdG internationale uitwisseling over het algemeen wat minder belangrijk vinden dan de beherend bazen van andere faculteiten.

\section{Prestatiedoelen}

Het belang van het direct faciliteren van onderzoek en onderwijs binnen de capaciteitsgroepen blijkt ook uit het formuleren van prestatiedoelen. Alhoewel prestatiebeloning geen gemeengoed is binnen de UM, worden er wel vaak concrete prestatiedoelen geformuleerd. Tabel 7.II geeft aan dat deze doelen in vrijwel alle capaciteitsgroepen betrekking hebben op de onderzoeksprestaties, terwijl in $84 \%$ van de capgroepen prestatiedoelen met betrekking tot het onderwijs zijn geformuleerd. $32 \%$ van de beherend bazen van de capaciteitsgroepen noemt andere prestatiedoelen, zoals bestuurlijke taken en subsidieverwerving. Slechts $4 \%$ van de beherend bazen antwoordt dat er geen concrete prestatiedoelen binnen hun capaciteitsgroep bestaan.

Prestatiedoelen worden met name geformuleerd voor UHD's (92\%), UD's (83\%) en promovendi (75\%). Slechts bij 54\% van de capaciteitsgroepen zijn concrete prestatiedoelen voor hoogleraren opgesteld. I7\% van de beherend bazen van capaciteitsgroepen formuleert prestatiedoelen voor andere medewerkers zoals postdocs en OBP'ers. 
Tabel 7.11

Concrete prestatiedoelen voor het WP bij de capaciteitsgroepen

$\begin{array}{lr} & \% \\ \text { Onderzoek } & 96 \\ \text { Onderwijs } & 84 \\ \text { Anders } & 32 \\ \text { Geen } & 4 \\ \text { Bron: ROA/Enquête onder beherend bazen } 2005 & \end{array}$

Ook bij een meerderheid van de ondersteunende diensten worden specifieke prestatiedoelen voor individuele medewerkers geformuleerd. Dit is bij $62 \%$ van de ondersteunende diensten het geval. In de meeste gevallen gaat het om prestatiedoelen voor enkele medewerkers (38\%). Daarnaast geeft I3\% van de beherend bazen aan dat er voor alle medewerkers prestatiedoelen geformuleerd worden. Bij eveneens $13 \%$ van de ondersteunende diensten gebeurt dit voor de meeste medewerkers.

\subsection{Scholing van medewerkers}

Een ander belangrijk onderdeel van het HRM beleid is de scholing van medewerkers. Hierboven zagen we al dat veel beherend bazen grote waarde hechten aan de bij- en nascholing van hun personeel. Cijfers over de trainingsparticipatie van medewerkers worden echter niet structureel binnen de UM verzameld. Uit de enquête onder de beherend bazen van de capaciteitsgroepen blijkt dat in 2004 gemiddeld genomen $4 \mathrm{I} \%$ van de WP'ers minimaal één interne of externe cursus of training gevolgd heeft. Hetzelfde geldt voor het OBP in de ondersteunende diensten - ook hier heeft $4 \mathrm{I} \%$ aan cursussen deelgenomen. Het percentage varieert overigens sterk tussen de verschillende organisatie-eenheden en ligt tussen de ०\% tot Io०\%.

Tabel 7.12

Gevolgde cursussen en trainingen in 2004

$\begin{array}{lcc} & \text { Capaciteits- } & \text { Ondersteunende } \\ & \text { groepen } & \text { diensten } \\ & \% & \% \\ \text { Cursus in netwerk van promovendi } & 88 & - \\ \text { Cursus op vakgebied medewerker } & 29 & 84 \\ \text { Onderwijsvaardigheden } & 50 & 16 \\ \text { Managementtraining } & 54 & 53 \\ \text { Communicatieve vaardigheden } & 8 & 53 \\ \text { IT vaardigheden (t.b.v. onderwijs) } & 21 & - \\ \text { IT vaardigheden (algemeen) } & 8 & 47 \\ \text { Commerciële vaardigheden } & - & 9 \\ \text { Engels } & 38 & 25 \\ \text { Milieu en arbeidsomstandigheden op de werkplek } & 8 & 16 \\ \text { * Het betreft hier cursussen die WP'ers gevolgd hebben } & & \\ \text { - niet gevraagd } & & \end{array}$


In tabel 7.I2 wordt een overzicht gegeven van de soort cursussen die in 2004 volgens de beherend bazen het meest gevolgd werden. Bij de capaciteitsgroepen zijn met name de cursussen in het netwerk van promovendi populair. Maar liefst $88 \%$ van de beherend bazen geeft aan dat wetenschappelijk personeel in hun capaciteitsgroep dergelijke cursussen in 2004 gevolgd heeft. Daarnaast werden er veel managementtrainingen (54\%) en cursussen op het gebied van onderwijsvaardigheden (50\%) gevolgd. WP'ers volgen daarentegen vrijwel geen cursussen op het gebied van communicatieve vaardigheden, algemene IT vaardigheden en milieu en arbeidsomstandigheden op de werkplek.

Bij de ondersteunende diensten wordt het meest deelgenomen aan cursussen op het vakgebied van de medewerker (84\%). Daarnaast waren managementtrainingen (53\%), cursussen op het gebied van communicatieve vaardigheden (eveneens $53 \%$ ) en algemene IT vaardigheden (47\%) populair. Slechts $9 \%$ van de beherend bazen geeft aan dat hun personeel in 2004 vaak cursussen op het gebied van commerciële vaardigheden volgde.

Zijn de door medewerkers gevolgde cursussen ook de cursussen die de beherend bazen belangrijk vinden? Over het algemeen wel. Zo laat tabel 7.I3 zien dat nagenoeg alle beherend bazen van de capaciteitsgroepen vooral cursussen op het gebied van onderwijsvaardigheden en op het vakgebied van de medewerker belangrijk vinden voor hun wetenschappelijk personeel. Managementtraining wordt met name voor enkele WP'ers belangrijk geacht $(78 \%)$. Cursussen op het gebied van milieu en arbeidsomstandigheden op de werkplek worden daarentegen beduidend minder belangrijk gevonden.

Tabel 7.13

Belang van cursussen voor het WP bij de capaciteitsgroepen

$\begin{array}{lcccc} & \begin{array}{c}\text { Voor alle } \\ \text { WP'ers }\end{array} & \begin{array}{c}\text { Voor de meeste } \\ \text { WP'ers }\end{array} & \begin{array}{c}\text { Voor enkele } \\ \text { WP'ers }\end{array} & \begin{array}{c}\text { Niet } \\ \text { belangrijk } \\ \%\end{array} \\ \text { Cursus op vakgebied medewerker } & \% & \% & 39 & 4 \\ \text { Onderwijsvardigheden } & 35 & 22 & 42 & 0 \\ \text { Managementtraining } & 21 & 38 & 78 & 9 \\ \text { Communicatieve vaardigheden } & 0 & 13 & 55 & 30 \\ \text { IT vaardigheden (t.b.v. onderwijs) } & 14 & 18 & 55 & 32 \\ \text { IT vaardigheden (algemeen) } & 13 & 22 & 65 & 13 \\ \text { Engels } & 5 & 9 & 41 & 59 \\ \text { Milieu en arbeidsomstandigheden } & 17 & 4 & & \end{array}$

Bron: ROA/Enquête onder beherend bazen 2005

De beherend bazen van de ondersteunende diensten vinden eveneens cursussen op het vakgebied van de medewerker erg belangrijk (zie tabel 7.I4). Daarnaast worden cursussen in communicatieve vaardigheden en algemene IT vaardigheden door bijna alle beherend bazen als belangrijk bestempeld. Hetzelfde geldt voor managementtrainingen, maar deze wordt meer voor enkele medewerkers van belang geacht. Het minste belang wordt gehecht aan cursussen op het gebied van onderwijsvaardigheden 
of commerciële vaardigheden. $22 \%$ van de beherend bazen van de ondersteunende diensten noemt overigens nog andere cursussen die zij belangrijk vinden voor hun medewerkers. Het gaat dan vooral om cursussen projectmanagement en cursussen gericht op het werken in teams.

Tabel 7.14

Belang van cursussen voor medewerkers bij de ondersteunende diensten

\begin{tabular}{|c|c|c|c|c|}
\hline & $\begin{array}{c}\text { Voor alle } \\
\text { mede- } \\
\text { werkers } \\
\%\end{array}$ & $\begin{array}{l}\text { Voor de } \\
\text { meeste mede- } \\
\text { werkers } \\
\%\end{array}$ & $\begin{array}{c}\text { Voor enkele } \\
\text { mede-werkers } \\
\%\end{array}$ & Niet belangrijk \\
\hline Cursus op vakgebied medewerker & 39 & 29 & 32 & 0 \\
\hline Onderwijsvaardigheden & 5 & 10 & 38 & 48 \\
\hline Managementtraining & 0 & 0 & 100 & 0 \\
\hline Communicatieve vaardigheden & 39 & 23 & 39 & 0 \\
\hline IT vaardigheden (algemeen) & 26 & 23 & 48 & 3 \\
\hline Commerciële vaardigheden & 4 & 12 & 44 & 40 \\
\hline Engels & 28 & 35 & 24 & 14 \\
\hline Milieu en arbeidsomstandigheden & 17 & 17 & 46 & 21 \\
\hline
\end{tabular}

Bron: ROA/Enquête onder beherend bazen 2005

Tabel 7.15

Kwaliteit van de organisatie-eenheid (beoordeling door beherend bazen in de vorm van rapport cijfers)

$\begin{array}{lcc} & \begin{array}{c}\text { Capaciteitsgroepen } \\ \text { Gemiddelde }\end{array} & \begin{array}{c}\text { Ondersteunende diensten } \\ \text { Gemiddelde }\end{array} \\ \text { Vakspecifieke kennis } & 8,3 & 7,6 \\ \text { Onderzoekskwaliteiten } & 7,7 & . \\ \text { Onderwijskwaliteiten } & 7,7 & 6,8 \\ \text { Communicatieve vaardigheden } & 7,3 & 6,7 \\ \text { IT vaardigheden } & 7,2 & 5,8 \\ \text { Commerciële vaardigheden } & - & 6,4 \\ \text { Beheersing Engels } & 7,9 & 7,3 \\ \text { Zelfstandig werken } & - & 7,0 \\ \text { Werken in teamverband } & 7,5 & 7,0 \\ \text { Flexibiliteit } & 7,6 & 6,9 \\ \text { Initiatief } & 7,7 & 7,2 \\ \text { Leervermogen } & 7,7 & 7,0 \\ \text { Probleemoplossend vermogen } & - & 6,9 \\ \text { Procesgericht werken } & - & 7,0 \\ \text { Plannen en organiseren } & - & 7,2 \\ \text { Ondersteunende rol OBP } & 7,6 & 7,9 \\ \text { Algehele kwaliteit } & & 7\end{array}$

- niet gevraagd

Bron: ROA/Enquête onder beherend bazen 2005

Kortom, over het algemeen worden cursussen op het eigen vakgebied door de beherend bazen het meest belangrijk gevonden. Opvallend is dat zij tevens vinden dat hun personeel op dit gebied al goed scoort. Zo laat tabel 7.15 zien dat de beherend bazen van de capaciteitsgroepen hun personeel een ruime acht voor vakspecifieke kennis geven. De beherend bazen van de ondersteunende diensten waarderen de vakspe- 
cifieke kennis van hun personeel met een 7,6. Ook over de overige kwaliteiten van hun personeel zijn de beherend bazen tevreden, al zijn de leidinggevenden van de ondersteunende diensten wat kritischer. Met name op de commerciële vaardigheden $(5,8)$ en de beheersing van het Engels $(6,4)$ scoort het ondersteunend personeel maar net een voldoende. Ook wat betreft de IT vaardigheden en commerciële vaardigheden worden de medewerkers van de ondersteunende diensten niet zo hoog ingeschat. Het is dan ook niet vreemd dat juist de cursussen op deze gebieden door de beherend bazen belangrijk gevonden worden (zie tabel 7.I4).

\subsection{Ervaren belemmeringen bij personeelsbeleid}

Ten slotte is in de enquête onder beherend bazen gevraagd of zij belemmeringen ervaren bij het personeelsbeleid zoals ze dat graag willen voeren. Maar liefst $83 \%$ van de beherend bazen van de capaciteitsgroepen geeft aan dergelijke belemmeringen te ondervinden. Meerdere malen wordt hierbij genoemd dat er onvoldoende financiële middelen beschikbaar zijn voor een goed personeelsbeleid. Ook de starheid van het formatiebeginsel en de beperkte doorgroeimogelijkheden binnen de capaciteitsgroepen worden door meerdere beherend bazen als belemmering ervaren. Daarnaast worden zaken als bureaucratie, een te grote mate van top-down benadering van het bestuur en het HRM beleid van de UM in zijn algemeenheid genoemd. Dit zou geïnterpreteerd kunnen worden als een wens van de beherend bazen om meer invloed op het personeelsbeleid binnen de capaciteitsgroep te kunnen hebben en minder afhankelijk te zijn van het faculteits- of universiteitsbrede beleid. Zoals we al eerder zagen, vindt men daarbij vooral het faciliteren van onderzoek en onderwijs voor het wetenschappelijk personeel van belang.

De beherend bazen van de ondersteunende diensten geven minder vaak aan problemen op het gebied van het personeelsgebied te ondervinden, al zegt ook hier $63 \%$ van de beherend bazen bepaalde belemmeringen te ervaren. Deze belemmeringen hebben vooral te maken met een gebrek aan financiële middelen, zo blijkt uit de antwoorden. Ook onvoldoende flexibiliteit (bijvoorbeeld om tijdelijke krachten in te huren of slecht functionerende medewerkers te ontslaan) en de lage mobiliteit van medewerkers worden door meerdere beherend bazen als belemmering gezien. Ten slotte worden de conservatieve bedrijfscultuur, de starheid van de organisatie en de vele veranderingen die tegelijkertijd plaatsvinden als belangrijkste belemmeringen bij het personeelsbeleid genoemd.

\subsection{Samenvatting: indicatoren voor de HRM portfolio}

In dit hoofdstuk zijn een aantal facetten van het binnen de UM gevoerde HRM beleid aan de orde gekomen. We willen nu de belangrijkste indicatoren op dit terrein op een rijtje zetten. Deze indicatoren kunnen voor organisaties en/of organisatie-eenheden 
een hulpmiddel zijn om bepaalde doelen te stellen en deze te monitoren. Tezamen vormen de indicatoren een belangrijk onderdeel van de voorgestelde HRM portfolio.

\section{Tabel 7.16}

Indicatoren met betrekking tot het gevoerde HRM beleid

\begin{tabular}{|c|c|c|}
\hline & $\begin{array}{l}\text { Capaciteits- } \\
\text { groepen }\end{array}$ & $\begin{array}{l}\text { Ondersteunende } \\
\text { diensten }\end{array}$ \\
\hline \multicolumn{3}{|l|}{ Managementstijl (zelfrapportage score 1-5) } \\
\hline Consistent uitdragen van visie en strategie & 3,5 & 3,8 \\
\hline Draagvlak creëren voor beslissingen & 3,6 & 3,8 \\
\hline Waardering uiten voor successen in inspanningen & 3,4 & 3,8 \\
\hline Nee kunnen zeggen & 2,8 & 3,2 \\
\hline \multicolumn{3}{|l|}{ Werving en selectie } \\
\hline $\begin{array}{l}\% \text { vacatures dat moeilijk vervulbaar is } \\
\text { Alternatief: }\end{array}$ & * & * \\
\hline Organisatie-eenheden met moeilijk vervulbare vacatures (\%) & 40 & 40 \\
\hline \multicolumn{3}{|l|}{ Arbeidsvoorwaardenbeleid } \\
\hline \multicolumn{3}{|l|}{ Gratificaties: } \\
\hline $\begin{array}{l}\text { \% medewerkers dat een gratificatie ontvangt } \\
\text { Keuzemodel Arbeidsvoorwaarden UM: }\end{array}$ & 17 & 31 \\
\hline$\%$ medewerkers dat hiervan gebruik maakt & * & * \\
\hline \multicolumn{3}{|l|}{ Personeelsontwikkelingsbeleid } \\
\hline $\begin{array}{l}\text { Functioneringsgesprekken: } \\
\% \text { medewerkers met gesprekken } \\
\text { Alternatief: }\end{array}$ & * & * \\
\hline $\begin{array}{l}\text { Organisatie-eenheden met functioneringsgesprekken voor alle medewerkers } \\
\text { coaching: }\end{array}$ & 84 & 94 \\
\hline $\begin{array}{l}\text { \% medewerkers met coaching } \\
\text { Alternatief: }\end{array}$ & * & * \\
\hline $\begin{array}{l}\text { Organisatie-eenheden met coaching voor alle medewerkers } \\
\text { Persoonlijke ontwikkelingsplannen: }\end{array}$ & 13 & 16 \\
\hline $\begin{array}{l}\text { \% medewerkers met POP } \\
\text { Alternatief: }\end{array}$ & * & * \\
\hline $\begin{array}{l}\text { Organisatie-eenheden met POPs voor alle medewerkers } \\
\text { Internationale uitwisseling: }\end{array}$ & 15 & 28 \\
\hline $\begin{array}{l}\% \text { medewerkers dat is uitgewisseld } \\
\text { Internationale congressen: }\end{array}$ & * & * \\
\hline $\begin{array}{l}\text { \% medewerkers dat deelneemt } \\
\text { Alternatief: }\end{array}$ & * & * \\
\hline $\begin{array}{l}\text { Organisatie-eenheden waar alle medewerkers deelnemen aan internationale } \\
\text { congressen }\end{array}$ & 56 & - \\
\hline Scholing van medewerkers & & \\
\hline $\begin{array}{l}\text { Cursusparticipatie: } \\
\% \text { medewerkers dat cursussen volgt } \\
\text { Competenties: }\end{array}$ & 41 & 41 \\
\hline - Vakspecifieke kennis (rapportcijfer) & 8,3 & 7,6 \\
\hline - IT vaardigheden (rapportcijfer) & 7,2 & 6,7 \\
\hline - Beheersing Engels (rapportcijfer) & 7,9 & 6,4 \\
\hline
\end{tabular}

- onvoldoende waarnemingen; * wordt op dit moment nog niet verzameld

Bron: ROA/Enquête onder beherend bazen 2005 en SAP informatiesysteem UM 
Omdat niet over alle indicatoren informatie verzameld wordt, besteden we ook aandacht aan alternatieve indicatoren die op dit moment wel binnen de UM beschikbaar zijn. In de toekomst zou dan informatie verzameld kunnen worden voor de invulling van de overige indicatoren. Tabel 7.I6 geeft een overzicht van de belangrijkste HRM indicatoren voor zowel de capaciteitsgroepen als de ondersteunende diensten.

Over het wervings- en selectiebeleid van de UM is weinig bekend. Een goede indicator voor dit beleid zou het percentage vacatures dat met interne of externe kandidaten wordt opgevuld kunnen zijn. Hiervoor zijn in hoofdstuk 6 al een aantal indicatoren gepresenteerd voor de UD, UHD en hoogleraarsfuncties. Een tweede relevante indicator is het percentage moeilijk vervulbare vacatures. Informatie hierover ontbreekt echter op dit moment binnen de UM. Wel is in de enquête onder beherend bazen gevraagd of er de afgelopen twee jaar moeilijk vervulbare vacatures zijn geweest. Het percentage beherend bazen dat deze vraag bevestigend beantwoord ( $40 \%$ van zowel de capaciteitsgroepen als de ondersteunende diensten in 2005) zou daarmee een alternatieve indicator kunnen vormen.

Met betrekking tot het arbeidsvoorwaardenbeleid kan gekeken worden naar de mate waarin medewerkers gratificaties ontvangen. Uit gegevens van het SAP informatiesysteem blijkt dat $17 \%$ van de medewerkers in capaciteitsgroepen en $31 \%$ van de medewerkers in de ondersteunende diensten in 2005 een gratificatie gekregen hebben. Verder kan bekeken worden in hoeverre medewerkers gebruik maken van het Keuzemodel Arbeidsvoorwaarden UM. Dit wordt nu nog niet centraal bijgehouden, zodat we hierover geen uitspraken kunnen doen.

Het personeelsontwikkelingsbeleid kan op verschillende manieren in kaart gebracht worden. Zo vormen het percentage medewerkers dat functioneringsgesprekken voert, dat coaching krijgt en dat een persoonlijk ontwikkelingsplan (POP) heeft, drie belangrijke indicatoren. Omdat hierover binnen de UM geen structurele gegevens verzameld worden, is in de enquête onder beherend bazen gevraagd of deze HRM instrumenten voor alle medewerkers ingezet worden. De cijfers in de tabel laten zien dat de ondersteunende diensten hier beter op scoren dan de capaciteitsgroepen.

Daarnaast vormt internationalisering een belangrijk onderdeel van het algemene HRM beleid. In de eerste plaats gaat het dan om de internationale uitwisseling van medewerkers. Hierover is echter geen informatie beschikbaar. Ook het percentage medewerkers dat internationale congressen bezoekt, wordt niet structureel bijgehouden. Wel is in de enquête gevraagd of deelname aan internationale congressen voor alle medewerkers geldt. Dit blijkt bij 56\% van de capaciteitsgroepen het geval te zijn.

Een laatste terrein van het gevoerde HRM beleid omvat de scholing van medewerkers. Het percentage medewerkers dat aan een cursus deelneemt, is hiervoor een goede indicator. Uit de enquête onder beherend bazen blijkt dat $4 \mathrm{I} \%$ van de medewerkers in 
de capaciteitsgroepen en de ondersteunende diensten een cursus of training gevolgd heeft. Over het algemeen worden cursussen op het eigen vakgebied door de beherend bazen het meest belangrijk gevonden. Opvallend is dat zij tevens vinden dat hun personeel op dit gebied al goed scoort. Zo geven de beherend bazen van de capaciteitsgroepen hun medewerkers een ruime acht voor hun vakspecifieke kennis. De beherend bazen van de ondersteunende diensten waarderen de vakspecifieke kennis van hun personeel met een 7,6. Ook over de overige kwaliteiten van hun personeel zijn de beherend bazen tevreden, al zijn de leidinggevenden van de ondersteunende diensten wat kritischer. Met name op de commerciële vaardigheden $(5,8)$ en de beheersing van het Engels $(6,4)$ scoort het ondersteunend personeel maar net een voldoende. Ook wat betreft de IT vaardigheden worden de medewerkers van de ondersteunende diensten niet zo hoog ingeschat. Het is dan ook niet vreemd dat juist het volgen van cursussen op deze gebieden door de beherend bazen belangrijk gevonden worden (zie tabel 7.I4).

Ten slotte zou het goed zijn om in de HRM Portfolio UM indicatoren met betrekking tot de tevredenheid van werknemers op te nemen. In juni 2002 is door het IVA een personeelsenquête uitgevoerd, waarin zaken als werkbeleving en tevredenheid aan bod kwamen. Hieruit bleek dat medewerkers van de UM over het algemeen in ruime mate tevreden zijn over hun werk. De gegevens uit dit onderzoek zijn niet in deze HRM Portfolio gebruikt, omdat destijds is gesproken om de resultaten niet op decentraal niveau openbaar te maken. 


\section{Prestatiemaatstaven}

De performance van de UM wordt vanzelfsprekend primair bepaald door de prestaties op het terrein van onderwijs en onderzoek. Het HRM beleid ondersteunt het onderwijs en onderzoek op verschillende manieren. Zo wordt momenteel in het kader van het HRM programma onder andere aandacht besteed aan de professionalisering van docenten, aan de ontwikkeling van leidinggevende vaardigheden bij wetenschappers, aan de ontwikkeling van acquisitievaardigheden, en aan de ontwikkeling van begeleidingsvaardigheden bij hoogleraren en UHD's. Om het effect van dergelijke inspanningen op de performance te meten zijn er performance-indicatoren nodig. Deze indicatoren moeten niet alleen de output van onderwijs en onderzoek weergeven maar moeten deze output ook relateren aan de input in onderwijs en onderzoek. ${ }^{23}$

Verder is het van belang dat er voor deze indicatoren steeds een benchmark is. De performance van een faculteit op het gebied van onderwijs en onderzoek moet met name vergeleken worden met de performance van dezelfde faculteiten aan andere universiteiten. Er bestaan immers aanmerkelijke verschillen in publicatiegedrag tussen vakgebieden. Bovendien concurreren verschillende opleidingen binnen een universiteit minder om studenten dan gelijksoortige opleidingen aan verschillende universiteiten. De performance van een capaciteitsgroep of onderzoeksinstituut moet wel weer kunnen worden vergeleken met de performance van andere capaciteitsgroepen binnen dezelfde faculteit. Om het effect van bepaalde HRM instrumenten op de onderzoek- en onderwijsprestaties van een bepaalde faculteit of capaciteitsgroep te meten is het eveneens van belang dat een performance-indicator over een langere periode kan worden berekend. Ten slotte is het ook van belang om aandacht te hebben voor individuele prestaties van medewerkers op het gebied van onderwijs en onderzoek, omdat juist het verbeteren van de individuele prestaties binnen de mogelijkheden van het HRM beleid ligt.

In dit hoofdstuk wordt een overzicht gegeven van mogelijke performance-indicatoren op het gebied van onderwijs en onderzoek in de economische literatuur. In paragraaf 8.I wordt een overzicht gegeven van de indicatoren die de onderwijsprestaties van de verschillende faculteiten in beeld brengen. Daarbij wordt zowel gekeken naar het interne en externe rendement, als naar de kwaliteit van het gegeven onderwijs en de

23. Zie G. Johnes, "Performance Indicators in Higher Education: A Survey of Recent Work", Oxford review of Economic Policy, vol. 8, no. 2, 1995. 
wervingskracht van het onderwijs aan de UM. Vervolgens wordt in paragraaf 8.2 ingegaan op de indicatoren die de onderzoeksperformance in kaart brengen.

Zoals in hoofdstuk 3 reeds werd aangegeven wordt er met name op facultair niveau veel informatie verzameld met betrekking tot de onderwijs- en onderzoeksprestaties. Er is hier, zoals gezegd, sprake van separate informatiesystemen, die een vergelijking tussen faculteiten niet mogelijk maken. In dit hoofdstuk zullen we naast de op centraal niveau beschikbare gegevens, alleen gebruik maken van de onderwijs- en onderzoeksinformatie die beschikbaar is bij de economische faculteit, omdat we niet konden beschikken over de bij de andere faculteiten beschikbare data.

\subsection{Onderwijsperformance}

De performance van het onderwijs kan vanuit verschillende invalshoeken worden bekeken. Ramaekers en van der Velden ${ }^{24}$ richten zich op zowel de doeltreffendheid als de doelmatigheid van de opleiding. De doeltreffendheid van het onderwijs is de mate waarin het onderwijs de functies vervult die haar worden toegeschreven. De doelmatigheid heeft betrekking op de efficiëntie waarmee het onderwijs deze functies vervult. De belangrijkste functies van het onderwijs die daarbij kunnen worden onderscheiden zijn de kwalificatiefunctie, de selectiefunctie en de allocatiefunctie. Heeft het onderwijs studenten uitgerust met competenties die relevant zijn voor de doorstroming naar de arbeidsmarkt? Selecteert het onderwijs studenten op basis van hun competenties? Is er een optimale allocatie van studenten/afgestudeerden naar de arbeidsmarkt en naar vervolgopleidingen?

Voor het HRM beleid is vooral de doelmatigheid van deze functies van belang. Deze komt tot uitdrukking in het leerrendement, het interne rendement en het externe rendement. Bij het leerrendement gaat het om de toename van de kennis en vaardigheden van studenten als gevolg van de opleiding en de efficiency waarmee dat is gebeurd. ${ }^{25}$ Deze toename is echter niet goed te meten omdat over het algemeen niet precies bekend is welk niveau van kennis en vaardigheden studenten aan het begin van de studie hadden. Bij het interne rendement gaat het om de slagingskans en de studieduur. Voor het externe rendement moeten de individuele opbrengsten en kosten van de opleiding tegen elkaar worden afgezet.

Vanuit het oogpunt van performance is niet alleen het rendement van de opleiding belangrijk maar ook de kwaliteit van het onderwijsproces zelf van belang. Het gaat dan bijvoorbeeld om de kwaliteit van de docenten. Dit laatste aspect is met name een

24. G. Ramaekers en R. van der Velden, De ontwikkeling van een indicatorenstelsel voor de kwaliteit van het onderwijs, ROA, Maastricht, 2005.

25. Higher Education Funding Council for England, Performance Indicators in Higher Education, First report of the Performance Indicators Steering Group (PSIG), 99/II I999. 
aandachtspunt voor het HRM beleid, omdat hier op individueel niveau sturend kan worden opgetreden.

\section{Interne rendement}

In de economische literatuur wordt meestal gekeken naar het aantal studenten dat de studie succesvol met een diploma afsluit. ${ }^{26}$ De performance kan dan worden geïndiceerd door het aantal gediplomeerden per instroomcohort te relateren aan de omvang van dat cohort. Een nadeel van een dergelijke performance-indicator is dat ze tot op zekere hoogte te manipuleren is door de studienormen te verlagen. Ook wordt er niet gekeken naar eventuele verschillen in de kwaliteit van de afgestudeerden. Hier kan in principe voor gecorrigeerd worden door rekening te houden met de afstudeercijfers $^{27}$, maar ook deze cijfers zijn manipuleerbaar en kunnen daarom niet goed tussen verschillende opleidingen worden vergeleken. Voor de UM zijn interne rendementcijfers per faculteit bekend.

\section{Tabel 8.1}

Propedeuserendement en studierendement per faculteit

\begin{tabular}{|c|c|c|c|c|c|c|c|c|}
\hline & $94 / 95$ & $95 / 96$ & $96 / 97$ & $97 / 98$ & $98 / 99$ & $99 / 00$ & $00 / 01$ & $01 / 02$ \\
\hline & $\%$ & $\%$ & $\%$ & $\%$ & $\%$ & $\%$ & $\%$ & $\%$ \\
\hline \multicolumn{9}{|c|}{ Propedeuserendement (na 2 jaar) } \\
\hline FdAW & & & 71 & 76 & 77 & 42 & 62 & * \\
\hline $\mathrm{FdC}$ & 62 & 58 & 60 & 58 & 55 & 55 & 51 & 51 \\
\hline FdEWB & 64 & 59 & 61 & 61 & 59 & 63 & 60 & 58 \\
\hline FdG & 94 & 97 & 96 & 97 & 94 & 93 & 95 & 95 \\
\hline FdGW & 82 & 85 & 79 & 80 & 77 & 75 & 76 & 85 \\
\hline $\mathrm{FdP}$ & & 54 & 57 & 65 & 51 & 42 & * & 59 \\
\hline \multirow[t]{3}{*}{ FdR } & 69 & 67 & 70 & 65 & 65 & 57 & 53 & 48 \\
\hline & \multicolumn{8}{|c|}{ Studierendement (na 6 jaar) } \\
\hline & na $6 \mathrm{jr}$ & na $6 \mathrm{jr}$ & na $6 \mathrm{jr}$ & na $6 \mathrm{jr}$ & na $6 \mathrm{jr}$ & na $6 \mathrm{jr}$ & na $6 \mathrm{jr}$ & na $6 \mathrm{jr}$ \\
\hline FdAW & & & 50 & - & * & * & . & . \\
\hline $\mathrm{FdC}$ & 34 & 29 & 38 & 35 & * & $*$ & . & . \\
\hline FdEWB & 48 & 44 & 47 & 46 & * & * & . & . \\
\hline FdG & 88 & 86 & 84 & 87 & * & * & . & . \\
\hline FdGW & 57 & 58 & 52 & 52 & * & * & . & . \\
\hline $\mathrm{FdP}$ & - & 38 & 39 & 45 & * & * & . & . \\
\hline $\mathrm{FdR}$ & 46 & 44 & 47 & 40 & * & * & . & . \\
\hline
\end{tabular}

26. A. T. Flegg, D. O. Allen, K. Field, en T. W. Thurow, Measuring the Efficiency and Productivity of British Universities: An Application of DEA and the Malmquist Approach, University of the West of England, School of Economics, Discussion paper number 0304, 2003, P. A. Stevens, The Determinants of Economic Efficiency in English and Welsh Universities, National Institute of Economic and Social Rsearch, discussion paper number 185, september,200I.

27. Zie G. Johnes, "Performance Indicators in Higher Education: A Survey of Recent Work", Oxford review of Economic Policy, vol. 8, no. 2, 1995. 
Tabel 8.I geeft voor de UM faculteiten een overzicht van het propedeuserendement na 2 jaar en het doctoraalrendement na zes jaar. De tabel laat zien dat er tussen de faculteiten grote verschillen zijn in het interne rendement. Bij de geneeskundefaculteit is zowel het propedeuserendement als het studierendement het hoogst. Bij de rechtenfaculteit is het propedeuserendement daarentegen het laagst, terwijl de faculteit cultuurwetenschappen het laagste studierendement heeft. Met name bij de kleinere faculteiten blijken de interne rendementscijfers aanzienlijk te fluctueren

Omdat de rendementen niet alleen van de onderwijsprestaties afhangen, maar ook van de moeilijkheidsgraad van de studie en de studenten die aan de studie beginnen, zeggen verschillen in het interne rendement tussen faculteiten niet zo heel veel. Verschillen in rendement tussen min of meer dezelfde opleidingen aan verschillende universiteiten geven een beter inzicht in de performance van een faculteit. Tabel 8.2 vergelijkt de propedeuse- en studierendementen van de UM faculteiten met de landelijke cijfers. ${ }^{28}$ De tabel laat zien dat vooral de FdEWB, de FdG en de FdR erg goed scoren ten opzichte van het landelijke gemiddelde.

Tabel 8.2

Propadeuserendement en studierendement UM in vergelijking met het landelijk beeld

\begin{tabular}{|c|c|c|c|c|c|c|c|}
\hline \multirow[b]{2}{*}{ Faculteit } & \multirow[b]{2}{*}{ Opleiding } & \multicolumn{2}{|c|}{ UM } & \multicolumn{2}{|c|}{ Landelijk } & \multicolumn{2}{|c|}{ Verschil } \\
\hline & & $\begin{array}{l}\text { P2 } \\
\%\end{array}$ & $\begin{array}{l}\text { S6 } \\
\%\end{array}$ & $\begin{array}{l}\text { P2 } \\
\%\end{array}$ & $\begin{array}{l}\text { S6 } \\
\%\end{array}$ & $\begin{array}{l}\text { P2 } \\
\%\end{array}$ & $\begin{array}{l}\text { S6 } \\
\%\end{array}$ \\
\hline FdAW & Kennistechnologie & 61 & - & - & - & - & - \\
\hline $\mathrm{FdCW}$ & Cultuur- en Wetenschapsstudies & 66 & 39 & - & - & - & - \\
\hline \multirow[t]{4}{*}{ FdEWB } & Economie & 66 & 54 & 59 & 40 & 7 & 14 \\
\hline & Econometrie & 65 & 42 & 63 & 43 & 2 & -1 \\
\hline & Fiscale Economie & 60 & - & 47 & 29 & 13 & - \\
\hline & Bedrijfskunde & 70 & 53 & 60 & 36 & 10 & 17 \\
\hline FdG & Geneeskunde & 95 & 90 & 85 & 73 & 10 & 17 \\
\hline \multirow[t]{2}{*}{ FdGW } & Gezondheidswetenschappen & 81 & 58 & - & - & - & - \\
\hline & Milieugezondheidkunde & 92 & - & - & - & - & - \\
\hline FdP & Psychologie & 60 & 49 & 60 & 44 & 0 & 5 \\
\hline \multirow[t]{3}{*}{$\mathrm{FdR}$} & European law school & 65 & - & - & - & - & - \\
\hline & Fiscaal-juridische opleiding & 83 & 44 & 69 & 43 & 14 & 1 \\
\hline & Nederlands Recht & 69 & 54 & 61 & 39 & 8 & 15 \\
\hline
\end{tabular}

$P_{2}$ is het gemiddelde propedeuserendement na 2 jaar voor de cohorten 97/98 - 99/00

P6 is het gemiddelde studierendement na 6 jaar voor de cohorten 93/94 - 95/96 Bron: UM

Naast het studierendement is ook de gemiddelde studieduur een indicator voor het interne rendement van de opleiding (tabel 8.3). De gemiddelde studieduur lijkt, zoals verwacht, vooral samen te hangen met de nominale studieduur. Bij de opleiding tot basisarts is de gemiddelde studieduur daarom het hoogst en bij de korte opleiding gezondheidswetenschappen het laagst. Verder zijn er tussen de faculteiten weinig structurele verschillen in de gemiddelde studieduur. Er zijn helaas geen gege-

28. Om een landelijke vergelijking mogelijk te maken wordt in deze tabel een iets andere definitie voor studierendement gehanteerd, dus de cijfers van tabel 8.I en tabel 8.2 zijn niet direct vergelijkbaar. 
vens beschikbaar om de studieduur per faculteit te vergelijken met de studieduur van dezelfde faculteiten aan andere universiteiten. Een vergelijking per HOOP gebied is wel te maken. Een dergelijke vergelijking is echter voor de UM minder bruikbaar omdat een groot deel van de verschillen tussen de UM en het landelijk totaal voortkomen uit het feit dat onder een bepaald HOOP gebied veel meer opleidingen vallen dan aan de UM voorkomen.

Tabel 8.3

Gemiddelde studieduur per faculteit, cohorten 1999/00-2002/03 (in jaren)

$\begin{array}{llllll}\text { Faculteit } & \text { Opleiding } & 99 / 00 & 00 / 01 & 01 / 02 & 02 / 03 \\ \text { FdAW } & \text { Kennistechnologie } & & & \\ \text { FdCW } & \text { Cultuur en wetenschapstudies } & 4,2 & & & \\ \text { FdEWB } & \text { Economie } & 5,8 & 5,4 & 5,3 & 5,7 \\ & \text { Econometrie } & 5,2 & 5,3 & 5,2 & 5,3 \\ & \text { Fiscale economie } & 5,3 & 5,7 & 5,2 & 5,8 \\ & \text { Internationale Bedrijfkunde } & 4,0 & 4,7 & 4,9 & 4,5 \\ \text { FdG } & \text { Geneeskunde } & 5,0 & 5,2 & 5,2 & 5,2 \\ & \text { Basisarts } & 4,5 & 4,5 & 4,5 & 4,5 \\ \text { FdGW } & \text { Gezondheidswetenschappen (vt) } & 6,3 & 6,4 & 6,3 & 6,3 \\ & \text { Gezondheidswetenschappen (dt) } & 5,0 & 5,1 & 5,0 & 5,3 \\ \text { FdP } & \text { Gezondheidswetenschappen (kort) } & 3,9 & 4,2 & 4,4 & 4,2 \\ \text { FdR } & \text { Psychologie } & 3,0 & 2,7 & 2,7 & 3,1 \\ & \text { Nederlands Recht } & 4,7 & 4,3 & 4,7 & 5,0 \\ & \text { Fiscaal Recht } & 5,5 & 5,5 & 5,3 & 5,2 \\ & \text { European Law School } & 5,2 & 5,0 & 5,5 & 5,2 \\ & & 4,8 & 4,8 & 4,6 & 4,8\end{array}$

\section{Extern rendement}

Recentelijk heeft het ROA op basis van het afgestudeerdenonderzoek in het kader van de WO monitor het externe rendement van de UM faculteiten op basis van de volgende indicatoren in kaart gebracht:

- het werkloosheidspercentage $\mathrm{I}^{1} / 2$ jaar na het verlaten van de opleiding;

- het bruto uurloon $\mathrm{I}^{1} / 2$ na het verlaten van de opleiding;

- de carrièremogelijkheden van de functie.

Uit tabel 8.4 blijkt dat vooral de geneeskundefaculteit een hoog extern rendement heeft. Afgestudeerden van deze faculteit hebben de grootste kans op een baan, het hoogste bruto uurloon en de beste carrièremogelijkheden. Bij de faculteit psychologie is het externe rendement het minst gunstig: afgestudeerden hebben een kleinere kans op werk en verdienen gemiddeld een laag uurloon.

Ook voor het externe rendement geldt echter dat een vergelijking tussen soortgelijke opleidingen aan verschillende universiteiten een betere indicatie geeft van de onderwijsperformance dan een vergelijking tussen faculteiten. De verschillen tussen faculteiten kunnen immers voor een groot deel worden verklaard door de aard van de opleiding en de arbeidsmarktsituatie voor de desbetreffende opleiding. Uit de tabel blijkt 
dat afgestudeerden van vier van de vijf faculteiten van de UM een kleinere kans op werk hebben dan de afgestudeerden van deze faculteiten aan de andere universiteiten. Alleen bij de afgestudeerden van de FdGW ligt de werkloosheid op een lager niveau dan landelijk. Afgestudeerden van de faculteiten Psychologie en Rechten verdienen ook minder dan het landelijk gemiddelde voor deze faculteiten. Bij Geneeskunde en Gezondheidswetenschappen verdienen de afgestudeerden daarentegen meer dan het landelijk gemiddelde. Bij drie faculteiten van de UM hebben de afgestudeerden betere carrièremogelijkheden dan de afgestudeerden van dezelfde faculteiten van andere universiteiten. Met name de afgestudeerden van de faculteit Psychologie hebben veel betere carrièremogelijkheden. De totaalscores van het externe rendement geven aan dat de faculteiten Rechten en Economie achterblijven bij het landelijke beeld, terwijl de faculteiten Geneeskunde, Gezondheidswetenschappen en Psychologie het beter doen.

Tabel 8.4

Indicatoren voor het externe rendement na 11/2 jaar, gemiddelde 2003 en 2004

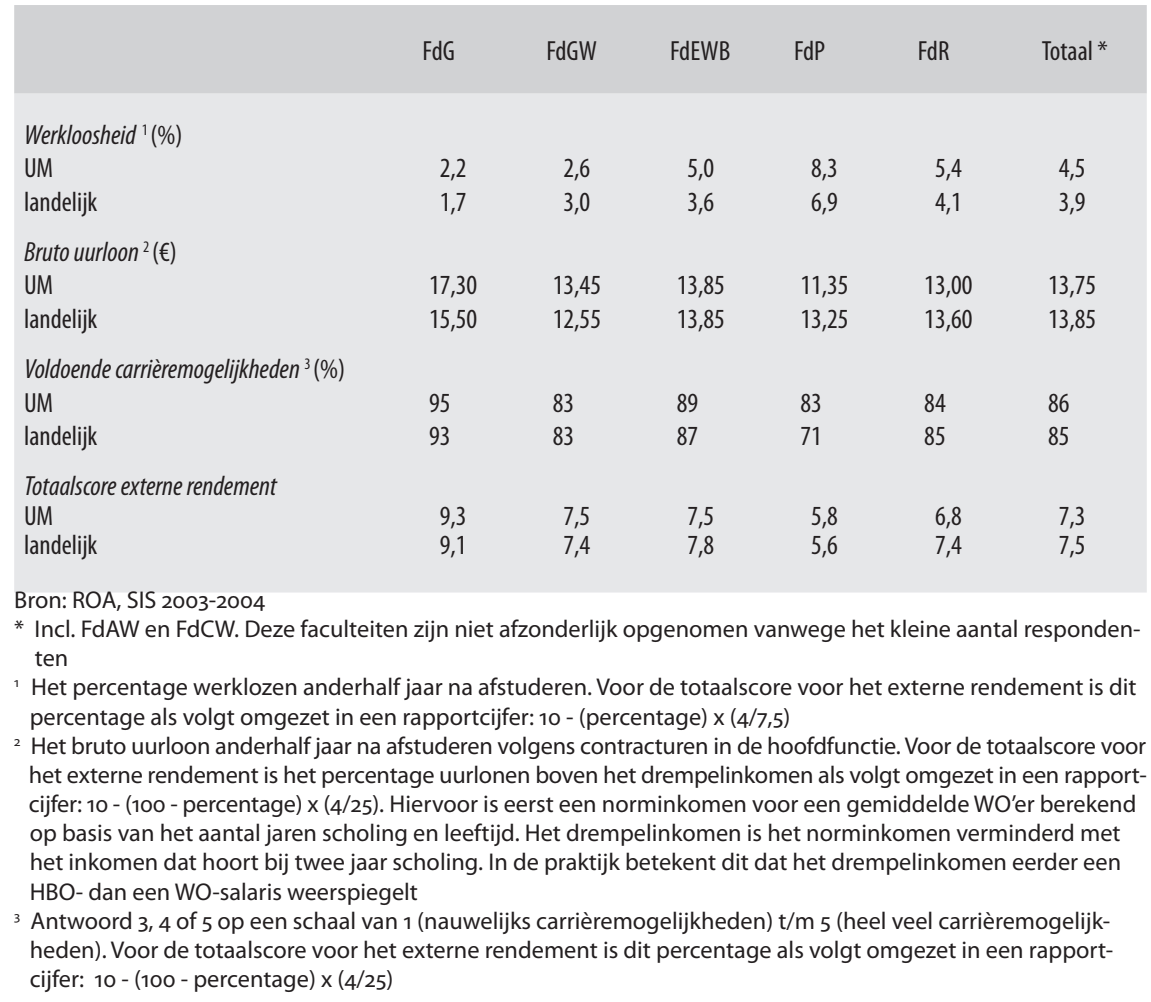




\section{Onderwijsproces}

Voor de performance op het gebied van onderwijs is vanzelfsprekend ook de kwaliteit van het onderwijsproces zelf van belang. Het gaat dan om zaken als de leeromgeving, de inrichting van de opleiding en de kwaliteit van de docenten. Dit is bij uitstek een gebied waarop individuele prestaties van docenten kunnen worden gemeten en het HRM beleid zijn vruchten zou kunnen afwerpen.

\section{Tabel 8.5}

Aandachtspunten in de cursusevaluatie van de FdEWB

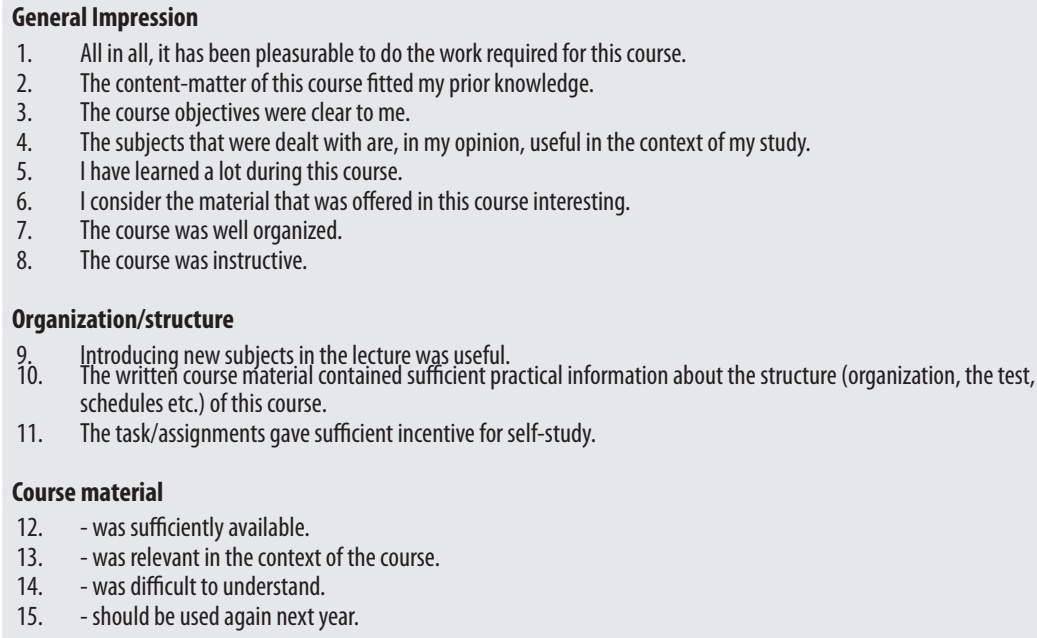

Organization/structure

9. Introducing new subjects in the lecture was useful.

10. The written course material contained sufficient practical information about the structure (organization, the test, schedules etc.) of this course.

11. The task/assignments gave sufficient incentive for self-study.

\section{Course material}

12. - was sufficiently available.

13. - was relevant in the context of the course.

14. - was difficult to understand.

15. - should be used again next year.

\section{Assignments}

16. Clear information was available on how to approach the assignments.

17. The instructor(s) provided adequate feedback on the assignments.

18. Working on the assignments was instructive.

\section{Overall questions}

19. How many hours per week on the average (excluding contact hours) did you spend on self-study (presentations, cases, assignments, studying literature, etc)?

20. Please give an overall grade for the quality of this course ( $1=$ very bad, $6=$ sufficient, $10=$ very good)?

\section{Instructor: Name}

23. - was able to explain things in an understandable way.

24. - gave the impression to be motivated.

25. - stimulated self-study.

26. Give a grade for the overall functioning of the instructor on a ten-point scale. (1=extremely poor, $6=$ pass, $10=$ extremely good).

In de meeste faculteiten wordt na afloop van een cursus het onderwijs geëvalueerd door de studenten. Tabel 8.5 geeft een overzicht van de aandachtspunten in het evaluatieformulier dat wordt gebruikt aan de economische faculteit. Per item kunnen de studenten op een schaal van één tot vijf aangeven in hoeverre dat item voor hun cursus van toepassing was. Daarnaast kunnen ze een totaalcijfer geven voor de kwaliteit van 
de cursus (item 20) en voor de tutor (item 26). Deze laatste twee gegevens zouden kunnen worden gebruikt om op verschillende niveaus een performance-indicator te construeren. Per capaciteitsgroep ('departement') kan bijvoorbeeld een (gewogen) gemiddelde van het totaalcijfer voor de kwaliteit van de cursussen die vanuit de desbetreffende capaciteitsgroep in een studiejaar worden verzorgd als indicator worden genomen voor de kwaliteit van het geleverde onderwijs. Daarnaast zou per tutor het (gewogen) gemiddelde kunnen worden berekend van de tutorbeoordelingen van alle onderwijsgroepen die hij of zij in een studiejaar heeft verzorgd.

De meer specifieke items in het onderwijsevaluatieonderzoek maken het ook mogelijk om specifieke knelpunten te achterhalen, waar het HRM beleid zich op zou kunnen richten. Idealiter zouden op ale faculteiten gedeeltelijk dezelfde vragen moeten worden gesteld, zodat de onderwijsprestaties tussen faculteiten vergeleken kunnen worden. Een voorwaarde is echter wel dat de evaluatiegegevens kunnen worden gekoppeld aan persoonsgegevens. Dat is nu nog niet goed mogelijk, omdat niet goed wordt bijgehouden welke tutoren welke onderwijsgroep geven.

Tabel 8.6 geeft een overzicht van het gemiddelde totaaloordeel van de studenten over de kwaliteit van het onderwijs van de diverse capaciteitsgroepen aan de FdEWB. De gemiddelde score per vak is hierbij steeds gewogen met het aandeel van dit vak in de totale onderwijslast van de capaciteitsgroep. ${ }^{29}$ De tabel laat zien dat de verschillen in onderwijsperformance op basis van deze indicator klein zijn. De vakgroep Kwantitatieve economie scoort iets minder goed dan de andere capaciteitsgroepen. Daarbij moet wel bedacht worden dat vanuit deze capaciteitsgroep veelal de zwaardere vakken worden verzorgd, waardoor het oordeel over de vakken mogelijk negatief beïnvloed wordt. Dit wijst er op dat het moeilijk is op dit punt een vergelijking te maken tussen de verschillende capaciteitsgroepen. Daarom is het waarschijnlijk beter om de aandacht primair te richten op de jaarlijkse ontwikkeling van deze indicator.

Tabel 8.6

Waardering voor het onderwijs per capaciteitsgroep (studentenoordeel) aan de faculteit Economie en Bedrijfswetenschappen, studiejaar 2003/2004

$\begin{array}{lr}\text { Accountancy \& Informatie management } & 7,0 \\ \text { Algemene economie } & 7,0 \\ \text { Financiering } & 7,3 \\ \text { Kwantitatieve Economie } & 6,5 \\ \text { Marketing } & 7,2 \\ \text { Organisatie \& Strategie } & 7,0\end{array}$

29. Als een vak vanuit meerdere capaciteitsgroepen wordt verzorgd, dan krijgen al deze capaciteitsgroepen voor dit vak hetzelfde cijfer, omdat het op basis van de beschikbare data nog niet mogelijk was om voor iedere capaciteitsgroep die aan het vak meewerkt een afzonderlijk gemiddelde uit te rekenen. 
Studentenoordelen over het onderwijs spelen ook een belangrijke rol bij het studentenonderzoek van Elsevier en bij het onderzoek van de Keuzegids Hoger Onderwijs. ${ }^{30}$ In deze onderzoeken worden gelijke opleidingen aan verschillende universiteiten vergeleken. Bij het onderzoek van de Keuzegids Hoger Onderwijs wordt naast het oordeel van studenten ook het oordeel van deskundigen betrokken. Beide onderzoeken geven inzicht in de kwaliteit van het onderwijsproces. Er wordt gekeken naar de kwaliteit van docenten, de kwaliteit van colleges, de faciliteiten, de organisatie en communicatie, etcetera. Deze beoordelingen geven goed inzicht in de zwakke en sterke punten van opleidingen en geven aanknopingspunten voor verbeteringen.

Ten slotte worden opleidingen regelmatig extern beoordeeld door een onafhankelijke, externe commissie. Deze visitatiecommissie heeft als taak de opleiding te beoordelen, adviezen te geven, de opleiding te vergelijken met andere opleidingen en de buitenwereld over de kwaliteit van de opleidingen te informeren. Het visitatieverslag geeft heel uitvoerig informatie over de verschillende aspecten van het onderwijs en geeft een vergelijking van de performance van gelijke opleidingen aan verschillende faculteiten.

\section{Overige performance indicatoren}

Naast bovengenoemde performance indicatoren die betrekking hebben op het interne en externe rendement van de opleiding en het onderwijsproces zijn er nog een aantal belangrijke indicatoren met betrekking tot de wervingskracht van het onderwijs aan de UM. Voorbeelden hiervan zijn de ontwikkeling van de instroom van eerstejaars studenten en de relatieve instroom van buitenlandse studenten.

\section{Tabel 8.7}

Instroom van eerstejaars studenten per faculteit (index 1999=100).

\begin{tabular}{|c|c|c|c|c|c|c|}
\hline & 1999 & 2000 & 2001 & 2002 & 2003 & 2004 \\
\hline \multicolumn{7}{|l|}{ Faculteit } \\
\hline FdAW & 100 & 132 & 68 & 59 & 32 & 92 \\
\hline $\mathrm{FdCW}$ & 100 & 99 & 91 & 318 & 367 & 444 \\
\hline FdEWB & 100 & 93 & 96 & 92 & 89 & 94 \\
\hline $\mathrm{FdG}$ & 100 & 102 & 109 & 145 & 155 & 157 \\
\hline FdGW & 100 & 97 & 100 & 89 & 83 & 78 \\
\hline $\mathrm{FdP}$ & 100 & 102 & 113 & 104 & 97 & 117 \\
\hline $\mathrm{FdR}$ & 100 & 89 & 88 & 71 & 77 & 73 \\
\hline $\mathrm{UCM}^{*}$ & & & & $100^{*}$ & 121 & 147 \\
\hline Totaal & 100 & 96 & 97 & 102 & 102 & 109 \\
\hline
\end{tabular}

30. F. Steenkamp, A. de Moor en M. van Beek (redactie), Keuzegids Hoger Onderwijs 04/05, Uitgeverij EPN, Houten, 2004, E.E. Berkhout, P.H.G. Berkhout, M.L. Biermans, Studie \& Werk 2005, rapport nr. 808, SEO, Amsterdam, 2005. 
Tabel 8.7 geeft een overzicht van de ontwikkeling van de studenteninstroom in de verschillende faculteiten tussen 1999 en 2004 . De tabel laat zien dat de toename van de studenteninstroom zich concentreert bij de faculteiten Cultuurwetenschappen en Geneeskunde en het UCM. Daarentegen is er met name in de faculteiten Rechten en Gezondheidswetenschappen sprake van een krimpende instroom van eerstejaars studenten.

Tabel 8.8 geeft een overzicht van het aandeel van de buitenlandse studenten in de eerstejaars instroom van de verschillende faculteiten. Uit de tabel blijkt dat drie faculteiten en het UCM reeds meer dan 40\% van hun eerstejaars instroom uit het buitenland weten aan te trekken. Daarentegen staat de internationalisering van de studenteninstroom bij de faculteiten Geneeskunde, Gezondheidswetenschappen en Rechten nog op een laag pitje.

Tabel 8.8

Percentage (reguliere) buitenlandse studenten van de instroom per faculteit

\begin{tabular}{|c|c|c|c|c|c|}
\hline Faculteit & $\begin{array}{c}1999 \\
\%\end{array}$ & $\begin{array}{c}2000 \\
\%\end{array}$ & $\begin{array}{c}2001 / 02 \\
\%\end{array}$ & $\begin{array}{c}2002 / 03 \\
\%\end{array}$ & $\begin{array}{c}2003 / 04 \\
\%\end{array}$ \\
\hline $\mathrm{FdCW}$ & 34 & 24 & 14 & 43 & 51 \\
\hline FdEWB & 34 & 37 & 42 & 38 & 48 \\
\hline FdG & 6 & 7 & 7 & 7 & 4 \\
\hline FdGW & 3 & 5 & 9 & 13 & 10 \\
\hline $\mathrm{FdP}$ & 24 & 28 & 34 & 30 & 41 \\
\hline $\mathrm{FdR}$ & 9 & 9 & 16 & 15 & 14 \\
\hline UCM & & & & 40 & 42 \\
\hline Buitenlandse studenten & 18 & 20 & 24 & 26 & 30 \\
\hline
\end{tabular}

\subsection{Onderzoeksperformance}

Bij het meten van de onderzoeksperformance is zowel de wetenschappelijke kwaliteit van het onderzoek als de maatschappelijke relevantie van belang. Beide aspecten van het onderzoek aan universiteiten zijn echter niet altijd complementair. ${ }^{31}$ Een te groot accent op de maatschappelijke relevantie kan ten koste gaan aan de wetenschappelijke kwaliteit en vice versa. Hoe de verhouding tussen wetenschappelijke en maatschappelijke output zou moeten liggen is afhankelijk van de doelstellingen van de UM en niet a priori vast te leggen.

In de literatuur worden verschillende outputindicatoren voor onderzoek onderscheiden. De meest genoemde indicatoren zijn de bibliometrische indicatoren, zoals

3I. J. D. Foltz, B. L. Barham en K. Kim, Synergies or Tradeoffs in University Life Sciences Research, Mimeo, July 2003 . 
het aantal publicaties per faculteit of capaciteitgroep en het aantal citaties. ${ }^{32}$ De wetenschappelijke waarde van het onderzoek blijkt vooral uit de wetenschappelijke publicaties en de maatschappelijke relevantie uit de vakpublicaties. Vaak worden de publicaties ook gewogen op basis van de impactscores van tijdschriften, waarin artikelen worden gepubliceerd.

Naast de bibliometrische indicatoren wordt bij de natuurwetenschappen ook het aantal patenten vaak als outputindicator voor het verrichte onderzoek gehanteerd. ${ }^{33}$ Het nadeel van al deze outputindicatoren is dat ze vooral wat zeggen over de prestaties in het verleden, omdat er altijd enige tijd over heen gaat voordat een onderzoek wordt gepubliceerd of een patent wordt toegekend. Bovendien wordt niet in elk vakgebied evenveel waarde gehecht aan publicaties. Om die reden worden ook nog niet gepubliceerde papers en congresbezoek wel eens meegerekend. ${ }^{34}$ Het is echter meestal onduidelijk wat de kwaliteit van ongepubliceerd werk is.

Voor de UM is op basis van het METIS systeem per faculteit informatie beschikbaar over het aantal publicaties. Daarbij kan er een onderscheid worden gemaakt tussen wetenschappelijke publicaties en publicaties in vaktijdschriften. Bij de wetenschappelijke publicaties kan bovendien een onderscheid worden gemaakt tussen wetenschappelijke tijdschriften, waarin de artikelen zijn 'gerefereed' en tijdschriften waarin de artikelen niet zijn gerefereed. Er wordt echter geen onderscheid gemaakt tussen publicaties in internationale wetenschappelijke tijdschriften en publicaties in Nederlandse tijdschriften.

Om een idee te krijgen van de onderzoeksperformance moet de onderzoeksoutput vanzelfsprekend worden gerelateerd aan de onderzoeksinzet. Voor de UM is per faculteit de onderzoeksinput in mensjaar equivalenten bekend. Het gaat dan om de inzet van wetenschappelijk personeel waarbij een correctie wordt gemaakt voor de inzet in het onderwijs. ${ }^{35}$ Voor de FdEWB geldt bijvoorbeeld de volgende correctie: een hoogleraar, UHD en UD telt mee voor $40 \%$, een $\mathrm{AIO}$ voor $70 \%$ en een post-doc of onderzoeker voor I00\%. Een performance-indicator wordt verkregen door het aantal publicaties te delen door de onderzoeksinput.

32. Zie bijvoorbeeld:

- G. Johnes en J. Johnes, "Measuring the Research Performance of UK Economic Departments: An Application of Data Envelopment Analysis", Oxford Economic Papers, no 45, pp 332-347, 1993.

- A. A. Payne en A. Siow, "Does federal Research Funding Increase University Research output?", Advances in Economic Analysis \& Policy, vol. 3, no. I, pp I-22, 2003.

- G. Crespi and A. Geuna, Modelling and measuring Scientific Production: Results for a panel of OECD Countries, Science and Technology Research, paper no. 133. 2005.

33. A. A. Payne en A. Siow, "Does federal Research Funding Increase University Research output?", Advances in Economic Analysis \& Policy, vol. 3, no. I, pp I-22, 2003.

34. M. Abobott en H. Doucouliagos, "Research Output of Australian Universities", Education Economics, vol. I2, no. 3, December 2004.

35. Een dergelijke correctie zou wellicht ook moeten worden gemaakt voor de inzet in contractonderzoek omdat de inzet in contractonderzoek vaak niet besteed kan worden aan fundamenteel wetenschappelijk onderzoek. 
Tabel 8.9 geeft per faculteit de ontwikkeling van de onderzoeksout/onderzoeksinput ratio voor wetenschappelijke publicaties, verbijzonderd naar refereed en non-refereed en vaktechnische publicaties. De tabellen laten zien dat de onderzoeksperformance van de verschillende faculteiten volgens deze maatstaven aanzienlijk uiteenloopt. Ook wordt duidelijk dat er aanzienlijke accentverschillen zijn in het soort publicaties waarop de faculteiten zich richten. De FdR en FdG hebben in het algemeen de beste performance op het gebied van wetenschappelijke publicaties. De FdCW scoort daarentegen laag op wetenschappelijke publicaties maar hoog op vakpublicaties.

Tabel 8.9

Aantal wetenschappelijke publicaties per mensjaar equivalent, 1999-2003

\begin{tabular}{|c|c|c|c|c|c|}
\hline Faculteit & 1999 & 2000 & 2001 & 2002 & 2003 \\
\hline \multicolumn{6}{|c|}{ Wetenschappelijke publicaties (refereed) } \\
\hline FdAW & 1,7 & 2,3 & 1,8 & 1,5 & 2,0 \\
\hline $\mathrm{FdCW}$ &. & & & 1,0 & 2,1 \\
\hline FdEW & 2,1 & 2,1 & 2,7 & 1,8 & 1,6 \\
\hline FdG & 3,6 & 3,7 & 3,4 & 3,6 & 4,5 \\
\hline FdGW & 3,5 & 3,2 & 3,5 & 2,9 & 2,9 \\
\hline $\mathrm{FdP}$ & 5,3 & 3,0 & 3,0 & 3,1 & 2,9 \\
\hline FdR & 6,9 & 7,0 & 7,2 & 6,1 & $*$ \\
\hline Totaal & 3,4 & 3,4 & 3,3 & 3,1 & 3,8 \\
\hline \multicolumn{6}{|c|}{ Wetenschappelijke publicaties (non-refereed) } \\
\hline & 1999 & 2000 & 2001 & 2002 & 2003 \\
\hline FdAW & . & . & . & 1,3 & 1,3 \\
\hline $\mathrm{FdCW}$ & . & . & . & 4,1 & 3,3 \\
\hline FdEW & 2,5 & 2,5 & 2,7 & 2,7 & 2,4 \\
\hline $\mathrm{FdG}$ & 0,1 & 0,1 & 0,1 & 0,0 & 0,1 \\
\hline FdGW & 0,0 & 0,0 & 0,1 & 0,0 & 0,0 \\
\hline $\mathrm{FdP}$ & 0,1 & 0,1 & 0,0 & 0,1 & 0,0 \\
\hline $\mathrm{FdR}$ & 6,1 & 7,9 & 7,1 & 4,6 & $*$ \\
\hline Totaal & 1,0 & 1,0 & 0,9 & 0,9 & 1,0 \\
\hline \multicolumn{6}{|c|}{ Vakpublicaties } \\
\hline & 1999 & 2000 & 2001 & 2002 & 2003 \\
\hline FdAW & 1,1 & 1,7 & 1,3 & 0,4 & 0,5 \\
\hline $\mathrm{FdCW}$ & 2,0 & 4,1 & 2,6 & 4,1 & 3,7 \\
\hline FdEW & 1,0 & 0,5 & 0,4 & 0,3 & 0,5 \\
\hline $\mathrm{FdG}$ & 1,0 & 0,9 & 0,8 & 0,8 & 0,9 \\
\hline FdGW & 1,9 & 1,7 & 1,6 & 1,3 & 1,1 \\
\hline $\mathrm{FdP}$ & 0,8 & 1,4 & 1,0 & 1,0 & 1,0 \\
\hline $\mathrm{FdR}$ & 2,7 & 2,1 & 2,4 & 4,2 & $*$ \\
\hline Totaal & 1,3 & 1,2 & 1,1 & 1,1 & 1,2 \\
\hline
\end{tabular}

Nadeel van deze maatstaf is dat er geen rekening wordt gehouden met het tijdsverloop tussen de afronding van onderzoek en de uiteindelijke publicaties. Met name bij wetenschappelijke publicaties gaat er vaak wel twee jaar overheen voordat een artikel daadwerkelijk gepubliceerd wordt. Als de onderzoekscapaciteit wordt uitgebreid is het effect daarvan op publicaties pas een paar jaar later zichtbaar. De performance-indicator daalt dan omdat het aantal publicaties gelijk blijft terwijl de onderzoekscapa- 
citeit is vergoot. Om dit effect tegen te gaan kan de onderzoeksoutput wellicht beter worden gerelateerd aan de onderzoekscapaciteit van een aantal jaren eerder. Om de juiste vertraging te bepalen zijn echter nadere analyses nodig.

Omdat er tussen tijdschriften, waarin artikelen worden gerefereed, grote kwaliteitsverschillen zijn is het wenselijk om de publicaties in deze tijdschriften nog verder te classificeren. Om deze reden hebben de FdEWB, FdG, FdGW en FdP een eigen classificatiesysteem voor wetenschappelijke publicaties. Een eigen classificatiesysteem makkt het mogelijk om binnen een faculteit de prestaties van capaciteitsgroepen en individuele medewerkers te vergelijken, maar kan meestal niet worden gebruikt om de onderzoeksoutput van een faculteit te vergelijken met de onderzoeksoutput van onderzoeksgroepen op hetzelfde gebied aan andere universiteiten. Voor dit laatste zou een landelijk classificatiesysteem per vakgebied nodig zijn, bijvoorbeeld op basis van impactscores van tijdschriften.

Voor de FdEWB zijn de outputindicatoren op basis van het eigen classificatiesysteem beschikbaar per capaciteitsgroep. In dit systeem zijn alle voor de faculteit relevante tijdschriften onderverdeeld in 4 categorieën, A tot en met D, waarbij een A-publicatie het hoogst gewaardeerd wordt. Een boekbijdrage geldt als C-publicatie en een volledig boek kan zowel als A, B of C worden gewaardeerd. Een dissertatie geldt als B-publicatie. De onderzoeksoutput per capaciteitsgroep wordt berekend op basis van een punten systeem. Een A-publicatie krijgt Io punten, een B publicatie 6 punten, een C-publicatie 2 punten en een D-publicatie o punten.

\section{Tabel 8.10}

Onderzoeksperformance per mensjaar equivalent van de capaciteitsgroepen van de FdEWB (AAP punten), 2001 en 2004

$\begin{array}{lcc} & & 2004 \\ & & \\ & & \\ \text { Algemene economie } & 6,1 \\ \text { Acountancy \& Informatiemanagement } & 6,1 & 0,8 \\ \text { Financiering } & 3,1 & 4,8 \\ \text { Marketing } & 4,2 & 5,2 \\ \text { Organsiatie \&Strategie } & 2,7 & 4,2 \\ \text { Kwantitatieve Economie } & 4,2 & 4,5 \\ \text { Onderwijs \& Ontwikkeling } & 6,9 & 1,2 \\ \text { Merit* } & 0,2 & 0,6 \\ \text { ROA* } & 2,2 \\ \text { Totaal FdEWB } & 1,1 & 3,4 \\ \text { * De cijfers voor deze onderzoeksinstituten zijn niet gecorrigeerd voor de werktijd die besteed wordt aan } \\ \text { Contractonderzoek } & 3,4 & \\ \text { Bron: FdEWB (Miso) } & & \end{array}$

In tabel 8.Io worden de onderzoeksprestaties in termen van deze AAP-punten gerelateerd aan de onderzoeksinput per mje. Uit de tabel blijkt dat de verschillen in onderzoeksperformance tussen capaciteitsgroepen binnen een faculteit aanzienlijk kunnen zijn. 


\section{Promoties}

Ook het aantal dissertaties per onderzoeksgroep is een indicator voor de onderzoeksoutput. Het aantal promoties is voor alle faculteiten bekend (zie Tabel 8.II) en kan eveneens worden gerelateerd aan de onderzoeksinput. Het ligt voor de hand om de onderzoeksinput daarbij te beperken tot dat deel dat zich met de begeleiding van promovendi kan bezig houden: hoogleraren, UHD's en UD's. Wel geldt ook hier dat er rekening moet worden gehouden met een vertraging tussen inspanning en performance, omdat een promotietraject meerdere jaren beslaat. Een uitbreiding van de 'begeleidingscapaciteit' voor promovendi heeft immers pas na minimaal 4 jaar effect. Een mogelijke performance-indicator is derhalve het aantal dissertaties in een bepaald jaar ten opzichte van het aantal fte hoogleraren, UHD's en UD's van 4 jaar eerder. De laatste kolom van tabel 8.II geeft een overzicht van deze indicator voor de verschillende faculteiten. Gemiddeld genomen is er jaarlijks bijna één dissertatie per $4 \mathrm{fte}$ begeleidingsinzet. De verschillen tussen de faculteiten zijn echter aanzienlijk. Bij de rechtenfaculteit is er I dissertatie per 7,6 fte begeleidingscapaciteit, tegenover I dissertatie per 2,7 fte begeleidingscapaciteit bij de geneeskundefaculteit.

Tabel 8.11

Aantal dissertaties per faculteit en promotieperformance, 1999 en 2003

$\begin{array}{lccc}\text { Faculteit } & 1999 & 2003 & \begin{array}{c}\text { Promotie- } \\ \text { Performance* }\end{array} \\ \text { FdAW } & & & \\ \text { FdCW } & 4 & 5 & 0,28 \\ \text { FdEW } & 2 & 5 & 0,16 \\ \text { FdG } & 14 & 17 & 0,18 \\ \text { FdGW } & 55 & 67 & 0,36 \\ \text { FdP } & 13 & 21 & 0,21 \\ \text { FdR } & 3 & 5 & 0,18 \\ \text { Total UM } & 4 & 10 & 0,13 \\ & 95 & 130 & 0,24\end{array}$

* het aantal dissertaties in 2003 ten opzichte van het totaal aantal fte hoogleraren, UHD's en UD's voor 1999

\section{Verwerven tweede en derde geldstroommiddelen}

De kwaliteit van onderzoek wordt ten slotte ook wel gemeten door naar het externe onderzoeksinkomen te kijken. Het idee hierachter is dat externe geldstromen de marktwaarde van het onderzoek weerspiegelen en daarom kunnen worden gezien als een proxy voor output. ${ }^{36}$ Voor de UM zouden de verkregen tweede en derde geldstroom middelen als een indicator van de onderzoeksperformance kunnen worden gehanteerd. De verkregen tweedegeldstroom middelen geven een indicatie van de wetenschappelijke kwaliteit van het onderzoek, terwijl de derdegeldstroom middelen een indicatie geven van de maatschappelijke relevantie van het onderzoek.

36. M. Abobott en H. Doucouliagos, "Research Output of Australian Universities", Education Economics, vol. I2, no. 3, December 2004 . 
Tabel 8.I2 geeft een overzicht van de omzet in tweede en derde geldstroom per mje wp per faculteit. Uit de tabel blijkt dat met name de faculteiten Gezondheidswetenschappen en Cultuurwetenschappen relatief veel tweede- of derdegeldstroommiddelen verwerven.

Tabel 8.12

Omzet tweede en derde geldstroom per mje WP ( $x \in 1.000), 1999$ en 2002

$\begin{array}{lrr} & & \\ \text { Faculteit } & 1999 & 2002 \\ \text { FdAW } & & 18,7 \\ \text { FdCW } & 0,6 & 47,7 \\ \text { FdEWB* } & 12,3 & 1,7 \\ \text { FdG } & 2,7 & 35,0 \\ \text { FdGW } & 35,3 & 64,5 \\ \text { FdP } & 48,3 & 20,8 \\ \text { FdR } & 7,3 & 19,2 \\ \text { Totaal UM } & 7,6 & 33,4 \\ \text { * alleen tweedegeldstroom middelen } & 26,7 & \end{array}$

\section{Peer reviews}

Naast bovenstaande kwantitatieve performanceindicatoren kan de kwaliteit van een onderzoeksgroep ook worden bepaald op basis van 'peer reviews'. In Nederland is er een visitatiesysteem voor het wetenschappelijk onderzoek. Een voordeel van dit systeem is dat de performance van een onderzoeksgroep direct kan worden vergeleken met de performance van gelijke onderzoeksgroepen aan andere faculteiten. Een nadeel is dat de visitaties slechts één keer in de zes jaar plaats vindt. Aan de UM heeft in 1999 een onderzoeksvisitatie bij de FdP plaatsgevonden en in 2002 bij de FdEWB en de FdR.

\subsection{Samenvatting: Indicatoren voor de HRM-portfolio}

In dit hoofdstuk zijn we ingegaan op mogelijke performance indicatoren voor het onderwijs en het onderzoek aan de UM. Voor het onderwijs zijn er indicatoren voor het interne en externe rendement van het onderwijs, de kwaliteit van het onderwijsproces en de wervingskracht van de UM. Voor het onderzoek hebben de indicatoren betrekking op zowel het wetenschappelijk onderzoek als de maatschappelijke dienstverlening. Tabel 8.I3 geeft een overzicht van de indicatoren die in de HRM portfolio worden opgenomen.

Voor het interne rendement kijken we zowel naar het propedeuse rendement na twee jaar als het studierendement na zes jaar. De indicatoren voor het externe rendement hebben betrekking op de kans op betaald werk, het bruto uurloon en de carrière mogelijkheden van de baan anderhalf jaar na afstuderen. Voor de kwaliteit van het onderwijs zijn nog geen gegevens beschikbaar die tussen faculteiten vergelijkbaar zijn. Op basis van de onderwijsevaluatie gegevens van de FdEWB is een indicator voor de kwaliteit van het onderwijs per capaciteitsgroep aan de FdEWB ontwikkeld. Een 
dergelijke indicator kan op termijn ook voor de docentenkwaliteit worden ontwikkeld. Voorwaarde is wel dat er een betrouwbare koppeling kan worden gemaakt tussen de evaluatiegegevens en de tutorgegevens. Het zou goed zijn als deze indicatoren in de toekomst voor alle faculteiten berekend zou kunnen worden. Indicatoren voor de wervingskracht van het onderwijs aan de UM zijn de ontwikkeling van het aantal eerstejaarsstudenten en de procentuele instroom van regulier buitenlandse studenten.

Voor het wetenschappelijk onderzoek nemen we het jaarlijkse aantal wetenschappelijke publicaties per mensjaar WP en het jaarlijkse aantal dissertaties per fte begeleidingscapaciteit als indicatoren op. Het aantal vakpublicaties per mensjaar WP en de omzet in tweede en derde geldstroom per mensjaar WP zijn indicatoren voor de maatschappelijke waarde van het onderzoek aan de UM.

\section{Tabel 8.13}

Indicatoren met betrekking tot onderwijs- en onderzoeksperformance

\begin{tabular}{|c|c|c|c|c|c|c|c|}
\hline & FdAW & $\mathrm{FdCW}$ & FdEWB & $\mathrm{FdG}$ & FdGW & $\mathrm{FdP}$ & $\mathrm{FdR}$ \\
\hline \multicolumn{8}{|l|}{ Propedeuserendement } \\
\hline $\begin{array}{l}\text { \% studenten na } 2 \text { jaar propedeuse behaald } \\
\text { (cohort 01/02) } \\
\text { Studierendement }\end{array}$ & - & 51 & 58 & 95 & 85 & 59 & 48 \\
\hline $\begin{array}{l}\text { \% studenten dat na } 6 \text { jaar is afgestudeerd } \\
\text { (cohort } 97 / 98 \text { ) } \\
\text { Extern rendement } \\
\text { Indicator betaald werk }\end{array}$ & - & 35 & 46 & 87 & 52 & 45 & 40 \\
\hline - UM & - & - & 7,0 & 8,5 & 8,2 & 6,1 & 6,9 \\
\hline - Landelijk & - & - & 7,6 & 9,0 & 8,0 & 6,4 & 7,4 \\
\hline Indicator bruto uurloon & & & & & & & \\
\hline - UM & - & - & 8,1 & 9,8 & 7,9 & 6,4 & 7,3 \\
\hline - Landelijk & - & - & 8,3 & 9,6 & 7,6 & 7,0 & 8,1 \\
\hline Indicator carrière mogelijkheden & & & & & & & \\
\hline$-U M$ & - & - & 7,7 & 8,3 & 6,9 & 7,1 & 7,6 \\
\hline - Landelijk & - & - & 7,6 & 8,2 & 7,0 & 6,4 & 7,4 \\
\hline Kwaliteit onderwijsproces & & & & & & & \\
\hline Kwaliteit onderwijs & * & * & * & * & * & * & * \\
\hline $\begin{array}{l}\text { Kwaliteit docenten } \\
\text { Wervingskracht } \\
\text { Instroom studenten }\end{array}$ & * & * & * & * & * & * & * \\
\hline $\begin{array}{l}\text { Index ontwikkeling instroom eerstejaars } \\
2004 / 2005(1999=100)\end{array}$ & 92 & 444 & 94 & 157 & 78 & 117 & 73 \\
\hline $\begin{array}{l}\text { \% Instroom buitenlandse studenten } \\
\text { Wetenschappelijk onderzoek }\end{array}$ & & 51 & 48 & 4 & 10 & 41 & 14 \\
\hline $\begin{array}{l}\text { Wetenschappelijke publicaties (refereed) per } \\
\text { mensjaar WP } 2003\end{array}$ & 2,0 & 2,1 & 1,6 & 4,5 & 2,9 & 2,9 & - \\
\hline $\begin{array}{l}\text { Jaarlijkse aantal dissertaties per fte } \\
\text { begeleidingscapaciteit } \\
\text { Maatschappelijke dienstverlening }\end{array}$ & 0,28 & 0,16 & 0,18 & 0,36 & 0,21 & 0,18 & 0,13 \\
\hline Vakpublicaties per mensjaar WP & 0,5 & 3,7 & 0,5 & 0,9 & 1,1 & 1,0 & - \\
\hline $\begin{array}{l}\text { Omzet tweede en derde geldstroom per } \\
\text { mensjaar WP }\end{array}$ & 18,7 & 47,7 & 1,7 & 35,0 & 64,5 & 20,8 & 19,2 \\
\hline
\end{tabular}




\section{Bijlage I Eerste invulling HRM Portfolio UM}

Tabel B.1

Indicatoren HRM Portfolio Universiteit Maastricht, 1 april 2005

$\begin{array}{cccc}\text { UM } & \text { UM } & \text { UM } \\ & \text { Capaciteits- } & \text { Onder- } & \text { Totaal } \\ & \text { groepen } & \text { steunende } & \\ & & \text { diensten }\end{array}$

\section{Beschikbare Human Resources}

Verhouding WP en OBP:

$\%$ WP'ers

Academische functies:

$\%$ medewerkers in salarisschaal 10 of hoger

\section{Ervaringsconcentratie:}

$\%$ medewerkers meer dan 10 jaar in dienst

Vernieuwing:

$\%$ medewerkers korter dan 2 jaar in dienst

Omloopsnelheid personeel:

\section{Indicator omloopsnelheid 2003/04}

Ontwikkeling 2000-2004

Interne rekrutering WP:

$\%$ intern opgevulde vacatures voor

Opwaartse mobiliteit OBP:

\% OBP'ers dat in periode 1999-2004 minstens 1 schaal is gestegen

\section{Zekerheid:}

$\%$ medewerkers met een vast contract

Parttimers:

$\%$ medewerkers in deeltijd

Vergrijzing:

$\%$ medewerkers ouder dan 55

Emancipatie:

$\%$ vrouwelijke medewerkers

Internationalisering:

$\%$ medewerkers met niet-Nederlandse nationaliteit

Competenties

- rapportcijfer vakspecifieke kennis 
Tabel B.1 (vervolg)

Indicatoren HRM Portfolio Universiteit Maastricht, 1 april 2005

$\begin{array}{cccc}\text { UM } & \text { UM } & \text { UM } \\ \text { Capaciteits- } & \text { Onder- } & \text { Total } \\ \text { groepen } & \text { steunende } & \\ & & \text { diensten }\end{array}$

\section{HRM beleid \\ Managementstijl}

Consistent uitdragen van visie en strategie $\quad 3,5$

Draagvlak creëren voor beslissingen

Waardering uiten voor successen in inspanningen

Nee kunnen zeggen

- Werving en selectie

Moeilijk vervulbare vacatures:

$\%$ organisatie-eenheden met moeilijk vervulbare vacatures

\section{Arbeidsvoorwaardenbeleid}

Gratificaties:

$\%$ medewerkers dat een gratificatie ontvangt

Keuzemodel Arbeidsvoorwaarden UM:

$\%$ medewerkers dat hiervan gebruik maakt

\section{Personeelsontwikkelingsbeleid}

Functioneringsgesprekken:

$\%$ organisatie-eenheden met functioneringsgesprekken voor alle

medewerkers

coaching:

$\%$ organisatie-eenheden met coaching voor alle medewerkers

Persoonlijke ontwikkelingsplannen:

$\%$ organisatie-eenheden met POPs voor alle

Internationale uitwisseling:

$\%$ medewerkers dat is uitgewisseld

Internationale congressen:

$\%$ organisatie-eenheden waar alle wetenschappelijk medewerkers deelnemen aan internationale congressen

\section{Scholing van medewerkers}

Cursusparticipatie:

$\%$ medewerkers dat cursussen volgt

3. Prestatiemaatstaven

Tevredenheid medewerkers

$\%$ medewerkers dat tevreden is met het werk

\section{Ziekteverzuim}

$\%$ ziekteverzuim 2004

a Deze cijfers hebben betrekking op respectievelijk het WP en OBP

- onvoldoende waarnemingen; . niet van toepassing

* wordt op dit moment nog niet verzameld

Bron: ROA/SAP informatiesysteem UM/Enquête onder beherend bazen 2005 
Tabel B.2

Indicatoren HRM Portfolio Faculteit der Algemene Wetenschappen, 1 april 2005

WP

OBP

Totaal

1. Beschikbare Human Resources

Verhouding WP en OBP:

$\%$ WP'ers

Academische functies:

$\%$ medewerkers in salarisschaal 10 of hoger

Ervaringsconcentratie

$\%$ medewerkers meer dan 10 jaar in dienst

Vernieuwing:

$\%$ medewerkers korter dan 2 jaar in dienst

Omloopsnelheid personeel:

Indicator omloopsnelheid 2003/04

Ontwikkeling 2000-2004

Interne rekrutering WP:

$\%$ intern opgevulde vacatures voor

- UD

- UHD

- Hoogleraar

Opwaartse mobiliteit OBP:

\% OBP'ers dat in periode 1999-2004 minstens 1 schaal is gestegen

Mobiliteit OBP naar andere UM organisaties

Zekerheid:

$\%$ medewerkers met een vast contract

$\%$ medewerkers in deeltijd

Vergrijzing:

$\%$ medewerkers ouder dan 55

Emancipatie:

$\%$ vrouwelijke medewerkers

Internationalisering:

$\%$ medewerkers met niet-Nederlandse nationaliteit

Competenties:

- rapportcijfer vakspecifieke kennis

- rapportcijfer IT vaardigheden

- rapportcijfer beheersing Engels

\section{HRM beleid}

\section{Werving en selectie}

Moeilijk vervulbare vacatures:

$\%$ organisatie-eenheden met moeilijk vervulbare vacatures

\section{Arbeidsvoorwaardenbeleid}

Gratificaties:

$\%$ medewerkers dat een gratificatie ontvangt

Keuzemodel Arbeidsvoorwaarden UM:

$\%$ medewerkers dat hiervan gebruik maakt

\section{Personeelsontwikkelingsbeleid}

Functioneringsgesprekken:

$\%$ organisatie-eenheden met functioneringsgesprekken voor alle medewerkers

Coaching:

$\%$ organisatie-eenheden met coaching voor alle medewerkers

Persoonlijke ontwikkelingsplannen:

$\%$ organisatie-eenheden met POPs voor alle medewerkers 
Tabel B.2 (vervolg)

Indicatoren HRM Portfolio Faculteit der Algemene Wetenschappen, 1 april 2005

\begin{tabular}{|c|c|c|c|}
\hline & WP & $\mathrm{OBP}$ & Totaal \\
\hline \multicolumn{4}{|l|}{ Internationale uitwisseling: } \\
\hline$\%$ medewerkers dat is uitgewisseld & * & * & * \\
\hline \multicolumn{4}{|l|}{ Internationale congressen: } \\
\hline \multicolumn{4}{|l|}{$\%$ organisatie-eenheden waar alle medewerkers deelnemen aan } \\
\hline \multicolumn{4}{|l|}{$\begin{array}{l}\text { Scholing van medewerkers } \\
\text { Curusnarticinatip. }\end{array}$} \\
\hline$\%$ medewerkers dat cursussen volgt & - & - & - \\
\hline \multicolumn{4}{|l|}{$\begin{array}{l}\text { 3. Prestatiemaatstaven } \\
\text { Tevredenheid medewerkers }\end{array}$} \\
\hline$\%$ medewerkers dat tevreden is met het werk & * & * & * \\
\hline \multicolumn{4}{|l|}{ Ziekteverzuim } \\
\hline \% ziekteverzuim 2004 & & & 2,8 \\
\hline \multicolumn{4}{|l|}{ Instroom studenten } \\
\hline Index ontwikkeling instroom eerstejaars 2004 (index 1999=100) & & & 92 \\
\hline$\%$ instroom buitenlandse studenten & & & - \\
\hline \multicolumn{4}{|l|}{ Interne rendement } \\
\hline \multicolumn{4}{|l|}{ Propadeuserendement } \\
\hline $\begin{array}{l}\text { \% studenten dat na } 2 \text { jaar propadeuse heeft gehaald } \\
\text { (cohort 1997/98) }\end{array}$ & & & 76 \\
\hline \multicolumn{4}{|l|}{ Studierendement } \\
\hline \multicolumn{4}{|l|}{$\begin{array}{l}\text { \% studenten dat na } 6 \text { jaar is afgestudeerd } \\
\text { (cohort 1997/98) }\end{array}$} \\
\hline \multicolumn{4}{|l|}{ Kwaliteit onderwijsproces } \\
\hline Kwaliteit onderwijs & & & * \\
\hline Kwaliteit docenten & & & * \\
\hline \multicolumn{4}{|l|}{ Externe rendement } \\
\hline \multicolumn{4}{|l|}{ Indicator betaald werk } \\
\hline- UM & & & - \\
\hline - Landelijk & & & - \\
\hline \multicolumn{4}{|l|}{ Indicator bruto uurloon } \\
\hline- UM & & & - \\
\hline - Landelijk & & & - \\
\hline \multicolumn{4}{|l|}{ Indicator carrièremogelijkheden } \\
\hline- UM & & & - \\
\hline - Landelijk & & & - \\
\hline \multicolumn{4}{|l|}{ Wetenschappelijk onderzoek } \\
\hline Wetenschappelijke publicaties & & & 2,0 \\
\hline \multicolumn{4}{|l|}{ Publicaties in 'refereed' tijdschriften per mensjaar WP 2003} \\
\hline \multicolumn{4}{|l|}{ Dissertaties } \\
\hline Aantal dissertaties per fte WP 2003 & & & 0,28 \\
\hline \multicolumn{4}{|l|}{ Maatschappelijke dienstverlening } \\
\hline Vakpublicaties per mensjaar WP 2003 & & & 0,5 \\
\hline Omzet tweede en derde geldstroom per mensjaar WP 2002 & & & 18.700 \\
\hline
\end{tabular}


Tabel B.3

Indicatoren HRM Portfolio Faculteit der Cultuurwetenschappen, 1 april 2005

\section{Beschikbare Human Resources}

Verhouding WP en OBP:

$\%$ WP'ers

Academische functies:

$\%$ medewerkers in salarisschaal 10 of hoger

Ervaringsconcentratie:

$\%$ medewerkers meer dan 10 jaar in dienst

Vernieuwing:

$\%$ medewerkers korter dan 2 jaar in dienst

Omloopsnelheid personeel:

Indicator omloopsnelheid 2003/04

$22 \quad 37$

Ontwikkeling 2000-2004

dalend

Interne rekrutering WP:

$\%$ intern opgevulde vacatures voor

- UD

- UHD

- Hoogleraar

Opwaartse mobiliteit OBP:

\% OBP'ers dat in periode 1999-2004 minstens 1 schaal is gestegen

Mobiliteit OBP naar andere UM organisaties

Zekerheid:

$\%$ medewerkers met een vast contract

Parttimers:

$\%$ medewerkers in deeltijd

Vergrijzing:

$\%$ medewerkers ouder dan 55

Emancipatie:

$\%$ vrouwelijke medewerkers

Internationalisering:

$\%$ medewerkers met niet-Nederlandse nationaliteit

Competenties:

- rapportcijfer vakspecifieke kennis

- rapportcijfer IT vaardigheden

- rapportcijfer beheersing Engels

\section{HRM beleid}

\section{Werving en selectie}

Moeilijk vervulbare vacatures:

organisatie-eenheden met moeilijk vervulbare vacatures

\section{Arbeidsvoorwaardenbeleid}

Gratificaties:

$\%$ medewerkers dat een gratificatie ontvangt

\section{Personeelsontwikkelingsbeleid}

Functioneringsgesprekken:

$\%$ organisatie-eenheden met functioneringsgesprekken voor alle medewerkers Coaching:

$\%$ organisatie-eenheden met coaching voor alle medewerkers 
Tabel B.3 (vervolg)

Indicatoren HRM Portfolio Faculteit der Cultuurwetenschappen, 1 april 2005

WP

Persoonlijke ontwikkelingsplannen:

$\%$ organisatie-eenheden met POPs voor alle medewerkers

Internationale uitwisseling:

$\%$ medewerkers dat is uitgewisseld

Internationale congressen:

$\%$ organisatie-eenheden waar alle medewerkers deelnemen aan internationale

congressen

\section{Scholing van medewerkers}

Cursusparticipatie:

$\%$ medewerkers dat cursussen volgt

\section{Prestatiemaatstaven}

\section{Tevredenheid medewerkers}

$\%$ medewerkers dat tevreden is met het werk

\section{Ziekteverzuim}

$\%$ ziekteverzuim 2004

Instroom studenten

Index ontwikkeling instroom eerstejaars 2004 (index 1999=100)

$\%$ instroom buitenlandse studenten

\section{Interne rendement}

Propadeuserendement

\% studenten dat na 2 jaar propadeuse heeft gehaald (cohort 1997/98)

Studierendement

$\%$ studenten dat na 6 jaar is afgestudeerd

(cohort 1997/98)

Kwaliteit onderwijsproces

Kwaliteit onderwijs

Kwaliteit docenten

Externe rendement

Indicator betaald werk

- UM

- Landelijk

Indicator bruto uurloon

- UM

- Landelijk

Indicator carrièremogelijkheden

- UM

- Landelijk

Wetenschappelijk onderzoek

Wetenschappelijke publicaties

Publicaties in 'refereed'tijdschriften per mensjaar WP 2003

Dissertaties

Aantal dissertaties per fte WP 2003

Maatschappelijke dienstverlening

Vakpublicaties per mensjaar WP 2003

Omzet tweede en derde geldstroom per mensjaar WP 2002

- onvoldoende waarnemingen

. niet van toepassing

* wordt op dit moment nog niet verzameld

Bron: ROA/SAP informatiesysteem UM/Enquête onder beherend bazen 2005 
Tabel B.4

Indicatoren HRM Portfolio Faculteit der Economische Wetenschappen en Bedrijfskunde, 1 april 2005

\begin{tabular}{|c|c|c|c|}
\hline & WP & OBP & Totaal \\
\hline \multicolumn{4}{|l|}{ 1. Beschikbare Human Resources } \\
\hline \multicolumn{4}{|l|}{ Verhouding WP en OBP: } \\
\hline$\%$ WP'ers & . & . & 71 \\
\hline \multicolumn{4}{|l|}{ Academische functies: } \\
\hline$\%$ medewerkers in salarisschaal 10 of hoger & 100 & 26 & 79 \\
\hline \multicolumn{4}{|l|}{ Ervaringsconcentratie: } \\
\hline$\%$ medewerkers meer dan 10 jaar in dienst & 32 & 33 & 32 \\
\hline \multicolumn{4}{|l|}{ Vernieuwing: } \\
\hline$\%$ medewerkers korter dan 2 jaar in dienst & 48 & 33 & 44 \\
\hline \multicolumn{4}{|l|}{ Omloopsnelheid personeel: } \\
\hline Indicator omloopsnelheid 2003/04 & 26 & 18 & \\
\hline Ontwikkeling 2000-2004 & dalend & gelijk & \\
\hline \multicolumn{4}{|l|}{ Interne rekrutering WP: } \\
\hline \multicolumn{4}{|l|}{$\%$ intern opgevulde vacatures voor } \\
\hline UD & 48 & . & 48 \\
\hline UHD & 93 & . & 93 \\
\hline Hoogleraar & 50 & . & 50 \\
\hline \multicolumn{4}{|l|}{ Opwaartse mobiliteit OBP: } \\
\hline \% OBP'ers dat in periode $1999-2004$ minstens 1 schaal is gestegen & . & 59 & 59 \\
\hline Mobiliteit OBP naar andere UM organisaties & . & 14 & 14 \\
\hline \multicolumn{4}{|l|}{ Zekerheid: } \\
\hline$\%$ medewerkers met een vast contract & 49 & 82 & 59 \\
\hline \multicolumn{4}{|l|}{ Parttimers: } \\
\hline$\%$ medewerkers in deeltijd & 35 & 53 & 40 \\
\hline \multicolumn{4}{|l|}{ Vergrijzing: } \\
\hline$\%$ medewerkers ouder dan 55 & 8 & 8 & 8 \\
\hline \multicolumn{4}{|l|}{ Emancipatie: } \\
\hline$\%$ vrouwelijke medewerkers & 22 & 75 & 37 \\
\hline \multicolumn{4}{|l|}{ Internationalisering: } \\
\hline$\%$ medewerkers met niet-Nederlandse nationaliteit & 36 & 8 & 28 \\
\hline \multicolumn{4}{|l|}{ Competenties: } \\
\hline - rapportcijfer vakspecifieke kennis & - & - & - \\
\hline - rapportcijfer IT vaardigheden & - & - & - \\
\hline - rapportcijfer beheersing Engels & - & - & - \\
\hline \multicolumn{4}{|l|}{$\begin{array}{l}\text { 2. HRM beleid } \\
\text { Werving en selectie } \\
\text { Moeilijk vervulbare vacatures: }\end{array}$} \\
\hline$\%$ organisatie-eenheden met moeilijk vervulbare vacatures & - & - & - \\
\hline \multicolumn{4}{|l|}{$\begin{array}{l}\text { Arbeidsvoorwaardenbeleid } \\
\text { Gratificaties: }\end{array}$} \\
\hline$\%$ medewerkers dat een gratificatie ontvangt & 16 & 33 & 21 \\
\hline \multicolumn{4}{|l|}{ Keuzemodel Arbeidsvoorwaarden UM: } \\
\hline$\%$ medewerkers dat hiervan gebruik maakt & * & * & * \\
\hline \multicolumn{4}{|l|}{ Personeelsontwikkelingsbeleid } \\
\hline \multicolumn{4}{|l|}{ Functioneringsgesprekken: } \\
\hline $\begin{array}{l}\% \text { organisatie-eenheden met functioneringsgesprekken voor alle medewerkers } \\
\text { Coaching: }\end{array}$ & - & - & - \\
\hline$\%$ organisatie-eenheden met coaching voor alle medewerkers & - & - & - \\
\hline
\end{tabular}


Tabel B.4 (vervolg)

Indicatoren HRM Portfolio Faculteit der Economische Wetenschappen en Bedrijfskunde, 1 april 2005

\begin{tabular}{|c|c|c|c|}
\hline & WP & $\mathrm{OBP}$ & Totaal \\
\hline \multicolumn{4}{|l|}{ Persoonlijke ontwikkelingsplannen: } \\
\hline$\%$ organisatie-eenheden met POPs voor alle medewerkers & - & - & - \\
\hline \multicolumn{4}{|l|}{ Internationale uitwisseling: } \\
\hline$\%$ medewerkers dat is uitgewisseld & * & * & * \\
\hline \multicolumn{4}{|l|}{ Internationale congressen: } \\
\hline$\%$ organisatie-eenheden waar alle medewerkers deelnemen aan internationale congressen & - & - & - \\
\hline \multicolumn{4}{|l|}{ Scholing van medewerkers } \\
\hline \multicolumn{4}{|l|}{ Cursusparticipatie: } \\
\hline$\%$ medewerkers dat cursussen volgt & - & - & - \\
\hline \multicolumn{4}{|l|}{$\begin{array}{l}\text { 3. Prestatiemaatstaven } \\
\text { Tevredenheid medewerkers }\end{array}$} \\
\hline$\%$ medewerkers dat tevreden is met het werk & * & * & * \\
\hline \multicolumn{4}{|l|}{ Ziekteverzuim } \\
\hline \% ziekteverzuim 2004 & & & 2,2 \\
\hline \multicolumn{4}{|l|}{ Instroom studenten } \\
\hline Index ontwikkeling instroom eerstejaars 2004 (index 1999=100) & & & 94 \\
\hline \% instroom buitenlandse studenten & & & 48 \\
\hline \multicolumn{4}{|l|}{ Interne rendement } \\
\hline \% studenten dat na 2 jaar propadeuse heeft gehaald (cohort 1997/98) & & & 61 \\
\hline \multicolumn{4}{|l|}{ Studierendement } \\
\hline $\begin{array}{l}\text { \% studenten dat na } 6 \text { jaar is afgestudeerd } \\
\text { (cohort 1997/98) }\end{array}$ & & & 46 \\
\hline \multicolumn{4}{|l|}{ Kwaliteit onderwijsproces } \\
\hline Kwaliteit onderwijs & & & * \\
\hline Kwaliteit docenten & & & * \\
\hline \multicolumn{4}{|l|}{ Externe rendement } \\
\hline \multicolumn{4}{|l|}{ Indicator betaald werk } \\
\hline- UM & & & 7,0 \\
\hline - Landelijk & & & 7,6 \\
\hline \multicolumn{4}{|l|}{ Indicator bruto uurloon } \\
\hline- UM & & & 8,1 \\
\hline - Landelijk & & & 8,3 \\
\hline \multicolumn{4}{|l|}{ Indicator carrièremogelijkheden } \\
\hline- UM & & & 7,7 \\
\hline - Landelijk & & & 7,6 \\
\hline \multicolumn{4}{|l|}{ Wetenschappelijk onderzoek } \\
\hline Wetenschappelijke publicaties & & & 1,6 \\
\hline \multicolumn{4}{|l|}{ Publicaties in 'refereed' tijdschriften per mensjaar WP 2003} \\
\hline \multicolumn{4}{|l|}{ Dissertaties } \\
\hline Aantal dissertaties per fte WP 2003 & & & 0,18 \\
\hline \multicolumn{4}{|l|}{ Maatschappelijke dienstverlening } \\
\hline Vakpublicaties per mensjaar WP 2003 & & & 0,5 \\
\hline Omzet tweede en derde geldstroom per mensjaar WP $2002^{* *}$ & & & 1.700 \\
\hline
\end{tabular}


Tabel B.5

Indicatoren HRM Portfolio Faculteit der Geneeskunde, 1 april 2005

WP

\section{Beschikbare Human Resources}

Verhouding WP en OBP:

$\%$ WP'ers

Academische functies:

$\%$ medewerkers in salarisschaal 10 of hoger

Ervaringsconcentratie:

$\%$ medewerkers meer dan 10 jaar in dienst

31

Vernieuwing:

$\%$ medewerkers korter dan 2 jaar in dienst

52

eid personeel:

Indicator omloopsnelheid 2003/04

31

21

Ontwikkeling 2000-2004

Interne rekrutering WP.

$\%$ intern opgevulde vacatures voor

- UD

- UHD

- Hoogleraar

Opwaartse mobiliteit OBP:

\% OBP'ers dat in periode 1999-2004 minstens 1 schaal is gestegen

Mobiliteit OBP naar andere UM organisaties

Zekerheid:

$\%$ medewerkers met een vast contract

$\%$ medewerkers in deeltijd

$\%$ medewerkers ouder dan 55

Emancipatie:

$\%$ vrouwelijke medewerkers

\%

$\%$ medewerkers met niet-Nederlandse nationaliteit

Competenties:

- rapportcijfer vakspecifieke kennis

- rapportcijfer IT vaardigheden

- rapportcijfer beheersing Engels

\section{HRM beleid}

\section{Werving en selectie}

Moeilijk vervulbare vacatures:

$\%$ organisatie-eenheden met moeilijk vervulbare vacatures

\section{Arbeidsvoorwaardenbeleid}

Gratificaties:

$\%$ medewerkers dat een gratificatie ontvangt

Keuzemodel Arbeidsvoorwaarden UM:

$\%$ medewerkers dat hiervan gebruik maakt

\section{Personeelsontwikkelingsbeleid}

Functioneringsgesprekken:

$\%$ organisatie-eenheden met functioneringsgesprekken voor alle medewerkers

Coaching:

$\%$ organisatie-eenheden met coaching voor alle medewerkers 
Tabel B.5 (vervolg)

Indicatoren HRM Portfolio Faculteit der Geneeskunde, 1 april 2005

Persoonlijke ontwikkelingsplannen:

organisatie-eenheden met POPs voor alle medewerkers

Internationale uitwisseling:

$\%$ medewerkers dat is uitgewisseld

Internationale congressen:

$\%$ organisatie-eenheden waar alle medewerkers deelnemen aan internationale congressen

Scholing van medewerkers

Cursusparticipatie:

$\%$ medewerkers dat cursussen volgt

\section{Prestatiemaatstaven \\ Tevredenheid medewerkers}

$\%$ medewerkers dat tevreden is met het werk

Ziekteverzuim

\% ziekteverzuim 2004

Instroom studenten

$\%$ instroom buitenlandse studenten

Interne rendement

Propadeuserendement

$\%$ studenten dat na 2 jaar propadeuse heeft gehaald

(cohort 1997/98)

Studierendement

$\%$ studenten dat na 6 jaar is afgestudeerd

(cohort 1997/98)

Kwaliteit onderwijsproces

Kwaliteit onderwijs

Kwaliteit docenten

\section{Externe rendement}

Indicator betaald werk

- UM

- Landelijk

Indicator bruto uurloon

- UM

- Landelijk

Indicator carrièremogelijkheden

- UM

- Landelijk

Wetenschappelijk onderzoek

Wetenschappelijke publicaties

Publicaties in 'refereed' tijdschriften per mensjaar WP 2003

Dissertaties

Aantal dissertaties per fte WP 2003

Maatschappelijke dienstverlening

Vakpublicaties per mensjaar WP 2003

Omzet tweede en derde geldstroom per mensjaar WP 2002

- onvoldoende waarnemingen

. niet van toepassing

* wordt op dit moment nog niet verzameld

Bron: ROA/SAP informatiesysteem UM/Enquête onder beherend bazen 2005 
Tabel B.6

Indicatoren HRM Portfolio Faculteit der Gezondheidswetenschappen, 1 april 2005

WP

OBP

Totaal

1. Beschikbare Human Resources

Verhouding WP en OBP:

\%WP'ers

Academische functies:

$\%$ medewerkers in salarisschaal 10 of hoger

18

73

Ervaringsconcentratie:

$\%$ medewerkers meer dan 10 jaar in dienst

26

42

$\%$ medewerkers korter dan 2 jaar in dienst

60

41

Omloopsnelheid personeel:

Indicator omloopsnelheid 2003/04

37

24

Ontwikkeling 2000-2004

gelijk dalend

Interne rekrutering WP:

$\%$ intern opgevulde vacatures voor

- UD

43

43

- UHD

69

- Hoogleraar

46

69

Opwaartse mobiliteit OBP:

\% OBP'ers dat in periode 1999-2004 minstens 1 schaal is gestegen

Mobiliteit OBP naar andere UM organisaties

Zekerheid:

$\%$ medewerkers met een vast contract

Parttimers:

$\%$ medewerkers in deeltijd

Vergrijzing:

$\%$ medewerkers ouder dan 55

Emancipatie:

$\%$ vrouwelijke medewerkers

Internationalisering:

$\%$ medewerkers met niet-Nederlandse nationaliteit

Competenties:

- rapportcijfer vakspecifieke kennis

- rapportcijfer IT vaardigheden

- rapportcijfer beheersing Engels

\section{HRM beleid}

\section{Werving en selectie}

Moeilijk vervulbare vacatures:

$\%$ organisatie-eenheden met moeilijk vervulbare vacatures

Arbeidsvoorwaardenbeleid

Gratificaties:

$\%$ medewerkers dat een gratificatie ontvangt

5

17

Keuzemodel Arbeidsvoorwaarden UM:

$\%$ medewerkers dat hiervan gebruik maakt

Personeelsontwikkelingsbeleid

Functioneringsgesprekken:

$\%$ organisatie-eenheden met functioneringsgesprekken voor alle medewerkers

Coaching:

$\%$ organisatie-eenheden met coaching voor alle medewerkers

Persoonlijke ontwikkelingsplannen:

$\%$ organisatie-eenheden met POPs voor alle medewerkers 


\section{Tabel B.6 (vervolg)}

Indicatoren HRM Portfolio Faculteit der Gezondheidswetenschappen, 1 april 2005

\begin{tabular}{|c|c|c|c|}
\hline & WP & OBP & Totaal \\
\hline \multicolumn{4}{|l|}{ Internationale uitwisseling: } \\
\hline $\begin{array}{l}\text { \% medewerkers dat is uitgewisseld } \\
\text { Internationale congressen: }\end{array}$ & * & * & * \\
\hline$\%$ organisatie-eenheden waar alle medewerkers deelnemen aan internationale congressen & - & - & - \\
\hline \multicolumn{4}{|l|}{ Scholing van medewerkers } \\
\hline \multicolumn{4}{|l|}{ Cursusparticipatie: } \\
\hline$\%$ medewerkers dat cursussen volgt & - & - & - \\
\hline \multicolumn{4}{|l|}{$\begin{array}{l}\text { 3. Prestatiemaatstaven } \\
\text { Tevredenheid medewerkers }\end{array}$} \\
\hline$\%$ medewerkers dat tevreden is met het werk & * & * & * \\
\hline \multicolumn{4}{|l|}{ Ziekteverzuim } \\
\hline \% ziekteverzuim 2004 & & & 4,0 \\
\hline \multicolumn{4}{|l|}{ Instroom studenten } \\
\hline Index ontwikkeling instroom eerstejaars 2004 (index 1999=100) & & & 78 \\
\hline$\%$ instroom buitenlandse studenten & & & 10 \\
\hline \multicolumn{4}{|l|}{ Interne rendement } \\
\hline \multicolumn{4}{|l|}{ Propadeuserendement } \\
\hline \multicolumn{4}{|l|}{ (cohort 1997/98) } \\
\hline \multicolumn{4}{|l|}{ Studierendement } \\
\hline \multicolumn{4}{|l|}{ (cohort 1997/98) } \\
\hline \multicolumn{4}{|l|}{ Kwaliteit onderwijsproces } \\
\hline Kwaliteit onderwijs & & & * \\
\hline Kwaliteit docenten & & & * \\
\hline \multicolumn{4}{|l|}{ Externe rendement } \\
\hline \multicolumn{4}{|l|}{ Indicator betaald werk } \\
\hline- UM & & & 8,2 \\
\hline - Landelijk & & & 8,0 \\
\hline \multicolumn{4}{|l|}{ Indicator bruto uurloon } \\
\hline- UM & & & 7,9 \\
\hline - Landelijk & & & 7,6 \\
\hline \multicolumn{4}{|l|}{ Indicator carrièremogelijkheden } \\
\hline- UM & & & 6,9 \\
\hline - Landelijk & & & 7,0 \\
\hline \multicolumn{4}{|l|}{ Wetenschappelijk onderzoek } \\
\hline Wetenschappelijke publicaties & & & 2,9 \\
\hline \multicolumn{4}{|l|}{ Publicaties in 'refereed' tijdschriften per mensjaar WP 2003} \\
\hline \multicolumn{4}{|l|}{ Dissertaties } \\
\hline Aantal dissertaties per fte WP 2003 & & & 0,21 \\
\hline \multicolumn{4}{|l|}{ Maatschappelijke dienstverlening } \\
\hline Vakpublicaties per mensjaar WP 2003 & & & 1,1 \\
\hline Omzet tweede en derde geldstroom per mensjaar WP 2002 & & & 64.500 \\
\hline
\end{tabular}


Tabel B.7

Indicatoren HRM Portfolio Faculteit der Psychologie, 1 april 2005

WP

OBP

Totaal

1. Beschikbare Human Resources

Verhouding WP en OBP:

$\%$ WP'ers

Academische functies:

$\%$ medewerkers in salarisschaal 10 of hoger

100

22

75

Ervaringsconcentratie:

$\%$ medewerkers meer dan 10 jaar in dienst

14

29

19

Vernieuwing:

$\%$ medewerkers korter dan 2 jaar in dienst

56

55

Omloopsnelheid personeel:

Indicator omloopsnelheid 2003/04

21

27

Ontwikkeling 2000-2004

dalen

stijgend

Interne rekrutering WP:

$\%$ intern opgevulde vacatures voor

- UD

- UHD

- Hoogleraar

50

Opwaartse mobiliteit OBP:

\% OBP'ers dat in periode 1999-2004 minstens 1 schaal is gestegen

Mobiliteit OBP naar andere UM organisaties

Zekerheid:

$\%$ medewerkers met een vast contract

36

46

Parttimers:

$\%$ medewerkers in deeltijd

18

67

28

Vergrijzing:

$\%$ medewerkers ouder dan 55

6

6

Emancipatie:

$\%$ vrouwelijke medewerkers

47

67

53

Internationalisering:

$\%$ medewerkers met niet-Nederlandse nationaliteit

22

10

18

Competenties:

- rapportciifer vakspecifieke kennis

- rapportcijfer IT vaardigheden

- rapportcijfer beheersing Engels

\section{HRM beleid}

\section{Werving en selectie}

Moeilijk vervulbare vacatures:

$\%$ organisatie-eenheden met moeilijk vervulbare vacatures

Arbeidsvoorwaardenbeleid

Gratificaties:

$\%$ medewerkers dat een gratificatie ontvangt

92

82

89

Keuzemodel Arbeidsvoorwaarden UM:

$\%$ medewerkers dat hiervan gebruik maakt

Personeelsontwikkelingsbeleid

Functioneringsgesprekken:

$\%$ organisatie-eenheden met functioneringsgesprekken voor alle medewerkers

Coaching:

$\%$ organisatie-eenheden met coaching voor alle medewerkers

Persoonlijke ontwikkelingsplannen:

$\%$ organisatie-eenheden met POPs voor alle medewerkers 
Tabel B.7 (vervolg)

Indicatoren HRM Portfolio Faculteit der Psychologie, 1 april 2005

\begin{tabular}{|c|c|c|c|}
\hline & WP & $\mathrm{OBP}$ & Totaal \\
\hline \multicolumn{4}{|l|}{ Internationale uitwisseling: } \\
\hline$\%$ medewerkers dat is uitgewisseld & * & * & * \\
\hline \multicolumn{4}{|l|}{$\%$ medewerkers dat deelneemt } \\
\hline \multicolumn{4}{|l|}{ Internationale congressen: } \\
\hline $\begin{array}{l}\% \text { organisatie-eenheden waar alle medewerkers deelnemen aan internationale } \\
\text { congressen }\end{array}$ & - & - & - \\
\hline \multicolumn{4}{|l|}{ Scholing van medewerkers } \\
\hline \multicolumn{4}{|l|}{ Cursusparticipatie: } \\
\hline$\%$ medewerkers dat cursussen volgt & - & - & - \\
\hline \multicolumn{4}{|l|}{ 3. Prestatiemaatstaven } \\
\hline \multicolumn{4}{|l|}{ Tevredenheid medewerkers } \\
\hline$\%$ medewerkers dat tevreden is met het werk & * & * & * \\
\hline \multicolumn{4}{|l|}{ Ziekteverzuim } \\
\hline \% ziekteverzuim 2004 & & & 2,9 \\
\hline \multicolumn{4}{|l|}{ Instroom studenten } \\
\hline Index ontwikkeling instroom eerstejaars 2004 (index 1999=100) & & & 117 \\
\hline \% instroom buitenlandse studenten & & & 41 \\
\hline \multicolumn{4}{|l|}{ Interne rendement } \\
\hline \multicolumn{4}{|l|}{ Propadeuserendement } \\
\hline \multicolumn{4}{|l|}{ (cohort 1997/98) } \\
\hline \multicolumn{4}{|l|}{ Studierendement } \\
\hline \multicolumn{4}{|l|}{$\begin{array}{l}\text { \% studenten dat na } 6 \text { jaar is afgestudeerd } \\
\text { (cohort 1997/98) }\end{array}$} \\
\hline \multicolumn{4}{|l|}{ Kwaliteit onderwijsproces } \\
\hline Kwaliteit onderwijs & & & * \\
\hline Kwaliteit docenten & & & * \\
\hline \multicolumn{4}{|l|}{ Externe rendement } \\
\hline \multicolumn{4}{|l|}{ Indicator betaald werk } \\
\hline- UM & & & 6,1 \\
\hline - Landelijk & & & 6,4 \\
\hline \multicolumn{4}{|l|}{ Indicator bruto uurloon } \\
\hline- UM & & & 6,4 \\
\hline & & & 7,0 \\
\hline \multicolumn{4}{|l|}{ Indicator carrièremogelijkheden } \\
\hline- UM & & & 7,1 \\
\hline - Landelijk & & & 6,4 \\
\hline \multicolumn{4}{|l|}{ Wetenschappelijk onderzoek } \\
\hline Wetenschappelijke publicaties & & & 2,9 \\
\hline \multicolumn{4}{|l|}{ Publicaties in 'refereed' tijdschriften per mensjaar WP 2003} \\
\hline \multicolumn{4}{|l|}{ Dissertaties } \\
\hline Aantal dissertaties per fte WP 2003 & & & 0,18 \\
\hline \multicolumn{4}{|l|}{ Maatschappelijke dienstverlening } \\
\hline Vakpublicaties per mensjaar WP 2003 & & & 1,0 \\
\hline Omzet tweede en derde geldstroom per mensjaar WP 2002 & & & 20.800 \\
\hline
\end{tabular}


Tabel B.8

Indicatoren HRM Portfolio Faculteit der Rechten, 1 april 2005

\section{Beschikbare Human Resources}

Verhouding WP en OBP:

\%WP'ers

Academische functies:

$\%$ medewerkers in salarisschaal 10 of hoger

rvaringsconcentratie:

$\%$ medewerkers meer dan 10 jaar in dienst

Omloopsnelheid personeel:

Indicator omloopsnelheid 2003/04

Ontwikkeling 2000-2004

dalend

Interne rekrutering WP

$\%$ intern opgevulde vacatures voor

- UD

- UHD

- Hoogleraar

Opwaartse mobiliteit OBP.

\% OBP'ers dat in periode 1999-2004 minstens 1 schaal is gestegen

Mobiliteit OBP naar andere UM organisaties

Zekerheid:

$\%$ medewerkers met een vast contract

Parttimers:

$\%$ medewerkers in deeltijd

Vergrijzing:

$\%$ medewerkers ouder dan 55

Emancipatie:

$\%$ vrouwelijke medewerkers

Internationalisering:

$\%$ medewerkers met niet-Nederlandse nationaliteit

Competenties:

- rapportcijfer vakspecifieke kennis

- rapportcijfer IT vaardigheden

- rapportcijfer beheersing Engels

\section{HRM beleid}

\section{Werving en selectie}

Moeilijk vervulbare vacatures:

$\%$ organisatie-eenheden met moeilijk vervulbare vacatures

\section{Arbeidsvoorwaardenbeleid}

Gratificaties:

$\%$ medewerkers dat een gratificatie ontvangt

Keuzemodel Arbeidsvoorwaarden UM:

$\%$ medewerkers dat hiervan gebruik maakt

- Personeelsontwikkelingsbeleid

Functioneringsgesprekken:

$\%$ organisatie-eenheden met functioneringsgesprekken voor alle medewerkers

Coaching:

$\%$ organisatie-eenheden met coaching voor alle medewerkers

Persoonlijke ontwikkelingsplannen:

$\%$ organisatie-eenheden met POPs voor alle medewerkers 
Tabel B.8 (vervolg)

Indicatoren HRM Portfolio Faculteit der Rechten, 1 april 2005

Internationale uitwisseling:

$\%$ medewerkers dat is uitgewisseld

Internationale congressen:

$\%$ organisatie-eenheden waar alle medewerkers deelnemen aan internationale congressen

Scholing van medewerkers

Cursusparticipatie:

$\%$ medewerkers dat cursussen volgt

\section{Prestatiemaatstaven}

Tevredenheid medewerkers

$\%$ medewerkers dat tevreden is met het werk

Ziekteverzuim

\% ziekteverzuim 2004

Instroom studenten

Index ontwikkeling instroom eerstejaars 2004 (index 1999=100)

$\%$ instroom buitenlandse studenten

Interne rendement

Propadeuserendement

$\%$ studenten dat na 2 jaar propadeuse heeft gehaald

Studierendement

\% studenten dat na 6 jaar is afgestudeerd (cohort 1997/98)

Kwaliteit onderwijsproces

Kwaliteit onderwijs

Kwaliteit docenten

\section{Externe rendement}

Indicator betaald werk

- UM

- Landelijk

Indicator bruto uurloon

- UM

- Landelijk

Indicator carrièremogelijkheden

- UM

- Landelijk

Wetenschappelijk onderzoek

Wetenschappelijke publicaties

Publicaties in 'refereed' tijdschriften per mensjaar WP (cijfer 2002)

Dissertaties

Aantal dissertaties per fte WP 2003

Maatschappelijke dienstverlening

Vakpublicaties per mensjaar WP (cijfer 2002)

Omzet tweede en derde geldstroom per mensjaar WP 2002

- onvoldoende waarnemingen; . niet van toepassing

* wordt op dit moment nog niet verzameld

Bron: ROA/SAP informatiesysteem UM/Enquête onder beherend bazen 2005 
Tabel B.9

Indicatoren HRM Portfolio Bureau Universiteit, 1 april 2005

\section{Beschikbare Human Resources}

Verhouding WP en OBP:

$\%$ WP'ers

Academische functies:

$\%$ medewerkers in salarisschaal 10 of hoger

rvaringsconcentratie:

$\%$ medewerkers meer dan 10 jaar in dienst

Vernieuwing:

$\%$ medewerkers korter dan 2 jaar in dienst

opsnelheid personeel:

Indicator omloopsnelheid 2003/04

Ontwikkeling 2000-2004

dalend

Opwaartse mobiliteit:

\% OBP'ers dat in periode 1999-2004 minstens 1 schaal is gestegen

Mobiliteit OBP naar andere UM organisaties

Zekerheid:

$\%$ medewerkers met een vast contract

$\%$ medewerkers in deeltijd

Vergrijzing:

$\%$ medewerkers ouder dan 55

Emancipatie:

$\%$ vrouwelijke medewerkers

nternationalisering:

$\%$ medewerkers met niet-Nederlandse nationaliteit

Competenties:

- rapportciifer vakspecifieke kennis

- rapportcijfer IT vaardigheden

- rapportcijfer beheersing Engels

\section{HRM beleid}

\section{Werving en selectie}

Moeilijk vervulbare vacatures:

$\%$ organisatie-eenheden met moeilijk vervulbare vacatures

\section{Arbeidsvoorwaardenbeleid}

Gratificaties:

$\%$ medewerkers dat een gratificatie ontvangt

Keuzemodel Arbeidsvoorwaarden UM:

$\%$ medewerkers dat hiervan gebruik maakt

Personeelsontwikkelingsbeleid

Functioneringsgesprekken:

$\%$ organisatie-eenheden met functioneringsgesprekken voor alle medewerkers

Coaching:

$\%$ organisatie-eenheden met coaching voor alle medewerkers

Persoonlijke ontwikkelingsplannen:

$\%$ organisatie-eenheden met POPs voor alle medewerkers

Internationale uitwisseling:

$\%$ medewerkers dat is uitgewisseld

Internationale congressen:

$\%$ organisatie-eenheden waar alle medewerkers deelnemen aan internationale congressen

Scholing van medewerkers

Cursusparticipatie:

$\%$ medewerkers dat cursussen volgt 
Tabel B.9 (vervolg)

Indicatoren HRM Portfolio Bureau Universiteit, 1 april 2005

\section{Prestatiemaatstaven}

Tevredenheid medewerkers

$\%$ medewerkers dat tevreden is met het werk

Ziekteverzuim

\% ziekteverzuim 2004

- onvoldoende waarnemingen

* wordt op dit moment nog niet verzameld

1) Inclusief verplaatsing van functies naar servicecentra

Bron: ROA/SAP informatiesysteem UM 
Tabel B.10

Indicatoren HRM Portfolio Servicecentra (totaal), 1 april 2005

1. Beschikbare Human Resources

Verhouding WP en OBP:

$\%$ WP'ers

Academische functies:

$\%$ medewerkers in salarisschaal 10 of hoger

Ervaringsconcentratie:

$\%$ medewerkers meer dan 10 jaar in dienst

Vernieuwing:

$\%$ medewerkers korter dan 2 jaar in dienst

Omloopsnelheid personeel:

Indicator omloopsnelheid 2003/04

Ontwikkeling 2000-2004

Opwaartse mobiliteit:

\% OBP'ers dat in periode 1999-2004 minstens 1 schaal is gestegen

Mobiliteit OBP naar andere UM organisaties

ekerheid:

$\%$ medewerkers met een vast contract

Parttimers:

$\%$ medewerkers in deeltijd

$\%$ medewerkers ouder dan 55

Emancipatie:

$\%$ vrouwelijke medewerkers

$\%$ medewerkers met niet-Nederlandse nationaliteit

Competenties:

- rapportciifer vakspecifieke kennis

- rapportcijfer IT vaardigheden

- rapportcijfer beheersing Engels

\section{HRM beleid}

\section{Werving en selectie}

Moeilijk vervulbare vacatures:

$\%$ organisatie-eenheden met moeilijk vervulbare vacatures

\section{Arbeidsvoorwaardenbeleid}

Gratificaties:

$\%$ medewerkers dat een gratificatie ontvangt

$\%$ medewerkers dat hiervan gebruik maakt

Personeelsontwikkelingsbeleid

Functioneringsgesprekken:

$\%$ organisatie-eenheden met functioneringsgesprekken voor alle medewerkers

Coaching:

$\%$ organisatie-eenheden met coaching voor alle medewerkers

Persoonlijke ontwikkelingsplannen:

$\%$ organisatie-eenheden met POPs voor alle medewerkers

Internationale uitwisseling:

$\%$ medewerkers dat is uitgewisseld

Internationale congressen:

$\%$ organisatie-eenheden waar alle medewerkers deelnemen aan internationale congressen 
Tabel B.10 (vervolg)

Indicatoren HRM Portfolio Servicecentra (totaal), 1 april 2005

\section{Scholing van medewerkers}

Cursusparticipatie:

$\%$ medewerkers dat cursussen volgt

3. Prestatiemaatstaven

Tevredenheid medewerkers

$\%$ medewerkers dat tevreden is met het werk

\section{Ziekteverzuim}

$\%$ ziekteverzuim 2004

- onvoldoende waarnemingen

. niet van toepassing

* wordt op dit moment nog niet verzameld

** is berekend voor afzonderlijke servicecentra

Bron: ROA/SAP informatiesysteem UM/Enquête onder beherend bazen 2005 
Tabel B.11

Indicatoren HRM Portfolio Administratief servicecentrum, 1 april 2005

\section{Beschikbare Human Resources}

Verhouding WP en OBP:

\%WP'ers

Academische functies:

$\%$ medewerkers in salarisschaal 10 of hoger

Ervaringsconcentratie:

$\%$ medewerkers meer dan 10 jaar in dienst

Vernieuwing:

$\%$ medewerkers korter dan 2 jaar in dienst

Omloopsnelheid personeel:

Indicator omloopsnelheid 2003/04a

Ontwikkeling 2000-2004a

dalend

\% OBP'ers dat in periode 1999-2004 minstens 1 schaal is gestegen

Zekerheid:

$\%$ medewerkers met een vast contract

$\%$ medewerkers in deeltijd

$\%$ medewerkers ouder dan 55

$\%$ vrouwelijke medewerkers

Internationalisering:

$\%$ medewerkers met niet-Nederlandse nationaliteit

Competenties:

- rapportciifer vakspecifieke kennis

- rapportcijfer IT vaardigheden

- rapportcijfer beheersing Engels

\section{HRM beleid \\ Werving en selectie}

Moeilijk vervulbare vacatures:

$\%$ organisatie-eenheden met moeilijk vervulbare vacatures

\section{Arbeidsvoorwaardenbeleid}

Gratificaties:

$\%$ medewerkers dat een gratificatie ontvangt

Keuzemodel Arbeidsvoorwaarden UM:

$\%$ medewerkers dat hiervan gebruik maakt

Personeelsontwikkelingsbeleid

Functioneringsgesprekken:

$\%$ organisatie-eenheden met functioneringsgesprekken voor alle medewerkers

Coaching:

$\%$ organisatie-eenheden met coaching voor alle medewerkers

Persoonlijke ontwikkelingsplannen:

$\%$ organisatie-eenheden met POPs voor alle medewerkers

Internationale uitwisseling:

$\%$ medewerkers dat is uitgewisseld

Internationale congressen:

$\%$ organisatie-eenheden waar alle medewerkers deelnemen aan internationale congressen

Scholing van medewerkers

Cursusparticipatie:

$\%$ medewerkers dat cursussen volgt 
Tabel B.11 (vervolg)

Indicatoren HRM Portfolio Administratief servicecentrum, 1 april 2005

\section{Prestatiemaatstaven}

Tevredenheid medewerkers

$\%$ medewerkers dat tevreden is met het werk

\section{Ziekteverzuim}

$\%$ ziekteverzuim 2004

- onvoldoende waarnemingen

- niet van toepassing

* wordt op dit moment nog niet verzameld

Bron: ROA/SAP informatiesysteem UM/Enquête onder beherend bazen 2005 
Tabel B.12

Indicatoren HRM Portfolio Facilitaire dienst, 1 april 2005

\section{Beschikbare Human Resources}

Verhouding WP en OBP:

$\%$ WP'ers

Academische functies:

$\%$ medewerkers in salarisschaal 10 of hoger

Ervaringsconcentratie:

$\%$ medewerkers meer dan 10 jaar in dienst

Vernieuwing:

$\%$ medewerkers korter dan 2 jaar in dienst

Omloopsnelheid personeel:

Indicator omloopsnelheid 2003/04

Ontwikkeling 2000-2004

dalend

waartse mobiliteit:

Zekerheid:

$\%$ medewerkers met een vast contract

Parttimers:

$\%$ medewerkers in deeltijd

Vergrijzing:

$\%$ medewerkers ouder dan 55

$\%$ vrouwelijke medewerkers

nternationalisering:

$\%$ medewerkers met niet-Nederlandse nationaliteit

Competenties:

- rapportciifer vakspecifieke kennis

- rapportcijfer IT vaardigheden

- rapportcijfer beheersing Engels

\section{HRM beleid}

\section{Werving en selectie}

Moeilijk vervulbare vacatures:

$\%$ organisatie-eenheden met moeilijk vervulbare vacatures

\section{Arbeidsvoorwaardenbeleid}

Gratificaties:

$\%$ medewerkers dat een gratificatie ontvangt

$\%$ medewerkers dat hiervan gebruik maakt

Personeelsontwikkelingsbeleid

Functioneringsgesprekken:

$\%$ organisatie-eenheden met functioneringsgesprekken voor alle medewerkers

Coaching:

$\%$ organisatie-eenheden met coaching voor alle medewerkers

Persoonlijke ontwikkelingsplannen:

$\%$ organisatie-eenheden met POPs voor alle medewerkers

Internationale uitwisseling:

$\%$ medewerkers dat is uitgewisseld

Internationale congressen:

$\%$ organisatie-eenheden waar alle medewerkers deelnemen aan internationale congressen

Scholing van medewerkers

Cursusparticipatie:

$\%$ medewerkers dat cursussen volgt 
Tabel B.12 (vervolg)

Indicatoren HRM Portfolio Facilitaire dienst, 1 april 2005

\section{Prestatiemaatstaven}

Tevredenheid medewerkers

$\%$ medewerkers dat tevreden is met het werk

\section{Ziekteverzuim}

\% ziekteverzuim 2004

- onvoldoende waarnemingen

. niet van toepassing

* wordt op dit moment nog niet verzameld

Bron: ROA/SAP informatiesysteem UM/Enquête onder beherend bazen 2005 
Tabel B.13

Indicatoren HRM Portfolio ICT servicecentrum, 1 april 2005

\section{Beschikbare Human Resources}

Verhouding WP en OBP:

$\%$ WP'ers

Academische functies:

$\%$ medewerkers in salarisschaal 10 of hoger

Ervaringsconcentratie:

$\%$ medewerkers meer dan 10 jaar in dienst

vernieuwing:

$\%$ medewerkers korter dan 2 jaar in dienst

Omloopsnelheid personeel:

Indicator omloopsnelheid 2003/04

Ontwikkeling 2000-2004 ${ }^{\mathrm{a}}$

dalend

Opwaartse mobiliteit:

\% OBP'ers dat in periode 1999-2004 minstens 1 schaal is gestegen

Zekerheid:

$\%$ medewerkers met een vast contract

Parttimers:

$\%$ medewerkers in deeltijd

Vergrijzing:

$\%$ medewerkers ouder dan 55

Emancipatie:

$\%$ vrouwelijke medewerkers

Internationalisering:

$\%$ medewerkers met niet-Nederlandse nationaliteit

Competenties:

- rapportcijfer vakspecifieke kennis

- rapportcijfer IT vaardigheden

- rapportcijfer beheersing Engels

\section{HRM beleid}

\section{Werving en selectie}

Moeilijk vervulbare vacatures:

$\%$ organisatie-eenheden met moeilijk vervulbare vacatures

\section{Arbeidsvoorwaardenbeleid}

Gratificaties:

$\%$ medewerkers dat een gratificatie ontvangt

Keuzemodel Arbeidsvoorwaarden UM:

$\%$ medewerkers dat hiervan gebruik maakt

Personeelsontwikkelingsbeleid

Functioneringsgesprekken:

$\%$ organisatie-eenheden met functioneringsgesprekken voor alle medewerkers

Coaching:

$\%$ organisatie-eenheden met coaching voor alle medewerkers

Persoonlijke ontwikkelingsplannen:

$\%$ organisatie-eenheden met POPs voor alle medewerkers

Internationale uitwisseling:

$\%$ medewerkers dat is uitgewisseld

Internationale congressen:

$\%$ organisatie-eenheden waar alle medewerkers deelnemen aan internationale congressen 
Tabel B.13 (vervolg)

Indicatoren HRM Portfolio ICT servicecentrum, 1 april 2005

\section{Scholing van medewerkers}

Cursusparticipatie:

$\%$ medewerkers dat cursussen volgt

\section{Prestatiemaatstaven}

Tevredenheid medewerkers

$\%$ medewerkers dat tevreden is met het werk

Ziekteverzuim

\% ziekteverzuim 2004

- onvoldoende waarnemingen

. niet van toepassing

* wordt op dit moment nog niet verzameld

Bron: ROA/SAP informatiesysteem UM/Enquête onder beherend bazen 2005 
Tabel B.14

Indicatoren HRM Portfolio Studenten servicecentrum, 1 april 2005

1. Beschikbare Human Resources

Verhouding WP en OBP:

$\%$ WP'ers

Academische functies:

$\%$ medewerkers in salarisschaal 10 of hoger

varingsconcentratie:

$\%$ medewerkers meer dan 10 jaar in dienst

Vernieuwing:

$\%$ medewerkers korter dan 2 jaar in dienst

oopsnelheid personeel:

Indicator omloopsnelheid 2003/04

Ontwikkeling 2000-2004

gelijk

Opwaartse mobiliteit:

\% OBP'ers dat in periode 1999-2004 minstens 1 schaal is gestegen $\quad 78$

Zekerheid:

$\%$ medewerkers met een vast contract

Parttimers:

$\%$ medewerkers in deeltijd

Vergrijzing:

$\%$ medewerkers ouder dan 55

Emancipatie:

$\%$ vrouwelijke medewerkers

Internationalisering:

$\%$ medewerkers met niet-Nederlandse nationaliteit

Competenties:

- rapportcijfer vakspecifieke kennis

- rapportcijfer IT vaardigheden

- rapportcijfer beheersing Engels

\section{HRM beleid}

\section{Werving en selectie}

Moeilijk vervulbare vacatures:

$\%$ organisatie-eenheden met moeilijk vervulbare vacatures

\section{Arbeidsvoorwaardenbeleid}

Gratificaties:

$\%$ medewerkers dat een gratificatie ontvangt

Keuzemodel Arbeidsvoorwaarden UM:

$\%$ medewerkers dat hiervan gebruik maakt

Personeelsontwikkelingsbeleid

Functioneringsgesprekken:

$\%$ organisatie-eenheden met functioneringsgesprekken voor alle medewerkers

Coaching:

$\%$ organisatie-eenheden met coaching voor alle medewerkers

Persoonlijke ontwikkelingsplannen:

$\%$ organisatie-eenheden met POPs voor alle medewerkers

Internationale uitwisseling:

$\%$ medewerkers dat is uitgewisseld

Internationale congressen:

$\%$ organisatie-eenheden waar alle medewerkers deelnemen aan internationale congressen

\section{scholing van medewerkers}

Cursusparticipatie:

$\%$ medewerkers dat cursussen volgt 
Tabel B.14 (vervolg)

Indicatoren HRM Portfolio Studenten servicecentrum, 1 april 2005

3. Prestatiemaatstaven

Tevredenheid medewerkers

$\%$ medewerkers dat tevreden is met het werk

Ziekteverzuim

$\%$ ziekteverzuim 2004

- onvoldoende waarnemingen

. niet van toepassing

* wordt op dit moment nog niet verzameld

Bron: ROA/SAP informatiesysteem UM/Enquête onder beherend bazen 2005 
Tabel B.15

Indicatoren HRM Portfolio Universiteitsbibliotheek, 1 april 2005

\section{Beschikbare Human Resources}

Verhouding WP en OBP:

$\%$ WP'ers

Academische functies:

$\%$ medewerkers in salarisschaal 10 of hoger

Ervaringsconcentratie:

$\%$ medewerkers meer dan 10 jaar in dienst

Vernieuwing:

$\%$ medewerkers korter dan 2 jaar in dienst

Omloopsnelheid personeel:

Indicator omloopsnelheid 2003/04

Ontwikkeling 2000-2004

Opwaartse mobiliteit:

\% OBP'ers dat in periode 1999-2004 minstens 1 schaal is gestegen

Zekerheid:

$\%$ medewerkers met een vast contract

Parttimers:

$\%$ medewerkers in deeltijd

Vergrijzing:

$\%$ medewerkers ouder dan 55

Emancipatie:

$\%$ vrouwelijke medewerkers

internationalisering:

$\%$ medewerkers met niet-Nederlandse nationaliteit

Competenties:

- rapportcijfer vakspecifieke kennis

- rapportcijfer IT vaardigheden

- rapportcijfer beheersing Engels

\section{HRM beleid}

\section{Werving en selectie}

Moeilijk vervulbare vacatures:

$\%$ organisatie-eenheden met moeilijk vervulbare vacatures

\section{Arbeidsvoorwaardenbeleid}

Gratificaties:

$\%$ medewerkers dat een gratificatie ontvangt

Keuzemodel Arbeidsvoorwaarden UM:

$\%$ medewerkers dat hiervan gebruik maakt

Personeelsontwikkelingsbeleid

Functioneringsgesprekken:

$\%$ organisatie-eenheden met functioneringsgesprekken voor alle medewerkers

Coaching:

$\%$ organisatie-eenheden met coaching voor alle medewerkers

Persoonlijke ontwikkelingsplannen:

$\%$ organisatie-eenheden met POPs voor alle medewerkers

Internationale uitwisseling:

$\%$ medewerkers dat is uitgewisseld

Internationale congressen:

$\%$ organisatie-eenheden waar alle medewerkers deelnemen aan internationale congressen

Scholing van medewerkers

Cursusparticipatie:

$\%$ medewerkers dat cursussen volgt 
Tabel B.15 (vervolg)

Indicatoren HRM Portfolio Universiteitsbibliotheek, 1 april 2005

\section{Prestatiemaatstaven}

Tevredenheid medewerkers

$\%$ medewerkers dat tevreden is met het werk

\section{Ziekteverzuim}

\% ziekteverzuim 2004

- onvoldoende waarnemingen

. niet van toepassing

* wordt op dit moment nog niet verzameld

Bron: ROA/SAP informatiesysteem UM/Enquête onder beherend bazen 2005 


\section{Bijlage II Vragenlijsten enquêtes onder de beherend bazen van de capaciteitsgroepen en de ondersteunende diensten}

\section{A. VRAGENLIJST CAPACITEITSGROEPEN}

Algemeen

I. Hoeveel medewerkers zijn er momenteel werkzaam in de (cap)groep waaraan u leiding geeft? (inclusief tijdelijk personeel)

Capgroep

Sommige faculteiten spreken van departementen; indien u leiding geeft aan een sectie binnen een bepaalde capgroep, verzoeken wij u telkens uit te gaan van deze sectie.

- $\quad$ wetenschappelijk personeel ... (aantal personen)

- waarvan $\mathrm{AIO} /$ promovendus ...

- OBP ...

2. Hoeveel medewerkers zijn lid van een onderzoekschool?

... (aantal personen)

\section{Functies}

3. Hoe zou u de functies van Universitair Docenten (UD's), uitgaande van de huidige personeelssamenstelling van uw capgroep, graag willen invullen?

Capgroep

Sommige faculteiten spreken van departementen; indien u leiding geeft aan een sectie binnen een bepaalde capgroep, verzoeken wij $u$ telkens uit te gaan van deze sectie.

Onderwijstaken minimaal maximaal

Onderzoekstaken

$\ldots \%$

$\ldots \%$

Bestuurlijke taken

$\ldots \%$

$\ldots \%$

$\ldots \%$

...\% 


\section{Selectie van nieuw wetenschappelijk personeel}

Via een aantal vragen willen we bij $\mathrm{u}$ aftasten hoe $\mathrm{u}$ bij het aantrekken van een nieuwe Universitair docent onderwijskwaliteiten afweegt tegen onderzoekskwaliteiten.

Om hiervan een goed totaalbeeld te krijgen is het belangrijk dat $\mathrm{u}$ iedere keer een kandidaat kiest, ook al zou u liever geen van beide kandidaten willen aannemen.

4. Wanneer er bij een vacature voor een Universitair Docent (UD) twee kandidaten zijn, die op alle andere punten geheel gelijkwaardig zijn, aan welke geeft $u$ dan de voorkeur?

4a. Aan welke van de volgende kandidaten geeft $u$ de voorkeur?

- Kandidaat A: heeft bovengemiddelde onderzoekskwaliteiten en slechte onderwijskwaliteiten

- Kandidaat B: heeft gemiddelde onderzoekskwaliteiten en gemiddelde onderwijskwaliteiten

4b. Aan welke van de volgende kandidaten geeft $u$ de voorkeur?

a Kandidaat A: heeft uitmuntende onderzoekskwaliteiten en slechte onderwijskwaliteiten

- Kandidaat B: heeft gemiddelde onderzoekskwaliteiten en gemiddelde onderwijskwaliteiten

4a. Aan welke van de volgende kandidaten geeft $u$ de voorkeur?

- Kandidaat A: heeft uitmuntende onderzoekskwaliteiten en matige onderwijskwaliteiten

- Kandidaat B: heeft gemiddelde onderzoekskwaliteiten en gemiddelde onderwijskwaliteiten

4b. Aan welke van de volgende kandidaten geeft $u$ de voorkeur?

a Kandidaat A: heeft uitmuntende onderzoekskwaliteiten en slechte onderwijskwaliteiten

- Kandidaat B: heeft gemiddelde onderzoekskwaliteiten en gemiddelde onderwijskwaliteiten

5. Wanneer er bij een vacature voor een Universitair Docent (UD) twee kandidaten zijn, die op alle andere punten geheel gelijkwaardig zijn, aan welke geeft $u$ dan de voorkeur?

․ Kandidaat A: heeft matige onderzoekskwaliteiten en bovengemiddelde onderwijskwaliteiten

- Kandidaat B: heeft gemiddelde onderzoekskwaliteiten en gemiddelde onderwijskwaliteiten 
5a. Aan welke van de volgende kandidaten geeft $u$ de voorkeur?

- Kandidaat A: heeft slechte onderzoekskwaliteiten en bovengemiddelde onderwijskwaliteiten

- Kandidaat B: heeft gemiddelde onderzoekskwaliteiten en gemiddelde onderwijskwaliteiten

5b. Aan welke van de volgende kandidaten geeft $u$ de voorkeur?

- Kandidaat A: heeft slechte onderzoekskwaliteiten en uitmuntende onderwijskwaliteiten

- Kandidaat B: heeft gemiddelde onderzoekskwaliteiten en gemiddelde onderwijskwaliteiten

5a. Aan welke van de volgende kandidaten geeft $u$ de voorkeur?

- Kandidaat A: heeft matige onderzoekskwaliteiten en uitmuntende onderwijskwaliteiten

- Kandidaat B: heeft gemiddelde onderzoekskwaliteiten en gemiddelde onderwijskwaliteiten

5b. Aan welke van de volgende kandidaten geeft $\mathbf{u}$ de voorkeur?

- Kandidaat A: heeft slechte onderzoekskwaliteiten en uitmuntende onderwijskwaliteiten

- Kandidaat B: heeft gemiddelde onderzoekskwaliteiten en gemiddelde onderwijskwaliteiten

6. Zijn er binnen uw capgroep de laatste twee jaar moeilijk vervulbare vacatures geweest voor wetenschappelijk personeel?

$\square$ ja

nee

6a. Wat was de belangrijkste reden waarom de vacature(s) moeilijk vervulbaar waren?

$\square$ geen sollicitanten

geen geschikte kandidaten

- wel goede kandidaat, maar ons aanbod was niet concurrerend genoeg

6b. Welke aanpassingen hebben er plaatsgevonden om deze moeilijk vervulbare vacatures ingevuld te krijgen? (meerdere antwoorden mogelijk)

a afzwakken van de functie-eisen

口 bieden van een hoger salaris of arbeidsmarkttoeslagen

$\square$ bieden van betere secundaire arbeidsvoorwaarden

口 bieden van meer tijd voor onderzoek

- bieden van meer faciliteiten (reisbudget, sabbatical, e.d.)

- actiever persoonlijk benaderen van mogelijk geschikte kandidaten

口 inschakelen van collegiaal netwerk

- anders, namelijk: ... 
geen aanpassingen, de vacature heeft erg lang open gestaan

geen aanpassingen, de vacature staat nog steeds open

\section{Hoeveel medewerkers hebben in 2004 uw capgroep verlaten?}

\section{Capgroep}

Sommige faculteiten spreken van departementen; indien u leiding geeft aan een sectie binnen een bepaalde capgroep, verzoeken wij u telkens uit te gaan van deze sectie.
- $\quad$ AIO's/promovendi
... (aantal personen)

- $\quad$ AIO's/Promovendi

...

Hiermee bedoelen we AIO's of andere promovendi die voor of direct na hun promotie elders zijn gaan werken.

- $\quad$ overig wetenschappelijk personeel

- $\mathrm{OBP}$

\section{Wat zijn deze mensen gaan doen?}

(Vermeld telkens het aantal personen)

- $\mathrm{AIO}$ 's/Promovendi

AIO's Overig WP OBP

Hiermee bedoelen we AIO's of andere promovendi

die voor of direct na hun promotie elders zijn gaan werken.

- functie bij andere universiteit

- functie bij andere organisatie

- andere functie binnen de faculteit

- andere functie binnen de UM

- gestopt met werken / overleden

- werkloos

9a. Is er in uw capgroep in 2004 sprake geweest van personeelsverloop van WP'ers vanwege een gebrek aan doorgroeimogelijkheden?

a nee

口 ja, met name voor AIO's

口 ja, met name voor post-docs

a ja, met name voor

$\square$ ja, zowel voor junior als senior medewerkers

9b. Was dit personeelsverloop in sommige gevallen voor uw capgroep ongewenst?

a nee

口 ja

\section{Personeelsontwikkeling}

Io. Vindt $u$ het belangrijk om de ontwikkeling van uw WP te stimuleren?

$\square$ nee 
口 ja, maar alleen voor AIO's/promovendi

$\square$ ja, maar alleen wanneer er op dit punt problemen zijn

a ja, altijd

II. Welke instrumenten vindt $u$ belangrijk voor de ontwikkeling van het WP in uw capgroep? (meerdere antwoorden mogelijk)

a functioneringsgesprekken

$\square$ beoordelingsgesprekken

a persoonlijke ontwikkelingsplannen (POP's)

口 coaching van individuele medewerkers

Coaching:

Hieronder verstaan we zowel de coaching van minder ervaren medewerkers door ervaren medewerkers, als de coaching door externen.

b bij- en nascholing

a deelname aan wetenschappelijke congressen

a presentaties op interne seminars

a stimuleren internationale uitwisseling

口 prestatiebeloning op individueel niveau

Prestatiebeloning:

Hierbij bedoelen we alle mogelijke vormen van prestatiebeloning, zoals gratificaties, extra periodieken, bonussen, e.d.

a prestatiebeloning op teamniveau

Prestatiebeloning:

Hierbij bedoelen we alle mogelijke vormen van prestatiebeloning, zoals gratificaties, extra periodieken, bonussen, e.d.

- anders, namelijk: ....

I2. Welke van de onderstaande instrumenten worden momenteel binnen uw capgroep ingezet voor het wetenschappelijk personeel?

voor alle WP'ers - voor de meeste WP'ers - voor enkele WP'ers - niet

- Functioneringsgesprekken

- Beoordelingsgesprekken

- Persoonlijke ontwikkelingsplannen (POP's)

- Coaching van individuele medewerkers

Coaching:

Hieronder verstaan we zowel de coaching van minder ervaren medewerkers door ervaren medewerkers, als de coaching door externen.

- Bij- en nascholing

- Deelname aan wetenschappelijke congressen

- Presentaties op interne seminars

- Stimuleren internationale uitwisseling

- Prestatiebeloning op individueel niveau 


\section{Prestatiebeloning:}

Hierbij bedoelen we alle mogelijke vormen van prestatiebeloning, zoals gratificaties, extra periodieken, bonussen, e.d.

- Prestatiebeloning op teamniveau

\section{Prestatiebeloning:}

Hierbij bedoelen we alle mogelijke vormen van prestatiebeloning, zoals gratificaties, extra periodieken, bonussen, e.d.

- $\quad$ anders, namelijk:...

13. Wat is de normale frequentie die u hanteert voor functioneringsgesprekken met WP'ers?

$\square$ jaarlijks (of vaker)

口 tweejaarlijks

a minder dan één keer in de twee jaar

I4. Wordt er een verslag gemaakt van functioneringsgesprekken?

a nee

口 ja, altijd

a meestal

a soms

I5. Op welke terreinen worden er voor individuele WP'ers binnen uw capgroep concrete prestatiedoelen geformuleerd? (meerdere antwoorden mogelijk)

o onderwijs

口 onderzoek

口 anders, namelijk: ...

$\square$ geen

I5a. Voor welke categorieën WP'ers worden deze prestatiedoelen geformuleerd? (meerdere antwoorden mogelijk)

a hoogleraren

u UHD's

a UD's

- $\mathrm{AIO}$ 's/promovendi

a anderen, namelijk: ...

I6. Hoeveel medewerkers hebben het afgelopen jaar een of meerdere papers gepresenteerd op een internationaal congres?

(Als $u$ het niet precies weet, wilt $u$ dan s.v.p. een schatting geven)

... (aantal personen) 


\section{Opleidingen}

17. Hoeveel WP'ers hebben in 2004 minimaal één interne of externe cursus of training gevolgd?

(Als $u$ het niet precies weet, wilt $u$ dan s.v.p. een schatting geven)

... (aantal personen)

I8. Welk soort cursussen of trainingen vindt $u$ belangrijk voor het wetenschappelijk personeel in uw capgroep?

voor alle WP'ers - voor de meeste WP'ers - voor enkele WP'ers - niet belangrijk

- cursussen op het vakgebied van de medewerker

- onderwijsvaardigheden

- managementtraining

- communicatieve vaardigheden

- $\quad$ IT vaardigheden t.b.v. onderwijs

- IT vaardigheden (algemeen)

- Engels

- $\quad$ milieu en arbeidsomstandigheden op de werkplek

- overig, namelijk:...

19. Welk soort cursussen of trainingen hebben WP'ers in uw capgroep het afgelopen jaar het meest gevolgd?

(Noem maximaal 5 soorten)

- cursus in netwerk van promovendi

a andere cursussen op het vakgebied van de medewerker

口 onderwijsvaardigheden

a managementtraining

a communicatieve vaardigheden

口 IT vaardigheden t.b.v. onderwijs

- IT vaardigheden (algemeen)

¿ Engels

a milieu en arbeidsomstandigheden op de werkplek

口 overig, namelijk: ...

19a. Zojuist heeft $u$ aangegeven welke cursussen of trainingen WP'ers in uw capgroep het afgelopen jaar gevolgd hebben. Hieronder worden deze cursussen of trainingen nogmaals weergegeven. Kunt u deze cursussen of trainingen rangschikken naar mate van belangrijkheid (waarbij I=meest belangrijk)?

口 cursus in netwerk van promovendi

$\square$ andere cursussen op het vakgebied van de medewerker

$\square$ onderwijsvaardigheden

a managementtraining

口 communicatieve vaardigheden 


\section{$\underline{\text { Kwaliteiten }}$}

20. Hoe beoordeelt $u$ de kwaliteiten van uw capgroep?

(Geeft $\mathbf{u}$ hierbij telkens een rapportcijfer van I-IO)

Algehele kwaliteit

Cijfer:

Vakspecifieke kennis

Onderzoekskwaliteiten

Onderwijskwaliteiten

Werken in teamverband

IT vaardigheden

Communicatieve vaardigheden

Beheersing Engels

Flexibiliteit

Initiatief

Leervermogen

Ondersteunende rol van het OBP

\section{Belemmeringen}

2I. Ervaart u belemmeringen bij het personeelsbeleid dat u graag wilt voeren?

口 nee

口 ja, namelijk: ...

\section{Persoonlijk}

22. Vanaf wanneer bent $\mathbf{u}$ beherend baas van uw capgroep?

... (jaar)

23. Hoeveel jaar ervaring heeft $u$ met het leiding geven aan WP'ers?

... (jaar)

24. Wat is uw geboortejaar?

I9 ...

25. Ten slotte zouden wij $\mathbf{u}$ graag willen vragen om een beeld te geven van uw eigen kwaliteiten op een aantal terreinen, in vergelijking met collega's in vergelijkbare posities.

$$
\text { Veel slechter - - - Veel beter }
$$

- In onderhandelingen streef ik naar "win-win" overeenkomsten

- Ik draag visie en strategie op een consistente wijze uit

- Ik creëer draagvlak voor mijn beslissingen

- $\quad$ Ik bereid me voor op vergaderingen en gesprekken 
- Ik ben beschikbaar en luister naar anderen

- Ik uit waardering voor successen en inspanningen

- Ik kan nee zeggen

- Ik stimuleer mijn medewerkers en collega's zich beroepsmatig te ontwikkelen

Veel minder - - - Veel meer

- Ik ben gericht op het versterken van de onderzoeksreputatie van mijn capgroep

- Ik stimuleer discussies over het onderzoek

- Ik ben gericht op het versterken van de onderwijsreputatie van mijn capgroep 


\section{B. VRAGENLIJST DIENSTVERLENERS Algemeen}

I. Hoeveel medewerkers zijn er momenteel werkzaam bij het bureau, de dienst of het instituut dat $\mathbf{u}$ aanstuurt? (inclusief tijdelijk personeel)

Het bureau, de dienst of het instituut:

Hiermee bedoelen we de organisatie-eenheid waaraan u direct of indirect leiding geeft.

- $\quad$ wetenschappelijk personeel ... (aantal personen)

- OBP ...

\section{Selectie van nieuw personeel}

Via een aantal vragen willen we bij $\mathrm{u}$ aftasten hoe $\mathrm{u}$ bij het aantrekken van een nieuwe medewerker voor een functie die belangrijk is voor de kwaliteit van de dienstverlening van uw bureau of dienst, vakspecifieke kwaliteiten afweegt tegen communicatieve kwaliteiten.

Om hiervan een goed totaalbeeld te krijgen is het belangrijk dat u iedere keer een kandidaat kiest, ook al zou u liever geen van beide kandidaten willen aannemen.

2. Wanneer er bij een vacature voor een functie die belangrijk is voor de kwaliteit van de dienstverlening van uw bureau twee kandidaten zijn, die op alle andere punten geheel gelijkwaardig zijn, aan welke geeft $\mathbf{u}$ dan de voorkeur?

․ Kandidaat A: heeft bovengemiddelde vakspecifieke kwaliteiten en matige communicatieve kwaliteiten

- Kandidaat B: heeft gemiddelde vakspecifieke kwaliteiten en gemiddelde communicatieve kwaliteiten

2a. Aan welke van de volgende kandidaten geeft $u$ de voorkeur?

- Kandidaat A: heeft bovengemiddelde vakspecifieke kwaliteiten en slechte communicatieve kwaliteiten

Kandidaat B: heeft gemiddelde vakspecifieke kwaliteiten en gemiddelde communicatieve kwaliteiten

2b. Aan welke van de volgende kandidaten geeft $\mathbf{u}$ de voorkeur?

- Kandidaat A: heeft uitmuntende vakspecifieke kwaliteiten en slechte communicatieve kwaliteiten

- Kandidaat B: heeft gemiddelde vakspecifieke kwaliteiten en gemiddelde communicatieve kwaliteiten

2a. Aan welke van de volgende kandidaten geeft $u$ de voorkeur?

- Kandidaat A: heeft uitmuntende vakspecifieke kwaliteiten en matige communicatieve kwaliteiten

- Kandidaat B: heeft gemiddelde vakspecifieke kwaliteiten en gemiddelde communicatieve kwaliteiten 
2b. Aan welke van de volgende kandidaten geeft $\mathbf{u}$ de voorkeur?

- Kandidaat A: heeft uitmuntende vakspecifieke kwaliteiten en slechte communicatieve kwaliteiten

- Kandidaat B: heeft gemiddelde vakspecifieke kwaliteiten en gemiddelde communicatieve kwaliteiten

3. Wanneer er bij een vacature voor een functie die belangrijk is voor de kwaliteit van de dienstverlening van uw bureau twee kandidaten zijn, die op alle andere punten geheel gelijkwaardig zijn, aan welke geeft $\mathbf{u}$ dan de voorkeur?

- Kandidaat A: heeft matige vakspecifieke kwaliteiten en bovengemiddelde communicatieve kwaliteiten

- Kandidaat B: heeft gemiddelde vakspecifieke kwaliteiten en gemiddelde communicatieve kwaliteiten

3a. Aan welke van de volgende kandidaten geeft $u$ de voorkeur?

- Kandidaat A: heeft slechte vakspecifieke kwaliteiten en bovengemiddelde communicatieve kwaliteiten

․ Kandidaat B: heeft gemiddelde vakspecifieke kwaliteiten en gemiddelde communicatieve kwaliteiten

3b. Aan welke van de volgende kandidaten geeft u de voorkeur?

- Kandidaat A: heeft slechte vakspecifieke kwaliteiten en uitmuntende communicatieve kwaliteiten

- Kandidaat B: heeft gemiddelde vakspecifieke kwaliteiten en gemiddelde communicatieve kwaliteiten

3a. Aan welke van de volgende kandidaten geeft $u$ de voorkeur?

- Kandidaat A: heeft matige vakspecifieke kwaliteiten en uitmuntende communicatieve kwaliteiten

- Kandidaat B: heeft gemiddelde vakspecifieke kwaliteiten en gemiddelde communicatieve kwaliteiten

3b. Aan welke van de volgende kandidaten geeft u de voorkeur?

- Kandidaat A: heeft slechte vakspecifieke kwaliteiten en uitmuntende communicatieve kwaliteiten

․ Kandidaat B: heeft gemiddelde vakspecifieke kwaliteiten en gemiddelde communicatieve kwaliteiten

4. Zijn er binnen uw bureau of dienst de laatste twee jaar moeilijk vervulbare vacatures geweest?

$\square$ ja

口 nee 
4a. Wat was de belangrijkste reden waarom de vacature(s) moeilijk vervulbaar waren? (meerdere antwoorden mogelijk)

$\checkmark$ geen sollicitanten

a geen geschikte kandidaten

․ wel goede kandidaat, maar ons aanbod was niet concurrerend genoeg

4b. Welke aanpassingen hebben er plaatsgevonden om deze moeilijk vervulbare vacatures ingevuld te krijgen? (meerdere antwoorden mogelijk)

口 afzwakken van de functie-eisen

- bieden van een hoger salaris of arbeidsmarkttoeslagen

- bieden van betere secundaire arbeidsvoorwaarden

- actiever persoonlijk benaderen van mogelijk geschikte kandidaten

口 inschakelen van commercieel wervingsbureau

a anders, namelijk:

- geen aanpassingen, de vacature heeft erg lang open gestaan

a geen aanpassingen, de vacature staat nog steeds open

\section{Personeelsverloop}

5. Hoeveel medewerkers hebben in 2004 uw bureau of dienst verlaten?

- wetenschappelijk personeel ... (aantal personen)

- OBP ...

\section{Wat zijn deze mensen gaan doen?}

(Vermeld telkens het aantal personen) Aantal:

- functie bij andere universiteit

- functie bij andere organisatie

- andere functie binnen de dienst of faculteit

- andere functie binnen de UM

- gestopt met werken / overleden

- werkloos

7a. Is er bij uw bureau of dienst in 2004 sprake geweest van personeelsverloop vanwege een gebrek aan doorgroeimogelijkheden?

a nee

口 ja, regelmatig

口 ja, in een enkel geval

7b. Was dit personeelsverloop (in sommige gevallen) voor uw bureau of dienst ongewenst?

$\square$ nee

$\square$ ja 


\section{Personeelsontwikkeling}

8. Vindt $u$ het belangrijk om de ontwikkeling van uw medewerkers te stimuleren?

$\square$ nee

口 ja, maar alleen bij onervaren personeel

$\square$ ja, maar alleen wanneer er op dit punt problemen zijn

a ja, altijd

9. Welke instrumenten vindt u belangrijk voor de ontwikkeling van de medewerkers van uw bureau of dienst? (meerdere antwoorden mogelijk)

․ functioneringsgesprekken

口 beoordelingsgesprekken

a persoonlijke ontwikkelingsplannen (POP's)

口 coaching van individuele medewerkers

Coaching:

Hieronder verstaan we zowel de coaching van minder ervaren medewerkers door ervaren medewerkers, als de coaching door externen.

口 bij- en nascholingsbeleid

$\square$ prestatiebeloning op individueel niveau

Prestatiebeloning:

Hierbij bedoelen we alle mogelijke vormen van prestatiebeloning, zoals gratificaties, extra periodieken, bonussen, e.d.

口 prestatiebeloning op teamniveau

Prestatiebeloning:

Hierbij bedoelen we alle mogelijke vormen van prestatiebeloning, zoals gratificaties, extra periodieken, bonussen, e.d.

口 anders, namelijk: ...

Io. In welke mate worden de onderstaande instrumenten momenteel binnen uw bureau of dienst ingezet?

voor alle medewerkers - voor de meeste medewerkers - voor enkele medewerkers - niet

- Functioneringsgesprekken

- Beoordelingsgesprekken

- Persoonlijke ontwikkelingsplannen (POP's)

- Coaching van individuele medewerkers Coaching:

Hieronder verstaan we zowel de coaching van minder ervaren medewerkers door ervaren medewerkers, als de coaching door externen.

- Bij-en nascholing

- Prestatiebeloning op individueel niveau 
Prestatiebeloning:

Hierbij bedoelen we alle mogelijke vormen van prestatiebeloning, zoals gratificaties, extra periodieken, bonussen, e.d.

- Prestatiebeloning op teamniveau

Prestatiebeloning:

Hierbij bedoelen we alle mogelijke vormen van prestatiebeloning, zoals gratificaties, extra periodieken, bonussen, e.d.

- anders, namelijk:...

II. Wat is de normale frequentie die $u$ hanteert voor het voeren van functioneringsgesprekken?

口 jaarlijks (of vaker)

口 tweejaarlijks

a minder dan één keer in de twee jaar

I2. Wordt er een verslag gemaakt van functioneringsgesprekken?

$\square$ nee

a ja, altijd

a meestal

a soms

13. Zijn er voor individuele medewerkers in uw bureau of dienst specifieke prestatiedoelen geformuleerd?

$\square$ nee

口 ja, voor enkele medewerkers

口 ja, voor de meeste medewerkers

口 ja, voor alle medewerkers

\section{Opleidingen}

I4. Hoeveel medewerkers hebben in 2004 minimaal één interne of externe cursus of training gevolgd?

(Als $u$ het niet precies weet, wilt $u$ dan s.v.p. een schatting geven)

... (aantal personen)

15. Welk soort cursussen vindt $\mathbf{u}$ belangrijk voor uw medewerkers?

voor alle medewerkers - voor de meeste medewerkers - voor enkele medewerkers - niet belangrijk

- cursussen op het vakgebied van de medewerker

- onderwijsvaardigheden

- managementtraining

- communicatieve vaardigheden

- IT vaardigheden

- commerciële vaardigheden 
- Engels

- milieu en arbeidsomstandigheden op de werkplek

- overig, namelijk:...

I6. Welk soort cursussen of trainingen hebben uw medewerkers het afgelopen jaar het meest gevolgd?

(Noem maximaal 5 soorten)

a cursussen op het vakgebied van de medewerker

口 onderwijsvaardigheden

a managementtraining

a communicatieve vaardigheden

口 IT vaardigheden

口 commerciële vaardigheden

ㅁ. Engels

a milieu en arbeidsomstandigheden op de werkplek

口 overig, namelijk: ...

17. Zojuist heeft $u$ aangegeven welke cursussen of trainingen uw medewerkers het afgelopen jaar gevolgd hebben. Hieronder worden deze cursussen of trainingen nogmaals weergegeven. Kunt u deze cursussen of trainingen rangschikken naar mate van belangrijkheid (waarbij I=meest belangrijk)?

cursussen op het vakgebied van de medewerker

$\square$ onderwijsvaardigheden

a communicatieve vaardigheden

口 IT vaardigheden

口 commerciële vaardigheden

\section{$\underline{\text { Kwaliteiten }}$}

17. Hoe beoordeelt u de kwaliteiten van de medewerkers van uw afdeling? (Geeft $\mathbf{u}$ hierbij telkens een rapportcijfer van I-IO)

- Algehele kwaliteit

Cijfer:

- Vakspecifieke kennis

口 Onderzoekskwaliteiten

- Onderwijskwaliteiten

口 Zelfstandig werken

口 Werken in teamverband

口 IT vaardigheden

- Probleemoplossend vermogen

口 Procesgericht werken

a Plannen en organiseren

- Communicatieve vaardigheden

$\ldots$
$\ldots$
$\ldots$
$\ldots$
$\ldots$
$\ldots$
$\ldots$
$\ldots$
$\ldots$
$\ldots$
$\ldots$


․ Commerciële vaardigheden

ㅁ Beheersing Engels

- Flexibiliteit

- Initiatief

L Leervermogen

\section{Belemmeringen}

I8. Ervaart $\mathbf{u}$ belemmeringen bij het personeelsbeleid dat $\mathbf{u}$ graag wilt voeren?

nee

a ja, namelijk:...

\section{Persoonlijk}

19. Vanaf wanneer bent $u$ beherend baas van uw bureau of dienst? ... (jaar)

20. Hoeveel jaar ervaring heeft $u$ in leidinggevende functies? ... (jaar)

\section{I. Wat is uw geboortejaar?}

I9..

22. Ten slotte zouden wij u graag willen vragen om een beeld te geven van uw eigen kwaliteiten op een aantal terreinen, in vergelijking met collega's in vergelijkbare posities.

$$
\text { Veel slechter - - - Veel beter }
$$

- In onderhandelingen streef ik naar "win-win" overeenkomsten

- Ik draag visie en strategie op een consistente wijze uit

- Ik creëer draagvlak voor mijn beslissingen

- Ik bereid me voor op vergaderingen en gesprekken

- Ik ben beschikbaar en luister naar anderen

- Ik uit waardering voor successen en inspanningen

- Ik kan nee zeggen

- Ik stimuleer mijn medewerkers en collega's zich beroepsmatig te ontwikkelen 